\title{
A LUZ DO DIA NO PENSAMENTO E PRÁTICA PROJETUAL DE ARQUITETOS EGRESSOS
} DA FAUUSP NO PERÍODO DE 1985 A 2005

\begin{abstract}
Dissertação apresentada à Faculdade de Arquitetura e Urbanismo da Universidade de São Paulo para obtenção do título de Mestre em Arquitetura e Urbanismo
\end{abstract}

Área de Concentração: Tecnologia da Arquitetura

Orientador: Prof. Dr. Paulo Sergio Scarazzato

EXEMPLAR REVISADO E ALTERADO EM RELAÇÃO À VERSÃO ORIGINAL, SOB RESPONSABILIDADE DO AUTOR E ANUÊNCIA DO ORIENTADOR.

O original se encontra disponível na sede do programa.

São Paulo, 08 de julho 2012.

\section{SÃO PAULO}


AUTORIZO A REPRODUÇÃO E DIVULGAÇÃO TOTAL OU PARCIAL DESTE TRABALHO, POR QUALQUER MEIO CONVENCIONAL OU ELETRÔNICO, PARA FINS DE ESTUDO E PESQUISA, DESDE QUE CITADA A FONTE.

E-MAIL AUTORA: acsl@mps.com.br

E-MAIL ORIENTADOR:

Lacerda, Ana Cristina da Silva de

L131L A luz do dia no pensamento e prática projetual de arquitetos egressos da FAUUSP no período de 1985 a 2005 / Ana Cristina da Silva de Lacerda. --São Paulo, 2012. 148 p. : il.

Dissertação (Mestrado - Área de Concentração: Tecnologia da Arquitetura) - FAUUSP.

Orientador: Paulo Sergio Scarazzato

1.Luz 2.Iluminação natural 3.Projeto de arquitetura (Ensino Processos) I.Título

CDU 628.92 


\section{A LUZ DO DIA NO PENSAMENTO E PRÁTICA PROJETUAL DE ARQUITETOS EGRESSOS DA FAUUSP NO PERÍODO DE 1985 A 2005}

Dissertação apresentada à Faculdade de Arquitetura e Urbanismo da Universidade de São Paulo para obtenção do título de Mestre em Arquitetura e Urbanismo

Área de Concentração: Tecnologia da Arquitetura

Orientador: Prof. Dr. Paulo Sergio Scarazzato

\section{BANCA EXAMINADORA:}

Orientador: Prof. Dr. Paulo Sergio Scarazzato

Profa. Dra. Doris C.C. Knatz Kowaltowski

Prof. Dr. Carlos Augusto Mattei Faggin 
À Sofia 
Ao meu orientador Prof. Dr. Paulo Sergio Scarazzato por todo o ensinamento, valiosa orientação, dedicação, competência, paciência, intensa participação e apoio incondicional durante todo o trabalho.

Ao Prof. Dr. Carlos Augusto Mattei Faggin e ao Prof. Artur Simões Rozestraten pelas pertinentes sugestões e comentários feitos por ocasião da qualificação, os quais procurei incorporar ao trabalho.

Ao Prof. Dr. Lucio Gomes Machado e Prof. Dr. Carlos Augusto Mattei Faggin pelo incentivo e reflexões esclarecedoras acerca da minha pesquisa.

Ao Prof. Dr. Nestor Goulart Reis Filho que atenciosamente compartilhou suas idéias em uma entrevista.

Ao Prof. Ricardo Machado Pereira e Prof. José Marcos Novak pelo apoio e motivação para seguir a vida acadêmica.

Aos arquitetos Álvaro Puntoni, Luciano Margotto Soares, Vinícius Andrade, Marcelo Morettin, Caio Faggin e Lourenço Gimenez que atenciosamente colaboraram com a minha pesquisa, compartilhando suas idéias e produções.

A todos os meus colegas da FAUUSP que contribuíram de diferentes maneiras para a realização dessa dissertação. De todos, com igual importância, tenho momentos gravados em minha memória e só não os nomeio para evitar cometer injustiças.

Aos funcionários da Secretaria de Pós-Graduação e das Bibliotecas da FAUUSP, agradeço pela presteza e bom humor.

Aos funcionários do Departamento de Tecnologia da FAUUSP pela constante simpatia e disposição.

Ao arquiteto Jahyr Fonseca Filho pelos ensinamentos ao longo da minha vida profissional.

A todos os meus amigos que sempre me apoiaram ao longo desses anos e que pacientemente entenderam as minhas ausências.

Aos meus pais Pedro e Pureza pelo apoio, incentivo e amor incondicional.

E especialmente ao Sergio, Carolina, Rafael, Elton, João e Sofia por compartilharem comigo este caminho. 
LACERDA, A. C. S. A luz do dia no pensamento e prática projetual de arquitetos egressos da FAUUSP no período de 1985 a 2005. 2012. 148 p. Dissertação (Mestrado) - Faculdade de Arquitetura e Urbanismo, Universidade de São Paulo, São Paulo, 2012.

\section{RESUMO}

A luz é necessária para que a matéria se manifeste e se torne visível. A possibilidade da percepção do espaço e do vazio, da visualização de um componente, de um conjunto de formas ou do todo, onde a arquitetura se apresenta e se revela, dáse em função da existência do fenômeno luz. A arquitetura dispõe elementos no espaço para captar, refletir, diluir e também emitir a luz. O uso da luz do dia como diretriz de projeto requer uma postura crítica que valorize igualmente uma relação íntima entre aspectos poéticos e aspectos técnicos; tendo como referência o contexto histórico-cultural e as condições ambientais do lugar, as necessidades programáticas, as técnicas construtivas disponíveis e, principalmente, os usuários. Pretende-se fazer uma reflexão sobre o processo de incorporação da luz do dia no processo criativo de arquitetos egressos da FAUUSP entre os anos de 1985 e 2005 que passaram a ocupar lugar de destaque no panorama da arquitetura contemporânea brasileira. Devido ao recorte cronológico estabelecido, foram selecionados para estudo os arquitetos Álvaro Puntoni, Luciano Margotto Soares, Vinícius Andrade, Marcelo Morettin, Caio Faggin, Fernando Forte, Lourenço Gimenes e Rodrigo Marcondes Ferraz. Cada profissional ou escritório de arquitetura que esses arquitetos integram como titulares tiveram duas obras analisadas relativamente à incorporação da luz do dia enquanto elemento de composição na arquitetura.

Palavras-chave: Luz. Iluminação natural. Elemento de composição. 
LACERDA, A. C. S. Daylight in the thinking and design practice of architects who graduated at FAUSP between 1985 to 2005. 2012. 148 p. Dissertação (Mestrado) Faculdade de Arquitetura e Urbanismo, Universidade de São Paulo, São Paulo, 2012.

\section{ABSTRACT}

Light is necessary for the substance to manifest itself and become visible. The possibility of space and emptiness perception, the ability to see a certain component, a set of forms or its combination, where architecture is presented and reveals itself, is due to the existence of the phenomenon known as light. Architecture has elements to capture, reflect, dilute and also emit light. The use of daylight as a guideline for project requires a critical posture that values an intimate relationship between poetic and technical aspects. Concerning also historical-cultural reference and the environmental conditions of the place, as well as programmatic requirements, construction techniques available and especially its users. It is intended to reflect on the process of incorporation of daylight in the creative process of architects who graduated from FAUUSP between the years of 1985 and 2005 that came to occupy a prominent place in the panorama of contemporary Brazilian architecture. Due to the chronological cut set were selected for study the architects Álvaro Puntoni, Luciano Margotto Soares, Vinícius Andrade, Marcelo Morettin, Caio Faggin, Fernando Forte, Lourenço Gimenes e Rodrigo Marcondes Ferraz. Each professional or architectural firm that architects integrate had two works analyzed for incorporation of daylight as an element of composition in architecture.

Keywords: Light. Natural lighting. Element of composition in architecture. 


\section{Capitulo I}

O fenômeno da luz

1.1. A luz do dia e a arquitetura 21

1.2. Luz e lugar 24

1.3. Luz e clima 25

1.4. Luz e tempo 26

1.5. Simbologia da luz 26

\section{Capitulo II}

A visão da luz do dia para o arquiteto Álvaro Puntoni 31

2.1. Edifício I 36

2.1.2. Localização 36

2.1.3. Equipe técnica 37

2.1.4. Breve histórico 38

2.1.5. Estudo analítico do edifício: a implantação 38

2.1.6. Composição espacial 39

2.1.7. Materiais e cores $\quad 41$

2.1.8. Iluminação natural: aspectos funcionais e subjetivos 42

2.2. Edifício II 47

2.2.1. Localização $\quad 47$

2.2.2. Equipe técnica 49

2.2.3. Breve histórico 50

2.2.4. Estudo analítico do edifício: a implantação 50

2.2.5. Composição espacial 51

2.2.6. Materiais e cores 53

2.2.7. Iluminação natural: aspectos funcionais e subjetivos 55

Capitulo III

A visão da luz do dia para o arquiteto Luciano Margotto Soares 62

$\begin{array}{ll}\text { 3.1. Edifício I } & 67\end{array}$

3.1.1. Localização $\quad 67$ 
3.1.3. Estudo analítico do edifício: a implantação 68

3.1.4. Composição espacial $\quad 69$

3.1.5. Materiais e cores 70

3.1.6. Iluminação natural: aspectos funcionais e subjetivos 70

3.2. Edifício II 73

3.2.1. Localização

3.2.2. Equipe técnica $\quad 74$

3.2.3. Breve histórico 74

3.2.4. Estudo analítico do edifício: a implantação e composição espacial 74

3.2.5. Materiais e cores

3.2.6. Iluminação natural: aspectos funcionais e subjetivos 79

\section{Capitulo IV}

A visão da luz do dia para os arquitetos do escritório paulistano Andrade Morettin $\quad 81$

4.1. Edifício I 85

4.1.1. Localização

4.1.2. Equipe técnica 86

4.1.3. Breve histórico 87

4.1.4. Estudo analítico do edifício: a implantação 87

4.1.5. Composição espacial 88

4.1.6. Materiais e cores $\quad 90$

4.1.7. Iluminação natural: aspectos funcionais e subjetivos 91

4.2. Edifício II 95

4.2.1. Localização $\quad 95$

4.2.2. Equipe técnica 96

4.2.3. Breve histórico 96

4.2.4. Estudo analítico do edifício: a implantação 97

4.2.5. Composição espacial 98

4.2.6. Materiais e cores $\quad 99$

4.2.7. Iluminação natural: aspectos funcionais e subjetivos 100 


\section{Capitulo V}

A visão da luz do dia para o arquiteto Caio Faggin

103

$\begin{array}{ll}\text { 5.1. Edifício I } & 105\end{array}$

5.1.1. Localização 105

5.1.2. Equipe técnica 106

5.1.3. Breve histórico 106

5.1.4. Estudo analítico do edifício: a implantação 106

5.1.5. Composição espacial 107

$\begin{array}{ll}\text { 5.1.6. Materiais e cores } & 109\end{array}$

5.1.7. Iluminação natural: aspectos funcionais e subjetivos 110

5.2. Edifício II 113

5.2.1. Localização 113

$\begin{array}{ll}\text { 5.2.2. Breve histórico } & 113\end{array}$

5.2.3. Estudo analítico do edifício: a implantação 114

5.2.4. Composição espacial 115

$\begin{array}{ll}\text { 5.2.5. Materiais e cores } & 117\end{array}$

5.2.6. Iluminação natural: aspectos funcionais e subjetivos 118

\section{Capitulo VI}

A visão da luz do dia para os arquitetos do escritório paulistano FGMF 120

6.1. Edifício I 123

6.1.1. Localização 123

6.1.2. Equipe técnica 124

6.1.3. Breve histórico $\quad 124$

6.1.4. Estudo analítico do edifício: a implantação 125

6.1.5. Composição espacial 125

$\begin{array}{ll}\text { 6.1.6. Materiais e cores } & 127\end{array}$

6.1.7. Iluminação natural: aspectos funcionais e subjetivos 128

$\begin{array}{ll}\text { 6.2. Edifício II } & 131\end{array}$

6.2.1. Localização 131

6.2.2. Equipe técnica 132

6.2.3. Breve histórico 133 
6.2.4. Estudo analítico do edifício: a implantação

6.2.5. Composição espacial

134

6.2.6. Iluminação natural: aspectos funcionais e subjetivos 136

Considerações finais 138

Apêndice

141

Referências 
Fig. 1 Composição do espectro solar 19

Fig. 2 Igreja de San Lorenzo - Turin $\quad 21$

Fig. 3 Mesquita Azul - Istambul 21

Fig. 4 Pantheon, Roma $\quad 22$

Fig. 5 Le Corbusier, Notre Dame du Haut, Ronchamp 22

Fig. 6 Louis Kahn, Kimbell Art Museum, Texas 22

Fig. 7 Peter Zumthor, Termas de Vals, Suíça 23

Fig. 8 Forma e caráter 23

Fig. 9 Tromso, Noruega, 8:00h, 12:00h e 16:00h - lat.6939' N - long.18인 L 25

Fig. 10 Church on the Water,Tomamu, Japan.Tadao Ando 26

Fig. 11 Le Corbusier, Convento de La Tourette 29

Fig. 12 Modelo físico 33

Fig. 13 Museu Rufino Tamayo, arquiteto Abraham Zabludovsky $\quad 35$

Fig. 14 El Colegio de México, arquiteto Abraham Zabludovsky $\quad 35$

Fig. 15 Residência no Morro do Querosene 36

Fig. 16 Situação Residência no Morro do Querosene 37

Fig. 17 Situação Residência no Morro do Querosene 37

Fig. 18 Modelo físico residência no Morro do Querosene 38

Fig. 19 Corte Longitudinal 39

Fig. 20 Planta pavimento térreo $\quad 40$

Fig. 21 Planta pavimento intermediário $\quad 40$

Fig. 22 Planta pavimento superior $\quad 41$

Fig. 23 Residência no Morro do Querosene $\quad 41$

Fig. 24 Residência no Morro do Querosene $\quad 43$

Fig. 25 Residência no Morro do Querosene 43

Fig. 26 Residência no Morro do Querosene 43

Fig. 27 Planta pavimento térreo - aberturas 44

Fig. 28 Planta pavimento intermediário - aberturas 44

Fig. 29 Planta pavimento superior - aberturas 44

Fig. 30 Corte esquemático $\quad 45$

Fig. 31 Residência no Morro do Querosene $\quad 46$

Fig. 32 Residência no Morro do Querosene 46

Fig. 33 Edifício Institucional em Brasília $\quad 47$

Fig. 34 Situação Edifício SEBRAE em Brasília $\quad 48$

Fig. 35 Situação Edifício SEBRAE em Brasília $\quad 48$

Fig. 36 Situação Edifício SEBRAE em Brasília $\quad 49$

Fig. 37 Implantação Edifício SEBRAE em Brasília 51

Fig. 38 Implantação Edifício SEBRAE em Brasília $\quad 51$

Fig. 39 Perspectiva nível térreo inferior Edifício SEBRAE em Brasília 52

Fig. 40 Perspectiva nível térreo superior Edifício SEBRAE em Brasília 52

Fig. 41 Perspectiva Edifício SEBRAE em Brasília 53 
Fig. 42 Edifício SEBRAE em Brasília 54

Fig. 43 Edifício SEBRAE em Brasília 55

Fig. 44 Corte esquemático Edifício SEBRAE em Brasília 55

Fig. 45 Corte esquemático Edifício SEBRAE em Brasília 56

Fig. 46 Subsolo 1 e 2 Edifício SEBRAE em Brasília 56

Fig. 47 Térreo inferior Edifício SEBRAE em Brasília 57

Fig. 48 Edifício SEBRAE em Brasília 58

Fig. 49 Edifício SEBRAE em Brasília 58

Fig. 50 Área administrativa Edifício SEBRAE em Brasília 59

Fig. 51 Edifício SEBRAE em Brasília 60

Fig. 52 Edifício SEBRAE em Brasília 61

Fig. 53 Situação Centro comercial e de serviços 67

Fig. 54 Situação Centro comercial e de serviços 68

Fig. 55 Centro comercial e de serviços $\quad 68$

Fig. 56 Centro comercial e de serviços 69

Fig. 57 FAAP - Fundação Armando Álvares Penteado 69

Fig. 58 Centro comercial e de serviços $\quad 69$

Fig. 59 Centro comercial e de serviços $\quad 71$

Fig. 60 Centro comercial e de serviços $\quad 71$

Fig. 61 Centro comercial e de serviços $\quad 72$

Fig. 62 Centro comercial e de serviços $\quad 72$

Fig. 63 Centro comercial e de serviços $\quad 72$

Fig. 64 Situação Terminal da Lapa 73

Fig. 65 Maquete Terminal da Lapa $\quad 73$

Fig. 66 Planta Terminal da Lapa

Fig. 67 Planta Terminal da Lapa 76

Fig. 68 Corte esquemático Terminal da Lapa $\quad 77$

Fig. 69 Terminal da Lapa $\quad 78$

Fig. 70 Terminal da Lapa $\quad 78$

Fig. 71 Terminal da Lapa $\quad 79$

Fig. 72 Terminal da Lapa $\quad 79$

Fig. 73 Terminal da Lapa $\quad 80$

Fig. 74 Terminal da Lapa $\quad 80$

Fig. 75 Escola Estadual Jorn. Roberto Marinho 85

Fig. 76 Situação Escola Estadual Jorn. Roberto Marinho 86

Fig. 77 Situação Escola Estadual Jorn. Roberto Marinho 86

Fig. 78 Implantação Escola Estadual Jorn. Roberto Marinho 88

Fig. 79 Planta térreo Escola Estadual Jorn. Roberto Marinho 88

Fig. 80 Planta térreo Escola Estadual Jorn. Roberto Marinho 89

Fig. 81 Corte esquemático Escola Estadual Jorn. Roberto Marinho 90

Fig. 82 Planta pavimento superior Escola Estadual Jorn. Roberto Marinho 91

Fig. 83 Escola Estadual Jorn. Roberto Marinho 92

Fig. 84 Escola Estadual Jorn. Roberto Marinho 92

Fig. 85 Escola Estadual Jorn. Roberto Marinho 93 
Fig. 86 Escola Estadual Jorn. Roberto Marinho 93

Fig. 87 Escola Estadual Jorn. Roberto Marinho 94

Fig. 88 Escola Estadual Jorn. Roberto Marinho 94

Fig. 89 Residência em Ubatuba, São Paulo 95

Fig. 90 Situação Residência em Ubatuba, São Paulo 95

Fig. 91 Situação Residência em Ubatuba, São Paulo 96

Fig. 92 Implantação Residência em Ubatuba, São Paulo 97

Fig. 93 Planta térreo Residência em Ubatuba, São Paulo 98

Fig. 94 Planta térreo Residência em Ubatuba, São Paulo 99

Fig. 95 Residência em Ubatuba, São Paulo 100

Fig. 96 Residência em Ubatuba, São Paulo 101

Fig. 97 Residência em Ubatuba, São Paulo 101

Fig. 98 Centro de Saúde em Felanitx 105

Fig. 99 Situação Centro de Saúde 105

Fig. 100 Situação Centro de Saúde 106

Fig. 101 Implantação Centro de Saúde 107

Fig. 102 Centro de Saúde em Felanitx 108

Fig. 103 Planta térreo Centro de Saúde 109

Fig. 104 Planta pavimento superior Centro de Saúde 109

Fig. 105 Centro de Saúde em Felanitx 110

Fig. 106 Centro de Saúde em Felanitx 111

Fig. 107 Centro de Saúde em Felanitx 112

Fig. 108 Loja e Cafeteria em Campos do Jordão 113

Fig. 109 Capela de São Pedro Apóstolo em Campos do Jordão 114

Fig. 110 Implantação Loja e Cafeteria em Campos do Jordão 115

Fig. 111 Distribuição dos fluxos Loja e Cafeteria em Campos do Jordão 116

Fig. 112 Loja e Cafeteria em Campos do Jordão 116

Fig. 113 Loja e Cafeteria em Campos do Jordão 117

Fig. 114 Loja e Cafeteria em Campos do Jordão 118

Fig. 115 Loja e Cafeteria em Campos do Jordão 118

Fig. 116 Residência no Jardim América, São Paulo 123

Fig. 117 Situação Residência no Jardim América, São Paulo 123

Fig. 118 Situação Residência no Jardim América, São Paulo 124

Fig. 119 Residência no Jardim América, São Paulo 125

Fig. 120 Plantas Residência no Jardim América, São Paulo 126

Fig. 121 Residência no Jardim América, São Paulo 127

Fig. 122 Residência no Jardim América, São Paulo 128

Fig. 123 Residência no Jardim América, São Paulo 128

Fig. 124 Residência no Jardim América, São Paulo 129

Fig. 125 Residência no Jardim América, São Paulo 130

Fig. 126 Edifício Comercial, São Paulo 131

Fig. 127 Situação Edifício Comercial, São Paulo 132

Fig. 128 Situação Edifício Comercial, São Paulo 132

Fig. 129 Planta térreo Edifício Comercial, São Paulo 133 
Fig. 130 Corte esquemático Edifício Comercial, São Paulo

Fig. 131 Planta primeiro pavimento Edifício Comercial, São Paulo

Fig. 132 Planta segundo pavimento Edifício Comercial, São Paulo

Fig. 133 Planta terceiro pavimento Edifício Comercial, São Paulo

Fig. 134 Edifício Comercial, São Paulo

Fig. 135 Edifício Comercial, São Paulo

Fig. 136 Diagrama verão Edifício Comercial, São Paulo

Fig. 137 Diagrama inverno Edifício Comercial, São Paulo

Fig. 138 Edifício Comercial, São Paulo 


\section{INTRODUÇÃO}

A arquitetura dispõe elementos no espaço para captar, refletir, diluir e também emitir a luz.

Parte-se do princípio de que a luz do dia além de atender a uma demanda de funcionalidade, pode ser tratada como matéria prima de composição da arquitetura. Este trabalho pretende fazer uma reflexão sobre o aprendizado e a conscientização dos arquitetos formados pela FAUUSP entre os anos de 1985 e 2005 quanto à utilização da luz do dia em seus projetos. Neste recorte serão abordados cinco estudos de caso.

O processo de incorporação da luz do dia no processo criativo de jovens arquitetos egressos da FAUUSP que ocupam lugar de destaque no cenário da arquitetura contemporânea brasileira deve ser pesquisado e analisado pelo fato do curso de graduação em Arquitetura e Urbanismo da FAUUSP ser reconhecido como referência na história do ensino e da pesquisa em arquitetura e urbanismo no Brasil e ter tradição no ensino da disciplina de lluminação Natural.

Devido ao recorte cronológico estabelecido de vinte anos, este trabalho selecionou a cada quinquênio, um arquiteto que no seu exercício profissional tenha sua produção destacada através de concursos de projeto de arquitetura, de prêmios recebidos e da participação em grandes escritórios internacionais de arquitetura. A partir dessa divisão cronológica, foram selecionados para estudo os arquitetos Álvaro Puntoni, Luciano Margotto Soares, Vinícius Andrade, Marcelo Morettin, Caio Faggin, Fernando Forte, Lourenço Gimenes e Rodrigo Marcondes Ferraz. Cada profissional ou escritório de arquitetura que esses arquitetos integram como titulares tiveram duas obras analisadas relativamente à incorporação da luz do dia enquanto elemento de composição na arquitetura.

A metodologia de pesquisa adotada ocorreu em cinco etapas. Para o embasamento teórico do trabalho, inicialmente buscou-se fazer uma revisão bibliográfica pertinente ao tema. Na segunda etapa foram realizadas entrevistas com os arquitetos selecionados como estudos de caso, a partir de um roteiro básico de perguntas (Apêndice, p. 141). A visita e o levantamento fotográfico de algumas obras selecionadas de cada profissional foram realizados na terceira etapa do trabalho. A seleção das obras de cada arquiteto deu-se por indicação do próprio profissional e também pela abordagem, no edifício, da luz do dia 
enquanto elemento de composição da arquitetura. Na etapa posterior foram realizados levantamentos dos ambientes físicos e do sistema de iluminação quanto às dimensões, o layout, os acabamentos e a tipologia das aberturas. A última etapa da pesquisa buscou interpretar e analisar os dados obtidos. A localização, a equipe técnica, um breve histórico da obra, o estudo analítico do edifício quanto a sua implantação, sua composição espacial, os materiais e as cores utilizados, e os aspectos funcionais e subjetivos da iluminação natural foram os critérios selecionados para o estudo e análise das obras.

Sabendo-se que a luz é necessária para a manifestação da matéria e sua posterior visualização pelo homem, o capítulo I apresenta uma reflexão sobre a luz do dia na arquitetura. As possibilidades de percepção do espaço e do vazio, da visualização de um componente, de um conjunto de formas ou do todo, onde a arquitetura se apresenta e se revela, ocorrem em função da existência do fenômeno luz.

O capítulo II traz a visão da luz do dia no pensamento e prática projetual do arquiteto Álvaro Luis Puntoni, formado pela FAUUSP em 1987, a partir de entrevista realizada, visitas efetuadas às obras selecionadas e da análise do uso da luz do dia em suas obras. Dentre a sua produção foram escolhidos uma residência e um edifício institucional como objetos de análise. Para o arquiteto todo projeto arquitetônico é uma síntese dos conhecimentos técnicos e históricos. A análise de um aspecto único, isoladamente, não define um partido arquitetônico. O projeto representa um conjunto de decisões e algumas delas ocorrem de maneira natural e intuitiva durante o processo de projeto.

O capítulo III expõe a visão da luz do dia no pensamento e prática projetual do arquiteto Luciano Margotto Soares, formado pela FAUUSP em 1989, a partir da mesma metodologia adotada. Um terminal de ônibus urbano e um centro comercial e de serviços foram os edifícios escolhidos para análise neste trabalho. $O$ arquiteto expõe que o espaço não pode ser analisado ou compreendido como uma simples entidade física, separado do tempo histórico, dos aspectos sociais de comunidades locais e da sociedade como um todo.

O capitulo IV mostra a visão da luz do dia no pensamento e prática projetual do escritório de arquitetura Andrade Morettin, cujos integrantes são os arquitetos Marcelo Morettin e Vinícius Andrade, formados pela FAUUSP em 1991 e 1992, respectivamente. Seguindo o procedimento adotado para os outros estudos de caso, o trabalho tem como foco de análise uma escola estadual e uma residência. A valorização da multidisciplinaridade 
é uma postura defendida pelo escritório durante o processo de projeto. Vinicius Andrade afirma que ao se praticar uma arquitetura mais coletiva e mais técnica, ela se torna menos autoral.

O capítulo $V$ aborda e faz uma análise da visão da luz do dia no pensamento e prática projetual do arquiteto Caio Faggin, formado pela FAUUSP em 1999. Foram selecionados para análise um centro de saúde e um edifício. A oportunidade de trabalhar como arquiteto no exterior lhe proporcionou a experiência de vivenciar a arquitetura e os edifícios icônicos de maneira diferente e o induziu a reflexões acerca da necessidade de se estar em processo de constante busca e transformação.

O capitulo VI apresenta a visão da luz do dia no pensamento e prática projetual do escritório de arquitetura FGMF, integrado pelos arquitetos Lourenço Gimenes, Rodrigo Marcondes Ferraz e Fernando Forte, formados pela FAUUSP em 2001, 2002 e 2003, respectivamente. A análise do uso da luz do dia em suas obras foi referenciada em uma residência e um edifício comercial. Uma analogia traçada entre arquitetura e os idiomas, expõe que cada idioma tem a sua própria forma de construção do pensamento e que não existe uma única maneira de se chegar a uma determinada forma de comunicação. Dependendo da lógica construída por cada profissional ao longo da vida, acumulando um repertório de comunicação, têm-se formas diferentes de abordagem, resultando numa multiplicidade de compreensões.

Por fim se apresentam as considerações finais deste trabalho que buscou fazer uma reflexão sobre como esses profissionais vêem e trabalham a luz do dia enquanto elemento de composição em seus projetos e apresentar as soluções por eles propostas nas obras analisadas. 


\section{CAPÍTULO I}

O FENÔMENO DA LUZ

Do latim Luce: agente suscetível de estimular o órgão próprio dos seres que têm a faculdade da visão. A luz é uma modalidade de energia radiante que se propaga através de ondas eletromagnéticas, capaz de sensibilizar os olhos humanos.

\footnotetext{
"We live in a sea of light. Our entire world is known to us through waves of electromagnetic energy pulsing through the air, and we distinguish every speck and formation in that universe as patterns of bright against dark." (PLUMMER, 1987, p. 9)
}

No século 17, Sir Isaac Newton expôs a sua Teoria Corpuscular da Luz. Após diversas experiências com prismas, ele chegou à conclusão que a luz branca era composta por todas as cores que compõem o arco-íris. Nessa teoria, a luz era considerada como um feixe de partículas emitidas por uma fonte de luz que atingia o olho, estimulando a visão.

Em 1678, o físico holandês Christian Huygens defendeu um modelo ondulatório da luz. Segundo ele, a luz seria formada por ondas, cada cor correspondendo a um comprimento de onda próprio, com velocidade diferente dentro do prisma.

A existência das ondas eletromagnéticas foi comprovada, em 1887, através de experimentos realizados por Heinrich Hertz. Ao mesmo tempo em que gerou ondas de rádio, as ondas hertzianas, ele observou que a incidência de luz sobre um objeto metálico provocava uma corrente elétrica. Ao conseguir produzir ondas eletromagnéticas em laboratório, medir seu comprimento e velocidade, demonstrando que elas possuíam todas as propriedades da luz, a mesma natureza das vibrações e da suscetibilidade de reflexão e refração da luz e das ondas quentes; o físico alemão anunciou a descoberta do efeito fotoelétrico.

Albert Einstein, em 1905, publicou o artigo sobre efeito fotoelétrico. Segundo ele, sob certas condições, a luz se comporta como uma partícula. Esta teoria postulava que a energia dos raios luminosos se transfere em unidades individuais chamadas quanta, 
contrariando as teorias anteriores que afirmavam que a luz era manifestação de um processo contínuo. Essa teoria marcou a base da atual teoria sobre a natureza da luz.

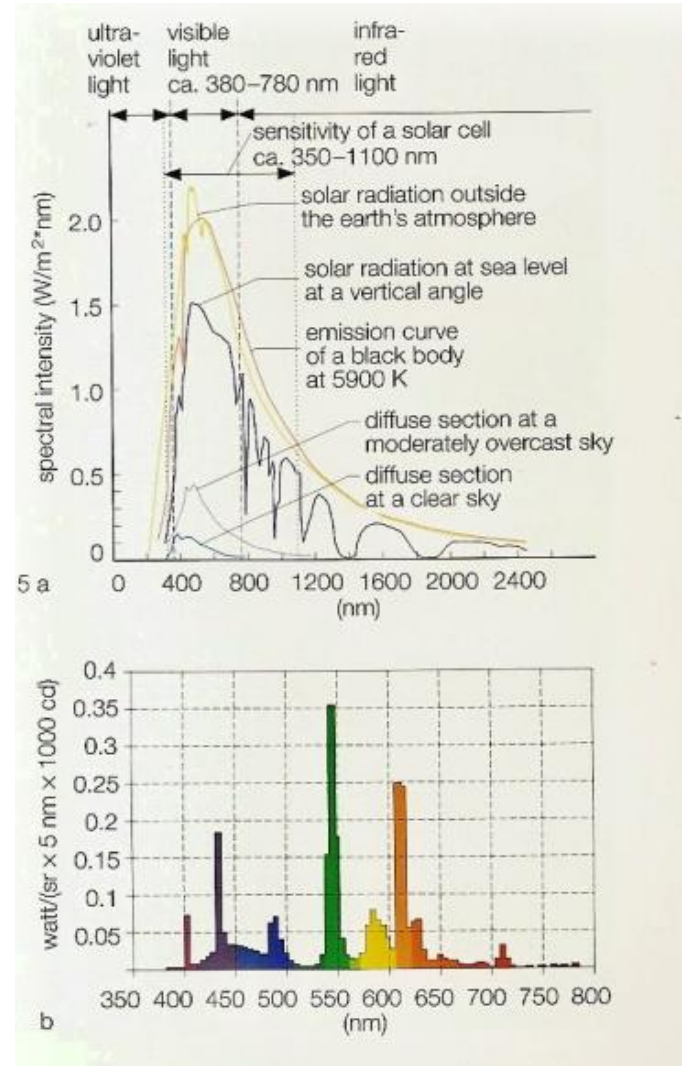

Fig.1 - Composição do espectro solar Fonte:Detail Practice. Lighting Design, 2006, p.9

Sendo a luz uma radiação eletromagnética dual que se comporta como onda e como matéria, com diferentes comprimentos de onda, desde os raios cósmicos com ínfimos comprimentos de onda até as ondas de rádio frequência muito baixa, com comprimento de milhões de quilômetros; sabe-se que é o único componente do espectro eletromagnético que pode ser detectado pelo olho humano. Os objetos são percebidos quando eles refletem a luz em direção aos nossos olhos.

A velocidade de propagação da luz é de $299.743 \mathrm{~km} / \mathrm{segundo}$. A passagem da luz é frequentemente descrita em termos de raios que se propagam em linha reta. Caso exista algum objeto na trajetória de alguns desses raios, a sua passagem será bloqueada, criando uma área de sombra.

Desde o nascimento, o homem esforça-se em obter a luz. Ela é a base da existência no planeta. Sem luz, o homem não respira, não vê e nem percebe as cores. Assim como é a 
fonte de energia para a fotossíntese, a luz é também a primeira fonte de vida para o ser humano.

É inegável a dependência da luz pelos seres vivos, sejam animais ou vegetais. A luminosidade e o ciclo diário dos organismos vivos estão diretamente conectados e a presença da luz influencia o estado de ânimo do homem.

\begin{abstract}
"Natural light brings to our planet the motive force behind these quiet perturbations, with its evolving yet oscillating current of energy, always transforming and coloring, yet always revolving the same way it has since the dawn of time. The light of the sky is always mutating, yet always returning to the same point in space and time. Daylight is ever new in its brightening and dimming, cooling and warming, sharpening and blurring, strengthening and weakening, rising and setting, yet it is also the most convincing evidence we have on the face of the earth that life is able to repeat and endure. Perhaps the secret of eternity lies in this flowing and metabolic kind of order - a mobile energy from the skies which always recurs but never quite the same, and so is always in a state of becoming." (PLUMMER, 1995, p. 350)
\end{abstract}

Segundo Moore (1985, p.24), a visão é a habilidade do olho em perceber a porção do espectro da radiação definida como luz. Os limites da sensibilidade do olho humano são muito próximos aos do espectro solar, pelo fato de a evolução humana ter ocorrido durante o dia e sob a luz do sol.

A visão permite ao homem o acesso ao mundo a distância, à velocidade da luz. Schmid (2005, p.276) afirma que para onde quer que olhemos durante o dia, quando os objetos refletem luz e se fazem visíveis, capturamos as propriedades geométricas essenciais. A cada fração de segundo, a visão de uma pessoa reconhece milhões de diferentes pontos com características de luz e cor.

A primeira fonte natural de luz é o sol, que define não apenas o espaço, mas também o tempo com as suas mudanças de cores e sombras.

"The sun's design effects were discovered during the birth of art and architecture, and for millennia daylight has defined the beautiful and the ugly, the exceptional and the ordinary, the sacred and the profane, and the serious and the frivolous. Whatever the impact of those effects, subtle or dramatic, light is a potent vehicle for human expression." (MICHEL, 1996, p. 2) 
A luz altera o estado orgânico e afetivo do homem, pois quando passa pelo olho, impulsos são propagados para áreas do cérebro relacionadas às emoções e à regulação hormonal. A sua influência sobre os neurotransmissores cerebrais modifica a atenção, o humor e o comportamento humano. A ausência da luz solar influi negativamente sobre o estado de ânimo do homem, afetando a capacidade do cérebro no manuseio da informação.

O ciclo circadiano da luz - noite e dia - produz o estímulo de neurotransmissores cerebrais. A luz diurna ativa e estimula essa produção, levando serotonina ao cérebro. $\quad \mathrm{Na}$ ausência do estímulo luminoso, ocorre uma produção maior de melatonina, acarretando sonolência ao homem.

Além disso, a luz é necessária para que a matéria se manifeste e se torne visível. A possibilidade da percepção do espaço e do vazio, da visualização de um componente, de um conjunto de formas ou do todo, onde a arquitetura se apresenta e se revela, dá-se em função da existência do fenômeno luz. A arquitetura dispõe elementos no espaço para captar, refletir, diluir e também emitir a luz.

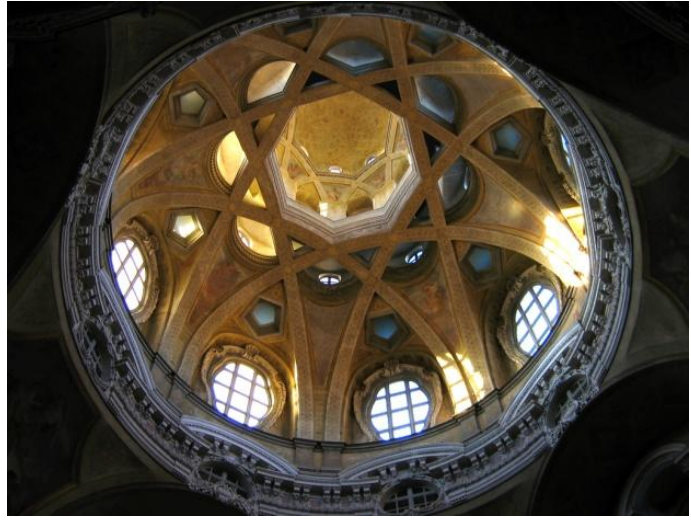

Fig.2 - Igreja de San Lorenzo - Turin Fonte: http://www.skyscrapercity.com

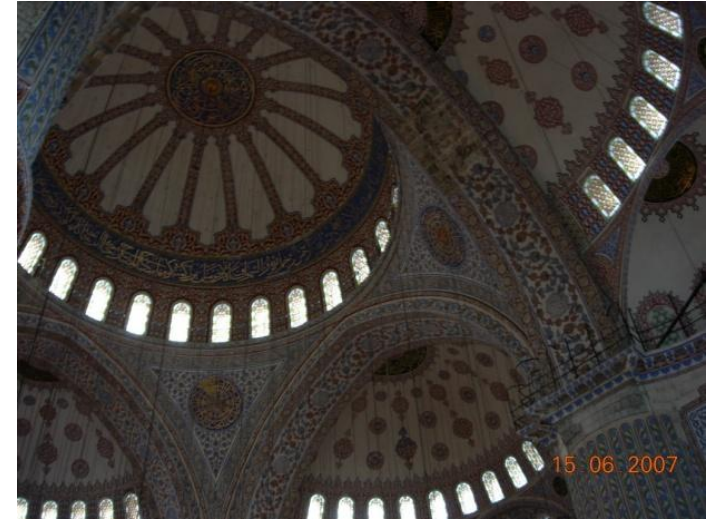

Fig.3 - Mesquita Azul - Istambul Fonte: acervo pessoal da autora

\subsection{A LUZ DO DIA E A ARQUITETURA}

A maneira como a luz do dia tem sido manipulada historicamente pelos arquitetos reflete características das diferentes culturas e, frequentemente narra uma história que difere da linguagem mais racional da forma e do espaço. A história da arquitetura, em todos os períodos, é rica em exemplos do valor dado à iluminação natural em diferentes tipologias de edifícios. A luz do dia como modeladora de formas, como elemento dinâmico que 
proporciona a integração do interior com o exterior, que traz a percepção da temporalidade ao espaço e que integra a arquitetura ao meio.

"I sense Light as the giver of all presences, and material as spent Light. What is made by Light casts a shadow, and the shadow belongs to Light. I sense a Threshold: Light to Silence, Silence to Light - an ambiance of inspiration, in which the desire to be, to express crosses with the possible." (KAHN, 1997, p. 16)
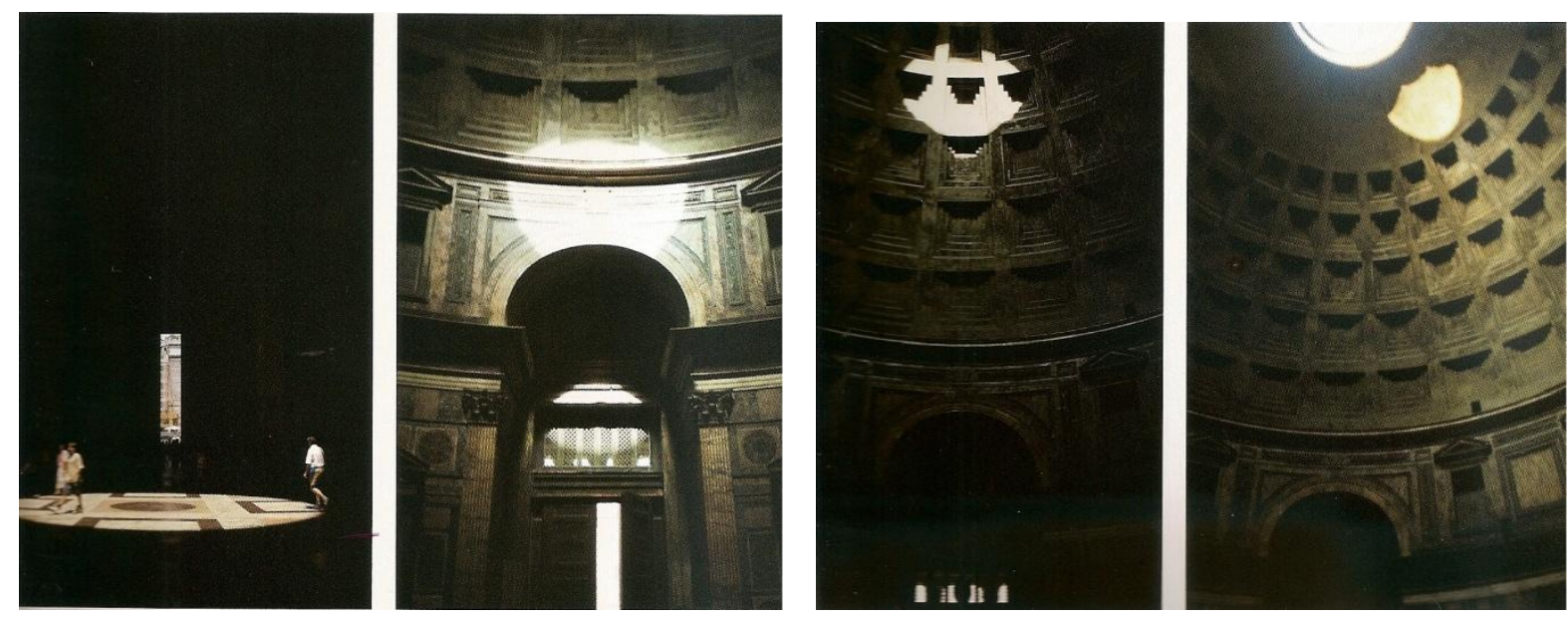

Fig.4 - Pantheon, Roma Fonte: Made of light, p.135

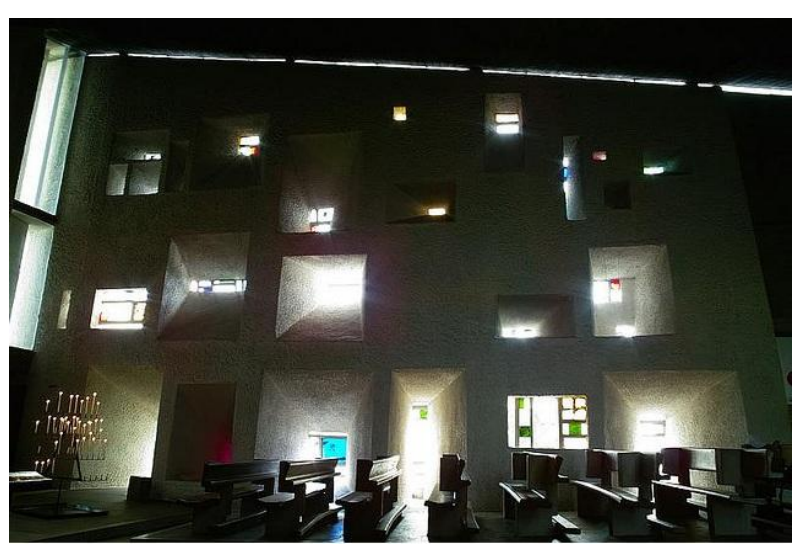

Fig.5 -Le Corbusier, Notre Dame du Haut, Ronchamp

Fonte: http://www.flickr.com/photos/mb17chung

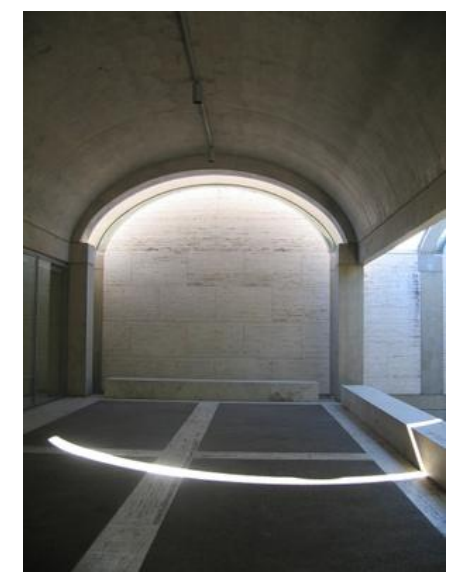

Fig.6 -Louis Kahn, Kimbell Art Museum, Texas

Fonte:http://dmitri1201.blogspot.com 

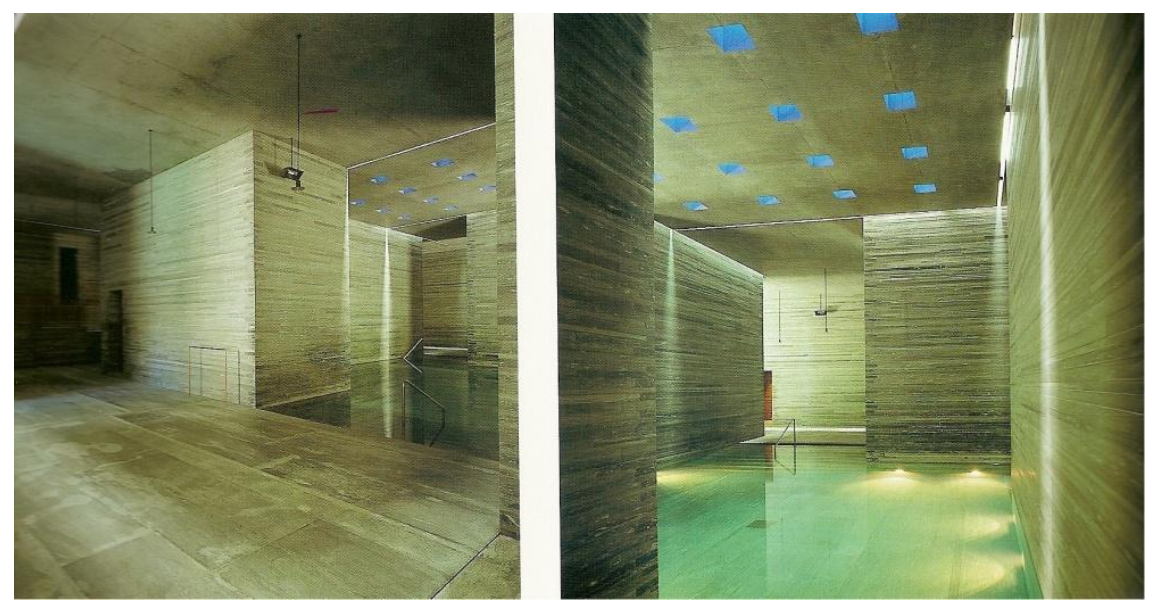

Fig.7 - Peter Zumthor, Termas de Vals, Suíça Fonte: La arquitectura de la luz natural, p.63

Le Corbusier (2004, p.135) afirma: "já perceberam que faço uso abundante da luz. Ela constitui, para mim, a base fundamental da arquitetura. Componho com a luz".

Reiter (2004, p.168) acredita que a luz é portadora de diferentes sentidos e significados para cada indivíduo e que, uma vez reconhecida a sua capacidade de imprimir uma ideia a um espaço, torna-se necessário diferenciar o potencial de significados que ela pode oferecer ao ambiente.

A arquitetura depende da luz. Como a luz revela as formas da arquitetura e os espaços concebidos por ela, simultaneamente revela o significado e as intenções que são liberadas através do processo de conceber, projetar e construir.

A luz é para a arquitetura o local onde se situa o tempo. A luz é responsável por situar a obra no dia ou na noite, e marcar a passagem das sombras, varrendo os ambientes ao longo do ano.

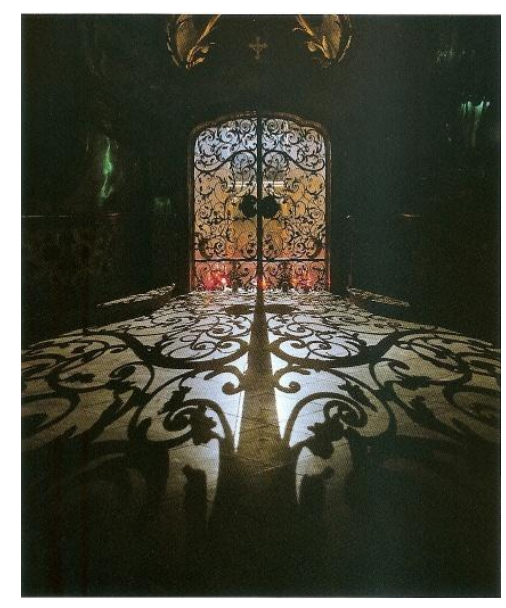

Fig.8 - Forma e caráter Fonte: Made of light, p.64 
Apesar de a luz ser apenas mais um dos elementos de composição da arquitetura, ela revela o edifício, suas intenções, suas formas, seus espaços e seus significados. A luz do dia revela a arquitetura e, nos melhores exemplos, a arquitetura revela a luz.

Major (2005) acredita que não importa o que estejamos fazendo em nossas vidas, a luz está presente. A luz é uma ferramenta de comunicação, é energia, é mágica. Luz é vida e nosso mundo é feito de luz.

Os edifícios e as cidades fornecem o horizonte para a compreensão e enfrentamento da condição existencial humana. Em vez de criar meros objetos de sedução visual, a arquitetura se relaciona, medeia e projeta significados. O sentido último de qualquer edifício é além da arquitetura, que dirige a nossa consciência de volta ao mundo e para o nosso próprio sentido de existir. A arquitetura significativa nos faz experimentar a nós mesmos como seres materiais e espirituais. Essa é a grande função de toda a arquitetura. (PALLASMAA, 2005)

"Light is really the source of all being".

(KHAN 1997, p.16)

\subsection{LUZ E LUGAR}

Os padrões da luz que nos acompanham desde o nosso nascimento têm significado para nós. Alguns desses significados são universais e são imagens arquetípicas com as quais a humanidade compartilha. Alguns desses significados são culturais, absorvidos através de rituais ou simplesmente refletindo uma atitude perante a vida. Outros significados são pessoais e estão associados a eventos particulares ou a pessoas. A nossa experiência acumulada da luz em lugares é complexa, multifacetada e rica.

Cada lugar, em particular, tem a sua luz. O lugar como forma de expressão da luz engloba dois aspectos distintos: o próprio lugar, com suas características físicas que o tornam único, e o conjunto de mudanças que ocorrem nele ao longo do tempo, gerando padrões distintos da luz do dia ao longo do dia ou através das estações do ano.

Millet (1996, p.8) explica que cada lugar é definido exclusivamente devido à quantidade ilimitada de combinações que nele revelam a luz. Para a autora, a luz modela tanto a perspectiva do prédio como também a luz que entra no edifício. Assim como o 
espírito do lugar, genius loci, pode ser transmitido por responder de forma sensível à sua luz. O caráter da luz, suas cores e ritmos são os grandes contribuintes para a definição do genius loci.

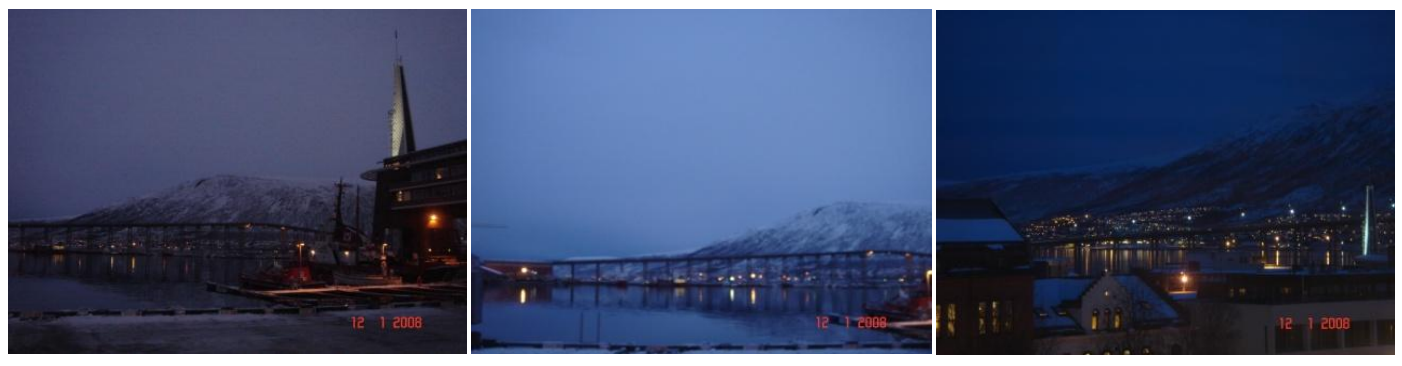

Fig. 9 - Tromso, Noruega, 8:00h, 12:00h e 16:00h - lat.6939' N - long.185ㅇ' L Fonte: acervo pessoal da autora

\subsection{LUZ E CLIMA}

A cor, o ângulo e a qualidade da luz dependem diretamente da latitude, do tipo de céu e do clima de um determinado lugar.

A influência das forças naturais - a trajetória aparente do sol, as condições do céu, o clima e a natureza do lugar - de uma determinada região sobre a luz do dia deste local, determina as estratégias a serem adotadas pelo projeto de arquitetura. O sol, o clima e o lugar moldam a arquitetura, assim como os materiais e técnicas construtivas utilizadas na construção dos edifícios.

As informações relativas às temperaturas anuais, níveis de precipitação, umidade relativa do ar, condições do céu, ventos dominantes, topografia, vegetação e estrutura do terreno podem ser usadas para determinar os padrões sazonais que influenciam na iluminação, no aquecimento e ventilação do edifício.

O desenho das aberturas de um edifício determina a integração ou separação entre o interior e o exterior, o contato visual ou físico com o lugar, o acesso ao sol, ao vento, aos sons e até mesmo aos odores. 

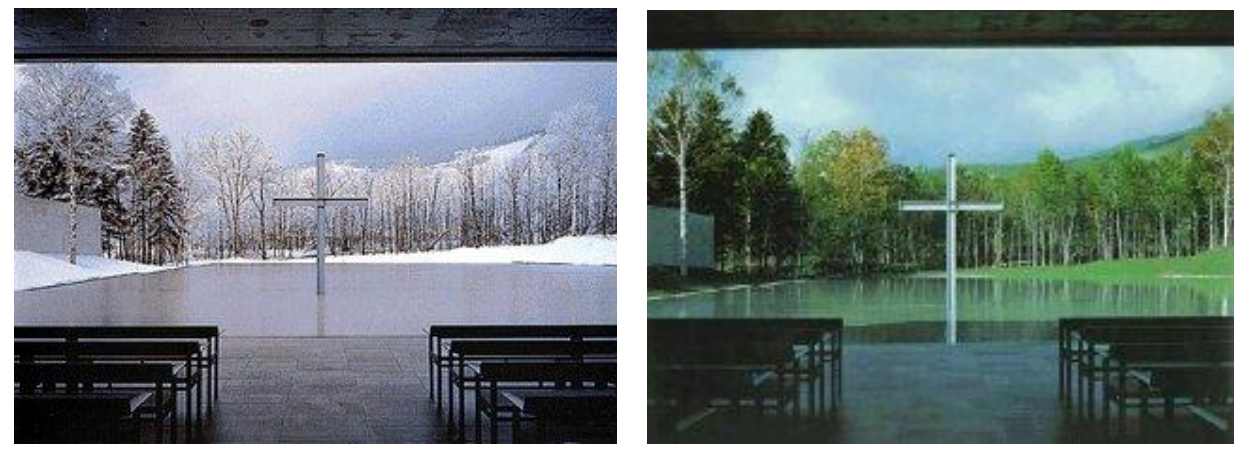

Fig. 10 - Church on the Water,Tomamu, Japan.Tadao Ando Fonte: http://victorian.fortunecity.com/parkstreet/418/tadao/water.html

\title{
1.4. LUZ E TEMPO
}

A marcação do tempo é o mais óbvio fenômeno resultante do movimento do sol. O aspecto pragmático do tempo - as horas, minutos e segundos - mantém a vida do homem estruturada e organizada e, esse tempo mecânico, atrelado ao relógio, independe de seu ritmo biológico.

A luz do dia é uma das principais formas de conexão entre o ritmo biológico do homem e o ritmo da natureza.

\subsection{SIMBOLOGIA DA LUZ}

\begin{abstract}
“Em numerosos casos, as fronteiras ficam indecisas entre a luz-símbolo e a luzmetáfora. Por exemplo, pode-se perguntar se a luz, aspecto final da matéria que se desloca com uma velocidade limitada, e a luz de que falam os místicos têm alguma coisa em comum, a não ser o fato de serem um limite ideal e um resultado. Vai-se na direção do símbolo, por outro lado, quando se considera a luz como um primeiro aspecto do mundo informe. Embrenhando-se na sua direção, entra-se num caminho que parece poder levar além da luz, isto é, além de toda forma, mas, igualmente, além de toda sensação e de todo conceito". (CHEVALIER, GHEERBRANT, 1991, p. 567 apud VIREL, 1965, p.259 e 265)
\end{abstract}

Iluminar, refletir, desvendar, ocultar, revelar, esclarecer e inspirar são atributos inerentes da luz.

A simbologia da luz é universal e fundamental: reflete o espiritual e o divino, a iluminação e a inteligência, a bondade e a verdade. 
“Em sua alusão ao divino, ao imaterial, ao bem e à vida, a luz é um dos símbolos religiosos primordiais da humanidade. Em todas as suas manifestações - sol, lua, relâmpago, fogo - a luz corresponde à natureza da divindade". (LURKER, 2003, p. 403)

O lighting designer e professor universitário Howard M. Brandston enfatiza que a luz permite ao homem ver não apenas através de seus sentidos, mas também através de sua alma, evocando diferentes sentimentos em cada pessoa. Para um filósofo, a luz é uma metáfora do conhecimento; para um cientista, ela é o componente fundamental de seu trabalho; e para um cenógrafo, ela é uma ferramenta de manipulação das emoções.

\footnotetext{
"Light signifies the triumph of culture over ignorance, good over evil. "As far as we can discern, "Karl Jung wrote, "the sole purpose of human existence is to kindle a light in the darkness of being." (BRANDSTON, 2008, p.20)
}

A luz, segundo o autor, é quem dá ritmo à vida, regula os dias, as noites, as estações do ano e o relógio biológico do homem.

Ao longo da história, os aspectos sagrados da luz e do tempo têm sido representados nos espaços construídos, como afirma Guzowski (1999, p.6), citando como exemplos os monolitos de Stonehenge, os templos de Chichén Itzá e Machu Picchu.

\footnotetext{
"The experience of time through light is a physical and emotional sensation rather than a phenomenon that can be quantified and measured. Light tells a different story about time than does a clock or a calendar. Light is an experience of time that is about place, nature, and even the sacred." (GUZOWSKI, 1999, p.6)
}

A luz está relacionada com a obscuridade para simbolizar os valores complementares ou alternantes de uma evolução. Essa lei se verifica nas imagens de numerosas civilizações. Sua significação, assim como acontece na vida humana em todos os seus níveis, é a de que uma época sombria é seguida, em todos os planos cósmicos, de uma época luminosa, pura, regenerada.

“A Lua valoriza religiosamente o devir cósmico e reconcilia o homem com a Morte. O Sol, ao contrário, revela um outro modo de existência: não participa do devir; 
embora em constante movimento, o Sol permanece imutável, sua forma é sempre a mesma. As hierofanias solares traduzem os valores religiosos da autonomia e da força, da soberania, da inteligência". (ELIADE, 1992, p.128)

Szabo (1995, p.188) escreveu: "a utilização da palavra luz em termos simbólicos é bastante conhecida; um dos melhores exemplos é a famosa frase de Nehru quando da morte de Gandhi: "a luz de nossas vidas se apagou; só nos restam as trevas". Porém existe linguagem simbólica da luz arquitetônica, que, mesmo silenciosa, fala com clareza".

Em seu livro, Reiter afirma que a luz é portadora de diferentes sentidos e significados para cada indivíduo e que, uma vez reconhecida a sua capacidade de imprimir uma ideia a um espaço, torna-se necessário diferenciar o potencial de significados que ela pode oferecer ao ambiente.

\footnotetext{
"La lumière et l'obscurité sont souvent mises em relation pour marquer une dualité. Toutefois, l'obscurité fait partie de notre expérience de la lumière: tout comme le noir s'avère nécessaire pour compléter le blanc, l'omble se montre indispensable pour cerner la lumière." (REITER, p. 168)
}

Segundo esses significados, o autor classifica a luz do dia em seis categorias: luz geral para iluminação, luz cenográfica, luz emoção, luz contemplativa, luz metafórica e luz simbólica.

A definição de luz geral para iluminação, segundo o autor, é aquela que, ao incidir em um espaço, permite que ele seja observado no todo e, conforme o tipo de uso, as atividades possam ser ali desenvolvidas adequadamente. O conforto visual é o fator determinante dessa categoria de iluminação.

Como luz cenográfica, entende ser aquela que estabelece o ambiente arquitetônico, atraindo a atenção do observador para alguns componentes do espaço e deixando outros elementos sob a sombra. A luz representa, ao mesmo tempo, um dos materiais componentes da arquitetura e também um vetor de percepção do espaço.

A luz emoção tem como objetivo atrair a atenção do usuário do espaço, a fim de suscitar emoções e sentimentos. Como exemplo, ele cita a Capela de Notre-Dame du Haut em Ronchamp, de Le Corbusier, onde o espetáculo de luz e cores toca profundamente o visitante. 
A luz contemplativa, geralmente sutil e tranquilizante, favorece a concentração, a introspecção e a contemplação.

A luz metafórica pode sugerir uma associação de ideias com um lugar desconhecido ou com uma imagem natural. Reiter observa ainda que a interpretação das metáforas depende exclusivamente da visão pessoal de cada um ao observar o espaço. Como exemplo, ele cita o teto do hall de entrada da Casa Güell, de Antonio Gaudi, que sugere claramente um céu estrelado através da passagem da luz do dia pelas aberturas em sua cúpula.

A luz é portadora de fortes símbolos que contribuem para prover alma a um projeto, associando um significado que transcende ao mundo visível. A luz simbólica traduz sempre um conceito, uma ideia, seja ela relacionada à vida, à morte ou ao infinito. Na sacristia do Convento de La Tourette, de Le Corbusier, citada como exemplo, a forma oblíqua do espaço é revelada por sete aberturas, concebidas para permitir a entrada da luz do dia ao meio-dia, diretamente na nave da igreja, nos equinócios da primavera e do outono. Essa concepção ocorre também nas pirâmides e em alguns edifícios sagrados e faz a ligação entre a igreja e o cosmos. A luz simboliza a união entre os homens e o universo.

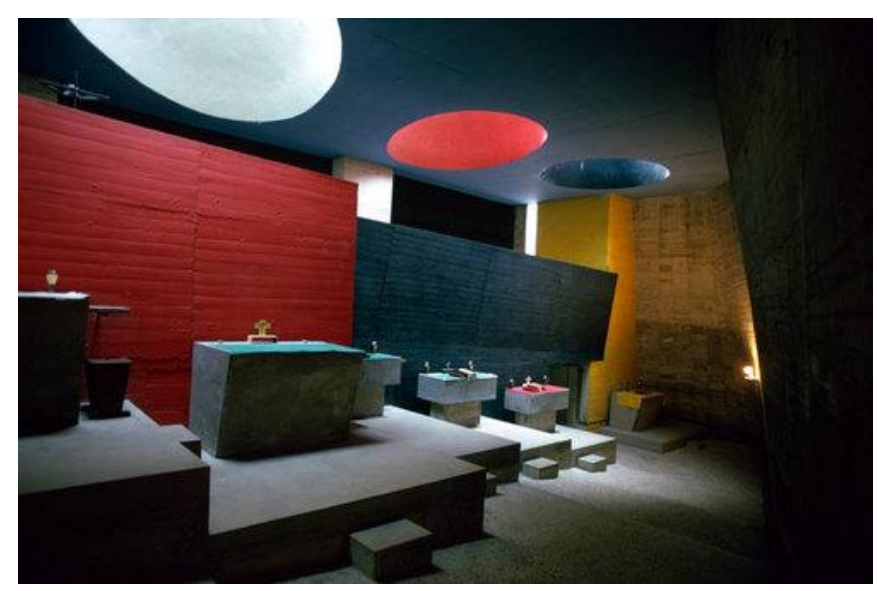

Fig.11 - Le Corbusier, Convento de La Tourette Fonte:http://www.farq.edu.uy/estructura/talleres/parodi/croquis.htm

O papel fundamental do arquiteto é, por um lado, modelar formas e, por outro, catalisar as diversas oportunidades de percepção do espaço. As formas, as massas, os materiais, os volumes, os espaços e as superfícies são aspectos permanentes e estáveis de um edifício que podem ser tocados, mensurados e observados. Com relação à luz, seus aspectos estão relacionados à reflexão, à sombra, à tonalidade, à atmosfera, aspectos 
fluidos e etéreos de um edifício, que podem ser capturados e sentidos através da percepção e sensibilidade.

A luz implica o fato de que a arquitetura pode extrapolar o seu nível físico e abranger uma realidade metafísica. 


\title{
CAPÍTULO II
}

\section{A VISÃO DA LUZ DO DIA PARA O ARQUITETO ÁLVARO PUNTONI}

\author{
"E entendemos que, para realizar uma obra correta, seria preciso caminhar \\ dentro de um regime de austeridade, usar corretamente os materiais e obter a \\ precisão na construção. Costumamos dizer que nossa arquitetura pressupõe poucas \\ ações construtivas, mas que têm de ser muito precisas". (PUNTONI, 2009, p.61)
}

Álvaro Luis Puntoni, arquiteto formado pela Faculdade de Arquitetura e Urbanismo da Universidade de São Paulo - FAUUSP, em 1987, com Mestrado em 1999 e Doutorado em 2005 por esta mesma instituição. É professor de Projeto na Universidade Anhembi Morumbi desde 1997, na FAUUSP, desde 2002 e também na Escola da Cidade, desde o mesmo ano, da qual é sócio fundador e Coordenador do Conselho Pedagógico. Trabalhou com os arquitetos Angelo Bucci e Alvaro Razuk de 1987 a 1992. Com Angelo Bucci, trabalhou também entre 1992 e 1996; e de 2002 a 2004 no SPBR Arquitetos. Atualmente participa do Gruposp.

A sua formação acadêmica ocorreu entre os anos de 1982 e 1987, período que coincide com o final da ditadura militar e o início da abertura política no país, com o movimento das Diretas Já. Esse período marca também o auge da discussão do movimento Pós-Moderno na arquitetura e das críticas à Arquitetura Moderna no Brasil. Para Álvaro Puntoni, esse debate, apesar de ainda não solucionado, foi salutar, pois permitiu mais liberdade na forma de se olhar a arquitetura.

$\mathrm{O}$ arquiteto acredita que a FAUUSP tenha exercido um papel importante em sua formação, visto que a instituição representava a ideia de escola, de formação e de inteligência construída.

“No Brasil, mais notadamente em São Paulo, as novas gerações de arquitetos formadas em parte pelos professores, seus alunos, os alunos dos alunos - não abdicaram da inteligência construída no período anterior". (PUNTONI, 2008, p.81)

A noção da técnica, oriunda dessa formação, serviu para que ele tivesse uma visão estrutural do desenho e um olhar sobre o território como um espaço novo a ser transformado. A sua dedicação como aluno à disciplina de Projeto, somada à contribuição dos comprometidos professores de Projeto, possibilitaram a visão do arquiteto quanto ao processo de ensino: 
“Uma certeza cada vez maior que se educar como arquiteto é educar o olhar e capacitar você de continuamente aprender, sempre estar apto a aprender as coisas. Você não vai ser um bom arquiteto porque na escola você fez bons projetos ou porque teve um curso montado para abarcar todas as situações que o arquiteto enfrentará na vida. Você será um bom arquiteto porque você desenvolve uma aptidão diante dos desafios lançados na vida profissional. Você, a partir de uma metodologia desenvolvida ao longo dos seis, sete anos, é capaz de responder a essa demanda a partir dos seus conhecimentos técnicos e teóricos". (PUNTONI, Apêndice digital)

É impossível negar que a matriz da formação do arquiteto seja a Arquitetura Moderna brasileira, em especial a escola paulista e seus representantes. Seus trabalhos refletem o vínculo com a ideia de continuidade e, ao mesmo tempo, revelam uma identidade própria.

"A influência, no início, vinha mais da escola paulista? Sim, no início vinha mais da obra do Artigas, mas depois fomos conhecendo também outras manifestações, como Reidy, Lelé e o Oscar Niemeyer, que perpassa tudo isso". (aU, junho 2009, p.61)

“... 'Se pensássemos da mesma forma, criaríamos uma competição interna. Mas as qualidades de um complementam as do outro. E compartilhamos um ponto: o respeito à herança da escola paulista e a busca por fazer uma cidade melhor', avalia Jonathan". (DAVIES, 2010, p.49) ${ }^{6}$

A utilização de formas e repertórios semelhantes é o ponto de contato entre a Arquitetura Moderna e o trabalho desenvolvido por Álvaro Puntoni. Percebe-se que o repertório de soluções plásticas e construtivas adotado pelo arquiteto em seus projetos é preservado da Arquitetura Moderna, seja através da definição dos planos construtivos, da exploração de balanços, das estruturas independentes realçadas ou através das grandes aberturas.

"Quanto à questão do paradigma, se entendemos o moderno como uma atitude face à realidade, acho que ainda tem muita coisa que interessa. Estamos no século 21, mas somos ainda arquitetos do século 20. Não sei como serão os arquitetos do século 21, mas certamente todo o legado ético do moderno, entendido no seu

\footnotetext{
${ }^{6}$ Jonathan Davies, graduado em Belas Artes, ex-integrante do Gruposp.
} 
sentido mais amplo, permanece ou, pelo menos, deveria permanecer". (PUNTONI, 2009, p.63)

O aprendizado da iluminação natural em sua formação acadêmica aconteceu de acordo com as ofertas das disciplinas e dentro dos padrões da estrutura curricular do curso: Iluminação Natural, Iluminação Artificial e Conforto Térmico. O pensar na iluminação natural acontecia de forma intuitiva nas aulas de Projeto, pois não havia a clareza necessária por parte do arquiteto quanto à aplicação, na prática, dos conhecimentos teóricos adquiridos na disciplina de Iluminação Natural. Poucos professores de Projeto faziam referência à utilização da luz do dia no edifício e cobravam dos alunos as possíveis soluções arquitetônicas, diferentemente do que ocorria com relação ao lançamento de um partido estrutural, definição de materiais, revestimentos, etc.

Durante a sua formação, os modelos físicos não eram utilizados para a observação do comportamento da luz do dia no edifício. Hoje, em seu cotidiano profissional, os modelos físicos são executados para o estudo volumétrico e, permitem também a visualização do comportamento da luz no edifício, nas diferentes horas do dia. Além desse recurso, também são utilizadas como ferramentas auxiliares, as modelagens em 3D para a observação da iluminação natural.

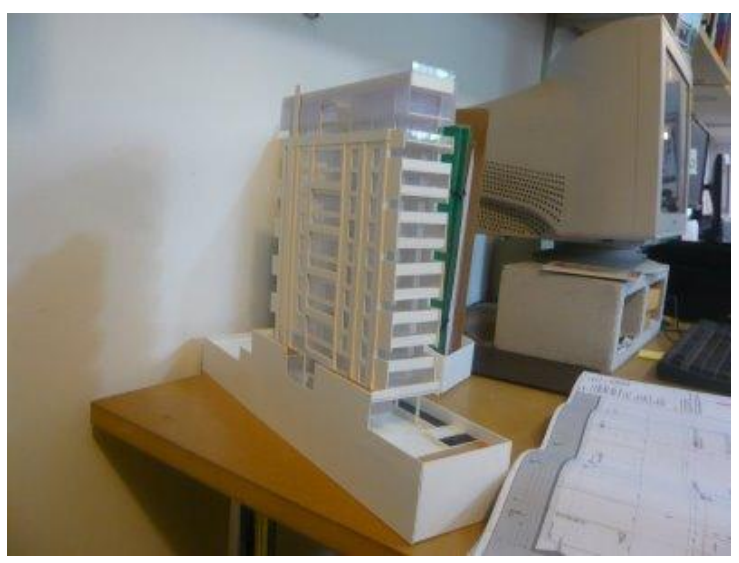

Fig.12 - Modelo físico no escritório do arquiteto. Fonte: http://newarchitects.blogspot.com/2009/03/grupo-sp.html

Todo projeto arquitetônico é, para ele, uma síntese dos conhecimentos técnicos e históricos. A análise de um aspecto único, isoladamente, não define um partido arquitetônico. O projeto representa um conjunto de decisões tomadas: definições quanto à 
implantação, à volumetria, quanto aos fluxos e percursos, quanto a um sistema estrutural, quanto às instalações, quanto à utilização de um determinado material ou revestimento.

\footnotetext{
“É impossível dissociar a arquitetura do lugar se a consideramos como uma instalação perene que se relaciona diretamente com o meio físico, social e cultural. Temos que defender serena e continuamente a idéia de fortalecimento de uma cultura nacional em que a arquitetura tem um papel significativo". (aU, jan.2009, p.13) ${ }^{7}$
}

Puntoni acredita que certas definições do partido arquitetônico ocorrem de maneira natural e intuitiva durante o processo de projeto. Apesar de ter consciência da importância e real significado da luz do dia no edifício - a luz como elemento que conforma espaços - o arquiteto não tem, em seu currículo profissional, nenhum projeto significativo onde a luz do dia tenha sido a protagonista do partido arquitetônico, ou mesmo trabalhada como um elemento de composição que tenha colaborado para a definição do partido. Em seu processo projetual, a definição da utilização da luz do dia ocorre de maneira intuitiva e diluída entre os demais elementos componentes do partido. O pensar na luz do dia e o cuidado com a sua utilização estão incorporados em seu processo de projeto,

Para Puntoni, o trabalho do arquiteto polonês, naturalizado mexicano, Abraham Zabludovsky, apresenta-se como um referencial em se trabalhar com a luz enquanto elemento de composição do espaço. Segundo ele, Zabludovsky projetava a iluminação natural ou a própria iluminação natural era a arquitetura para ele, e a sua arquitetura era feita de luz.

“Na obra de Zabludovsky, a concepção formal se deriva da solução estrutural, como suporte da proposta criativa. Uma preocupação permanente em suas obras foi a definição dos materiais, cujas características deveriam garantir sua permanência e propiciar a durabilidade do edifício, com a menor manutenção possível. Conceito que permitiu uma presença de grande dignidade em todas as suas propostas". (GRINBERG, 2003)

\footnotetext{
${ }^{7}$ Depoimento de Álvaro Puntoni para a Revista AU no texto O regionalismo está com os dias contados?
} 


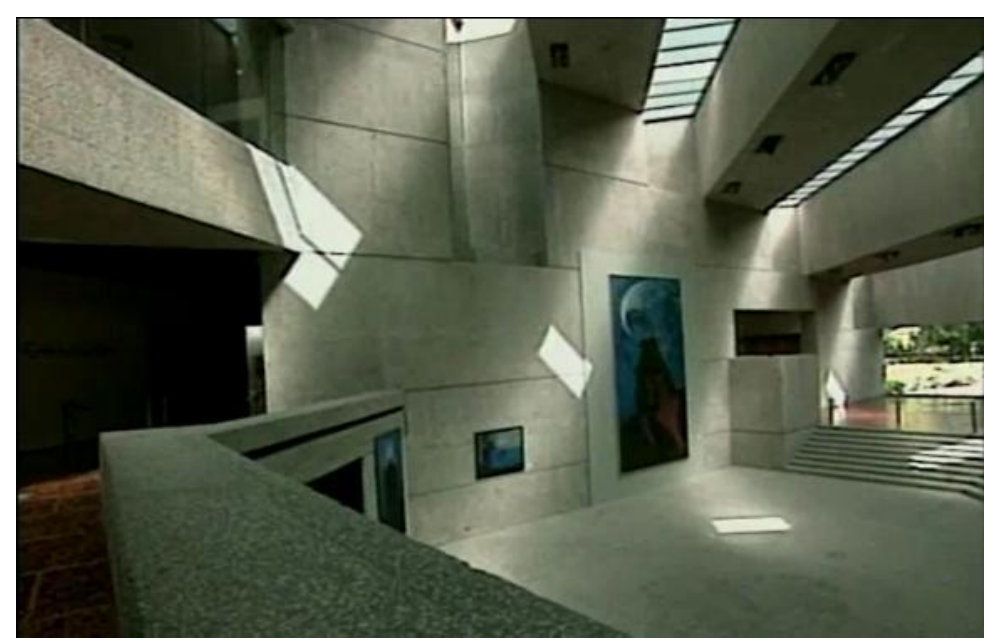

Fig.13 - Museu Rufino Tamayo, arquiteto Abraham Zabludovsky Fonte: http://www.urbanismo.com/abraham-zabludovsky-dominar-el-espacio-part-46/

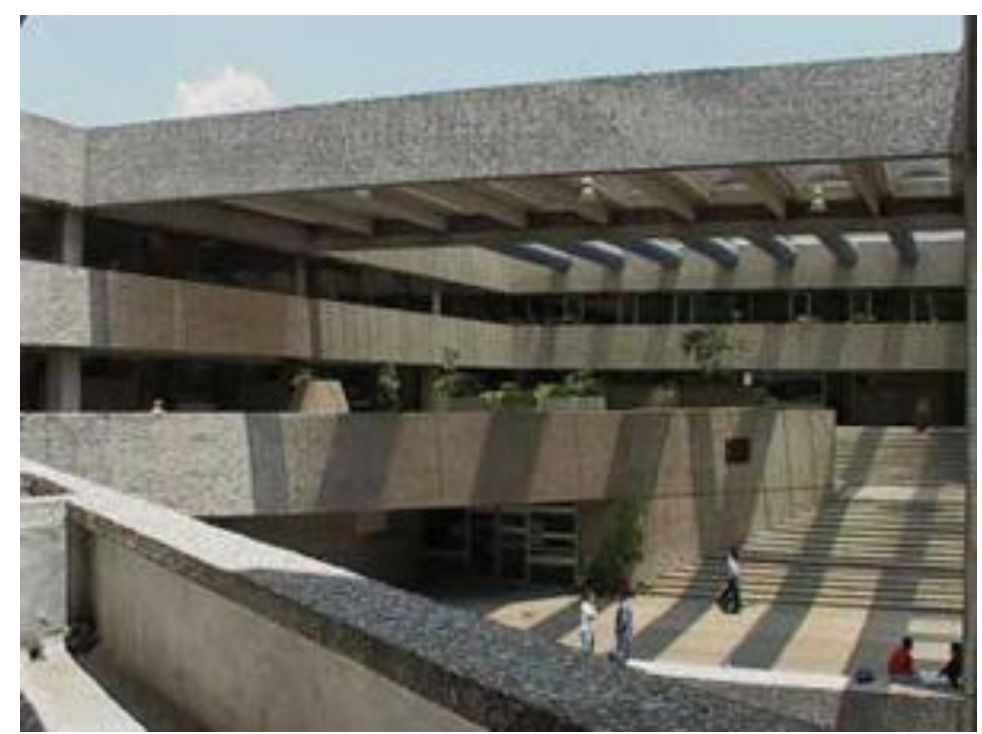

Fig.14- El Colegio de México, arquiteto Abraham Zabludovsky Fonte: http://bib.cervantesvitual.com/portal/ecm/pcuartonivel.jsp?nomportal=ecm\&conten=presentaction

Outros grandes arquitetos como Alvar Aalto, Álvaro Siza e Peter Zumthor também são citados como exemplos de profissionais que trabalham a luz do dia com gestos pontuais em seus edifícios. 
2.1. EDIFÍCIO I:

RESIDÊNCIA - COORDENADAS $23^{\circ} 34^{\prime} 23^{\prime \prime}$, $46^{\circ} 42^{\prime} 57^{\prime \prime} O$

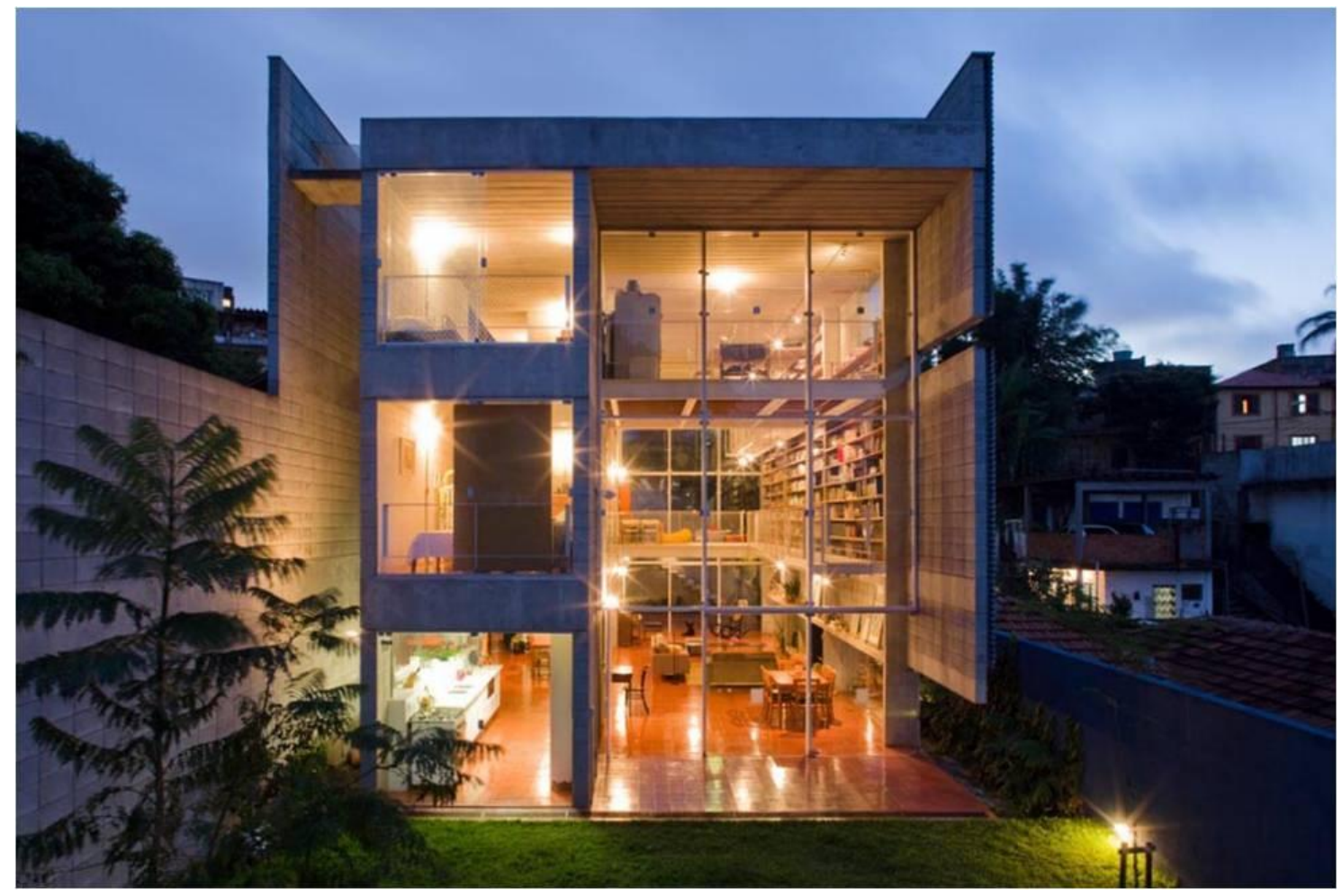

Fig.15- Residência no Morro do Querosene Fonte: acervo pessoal do arquiteto

\subsubsection{Localização}

A residência no Morro do Querosene está localizada na zona oeste da cidade de São Paulo, em uma região do bairro do Butantã, em um terreno com área de 450,00m2. 0 projeto arquitetônico foi realizado em 2005, e a obra no ano de 2006. 


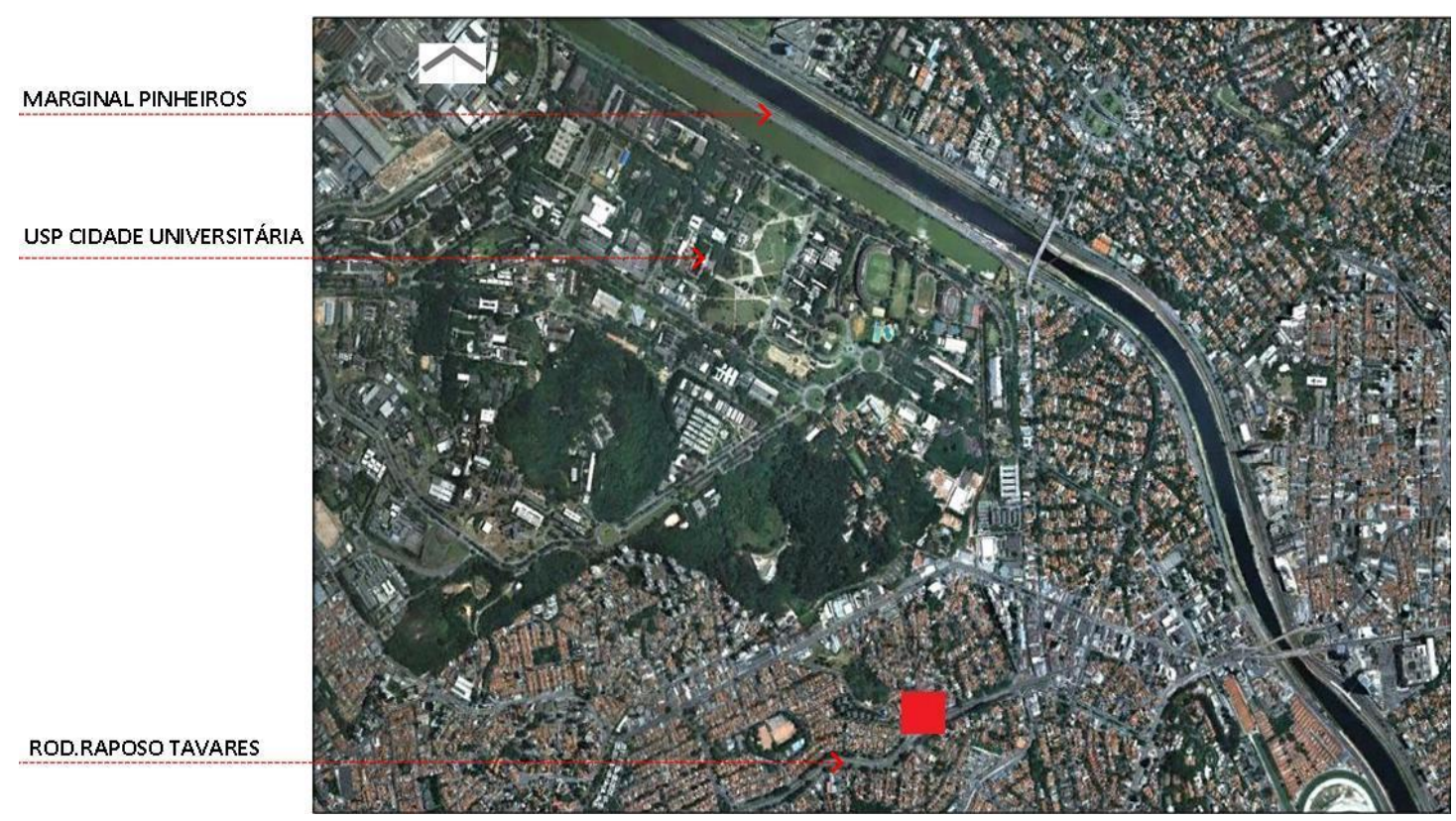

Fig.16- Situação Residência no Morro do Querosene Fonte: Google Earth

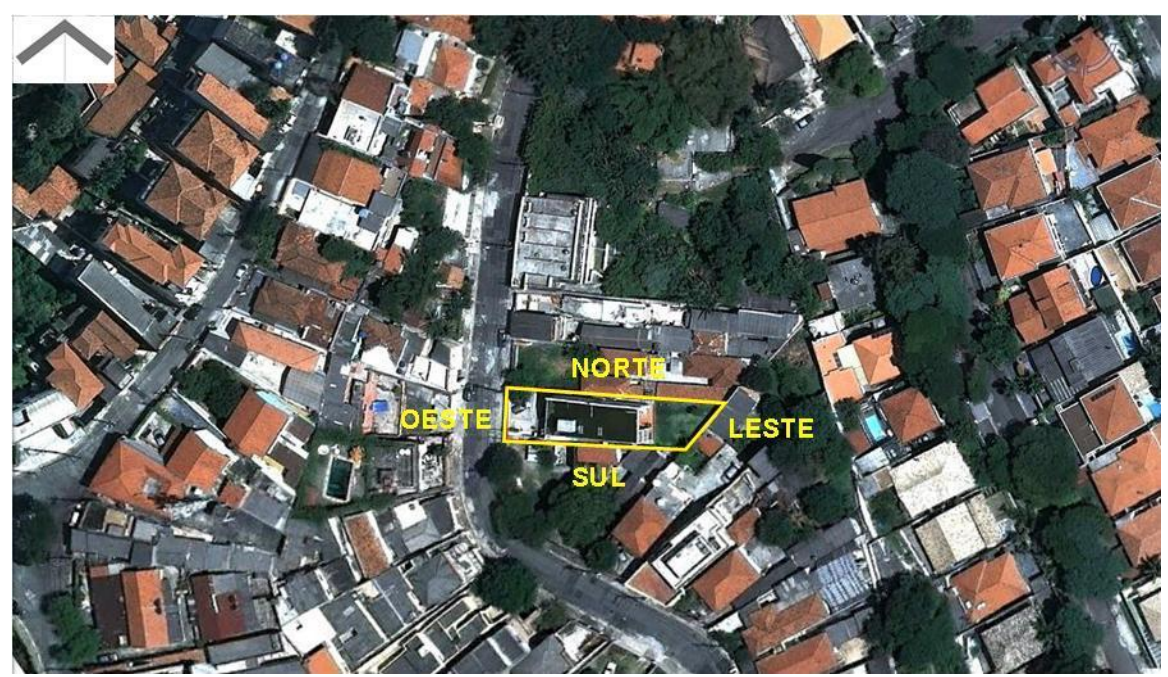

Fig.17 - Situação Residência no Morro do Querosene Fonte: Google Earth

\subsubsection{Equipe Técnica}

Projeto de Arquitetura: Álvaro Puntoni

Colaboradores: João Sodré e Jonathan Davies

Estrutura: Eduardo Duprat

Instalações Hidráulicas e Elétricas: Ramoska+Castellani

Construção: Robert Growald

Modelo físico: João Sodré

Modelo eletrônico: Jonathan Davies 


\subsubsection{Breve histórico}

Os proprietários, que antes moravam em um apartamento, ao optarem pela construção da residência, tinham questionamentos quanto à segurança ou insegurança em se morar em uma casa.

O projeto deveria atender à maior necessidade dos clientes que era a de abrigar 7.500 livros que compunham o acervo do casal de professores.

Partindo dessas premissas, o arquiteto pensou a edificação como uma caixa transparente, que revelasse o seu conteúdo ao meio e, dessa forma, não despertasse a atenção para indesejáveis intrusos.

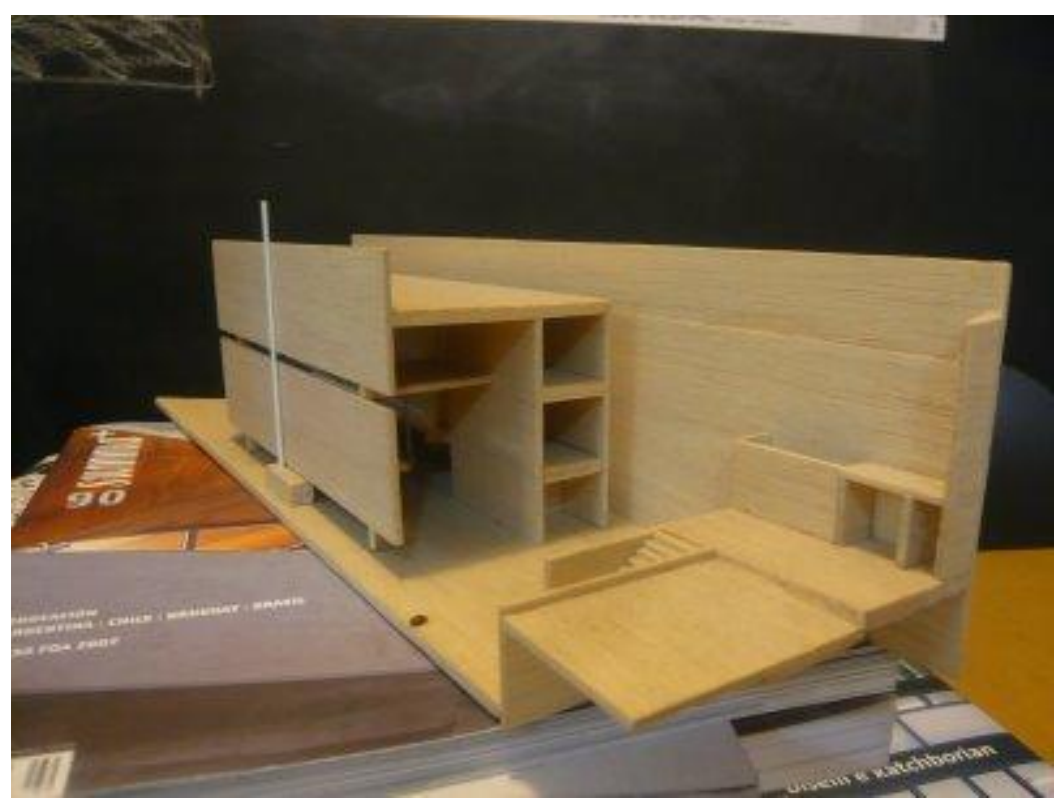

Fig.18 - Modelo físico residência no Morro do Querosene Fonte: http://newarchitects.blogspot.com/2009/03/grupo-sp.html

2.1.5. Estudo analítico do edifício: a implantação

Devido à pouca testada do lote e à sua topografia, que apresentava um declive acentuado para o fundo do terreno, a edificação foi implantada a 3,00 metros abaixo do nível da rua e encostada em uma de suas divisas laterais.

A solução formal adotada pelo arquiteto estabeleceu uma relação direta e transparente do espaço interno com a rua, sem comprometer o modo de vida e privacidade dos proprietários. 
O acesso à edificação ocorre através de uma escada localizada no nível da rua, junto à área destinada ao estacionamento de automóveis.

A edificação está orientada no sentido leste/oeste permitindo, desta forma, que todos os seus cômodos recebam a incidência direta da luz solar e favorecendo a ventilação natural cruzada.

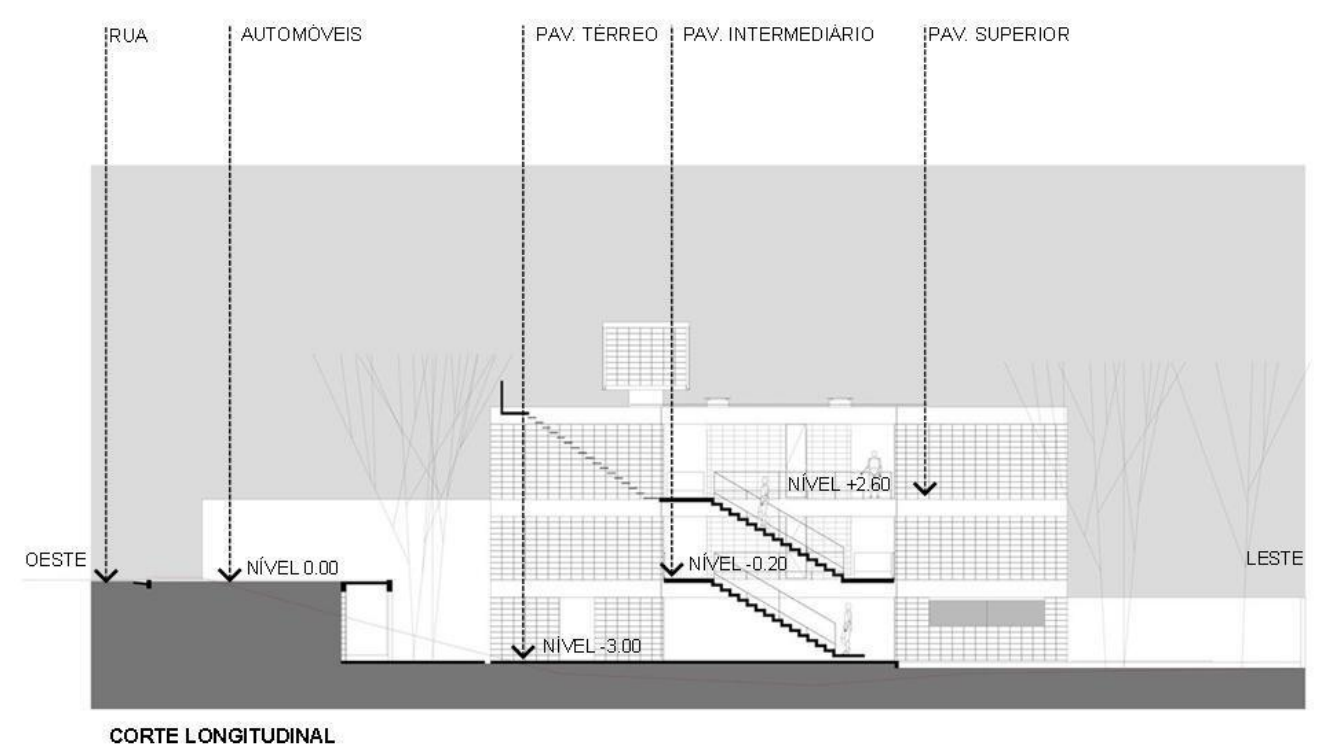

Fig.19 - Corte Longitudinal Fonte: acervo pessoal do arquiteto

\subsubsection{Composição espacial}

Três grandes planos paralelos e longitudinais ao terreno conformam o paralelogramo. O espaço contido entre os dois primeiros planos abriga os quartos, cozinha e área de serviço. $\mathrm{O}$ espaço contido entre o segundo e o terceiro plano comporta a sala/biblioteca. Toda a circulação vertical está contida em um quarto plano, paralelo aos anteriores, porém mais curto. Plataformas metálicas cruzam o espaço da biblioteca e o conectam com a área dos quartos, possibilitando a existência de uma sala no pavimento intermediário e um escritório no pavimento superior.

$\mathrm{O}$ arquiteto propôs que a área intima e a de serviços ficassem concentradas de um lado da edificação e, no outro lado, um grande vazio com pé direito triplo, que abrigasse os livros e a área social. Duas plataformas metálicas estabelecem a conexão entre as áreas 
intimas e de serviço com o grande vazio. Passarelas metálicas interligam, em cada nível, as plataformas com a grande estante.

Espaços de transição entre o interior e o exterior da edificação foram criados a partir de um recuo nas fachadas leste e oeste do espaço da biblioteca, desalinhando-as do plano do pavilhão.

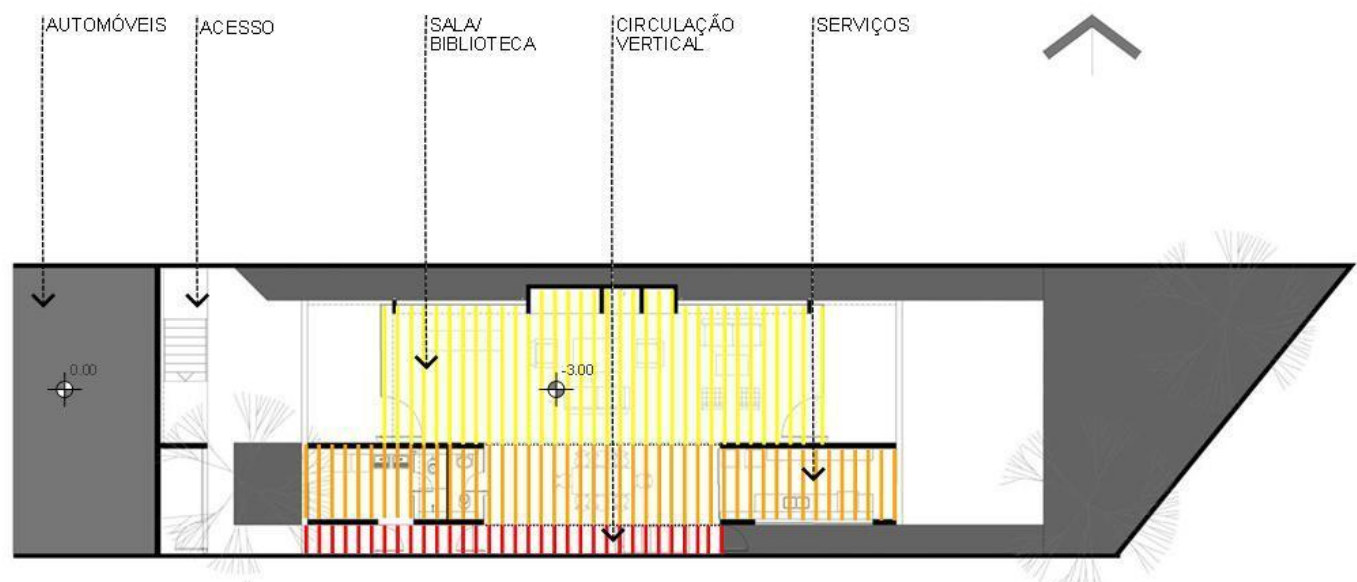

PLANTA PAVIMENTO TÉRREO

Fig. 20 - Planta pavimento térreo Fonte: acervo pessoal do arquiteto

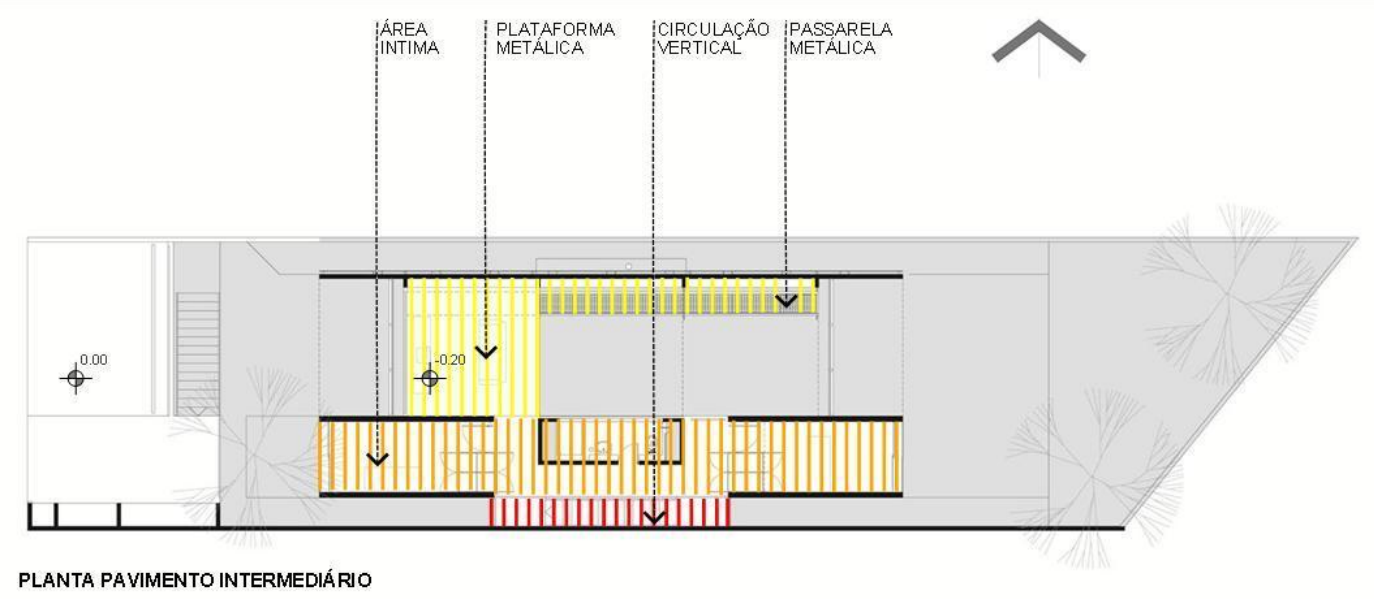

Fig.21- Planta pavimento intermediário Fonte: acervo pessoal do arquiteto 


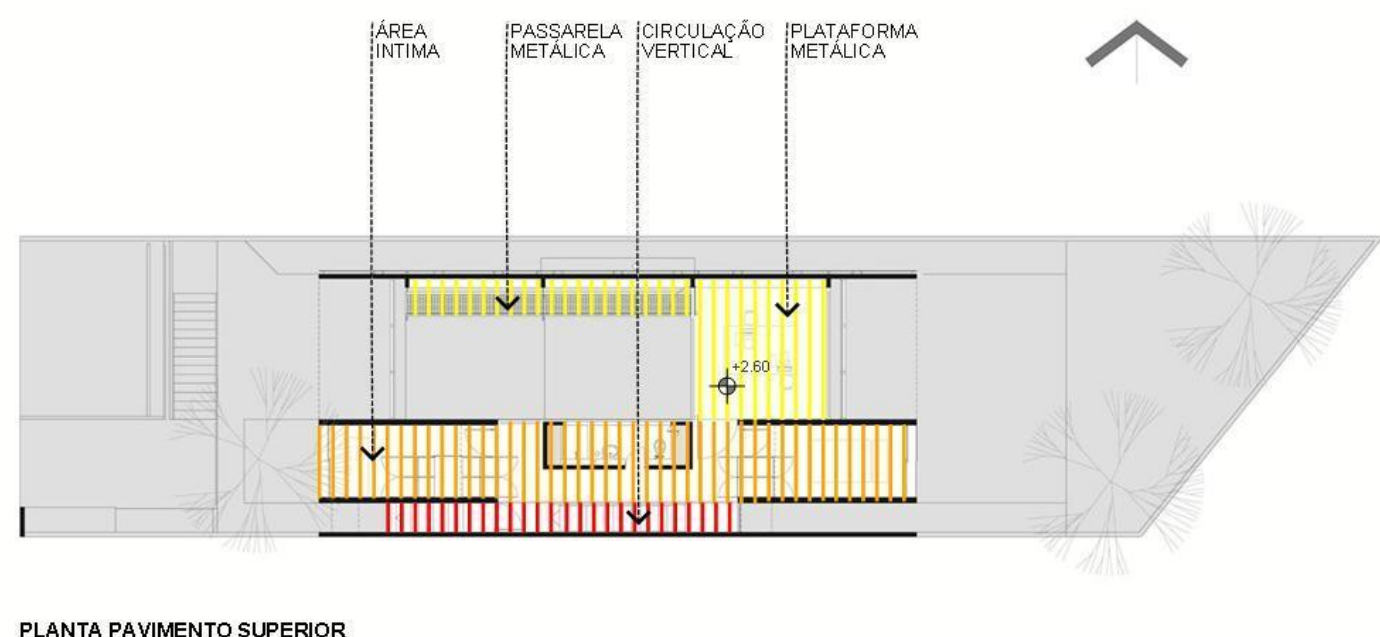

Fig. 22 - Planta pavimento superior Fonte: acervo pessoal do arquiteto

\subsubsection{Materiais e cores}

A estrutura do pavilhão é em concreto aparente com o fechamento em blocos de concreto. Toda a estrutura das passarelas é metálica e o piso foi executado em chapas de MDF assentadas sobre barroteamento de madeira.

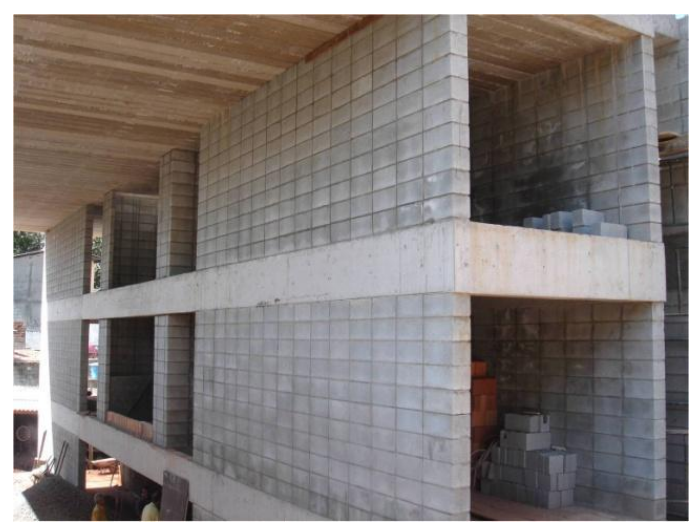

A fachada norte, onde internamente estão as estantes com os livros, foi revestida externamente com uma chapa metálica ondulada a fim de garantir sua proteção contra a chuva. Tal gesto permitiu a formação de um colchão de ar entre as duas superfícies, garantindo um maior isolamento térmico da fachada. 
A cobertura em laje pré-fabricada possui um espelho d'água que cobre boa parte de sua superfície. A presença da água na laje de cobertura contribui para o conforto térmico no interior da edificação.

Toda a instalação elétrica é aparente e executada através de conduletes metálicos em alumínio. $\mathrm{O}$ arquiteto propôs um totem elétrico composto por um ponto de iluminação, um interruptor e uma tomada. Esse totem se repete em toda a edificação, conforme a necessidade de cada ambiente.

Tanto a estrutura de concreto aparente quanto os blocos de concreto permaneceram com suas cores originais; a estrutura metálica das plataformas e passarelas recebeu tinta branca e o piso que reveste toda a edificação é ladrilho hidráulico na cor terracota.

\subsubsection{Iluminação natural: aspectos funcionais e subjetivos}

A orientação do edifício no sentido leste/oeste permite que todos os espaços recebam a incidência da luz solar.

No volume da sala/biblioteca, as fachadas leste e oeste têm seus fechamentos feitos com pele de vidro translúcido. Na fachada norte, no piso térreo, um painel horizontal fixo de vidro translúcido foi proposto, a partir do piso até a altura de meio pé direito. Nos quartos e serviços todo o fechamento é feito com vidro temperado translúcido. Na face norte, entre o pavimento intermediário e o superior, quase ao nível do piso entre as estantes, foi executado um rasgo horizontal ao longo de toda a parede. Nesta mesma fachada, junto à plataforma do escritório, no pavimento superior foi executada uma abertura, também com fechamento em vidro translúcido, de formato retangular, junto à laje de cobertura. Essa abertura não consta do projeto arquitetônico original, mas foi executada durante a obra quando se buscou privilegiar a vista. 

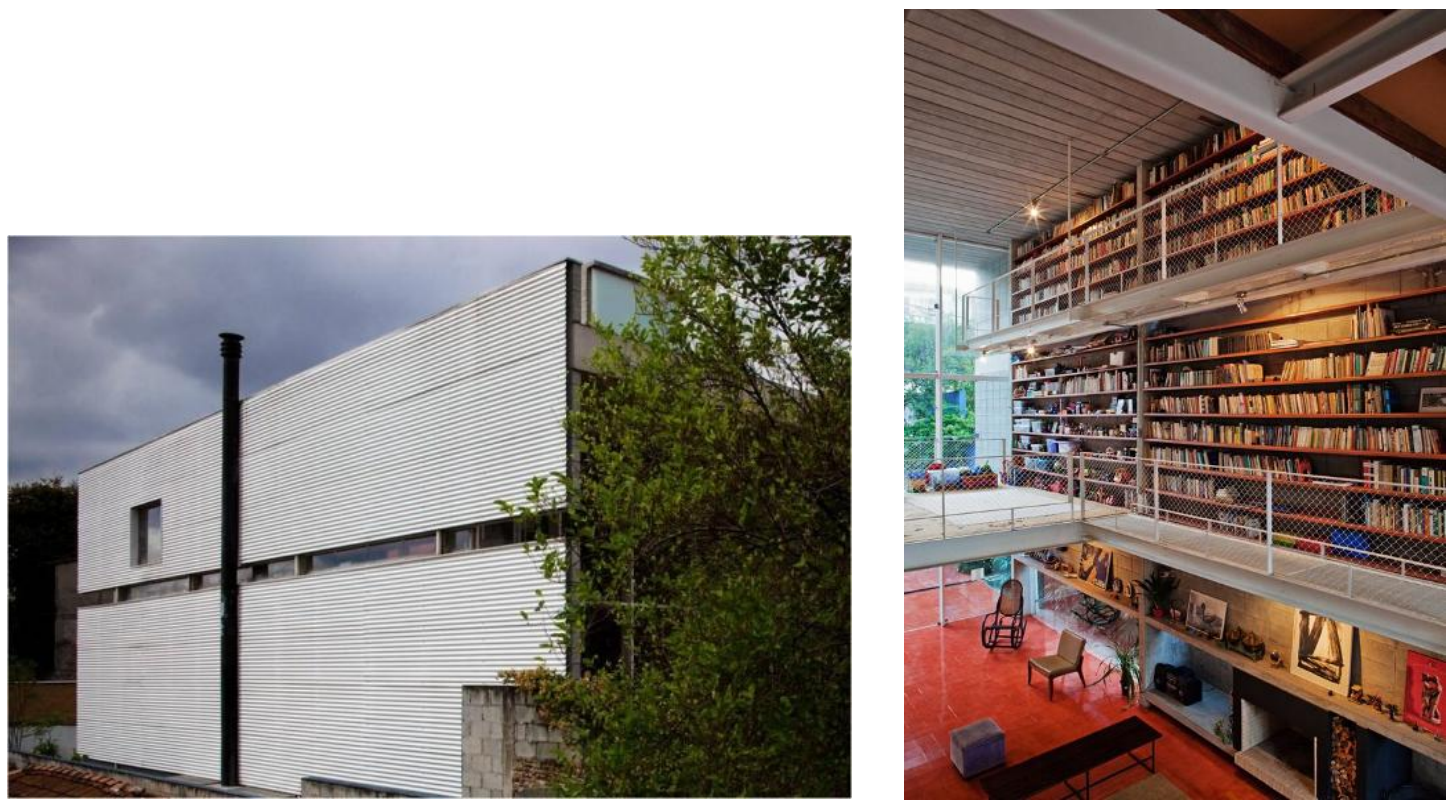

Fig. 24 - Residência no Morro do Querosene Fonte: acervo pessoal do arquiteto

Os banheiros não recebem iluminação natural direta, apenas através de seus painéis de fechamento, executados em vidro serigrafado branco. Os painéis que estão voltados para o espaço da biblioteca deixam passar a luz durante o dia e, à noite, permitem que o espaço interno da sala seja iluminado quando acesos os banheiros.

Duas aberturas na laje da cobertura, fechadas com vidro e ligadas aos banheiros, permitem a iluminação natural no banheiro do piso superior e contribuem para a ventilação dos banheiros nos dois pisos.

A escada está protegida contra a chuva através de uma cobertura de vidro que, além de garantir a estanqueidade, também permite a entrada da luz do dia.

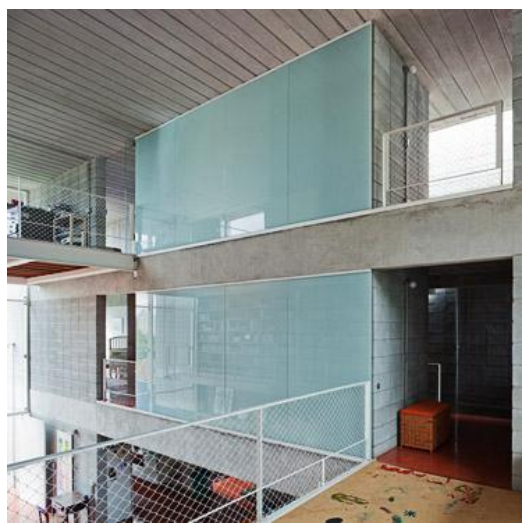

Fig.25 - Residência no Morro do Querosene Fonte: http://www2.nelsonkon.com.br

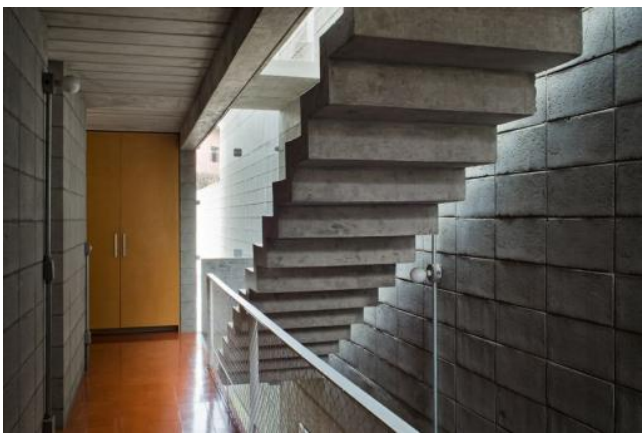

Fig.26 - Residência no Morro do Querosene Fonte: http://www2.nelsonkon.com.br 


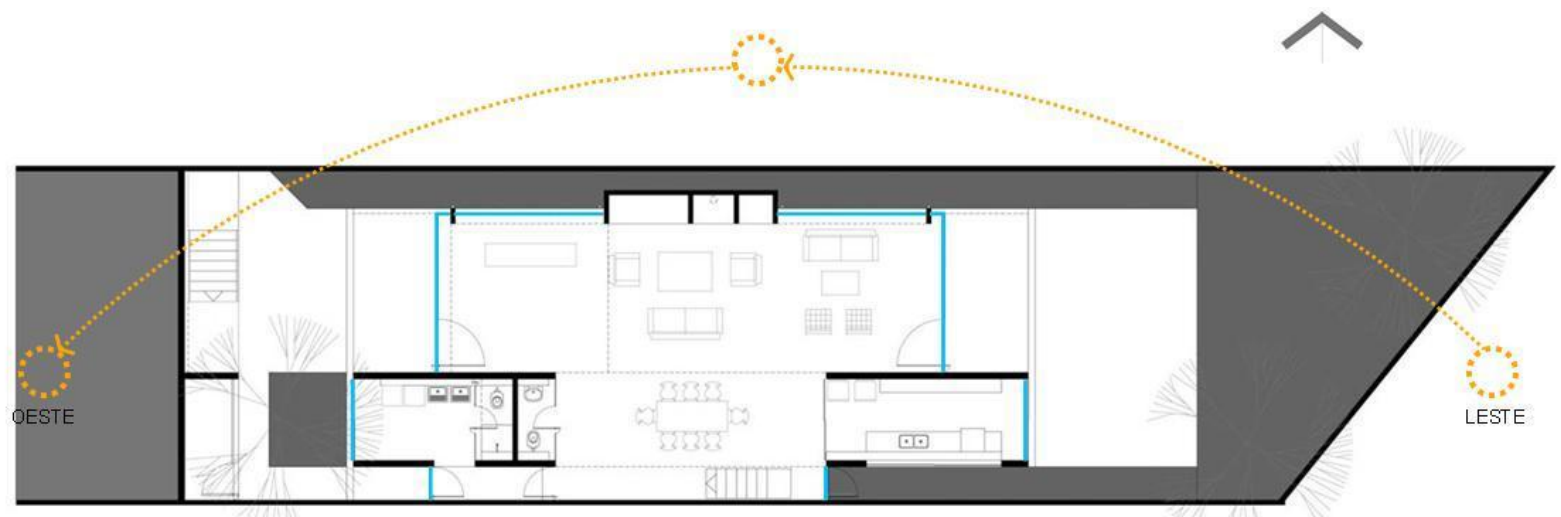

PLANTA PAVIMENTO TERREO

Fig.27 - Planta pavimento térreo - aberturas Fonte: acervo pessoal do arquiteto

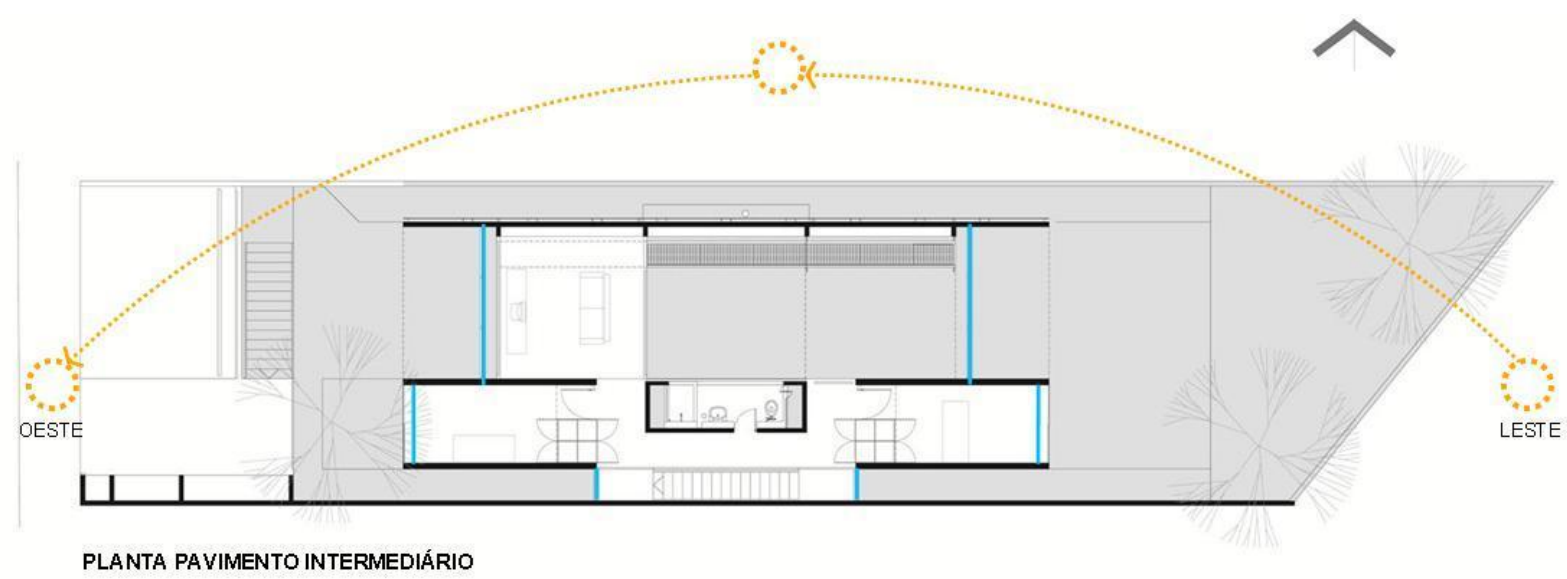

Fig. 28 - Planta pavimento intermediário - aberturas Fonte: acervo pessoal do arquiteto

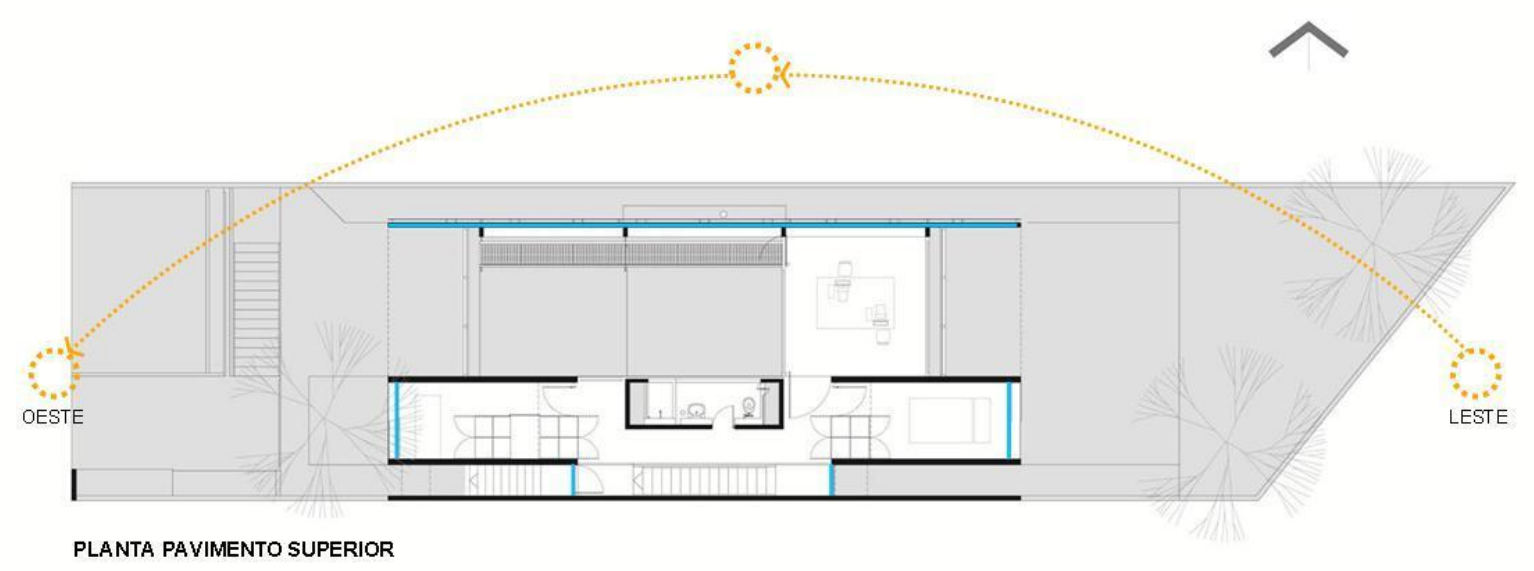

Fig.29 - Planta pavimento superior - aberturas Fonte: acervo pessoal do arquiteto 
A luz é permeada pelo sentido de visão do homem; a relação entre ver e ser visto é estabelecida através da arquitetura.

A edificação, de grande impacto visual, totalmente permeável à luz do dia, revela ao mundo a essência da vida de seus proprietários: o viver entre livros. Ao mesmo tempo em que se mostra como uma obra aberta através de suas membranas etéreas, ela incorpora o entorno, aproximando-se da cidade que a envolve.

A relação entre lógica estrutural e espacialidade deu origem à justaposição de dois gestos estruturais que foram tratados como duas entidades autônomas.

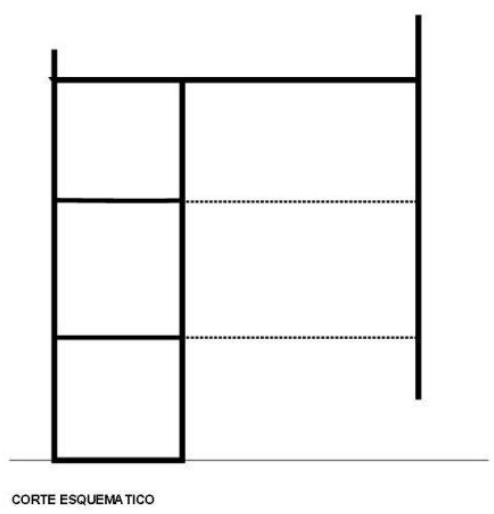

Fig. 30 - Corte esquemático Fonte: a autora

A casa, que parece flutuar sobre o solo, devido à interrupção da empena lateral norte e à utilização do vidro, com o rasgo de luz, junto ao piso, no volume da sala/biblioteca, evoca a sensação de imaterialidade.

O piso polido do pavimento térreo tornou-se uma grande superfície reflexiva da luz que atravessa todo o vazio envolvido pela grande cobertura. Assim como o piso, os painéis em vidro serigrafado, de fechamento dos banheiros, também se comportam como um espelho, refletindo não apenas a luz que percorre o espaço como também a causa principal de sua existência: os livros.

A opção pela transparência da passarela metálica vazada permite que a luz que entre pelo rasgo horizontal ao nível do piso, junto à estante de livros, a atravesse e chegue ao nível inferior, de maneira uniforme. 
A escada, descolada da parede e iluminada pela luz que entra em várias direções, torna-se o grande elemento escultórico da edificação, gerando sombra e contrastes de claro e escuro ao espaço da circulação.

Os gestos projetuais precisos do arquiteto, ora negando, ora admitindo a matéria, permitem ao observador a nítida percepção de contrastes gerados pela abundante luz do dia que permeia o espaço: a massa das paredes e a leveza dos fechamentos translúcidos; a cor e textura do piso polido e a diafaneidade dos fechamentos; a opacidade dos blocos de concreto e os painéis reflexivos dos banheiros; as cores das lombadas dos livros e a cor natural dos blocos de concreto.

A luz é uma metáfora para o conhecimento. Nessa obra não existem obstáculos. 0 grande vazio, atravessado pela luz do dia, é a principal matéria dessa residência.

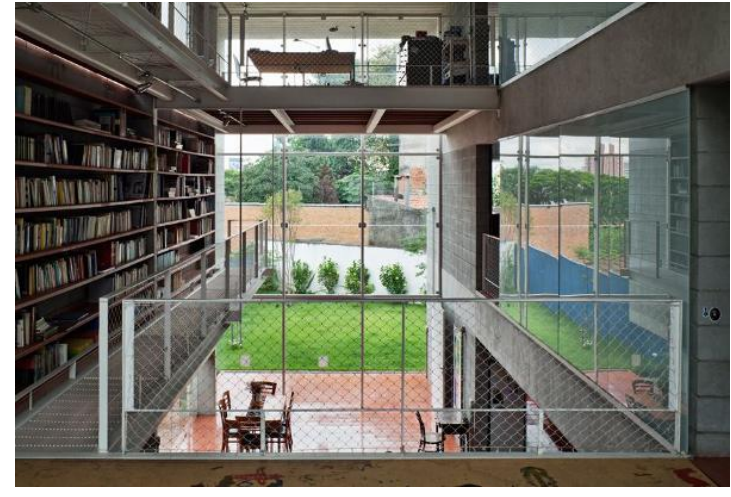

Fig. 31 - Residência no Morro do Querosene Fonte: http://www2.nelsonkon.com.br

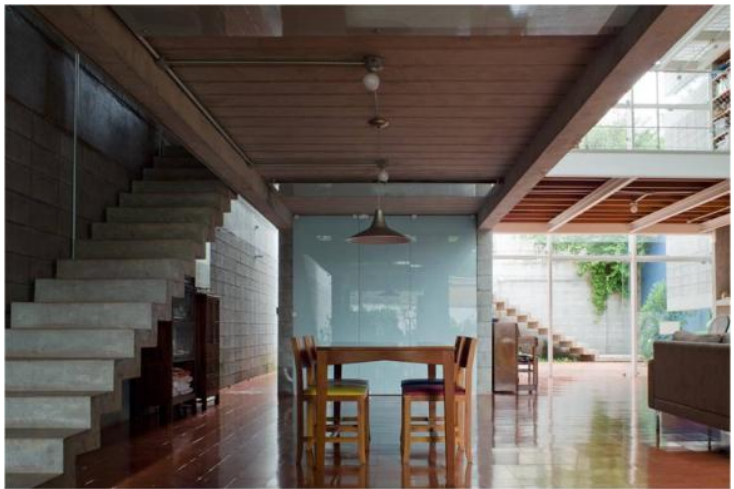

Fig.32 - Residência no Morro do Querosene Fonte: acervo pessoal do arquiteto 
"Pátio, céu canalizado.

O pátio é o declive pelo qual se derrama o céu na casa".

Jorge Luis Borges

2.2. EDIFÍCIO II:

EDIFÍCIO INSTITUCIONAL - COORDENADAS 1549’48"S, 5209’26" O

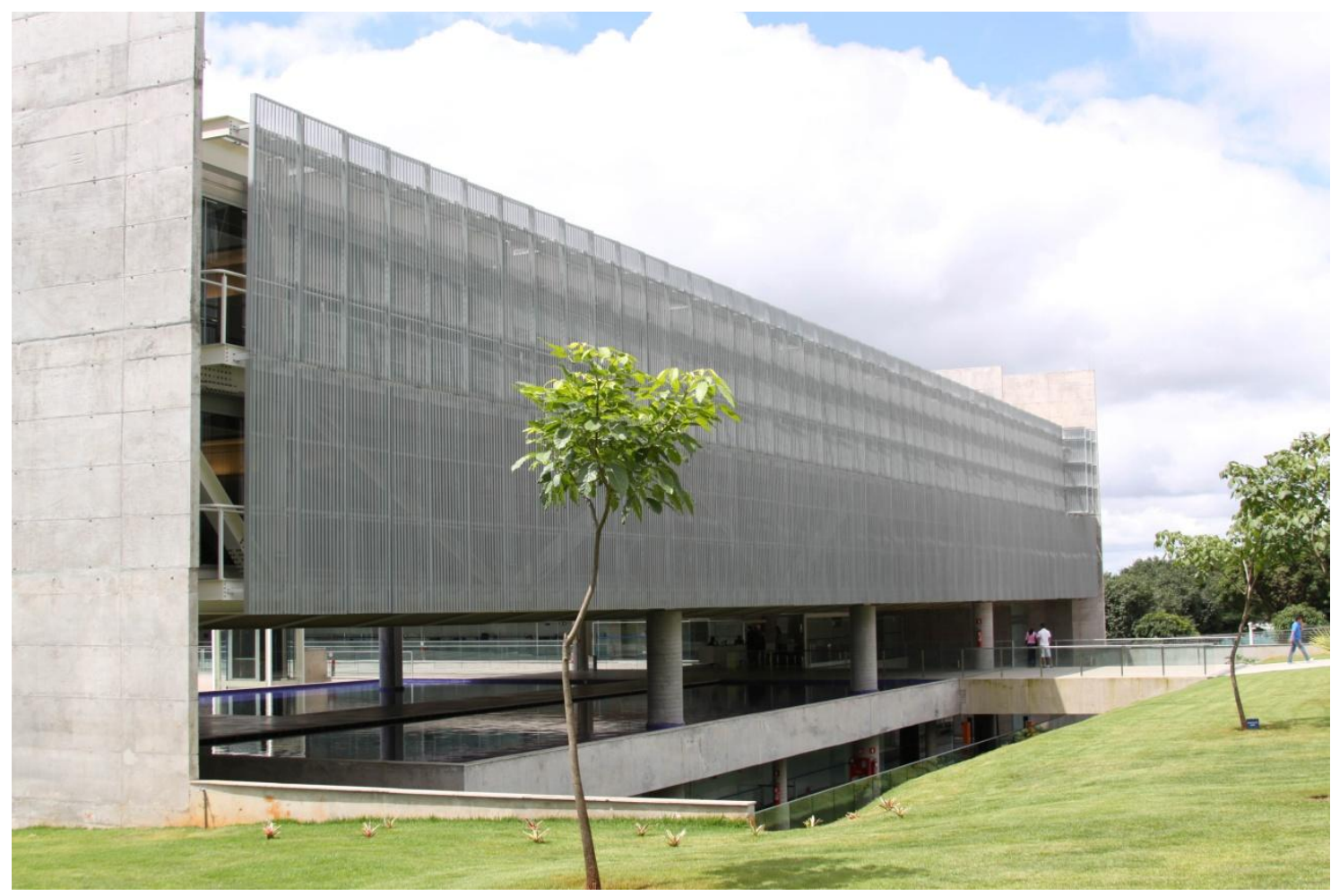

Fig. 33 - Edifício Institucional em Brasília Fonte: acervo pessoal da autora

\subsubsection{Localização}

O edifício de sete pavimentos, sede do Serviço Brasileiro de Apoio às Micro e Pequenas Empresas - SEBRAE Nacional, com área de 25.000,00m2, está localizado na Avenida L2, na Asa Sul, em Brasília, em um terreno com área de 10.000,00m2. O projeto arquitetônico foi realizado em 2008 e a conclusão da obra aconteceu em 2010. 


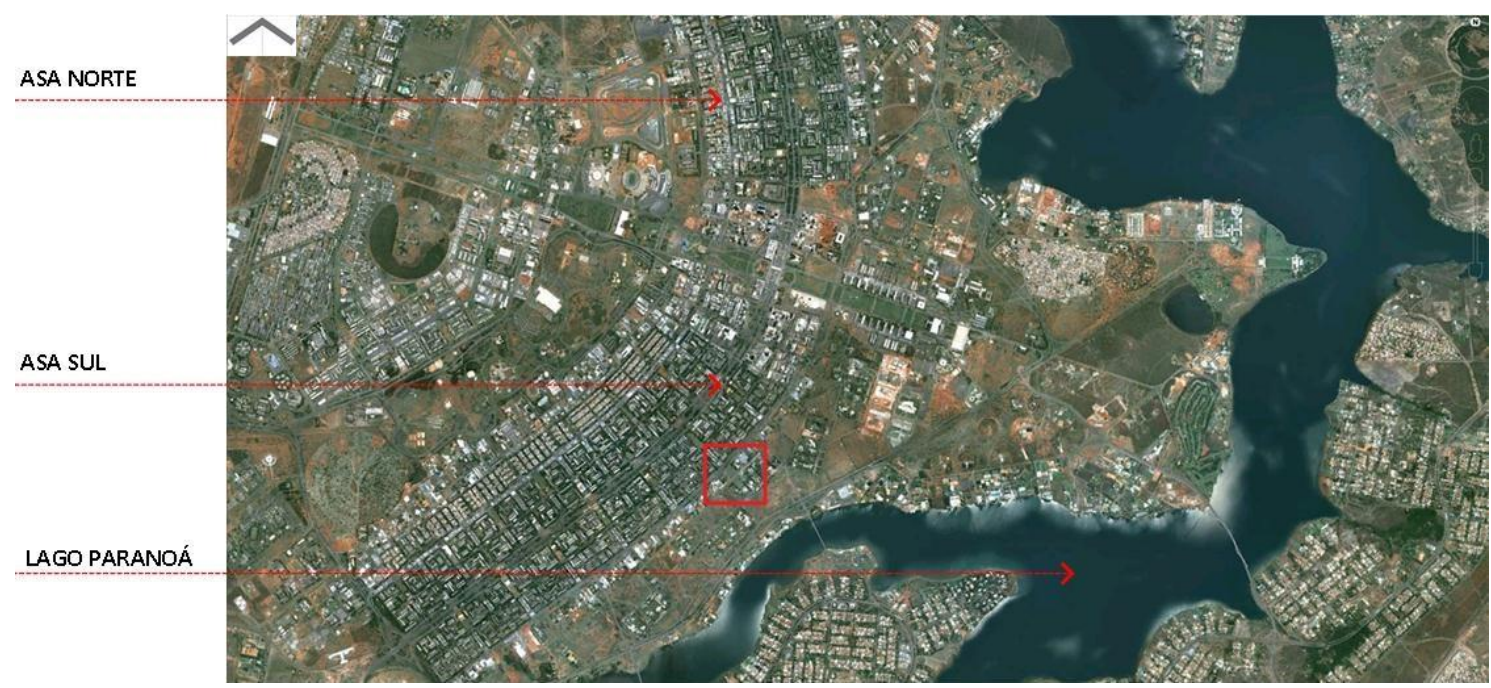

Fig.34 - Situação Edifício SEBRAE em Brasília Fonte: Google Earth

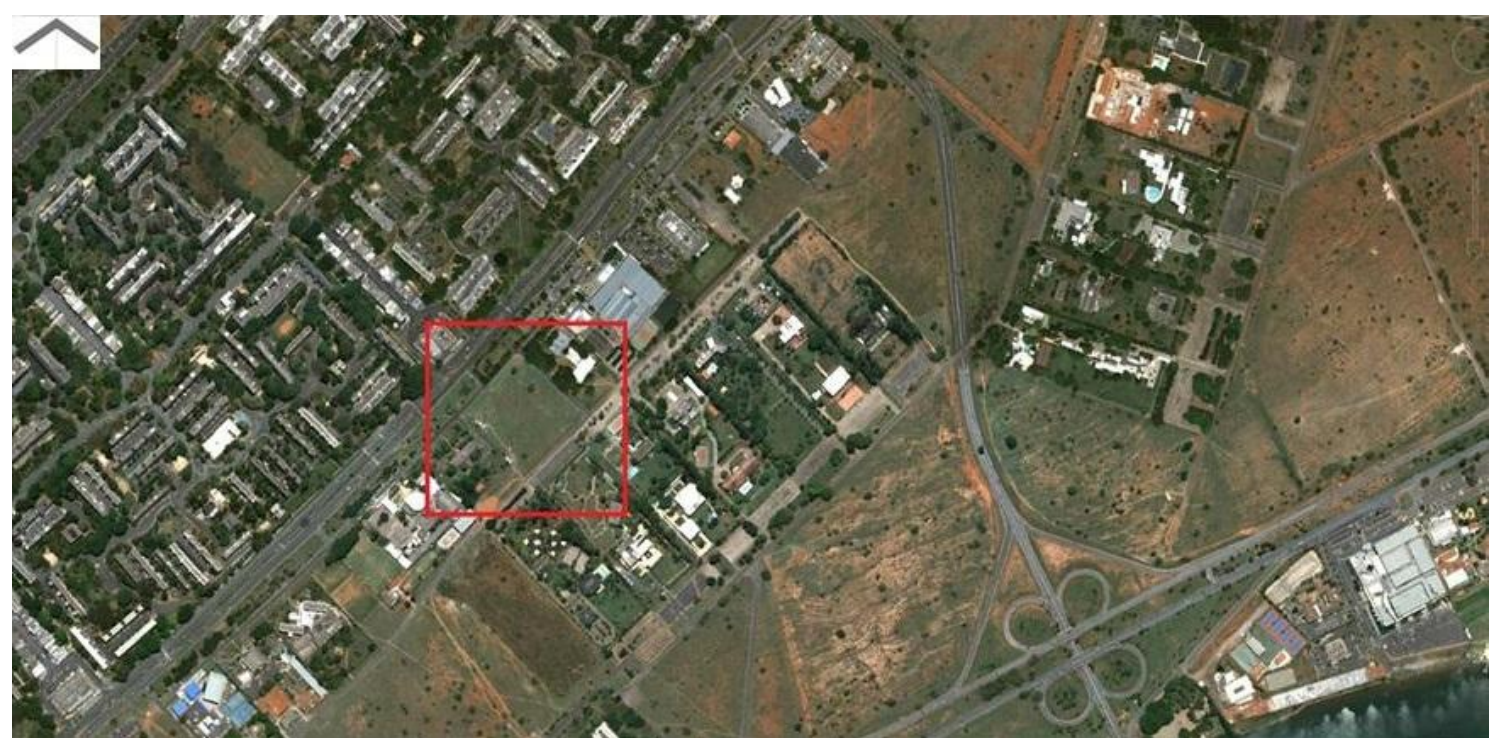

Fig.35 - Situação Edifício SEBRAE em Brasília Fonte: Google Earth 


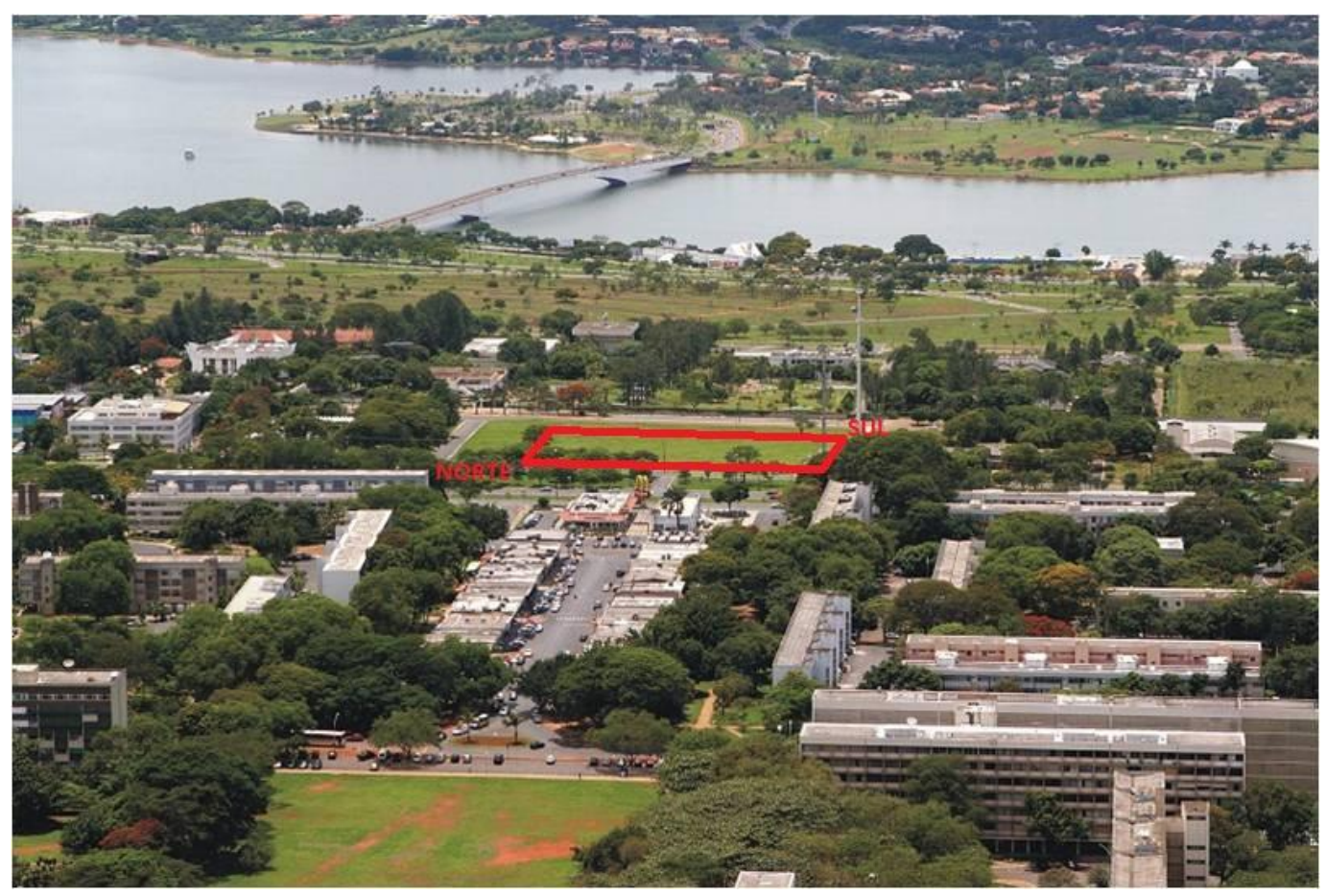

Fig.36 - Situação Edifício SEBRAE em Brasília Fonte: acervo pessoal do arquiteto

\subsubsection{Equipe Técnica}

Projeto de Arquitetura: Álvaro Puntoni, Luciano Margotto Soares, João Sodré e Jonathan Davies

Colaboradores: André Nunes, Rafael Murollo, Julia Valiengo e Isabel Nassif Maquete: José Paulo Gouveia, Fabio Gionco e Gabriel Manzi

Paisagismo: Fernando Chacel e Sidney Linhares

Instalações Hidráulicas e Elétricas: PHE Engenharia de Projetos Hidráulicos e Elétricos

Estrutura: Kurkdjian \& Fruchtengarten

Ecoeficiência: Luiz Carlos Chichierchio, Juliette Haase de Azevedo e Ambiental Consultoria

Painel Artístico: Ralph Gehre

Construção: Termoeste S/A 


\subsubsection{Breve histórico}

O edifício sede do SEBRAE Nacional, em Brasília, nasceu da necessidade por parte da instituição em atender à demanda de espaço físico, a fim de promover uma reestruturação interna com o desenvolvimento de uma nova cultura organizacional e corporativa.

Para tanto, foi promovido um concurso público para o Projeto de Arquitetura, com abrangência nacional, em parceria com o Instituto dos Arquitetos do Brasil - Departamento do Distrito Federal. O projeto desenvolvido pelos arquitetos Álvaro Puntoni, Luciano Margotto Soares, João Sodré e Jonathan Davies foi o escolhido dentre os cento e quinze trabalhos apresentados.

\subsubsection{Estudo analítico do edifício: a implantação}

Com a intenção de propor um espaço público que desse continuidade ao conceito das superquadras da cidade, o partido adotado atende às condicionantes urbanísticas de Brasília e ao caráter da arquitetura que se pretendia para a nova sede do SEBRAE Nacional.

Um conjunto arquitetônico desenvolvido ao redor de uma praça central para onde convergem todos os fluxos e onde ocorrem as atividades públicas foi a proposta apresentada pelos arquitetos. Devido ao desnível natural do terreno entre a via de acesso ao edifício e a via nos fundos do terreno, as partes do conjunto arquitetônico foram dispostas de maneira a concentrar as atividades correlatas, e tal gesto permitiu que a praça central ocorresse em dois níveis: um no nível de acesso ao edifício e outro em um nível inferior.

O acesso de pedestres ao edifício ocorre por uma rampa ao nível da rua - térreo superior - enquanto o acesso ao térreo inferior se dá através de escada e elevadores localizados na praça central e através de rampa para veículos eventuais.

O conjunto faz face para três vias e, devido à sua configuração espacial, cada uma das faces do conjunto tem uma orientação. 


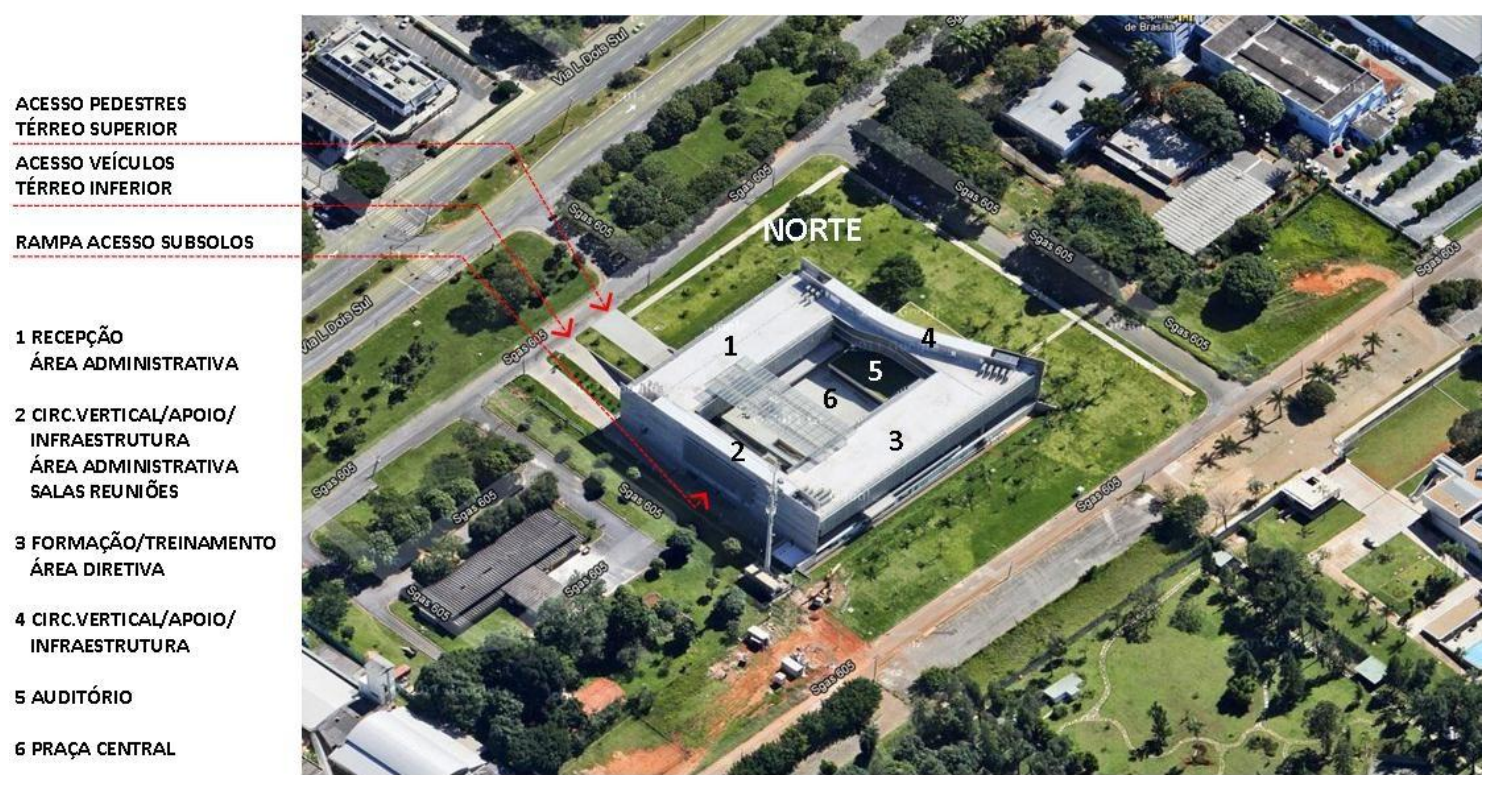

Fig.37 - Implantação Edifício SEBRAE em Brasília Fonte: Google Maps

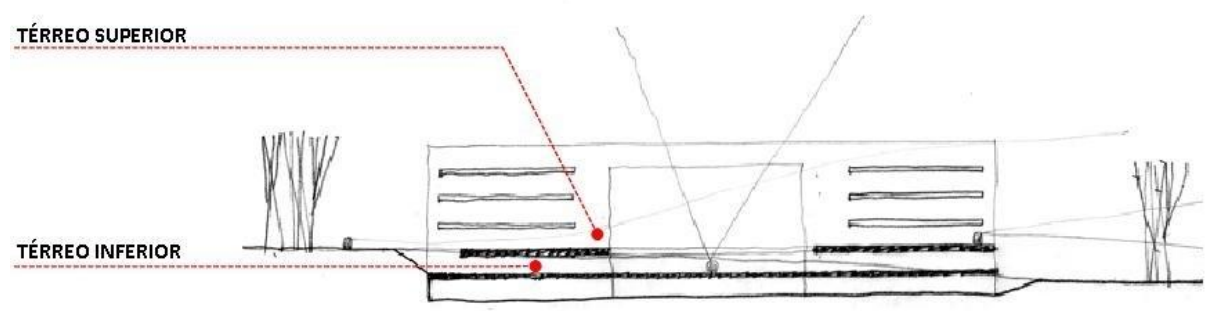

Fig.38 - Implantação Edifício SEBRAE em Brasília Fonte: acervo pessoal do arquiteto

\subsubsection{Composição espacial}

A praça central é a grande área organizadora e articuladora dos espaços no edifício. $\mathrm{A}$ definição dos eixos principais permitiu a distribuição do programa e a setorização das atividades. Dois volumes destinados aos serviços: circulação vertical, apoio e infraestrutura estão colocados em extremidades opostas do conjunto, delimitando o grande vazio. 


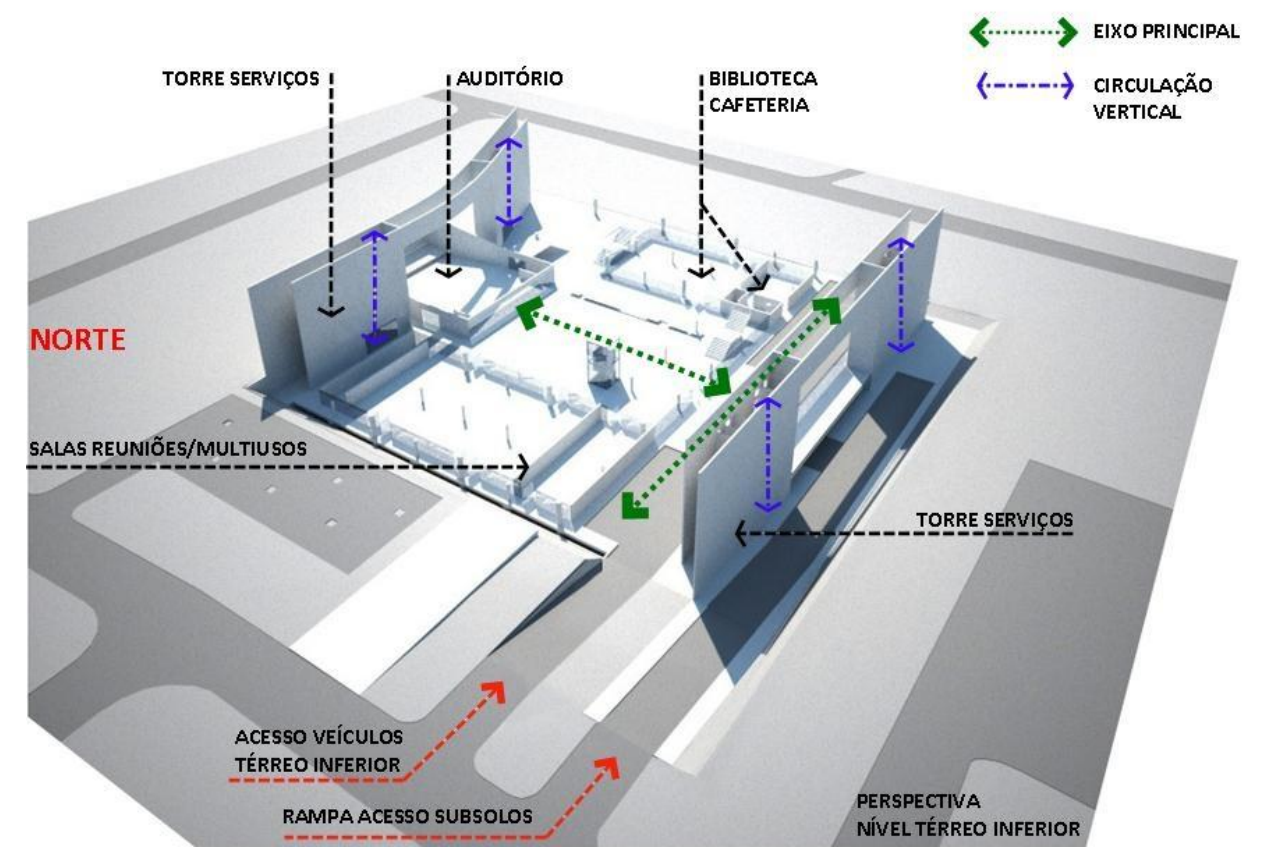

Fig.39 - Perspectiva nível térreo inferior Edifício SEBRAE em Brasília Fonte: acervo pessoal do arquiteto

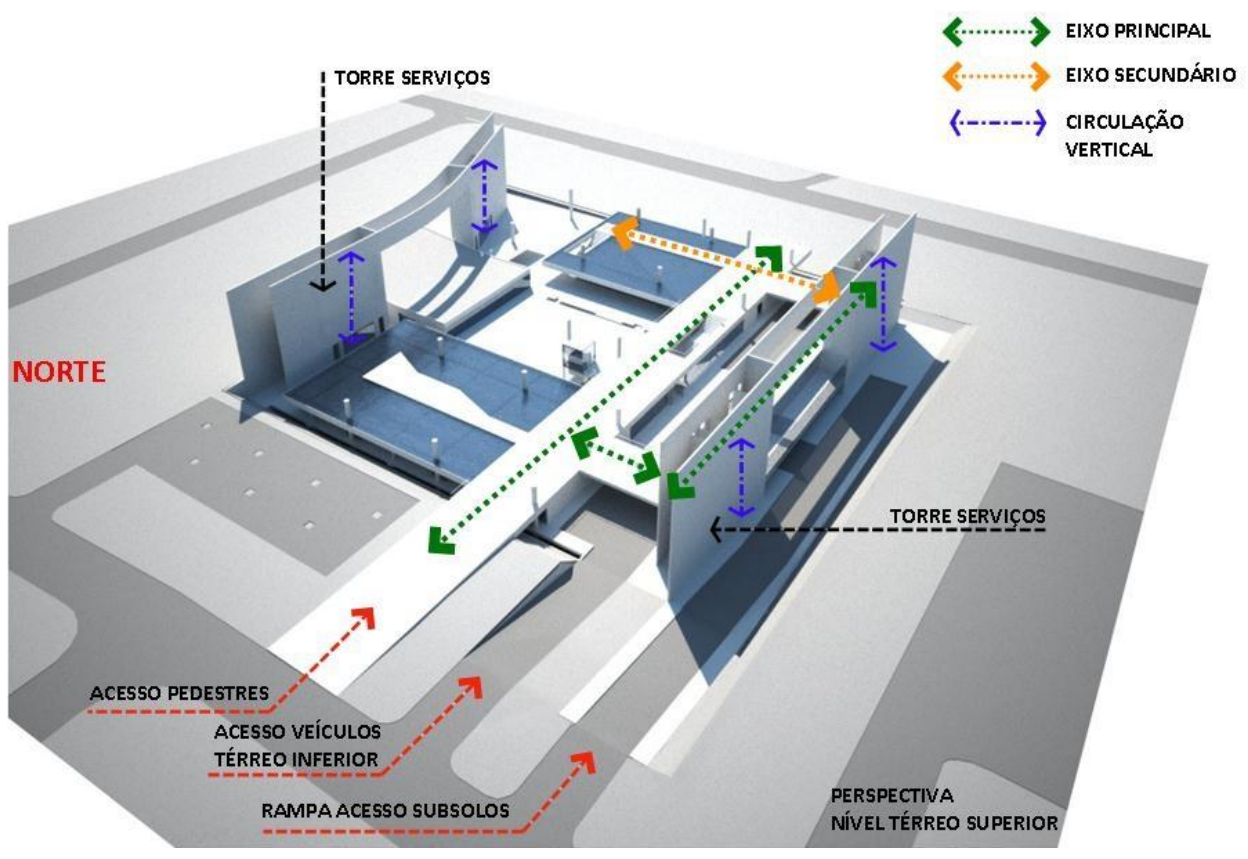

Fig. 40 - Perspectiva nível térreo superior Edifício SEBRAE em Brasília Fonte: acervo pessoal do arquiteto 
Tanto no nível do térreo inferior quanto no térreo superior estão concentradas as atividades coletivas que recebem público externo: auditório, salas de reuniões, salas de multiuso, biblioteca, cafeteria, recepção e a praça central. Os níveis superiores, sob pilotis, concentram as funções administrativas e diretivas da instituição. Os escritórios, divididos em dois blocos, estão interligados por passarelas suspensas de concreto que permitem a visualização por parte do usuário, tanto da praça interna quanto de áreas externas ao prédio. As garagens e as atividades administrativas relacionadas a serviços, infraestrutura e manutenção predial estão localizadas nos dois níveis de subsolo.

Dois espelhos d'água no nível do térreo superior contribuem para amenizar o clima seco da cidade, pois através da ventilação cruzada, a umidade é conduzida para as demais áreas do edifício.

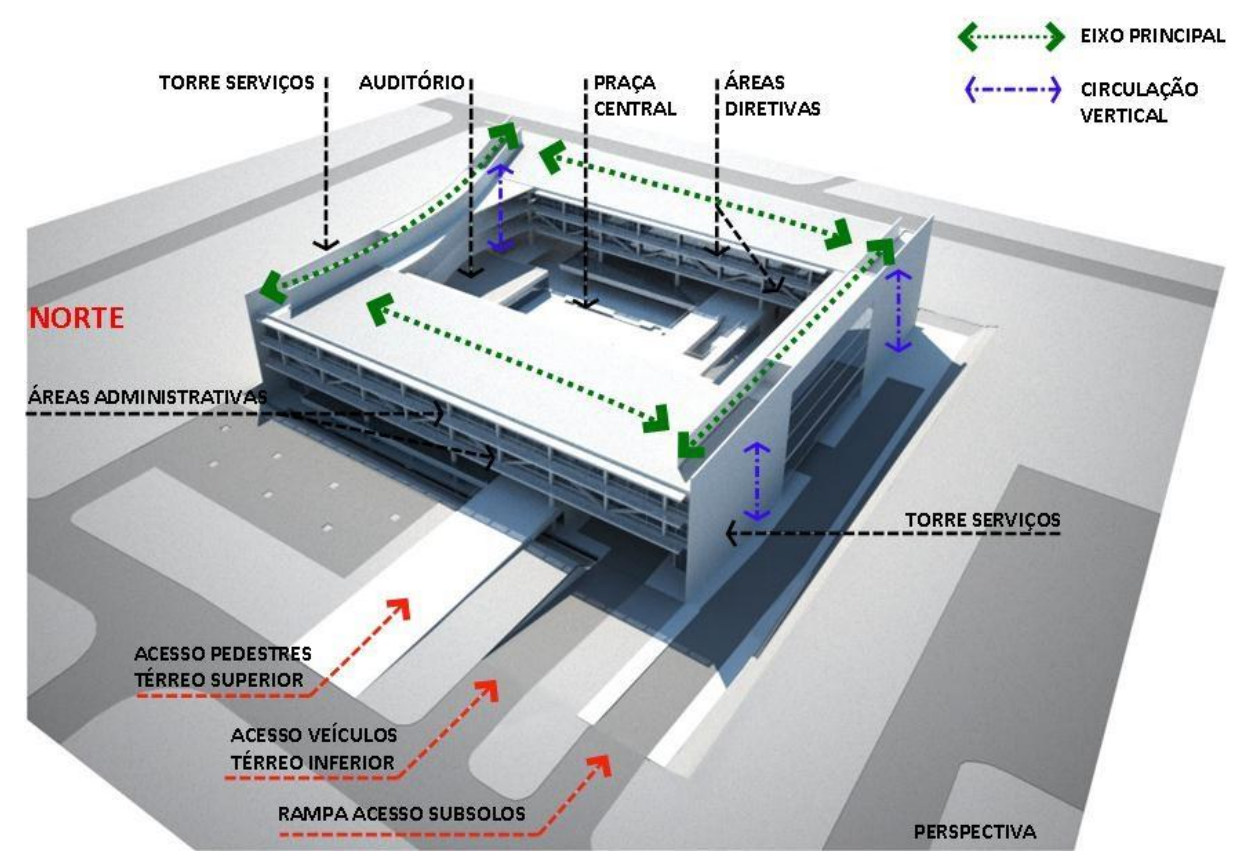

Fig.41 - Perspectiva Edifício SEBRAE em Brasília Fonte: acervo pessoal do arquiteto

2.2.6. Materiais e cores

O edifício possui estrutura mista em concreto aparente e aço com pintura branca. As estruturas das torres de serviço dos subsolos, do térreo inferior e do térreo superior foram executadas em concreto moldado in loco com lajes em concreto protendido. Nos dois 
pavimentos de escritórios, a estrutura é em aço, composta por duas treliças longitudinais, distantes dezoito metros entre si, travadas por pórticos transversais também metálicos. As passarelas de concreto que interligam os blocos de escritórios são fixadas através de pendurais travados às vigas em concreto das torres de serviço.

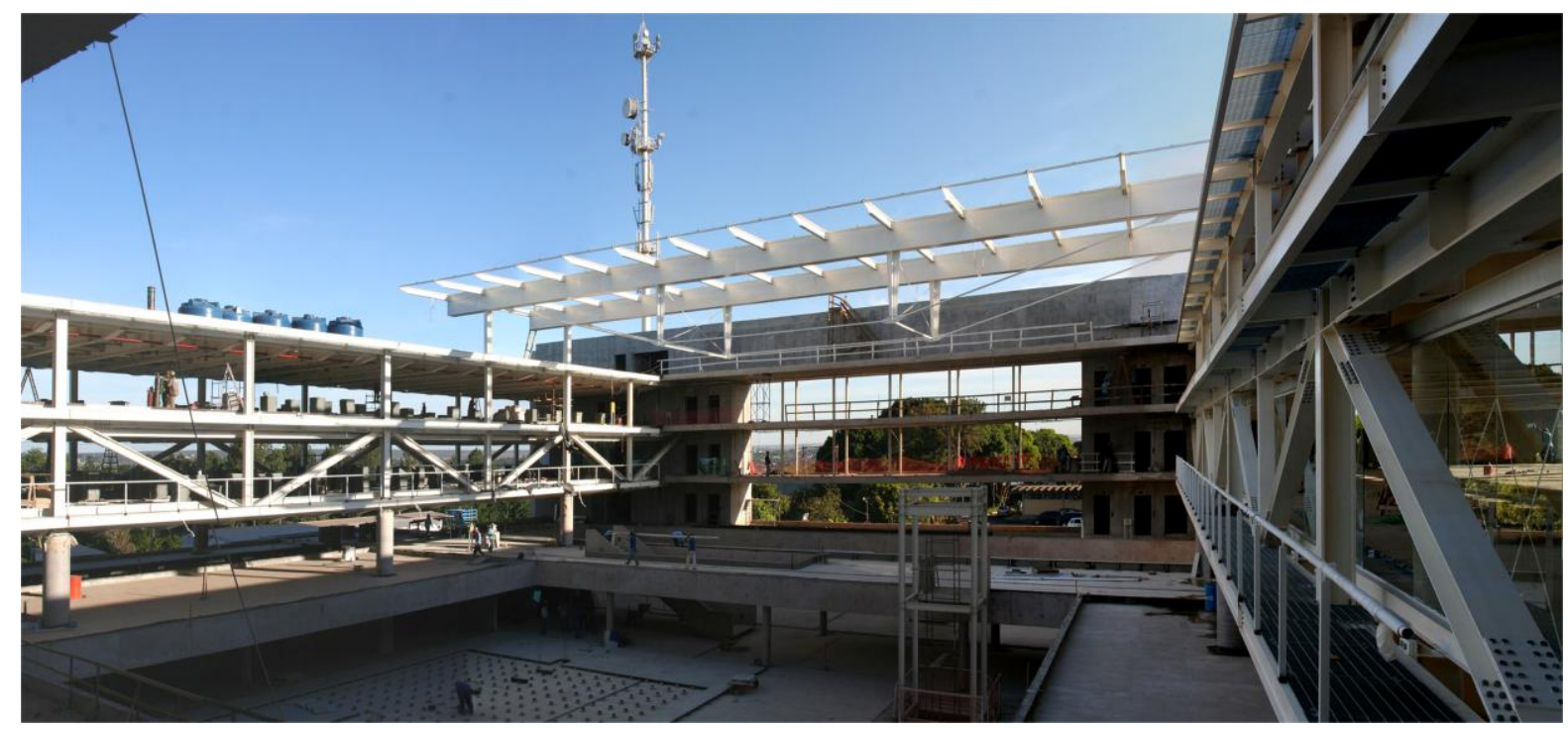

Fig.42 - Edifício SEBRAE em Brasília Fonte: acervo pessoal do arquiteto

Apoiada sobre a laje de cobertura do último pavimento, uma estrutura metálica, coberta com vidro serigrafado, cobre o eixo principal de circulação do conjunto.

O fechamento dos pavimentos entre as lajes acontece através de esquadrias de alumínio e vidro laminado translúcido em todo o pé direito. Externamente à vedação, uma estrutura metálica sustenta os brises metálicos móveis que revestem as fachadas. O brise é modulado, composto por tela metálica e a sua movimentação acontece a cada três módulos. O acesso aos brises se dá através de uma passarela metálica posicionada entre a vedação do edifício e a tela metálica. 

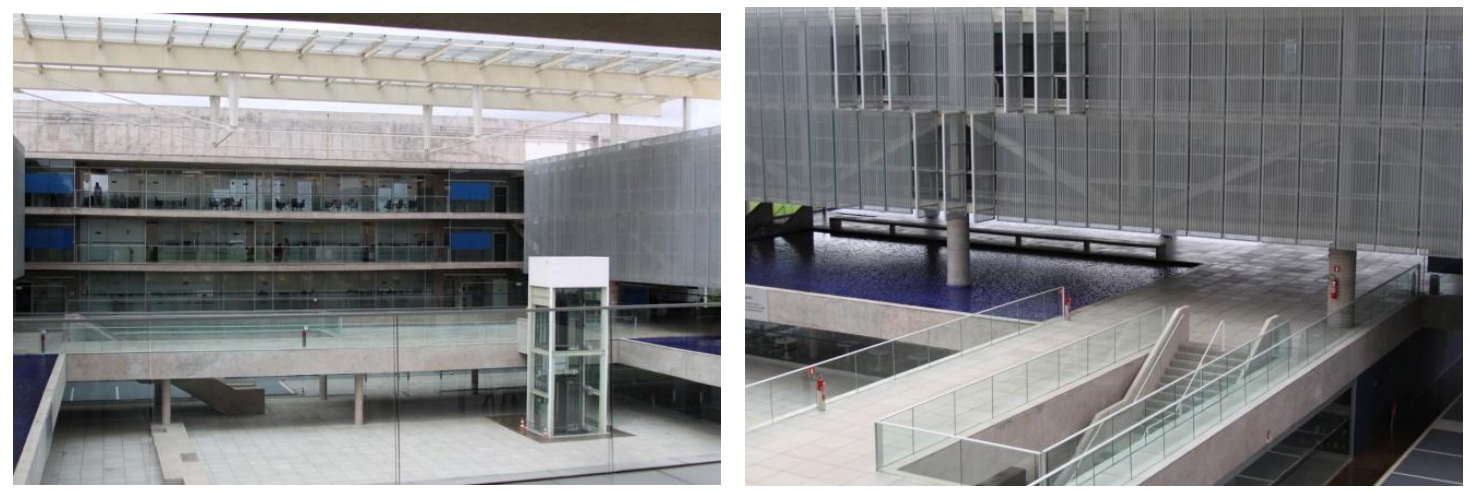

Fig. 43 - Edifício SEBRAE em Brasília Fonte: acervo pessoal da autora

As cores naturais dos materiais e acabamentos do edifício contrastam com o verde dos jardins que estão em seu entorno imediato e com a grama sobre a laje de cobertura do auditório; com o azul no céu, das pastilhas que revestem os espelhos d'água e do painel de azulejos do auditório, intitulado Gavião, feito pelo artista plástico Ralph Gehre.

\subsubsection{Iluminação natural: aspectos funcionais e aspectos subjetivos}

O partido arquitetônico privilegia a questão do conforto no ambiente construído. Aspectos como a implantação, a praça central, a existência da ventilação cruzada que acontece tanto ao nível do térreo superior quanto inferior, a presença de espelhos d'água, a vegetação na cobertura do auditório e o espaço intersticial existente entre as vedações e os brises metálico garantem uma melhor refrigeração do edifício.

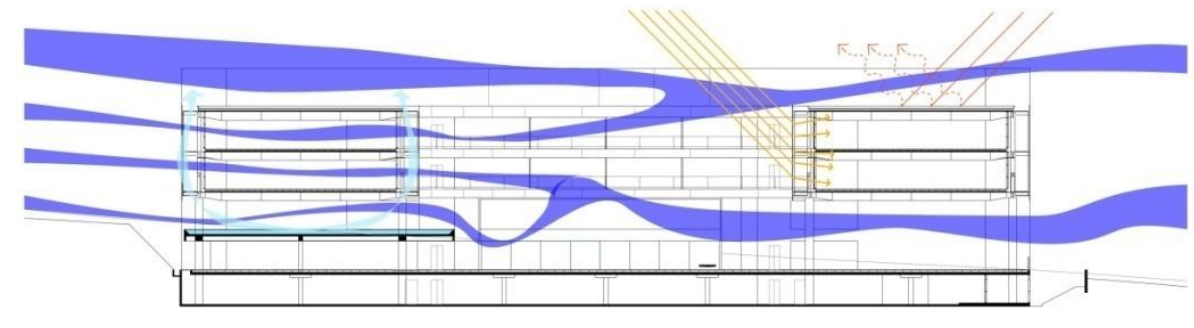

Fig.44 - Corte esquemático Edifício SEBRAE em Brasília Fonte: acervo pessoal do arquiteto 
Um corte feito no terreno, longitudinalmente à via de acesso ao edifício, possibilitou que a iluminação natural, através de um fosso de luz no nível do térreo inferior, chegasse aos dois níveis de subsolo. Outro corte longitudinal à via dos fundos do terreno permitiu também a iluminação natural no segundo nível de subsolo.

O revestimento do piso - epóxi - das áreas de estacionamento reflete a luz do dia que incide sobre ele, gerando ofuscamento.

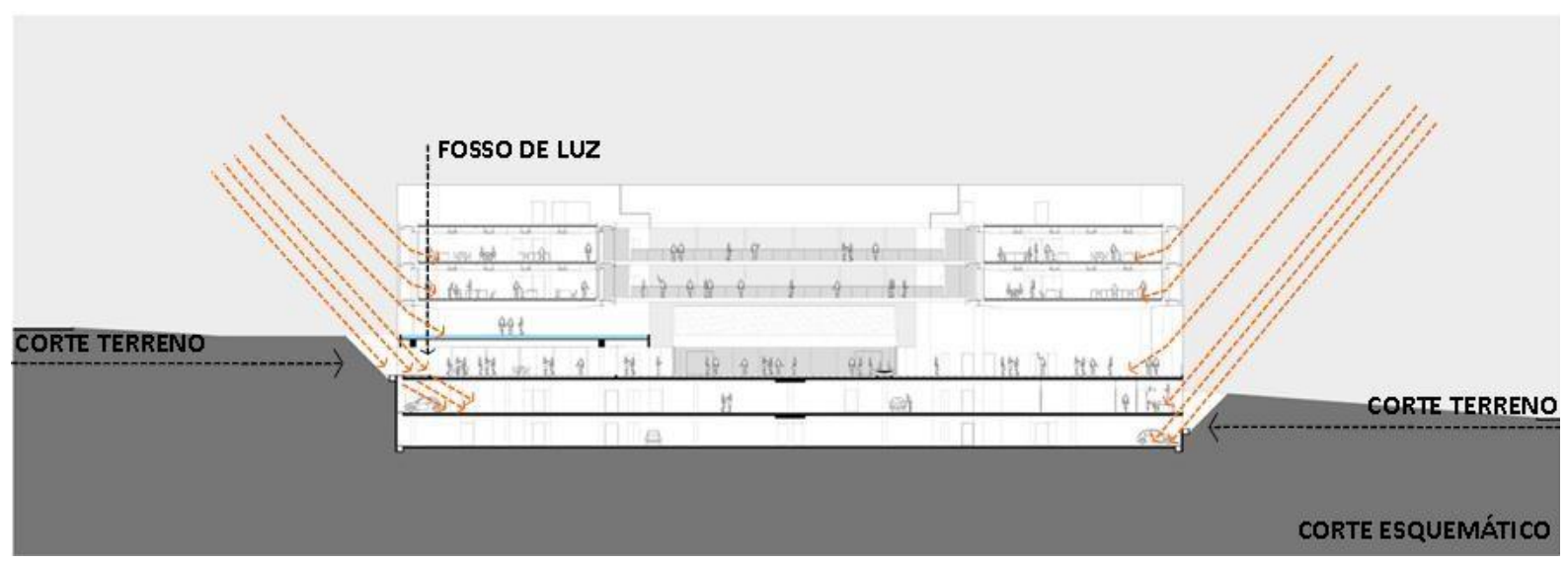

Fig.45 - Corte esquemático Edifício SEBRAE em Brasília Fonte: acervo pessoal do arquiteto
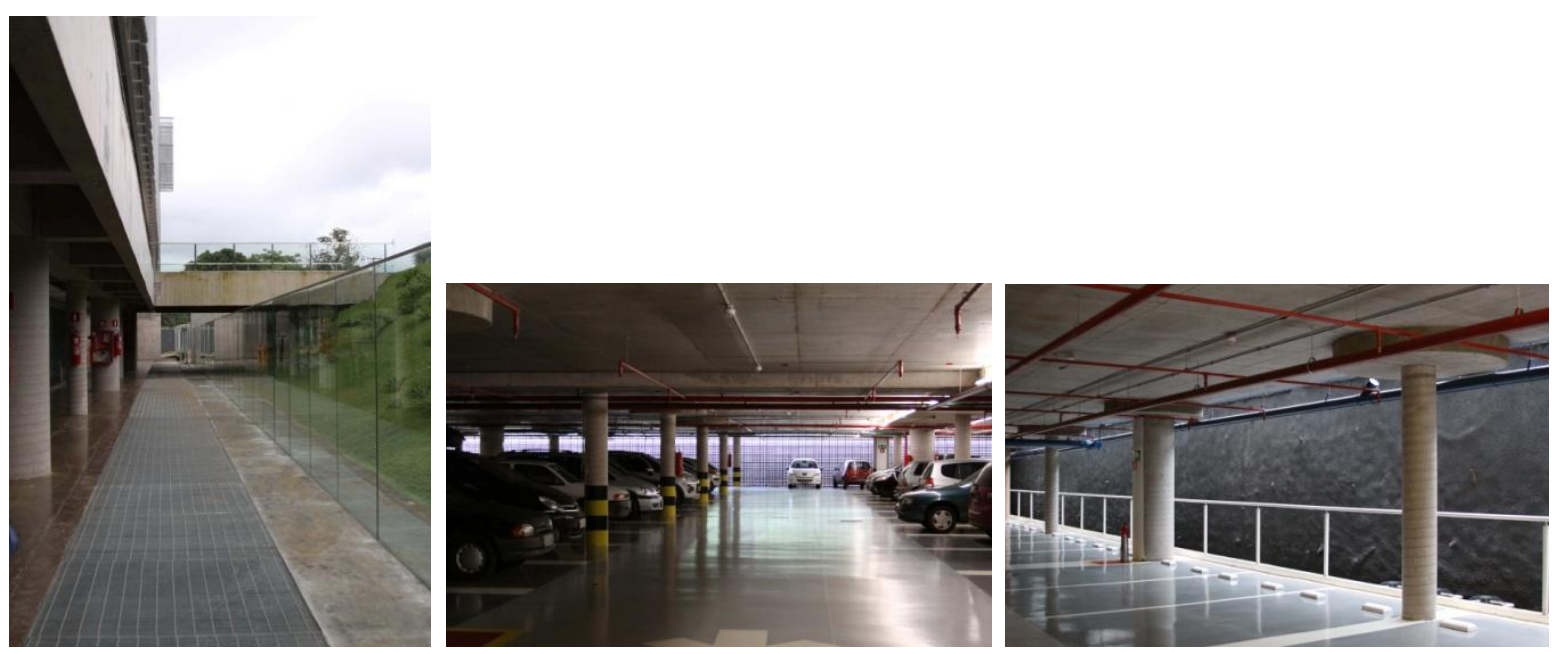

Fig.46 - Subsolo 1 e 2 Edifício SEBRAE em Brasília Fonte: acervo pessoal da autora

No nível térreo inferior, a vedação das salas multiusos, auditório, biblioteca, cafeteria e todas as áreas administrativas é feita em vidro laminado translúcido em todo o pé direito. A posição recuada da vedação em relação à estrutura possibilitou a existência de uma marquise que protege o usuário da chuva como também do sol. A dimensão desse recuo 
ocasionou uma área maior de sombra para os espaços destinados às salas de multiuso e sala de reuniões, provocando contraste de luminosidade nos espaços internos. Assim como nos estacionamentos dos subsolos, o revestimento do piso - epóxi - da área destinada ao eventual embarque e desembarque de passageiros, no térreo inferior, permite que esta se torne uma grande superfície reflexiva da luz do dia, gerando ofuscamento.

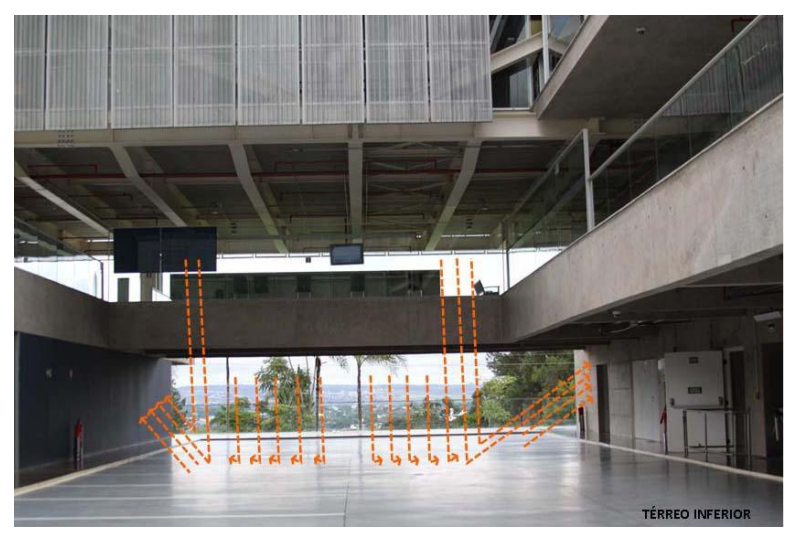

Fig.47 - Térreo inferior Edifício SEBRAE em Brasília Fonte: acervo pessoal da autora

As áreas de trabalho localizadas nos volumes superiores são totalmente permeáveis à luz do dia, por possuírem aberturas voltadas tanto para o exterior quanto para a praça central, promovendo a integração do espaço interno com o externo. Internamente às aberturas, nos espaços das áreas administrativa e diretiva, telas solares de proteção foram instaladas posteriormente à ocupação do edifício, devido ao ofuscamento provocado pela luminosidade nas telas dos monitores.

As fachadas externas do edifício, com exceção da fachada voltada para a rua lateral, onde está localizado o auditório, cuja orientação é nordeste, receberam o brise metálico. 0 brise em tela metálica foi proposto também para a fachada sudoeste, onde não se tem incidência direta do sol, a fim de garantir maior privacidade aos espaços internos pelo fato de fazer divisa construída no terreno adjacente. Apenas os volumes das áreas diretiva e administrativa receberam o brise em suas faces internas, voltadas para a praça central, cujas orientações são nordeste e sudoeste, respectivamente. 


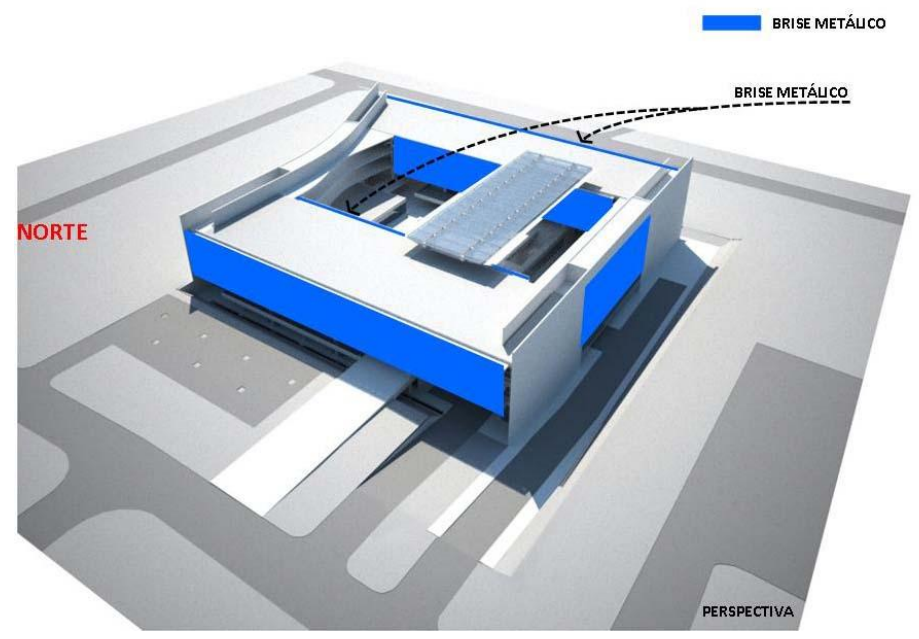

Fig.48 - Edifício SEBRAE em Brasília Fonte: acervo pessoal do arquiteto

O acionamento do brise se dá manualmente, conforme solicitação dos usuários dos espaços, e o seu acesso é garantido através de uma passarela metálica em cada piso, entre a vedação dos pavimentos e a sua estrutura de fixação.
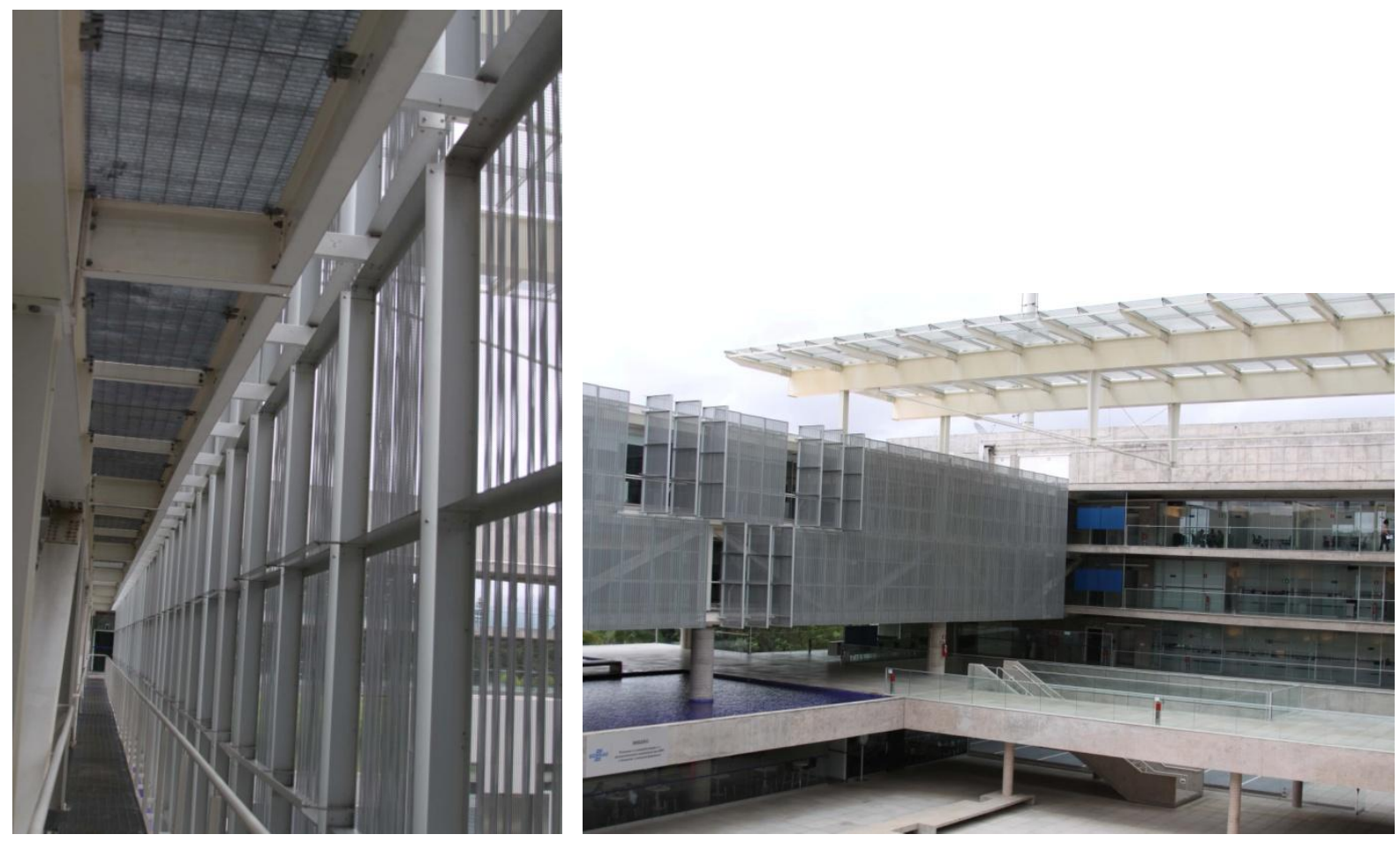

Fig.49 - Edifício SEBRAE em Brasília Fonte: acervo pessoal da autora 


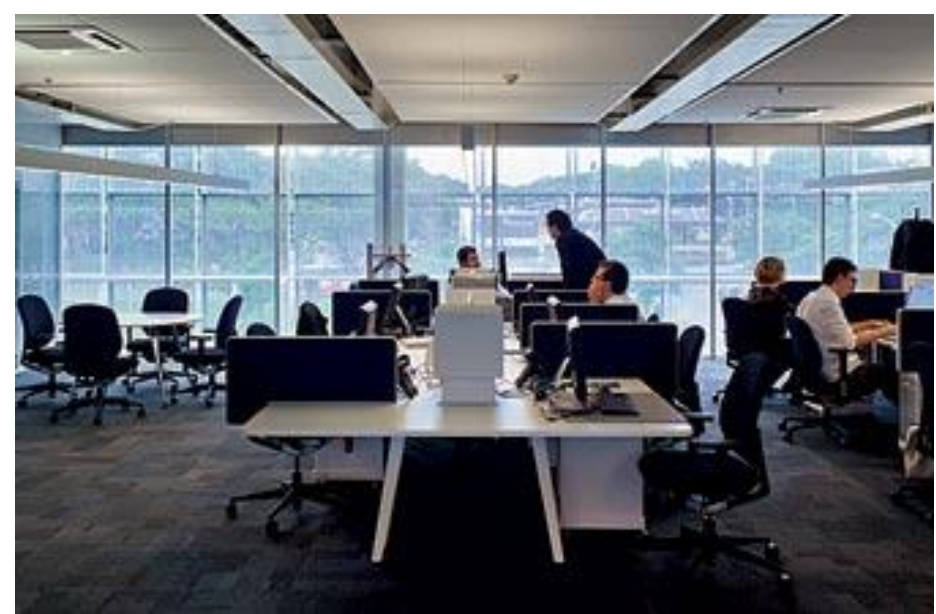

Fig.50 - Área administrativa Edifício SEBRAE em Brasília Fonte: http://www.arcoweb.com.br/arquitetura/alvaro-puntoni-luciano-margotto-soares-joao-sodrejonathan-davies-sede-sebrae-18-05-2011.html

..."Mas aqui não me sinto só, nem nua.

Ao vento, sim. Todo o ar mais puro do cerrado me atravessa.

Pretendo à deriva. Mas, aos poucos, o espaço me conduz, claro como o pensamento.

Respiro a grande praça central, e logo compreendo: os escritórios suspensos longitudinalmente; os automóveis abaixo da rua; o auditório anunciado pela única parede curva do projeto.

$E$, se aqui reconheço uma malha estrutural, que reaviva a modulação latente do entorno, ali quase a perco, diante da instabilidade dos fartos espelhos d'água, em que o tempo - o tempo tão casto de Brasília - se desalinha e, por pouco, não se deixa levar pela dança flutuante dos aguapés.

Percorro o edifício lentamente, equilibrando-me sobre seus eixos, horizontais e verticais, e explorando a topografia redefinida em arquitetura.

Do chão, alcanço varandas, de onde a visão se amplia.

Vejo o céu.

Vejo a cidade, vejo além.

Brasília tem 50 anos.

E este edifício desencobre sua condição primária: o vazio".

(NOBRE, 2010, p.56)

O projeto destaca-se pela qualidade formal, espacial e construtiva. O edifício utilizase de referências para estabelecer um diálogo com a cidade, seja através da fachada

\footnotetext{
${ }^{8}$ Texto de Ana Luiza Nobre, arquiteta, historiadora e professora do Curso de Arquitetura e Urbanismo da PUCRio em Nova sede SEBRAE Nacional, 2010.
} 
levemente curva que se reporta às curvas dos edifícios de Oscar Niemeyer ou do Plano Piloto de Lucio Costa, seja através da releitura do repertório da arquitetura moderna.

As grandes áreas de circulação por onde se avista o horizonte da cidade, os espaços integrados que contribuem para a aproximação das pessoas e a luz que atravessa o edifício são elementos significativos do projeto.

A superfície de vidro serigrafado que cobre parte do grande vazio central, onde a luz do dia é canalizada e distribuída, traça, ao longo do dia, desenhos de luz e sombra no piso, estabelecendo um diálogo com os panos abertos ou fechados dos brises.

Os gestos projetuais precisos que ora negam, ora admitem a matéria, permitem ao observador a nítida percepção de contrastes gerados pela abundante luz do dia que permeia todo o espaço: contrastes entre luz e sombra, cheios e vazios, transparências e opacidades, a presença ou a ausência de cor.

Os brises, além de cumprirem a função de proteger as fachadas contra a incidência direta da luz do dia, dançam em movimentos ao se abrir e fechar, seguindo a música dessa mesma luz ao longo das horas do dia.

O espaço criado pelos arquitetos ocasionou não apenas uma mudança física para os seus ocupantes, como contribuiu significativamente para a mudança de atitudes entre os colaboradores da instituição ao possibilitar uma melhor interação entre as equipes de trabalho.

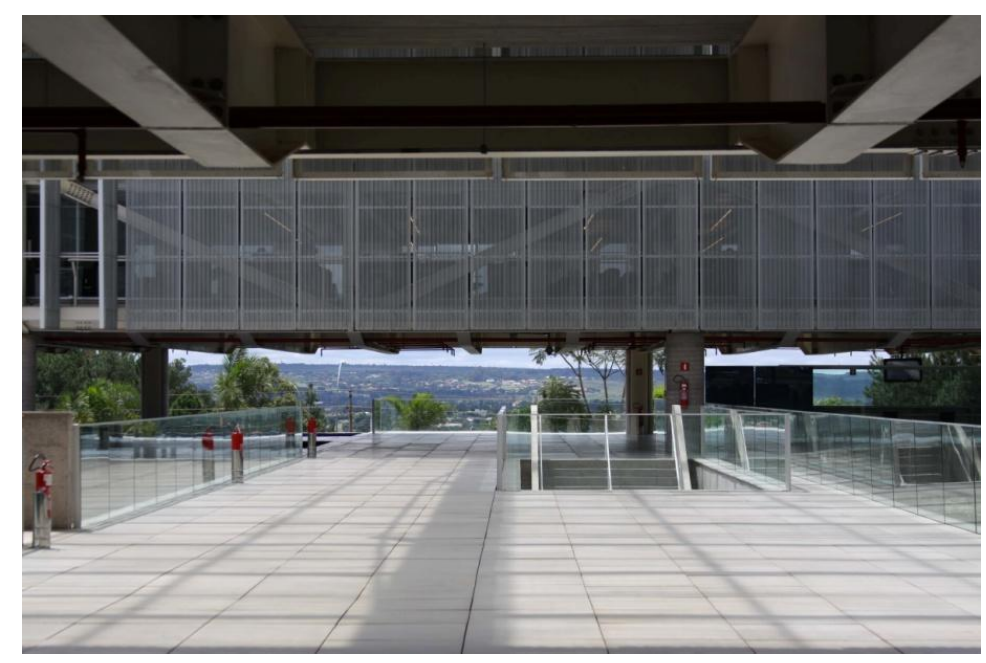

Fig.51 - Edifício SEBRAE em Brasília Fonte: acervo pessoal da autora 


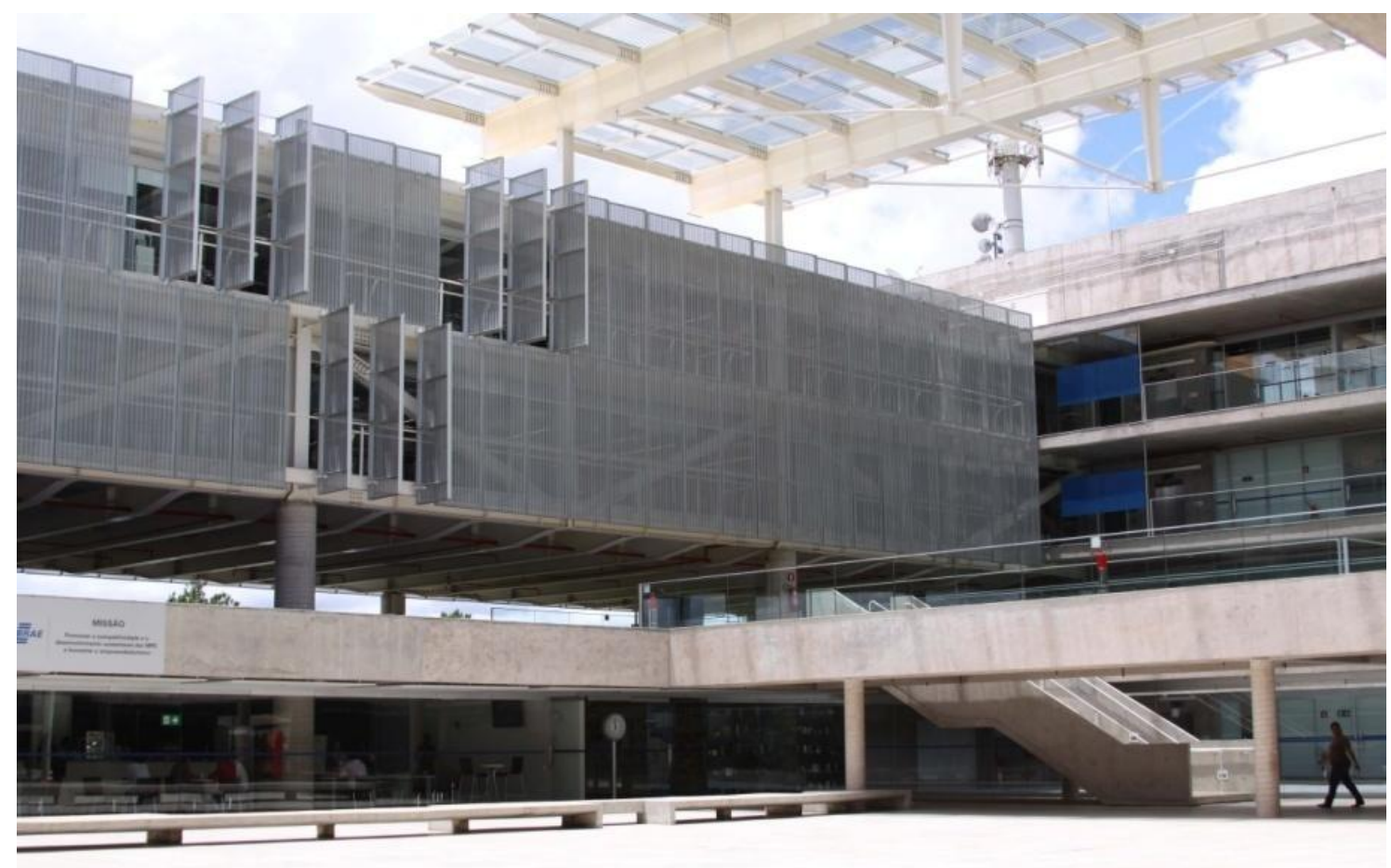

Fig.52 - Edifício SEBRAE em Brasília Fonte: acervo pessoal da autora 
“A arquitetura ocorre no encontro de forças interiores e exteriores de uso e espaço. Essas forças interiores e ambientais são, simultaneamente, gerais e particulares, genéricas e circunstanciais. A arquitetura como parede entre o interior e o exterior converte-se no registro espacial dessa resolução e em seu drama. E, ao reconhecer a diferença entre o interior e o exterior, a arquitetura abre a porta, uma vez mais, para um ponto de vista urbanístico"

(VENTURI, 2004, pg.119)

\section{CAPÍTULO III}

\section{A VISÃO DA LUZ DO DIA PARA O ARQUITETO LUCIANO MARGOTTO SOARES}

O arquiteto Luciano Margotto Soares é formado pela Faculdade de Arquitetura e Urbanismo da Universidade de São Paulo - FAUUSP, em 1989, e concluiu o Mestrado, em 2001, nesta mesma instituição. É professor de Projeto na Universidade Presbiteriana Mackenzie e também na Escola da Cidade desde 2002. Participou com os arquitetos Sergio Luiz Salles Souza e Marcelo Luiz Ursini do escritório Núcleo de Arquitetura de 1988 a 2010.

Luciano Margotto une a produção de uma arquitetura comprometida com a qualidade da cidade e do edifício e o exercício acadêmico e pesquisa. A visão de que a arquitetura primordialmente deve atender aos interesses da população é expressa por Ursini, ex-integrante do escritório Núcleo de Arquitetura:

\footnotetext{
“Na construção de nossas cidades, as noções de espaço público e de espaço privado têm se definido pelos valores de uso e posse, mantendo, portanto, uma relação de oposição. A arquitetura, porém, deveria ser entendida sempre como uma ação de interesse público, onde o desenho de espaços entre estas duas categorias de espaço permitisse a fruição da cidade pelos cidadãos que optaram viver em uma cidade aberta. Que espaços são esses e que papel têm desempenhado na construção de uma cidade que possam inscrevê-la em uma idéia de modernidade: a convivência das diversidades em um mesmo espaço democrático e franco". (URSINI, 2004, p.1)
}

Impossível falar sobre o pensamento do arquiteto a respeito de arquitetura, sem trazer para o tema a FAUUSP. A partir da entrevista feita com Luciano Soares Margotto, percebe-se nitidamente que a sua matriz genética é a arquitetura moderna. A visão da questão pública da arquitetura, em todos os projetos, foram lições aprendidas a partir das 
posturas dos professores de Projeto, na FAUUSP. Lições que o arquiteto traz como pano de fundo para seu trabalho.

Por possuir a preocupação com a coisa pública, com a cidade e os seus cidadãos, o arquiteto busca sempre a inclusão de aspectos sociais e culturais na construção e organização dos lugares. O interesse pela questão pública da arquitetura se manifesta através da formalização no desenho da cidade, no desenho de um pavimento térreo e também na vontade de deixar a cidade e a arquitetura, de fato, como uma ação de interesse público.

Luciano Margotto defende o posicionamento de que o espaço não pode ser analisado ou compreendido como uma simples entidade física, separado do tempo histórico, dos aspectos sociais de comunidades locais e da sociedade como um todo. Existe a preocupação em relacionar o edifício com o contexto histórico, bem como o diálogo com o entorno, ao se estabelecer uma interação com este, e não apenas um contextualismo mimético. 0 mimetismo refere-se à apropriação, no projeto, de elementos contextualizados.

Além dos aspectos anteriormente relacionados, para Margotto, várias outras questões devem ser consideradas ao se projetar: a luz do dia do lugar, os fluxos, a estrutura e a preservação da identidade local.

Ele defende a postura de que a natureza do projeto é holística e que é necessário que o arquiteto tenha uma visão holística da arquitetura. Zanettini (2006) refere-se à arquitetura que representa a contemporaneidade, como uma arquitetura onde cada uma de suas questões deve ser colocada no complexo de conceito humanístico e holístico:

\footnotetext{
“O que existe é a arquitetura, cada vez mais holística e sistêmica, envolvendo todas as áreas de conhecimento. Todas as disciplinas vêm correndo, cada vez mais, para a definição de arquitetura, envolvendo experiência acumulada, evolução científica. Nada se faz hoje na construção civil, seja no âmbito urbano ou da edificação, se não for com base científica. As decisões são apoiadas sobre o que as ciências construíram nas áreas de humanas, biológicas, ambientais, econômicas e exatas. Se a arquitetura não tiver cada uma de suas questões colocadas nesse complexo de conceito humanístico e holístico, ela não representa a contemporaneidade - que é a diferença existente na arquitetura até o período moderno, quando era basicamente unidimensional e se refletia muito em função da estética. Penso que sou um dos primeiros a refletir desta forma, que a transformação será pluridimensional, e não
} 
mais unidimensional. A passagem, que ainda é de forma, estilo ou estética, será uma passagem de dimensão. Antes a questão ambiental tinha pouca importância, pois o homem sempre destruiu o espaço com a postura de tomar posse da natureza. Agora percebemos que não se trata de posse, mas de interação com a natureza. Com isso, começam a mudar profundamente os conceitos. A passagem deste momento para um novo é a visão holística da arquitetura. Esta envolve, de um lado, todo o mundo racional, tudo aquilo que o homem construiu através do conhecimento, que sempre foi evolutivo, sistemático; e, de outro, o mundo sensível, da emoção, invenção, ousadia." (ZANETTINI, 2006, p.12)

A reflexão sobre a luz do dia, como elemento compositivo, é tratada desde o início do processo criativo. Muitas vezes, a luz do dia é pensada antes de seu início, em considerações acerca de experiências prévias, como afirma o arquiteto, dizendo que nenhum projeto parte do zero, e que o projeto é fruto do desenvolvimento de várias ideias que vêm sendo experimentadas.

A forma de utilização da luz do dia como elemento de composição nas obras dos grandes mestres como Louis Kahn, Alvar Aalto e Álvaro Siza, é fonte inspiradora para seus projetos.

“É evidente que a gente tem um gosto, tem uma predileção por esse assunto, gostamos da obra do Louis Khan, como eu estava falando. A gente sempre olhou muito para a obra do Alvar Aalto, da luz desenhada, depois disso o Álvaro Siza. Enfim, muitos arquitetos que, às vezes, não são muito olhados no Brasil. Steven Holl que trabalha com uma luz naqueles desenhos de aquarela que ele faz e depois você vai para a obra e parece que é o próprio desenho, uma reprodução daquele desenho. É fantástico como Steven Holl concebe a luz!" (SOARES, Apêndice digital)

A reverência ao trabalho de Álvaro Siza e a forma como o arquiteto incorpora a luz do dia em seus edifícios, pode ser observada em Soares (2001):

"Se as plantas revelam idéias claras de organização e adaptação ao sítio, são os cortes que apresentam a espacialidade e sua alma: a luz natural. E nesse aspecto, Álvaro Siza já escreveu um capítulo à parte da história da arquitetura: é um escultor da luz". (SOARES, 2001, p.38) 
Como processo de projeto, Luciano Margotto entende que várias tentativas de aproximação ao projeto devem ser feitas para se chegar à definição do partido arquitetônico. Especulações e questionamentos devem ser elaborados para se alcançar um resultado, tendo como discussão fundamental o cerne do projeto.

A metodologia de projeto adotada pelo arquiteto, no que se refere ao projeto com a luz do dia, segue os procedimentos padrão para projetos. Segundo Robbins (1986, p.14), as fases do processo de projeto com a luz são: análise prévia, estudo preliminar, anteprojeto, projeto de execução e execução do edifício. Para o mesmo autor, a análise prévia deve questionar a viabilidade da luz do dia como elemento de composição no projeto arquitetônico, segundo a ilustração abaixo:

\section{A LUZ DO DIA É UMA ALTERNATIVA VIÁVEL PARA O PROJETO?}

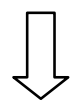

ANÁLISE PRÉVIA

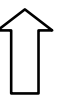

\section{CONSIDERAÇÕES SOBRE O LUGAR}

CONSIDERAÇÕES SOBRE O PROGRAMA

CONSIDERAÇÕES UTILITÁRIAS E ENERGÉTICAS

Como ferramenta auxiliar, o arquiteto utiliza modelos em escala reduzida para análise e compreensão da luz dentro do edifício. As decisões de projeto quanto ao uso da luz do dia são baseadas em reflexões e estudos e não apenas de maneira intuitiva. O pensar na luz do dia e o cuidado com a sua utilização estão incorporados em seu processo de projeto com um requinte e primor que beiram a poesia.

Sua obra não segue regras definidas, pré-concebidas. Ela abre-se a cada condição particular e recusa sistematicamente soluções morais simples ou verdades absolutas.

Na tentativa da prática de uma arquitetura humana, respeitosa com a cultura do usuário, com o contexto onde ela se situa, percebe-se a incorporação, a busca e a 
preocupação com a luz do dia como elemento de composição. Em seus edifícios, a luz e o espaço envolvem o usuário, denotando a simplicidade compositiva, despojada de artifícios formais. $\mathrm{O}$ arquiteto pensa na luz como fonte de inspiração em seu processo projetual, e suas reflexões a transformam em verdadeira poesia em seus edifícios.

A tríade - sítio, homem e contexto - definem o ato projetual do arquiteto. $\mathrm{O}$ respeito ao lugar, ao contexto histórico e social e ao homem, na concepção de suas obras, transforma a arquitetura em uma celebração.

“... essa conversa da luz é muito excepcional, a luz natural então é muito excepcional, é uma conversa de fórum íntimo parece, só nossa. Se você levar para o cliente é de difícil compreensão. Parece que é uma conversa de gente louca assim, somos românticos, apaixonados". (SOARES, Apêndice digital) 


\subsection{EDIFÍCIO I:}

\section{CENTRO COMERCIAL E DE SERVIÇOS $23^{\circ} 32^{\prime} 40^{\prime \prime} S$, 46³9'46” O}

\subsubsection{Localização}

O centro comercial no bairro de Higienópolis, em São Paulo, localizado na Rua Alagoas, esquina com a Rua Tinhorão, está ao lado oposto da rua onde se situa a FAAP, Fundação Armando Álvares Penteado, em um terreno com 1.605,00m2, possuindo área construída de 1.605,00m2.

O projeto foi desenvolvido, em 1998, pelos arquitetos Luciano Margotto Soares, Marcelo Luiz Ursini e Sergio Luiz Salles, integrantes, na época, do escritório Núcleo de Arquitetura. A execução da obra ocorreu em 2001.

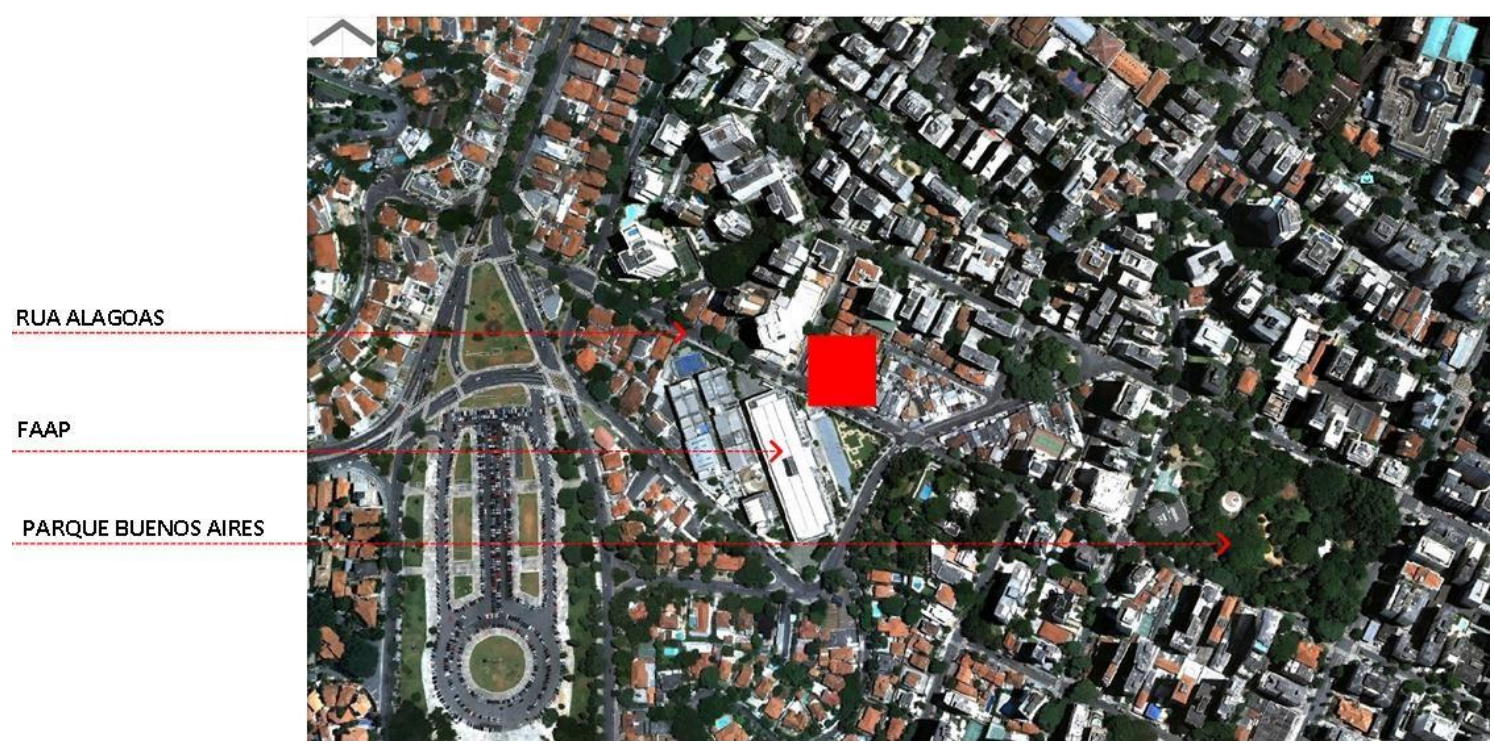

Fig.53 - Situação Centro comercial e de serviços Fonte: Google Earth

\subsubsection{Equipe Técnica}

Projeto de Arquitetura: Núcleo de Arquitetura Ltda.

Colaboradores: Ana Virgínia Italiani, Letícia Campanelli, Luis Felipe Aguiar, Paulo Lacerda de Mattos e Rita Sampaio

Estrutura Metálica: Holding Engenharia e Construções

Estrutura Concreto: Hauy \& Bechara Engenheiros Associados Ltda. 


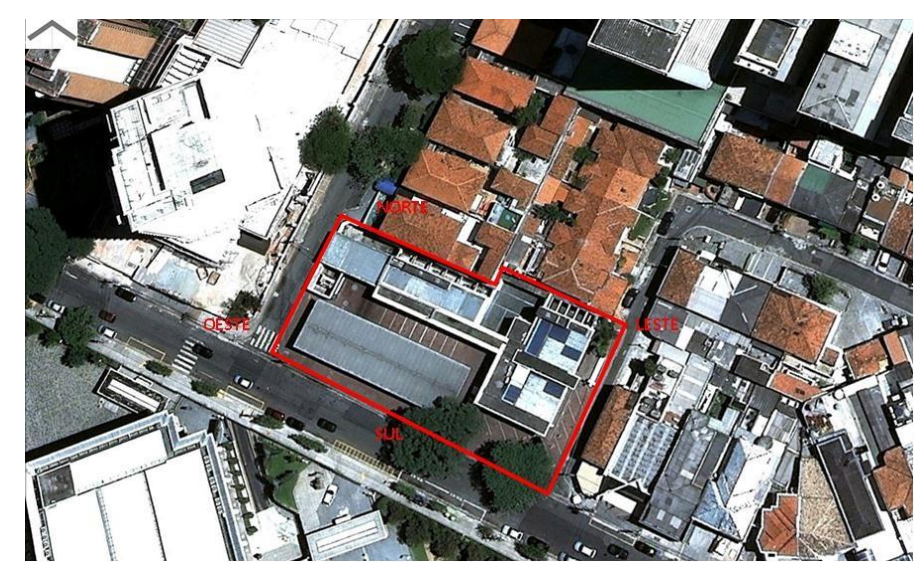

Fig.54 - Situação Centro comercial e de serviços

Fonte: Google Earth

\subsubsection{Estudo analítico do edifício: a implantação}

O centro comercial é formado por três blocos, subsolo para estacionamento e abriga ainda um posto de abastecimento de automóveis. O conjunto formado por dois dos três blocos é o que mais se destaca e está localizado na esquina, na cota mais alta do terreno. Esse conjunto, que dispõe de lojas no pavimento térreo e duas sobrelojas, é permeável ao intenso fluxo de pedestres da região, integrando o centro comercial à rua. Um vão criado entre os dois componentes, define um eixo de circulação interno e permite a passagem de pedestres entre a rua e o terceiro bloco, implantado junto à divisa do terreno.

O acesso de veículos ao subsolo está localizado entre os dois volumes principais, não comprometendo a circulação local de pedestres e não gerando conflitos de circulação.

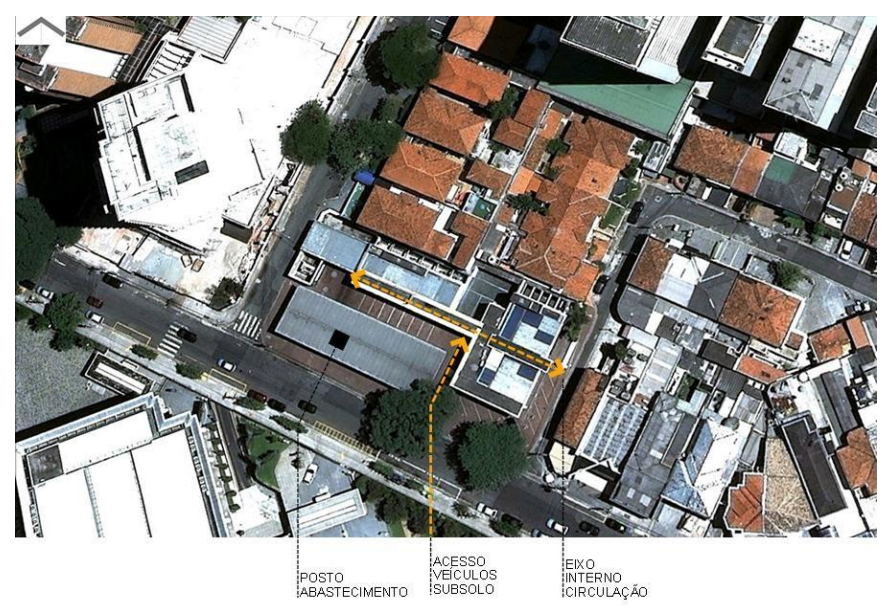

Fig.55 - Centro comercial e de serviços Fonte: Google Earth 


\subsubsection{Composição espacial}

O espaço semipúblico projetado é generoso com a cidade e com os pedestres, que lá têm prioridade, além de contar com equipamentos como bancos, sanitários públicos e marquises.

O partido adotado pelos arquitetos permitiu que fosse estabelecido um diálogo com o entorno físico imediato através da proposição de algumas relações: a escala e sequência ritmada dos pilares de apoio da laje da cobertura com as colunas do edifício da FAAP, a empena da fachada voltada para a Rua Alagoas, revestida por placas quadradas de mármore travertino, como uma citação das fachadas do edifício da FAAP, e até mesmo a cor clara adotada na pintura do conjunto.

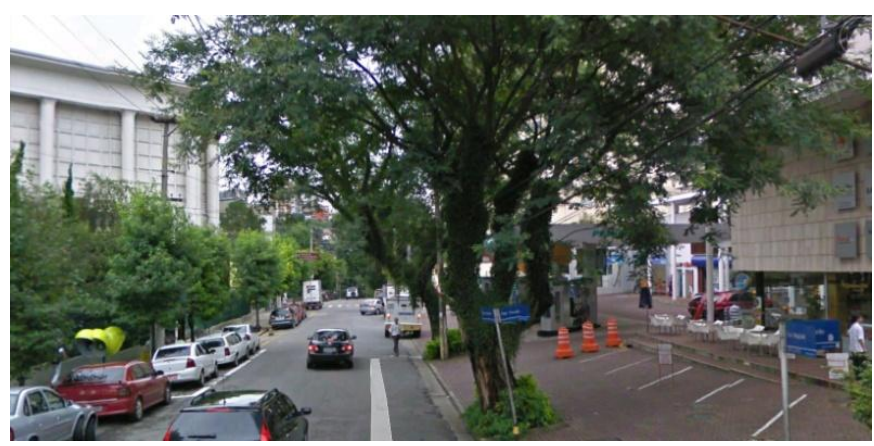

Fig.56- Centro comercial e de serviços Fonte: Google Earth

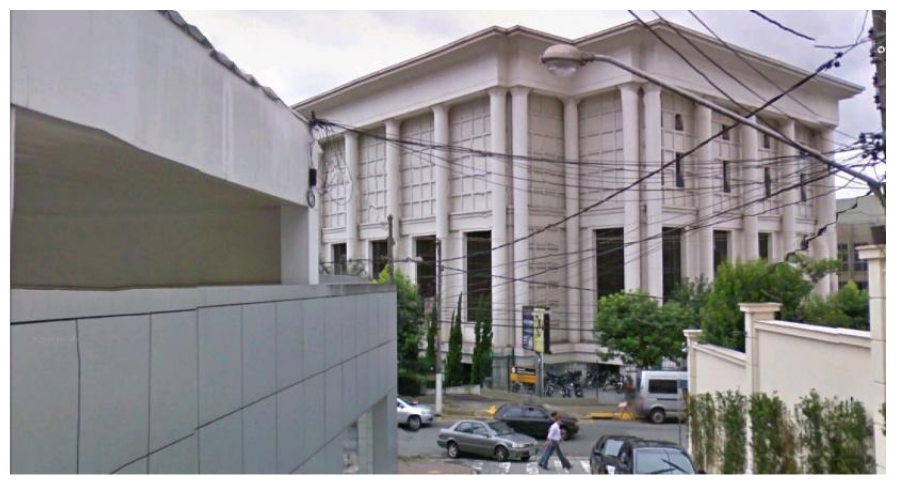

Fig.57 - FAAP - Fundação Armando Álvares Penteado Fonte: Google Earth

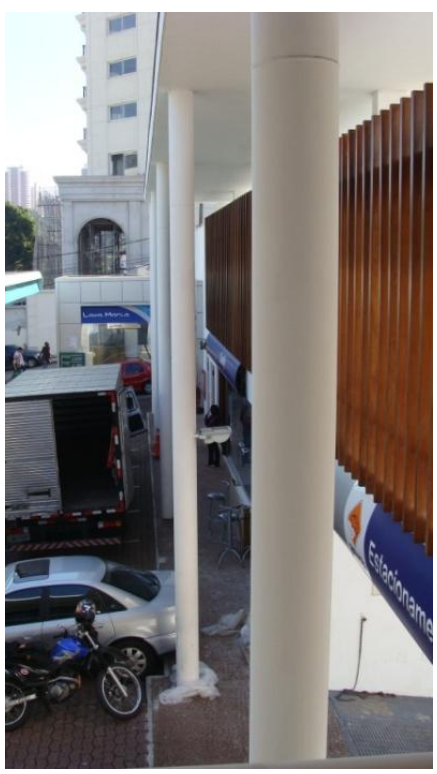

Fig.58- Centro comercial e de serviços Fonte: acervo pessoal da autora 


\subsubsection{Materiais e cores}

O sistema construtivo adotado para o edifício foi o sistema tradicional: estrutura em concreto armado e vedações em blocos de concreto. Toda a estrutura das escadas, assim como das passarelas de acesso aos escritórios, no pavimento superior, são metálicas com o piso em madeira maciça.

A passarela de acesso aos escritórios localizados no bloco dos fundos e o volume da escada possuem uma proteção externa feita com brise de madeira vertical, fixado em estrutura metálica. Nos escritórios que estão voltados para a rua lateral, o brise de madeira acontece horizontalmente.

Excetuando-se os brises de madeira aparente com acabamento em verniz, a empena voltada para a Rua Alagoas, que tem placas de mármore travertino como revestimento, e a cobertura do posto de abastecimento que adotou o projeto padrão da rede fornecedora de combustível, o restante do conjunto recebeu pintura na cor branca.

\subsubsection{Iluminação natural: aspectos funcionais e subjetivos}

A configuração do lote e a implantação dos blocos possibilitaram que todos os espaços recebessem a incidência direta da luz solar.

As aberturas das lojas no térreo, assim como dos escritórios, na sobreloja, receberam fechamento com vidro temperado translúcido.

O eixo interno de circulação, coberto com uma aba em concreto, situada acima do nível da cobertura, destaca-se, no conjunto, por romper a linearidade da platibanda. Além de exercer a função de proteção contra as intempéries, a aba de concreto, também utilizada com a mesma linguagem no Terminal da Lapa, protege a passagem interna da incidência direta do sol, criando um espaço iluminado por uma luz difusa. A verticalidade que predomina nessa rua interna é atenuada pelo rasgo de luz que ocorre entre as lajes dos blocos, permitindo que a luz seja refletida pelo grande pano da laje. 

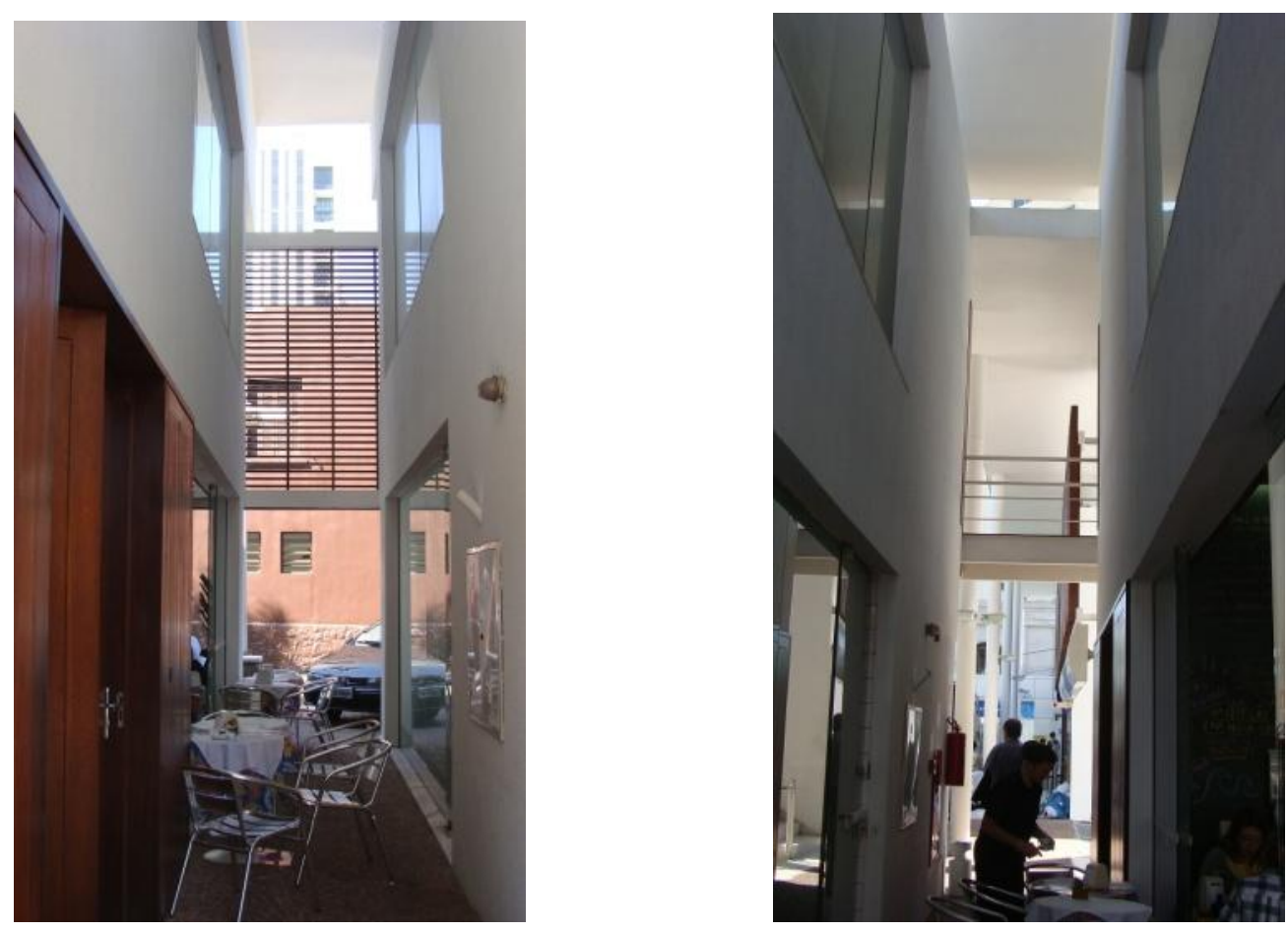

Fig.59 - Centro comercial e de serviços Fonte: acervo pessoal da autora

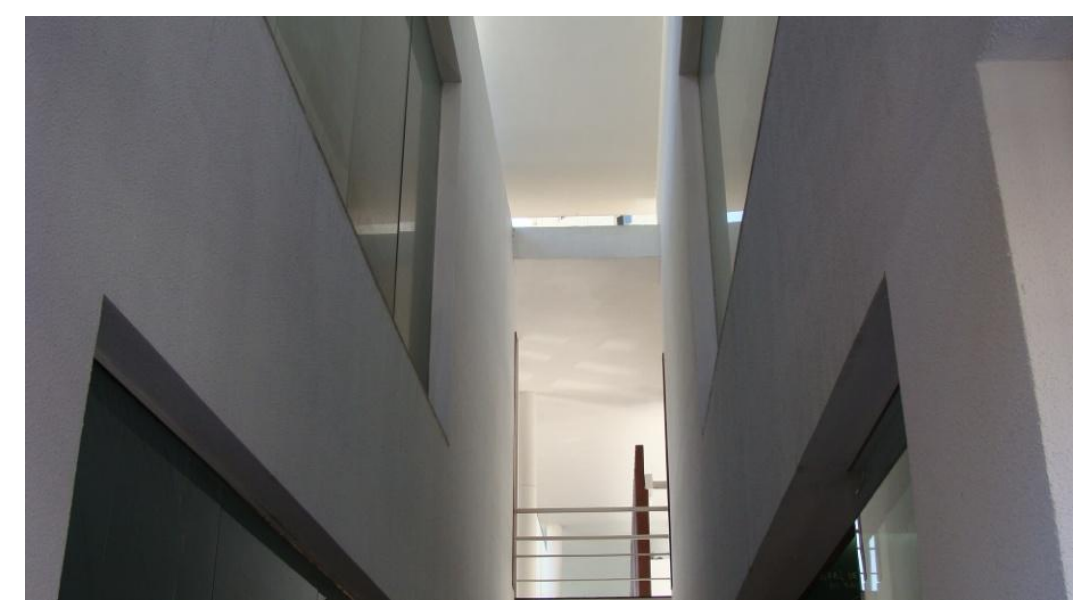

Fig.60 - Centro comercial e de serviços Fonte: acervo pessoal da autora

Apesar da orientação sul e sudeste, as fachadas voltadas para a rua e o volume da escada possuem uma proteção externa feita com brise de madeira, fixado em uma estrutura metálica, ora vertical, ora horizontal. Essa segunda pele em madeira garante aos escritórios, na sobreloja, certa privacidade, não interferindo em sua integração com o exterior e também uma proteção contra a incidência direta da luz solar, que ocorre com maior intensidade pela manhã. 


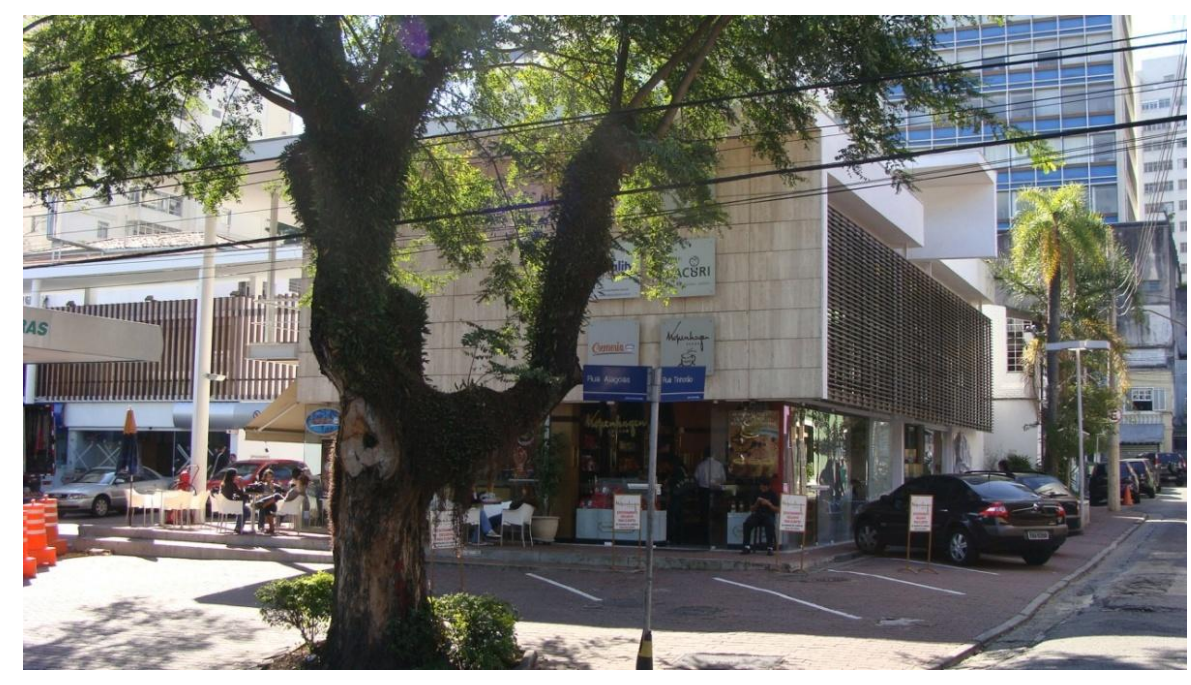

Fig.61 - Centro Comercial em Higienópolis Fonte: acervo pessoal da autora

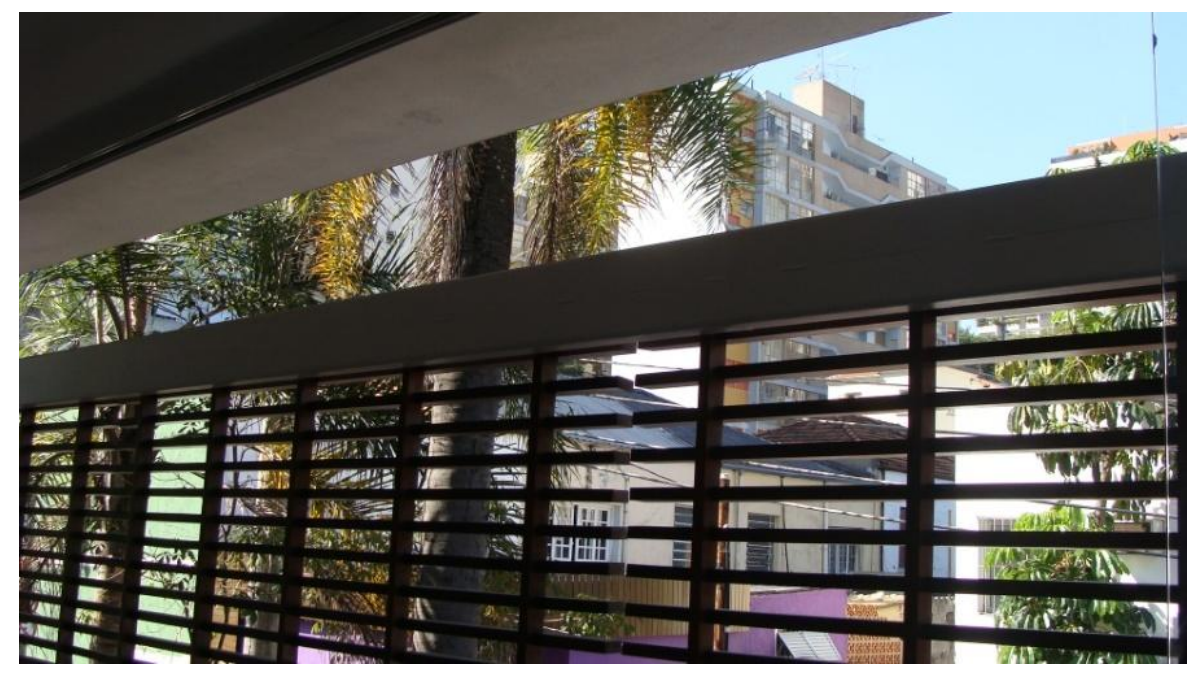

Fig.62 - Centro Comercial em Higienópolis Fonte: acervo pessoal da autora

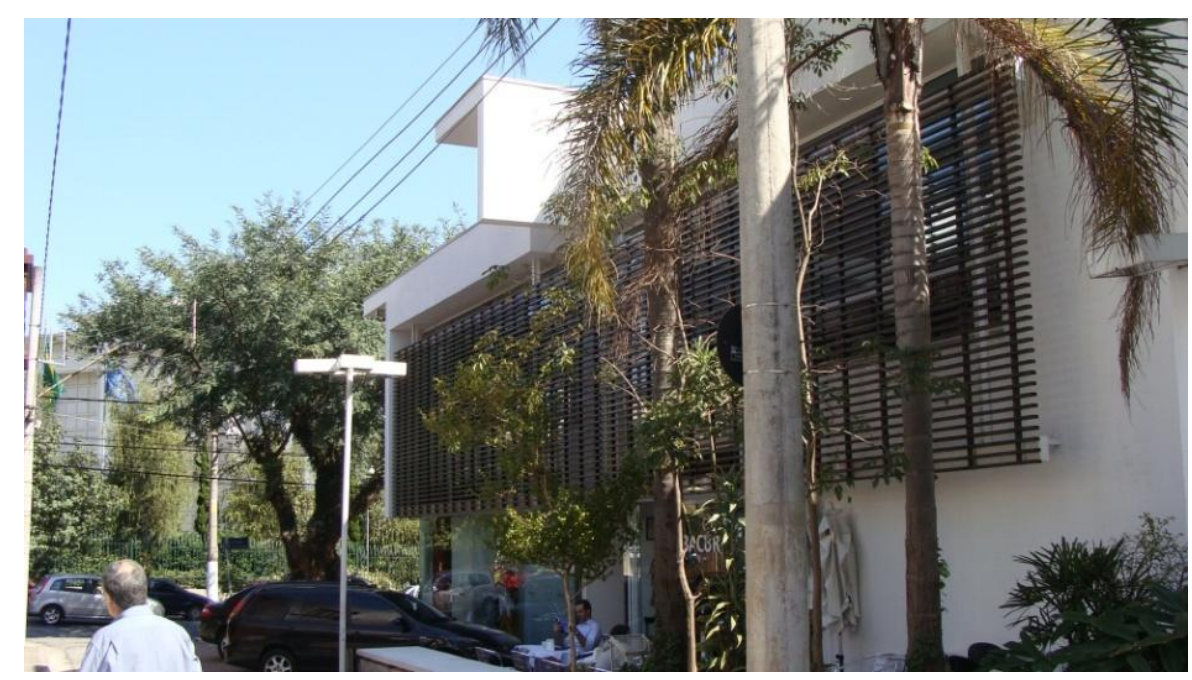

Fig.63 - Centro Comercial em Higienópolis Fonte: acervo pessoal da autora 


\subsection{EDIFÍCIO II:}

TERMINAL DE ÔNIBUS URBANO 23³1'19"S, 4641'57" O

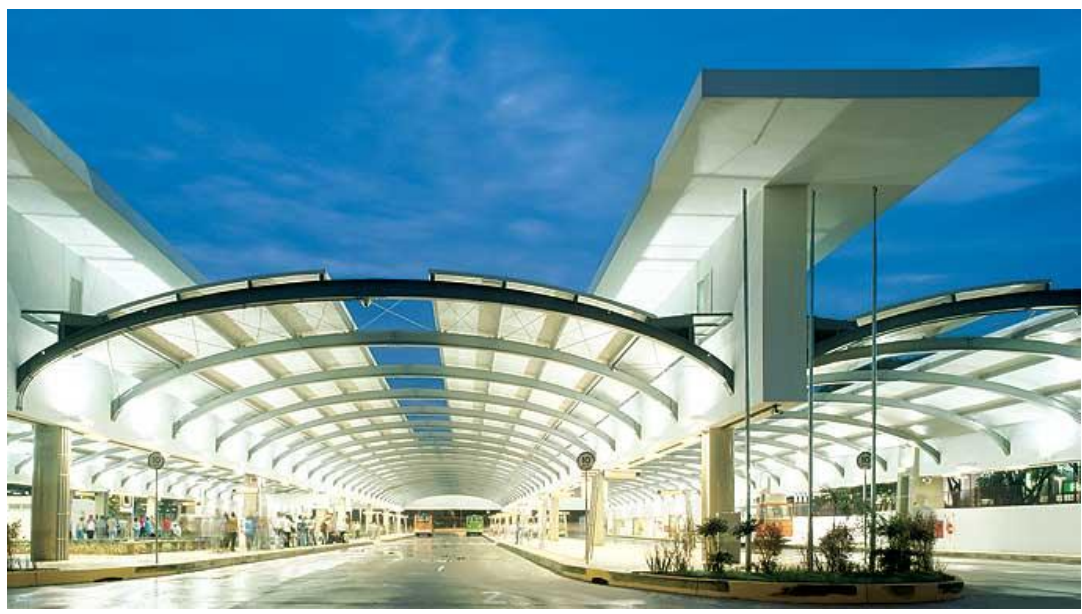

Fig.64 - Terminal da Lapa Fonte:http://www.nelsonkon.com.br/obras

\subsubsection{Localização}

O Terminal da Lapa é um terminal de ônibus da cidade de São Paulo, localizado no bairro da Lapa, na Rua Guaicurus, junto à Praça Miguel Dell'Erba, num pequeno centro comercial da região. O projeto foi desenvolvido ao longo de 2002 e a conclusão da obra foi no ano de 2003, com uma área construída de $6.597,46 \mathrm{~m}^{2}$.

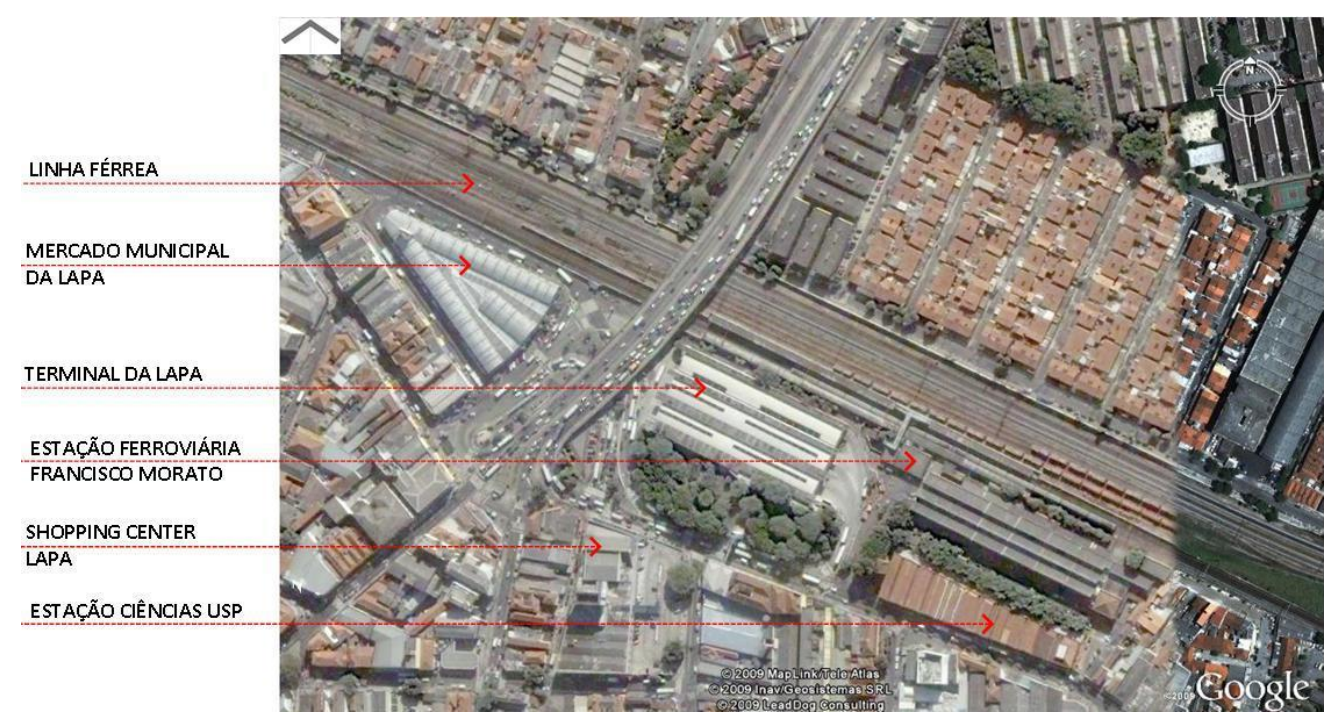

Fig.65 - Situação Terminal da Lapa Fonte: Google Earth 


\subsubsection{Equipe Técnica}

Projeto de Arquitetura: Núcleo de Arquitetura Ltda.

Colaboradores: Alexander Miyoshi, Ana Virgínia, André Ciampi, Luis Cláudio M. Dias, Letícia Campanelli, Lilian Martins, Fabio Gionco e Tieko Matsuda

Coordenação de projetos: Oficina Consultores Associados S/C Ltda.

Engenheiros: Antônio Luiz Mourão Santana e Maria Ruth Viana de Andrade

Paisagismo: Caio Machado (terminal), Luciana Maragliano (praça) e Núcleo de Arquitetura (pisos e equipamentos da praça)

Luminotécnica: Paulo Sergio Scarazzato e Irving Montanar Franco

Estrutura: Hauy \& Bechara Engenheiros Associados Ltda.

Elétrica e Hidráulica: SKK Projetos Instalações e Construções Ltda.

\subsubsection{Breve histórico}

Houve a necessidade, por parte da administração pública, de promover a adaptação de antigos terminais e a criação de outros novos, em função do aumento de tráfego e para conciliar as conexões dos vários meios de transporte.

No local onde o terminal foi implantado, havia uma praça abandonada e uma área vazia que servia como estacionamento para automóveis.

O projeto teve como prioridade os aspectos técnicos para vencer a complexidade de coordenar a frequência de 197 ônibus por hora em horários

de pico, sem, contudo, desprezar as características do entorno, bairro popular de origem operária, assumidas como fatores do projeto.

\subsubsection{Estudo analítico do edifício: a implantação e composição espacial}

O contexto dinâmico do bairro permitiu que o partido adotado estabelecesse um diálogo com o entorno físico imediato, com sua história e, sobretudo com sua vocação como foco urbano de sociabilidade popular. Estão presentes, no local, um mercado municipal, uma estação ferroviária, um shopping center, uma instituição dedicada ao ensino e à preservação 
da cultura - Estação Ciências USP, uma praça pública arborizada e a memória da antiga garagem de bondes da Lapa, edifício significativo na história dos transportes coletivos da cidade.

“... nesse projeto a gente percebeu que existem dois tipos de projetos de terminal nos debates: um é aquele que se aproxima mais da infra-estrutura, que é quase que um ponto de ônibus grande, pode-se encaixar em qualquer lugar de uma cidade, como uma infra-estrutura, com muita competência e eficiência. E o outro tipo de projeto é aquele que faz um diálogo maior com o entorno, com o contexto. E a gente achou que esse era o caso de fazer, o que nós chamamos de O Edifício. Aí lemos um texto do Rafael Moneo sobre isso. O que é um edifício? O edifício é aquela peça que tem representatividade urbana, elevação frontal, elevação nos fundos, lateral direita, lateral esquerda, de uma maneira grosseira, né? Enfim, ele tem relações íntimas com o lugar, com o contexto, que a infra-estrutura não tem. Então nós dissemos: “isso é um edifício, e não uma infra-estrutura". Porque tem um bairro que tem uma memória, e a primeira parte do contexto com o qual a gente queria se relacionar era com a memória de que aqui tinha sido um dia uma garagem de bondes da CMTC Companhia Municipal de Transportes Coletivos". (SOARES, Apêndice digital)

Devido ao desnível natural do terreno, a implantação acomodou, no nível de baixo, em cota inferior à da praça, os ambientes de atendimento aos usuários: plataformas e apoios; e, no nível de cima, os ambientes operacionais.

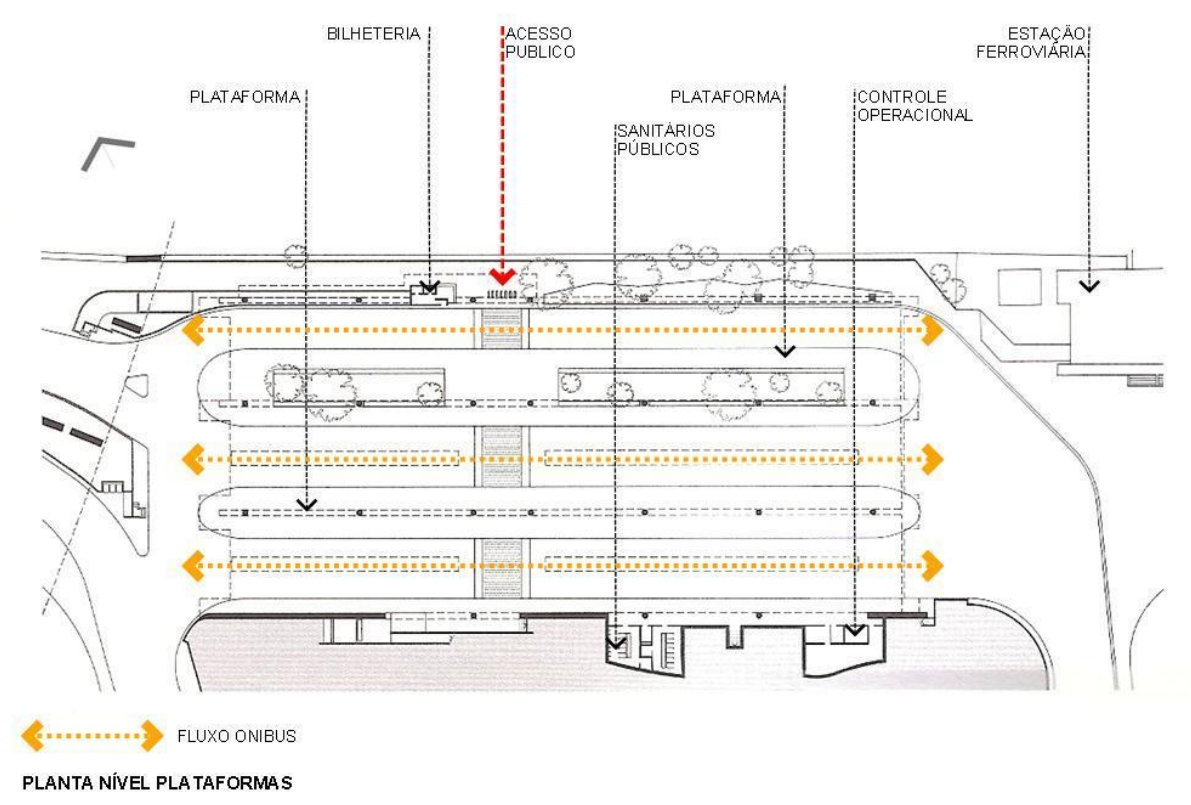

Fig.66 - Planta Terminal da Lapa Fonte: www.arcoweb.com.br 


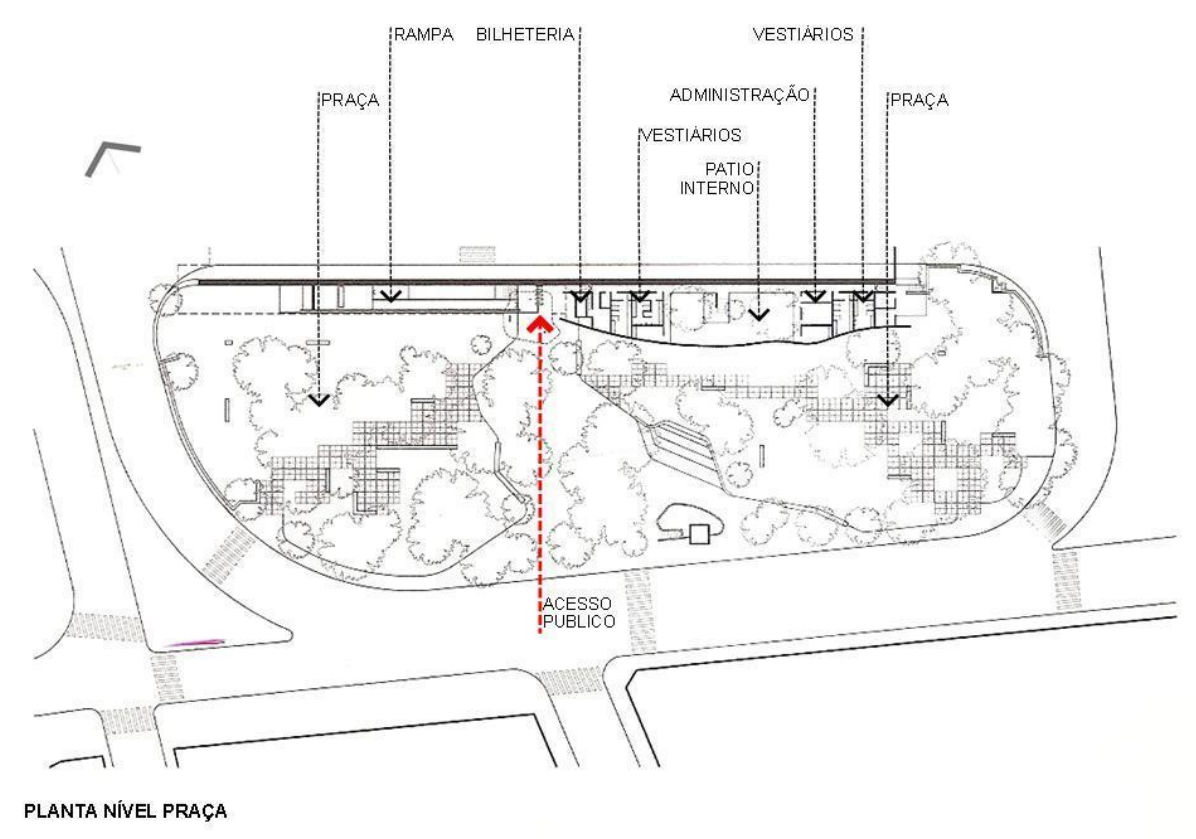

Fig.67 - Planta Terminal da Lapa Fonte: www.arcoweb.com.br

Com a configuração do edifício, a Praça Miguel Dell' Erba ganhou uma área verde maior, com dois novos planos de arborização: um dentro do próprio projeto, em um pátio interno, ao longo da plataforma mais larga; e outro compondo uma alameda paralela ao muro de divisa da ferrovia.

Dois acessos permitiram que os fluxos de pedestres fossem reorganizados: um na alameda dos fundos, junto à ferrovia, no caminho que une a estação ao mercado, e outro junto à praça.

A parede de curva sinuosa delimita a praça externa e a área administrativa. Ela preserva e ao mesmo tempo tira partido das árvores existentes, criando pátios internos e dialogando com os edifícios de tijolos do entorno. 


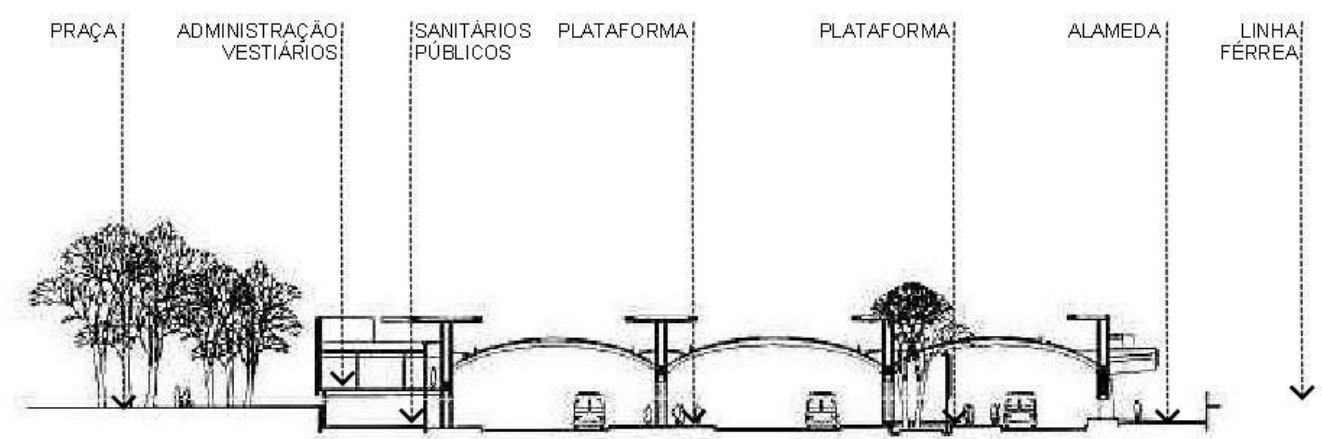

CORTE ESQUEMÁ TICO

Fig.68- Corte esquemático Terminal da Lapa Fonte: www.arcoweb.com.br

\subsubsection{Materiais e cores}

A estrutura do terminal é composta por pilares e vigas em concreto e os painéis de vedação em alvenaria de tijolos. A cobertura em telhas metálicas está apoiada sobre vigas metálicas em arco, na cor grafite. O branco é a cor predominante em todo o edifício.

O vidro foi o material escolhido pelo arquiteto para fazer o fechamento entre a cobertura metálica e a viga longitudinal de concreto. As abas sobre a cobertura são em concreto e receberam pintura na cor branca.

O tijolo aparente como revestimento acontece em três momentos do edifício, estabelecendo uma relação imediata com o entorno: na parede curva que delimita o espaço do terminal junto à praça, na parede que delimita o espaço do terminal junto à alameda e na empena da fachada leste. Três marquises em concreto, na parte superior da empena, foram executadas nessa fachada. Tal gesto sinaliza externamente a exata localização das plataformas de embarque. 

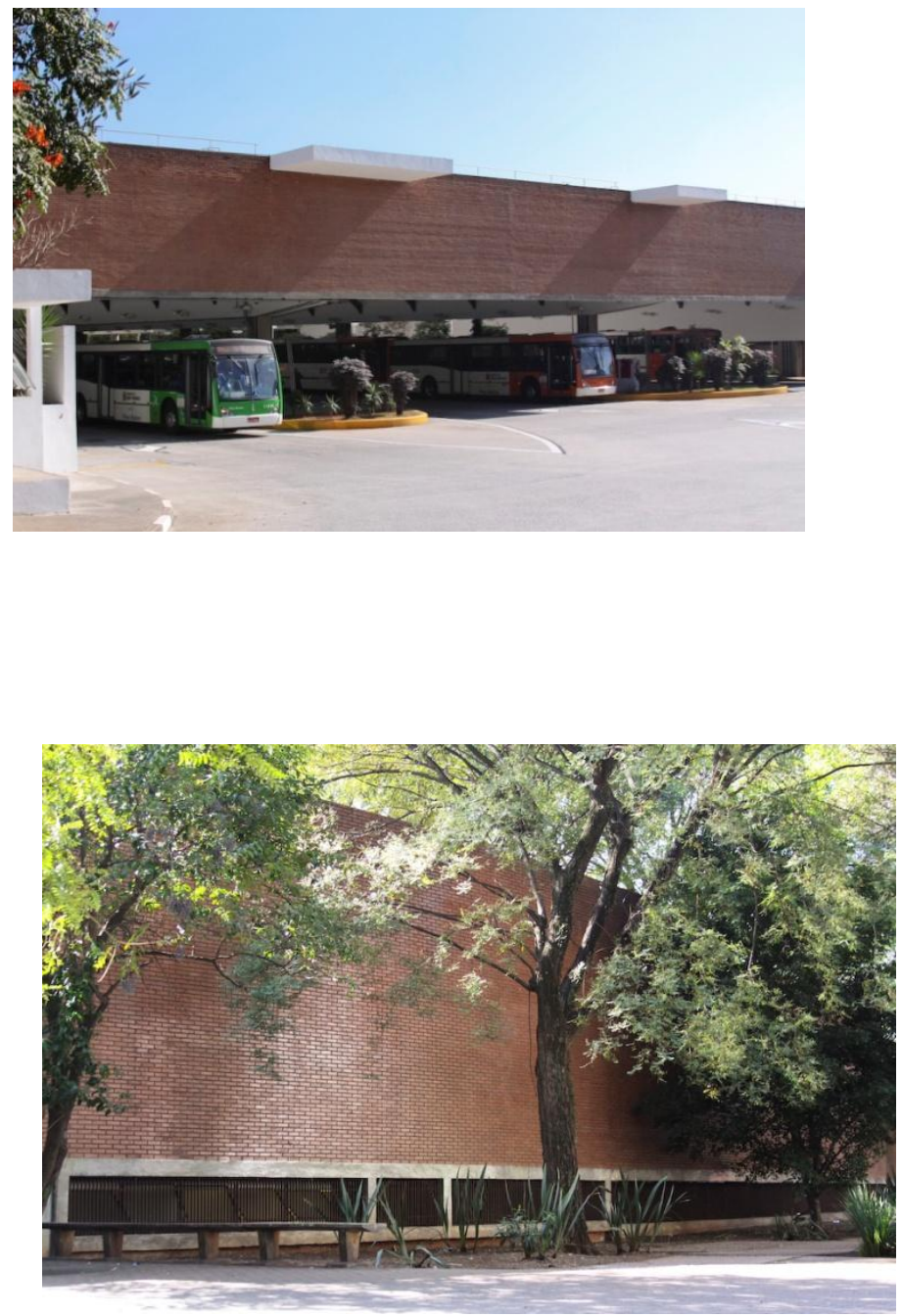

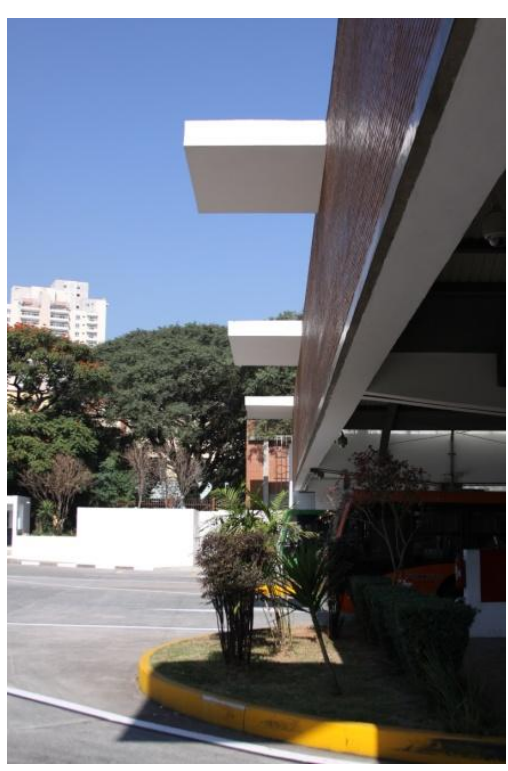

Fig.69 - Terminal da Lapa Fonte: acervo pessoal da autora

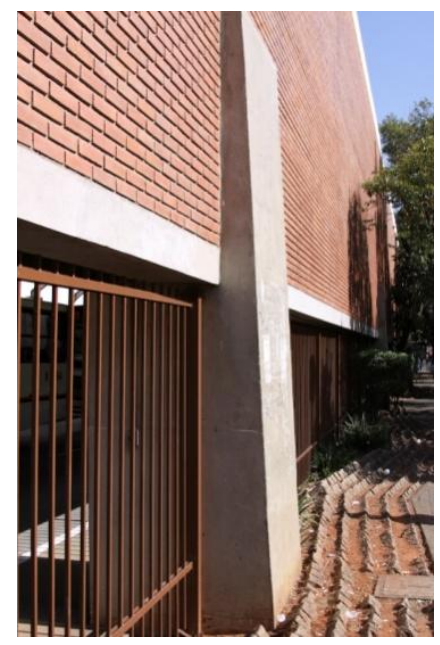

Fig.70 - Terminal da Lapa Fonte: acervo pessoal da autora 


\subsubsection{Iluminação natural: aspectos funcionais e subjetivos}

A solução formal adotada, um grande paralelogramo aberto em suas extremidades, permitiu o desenho com a luz do dia dentro do terminal e a saída dos gases emitidos pelos ônibus.
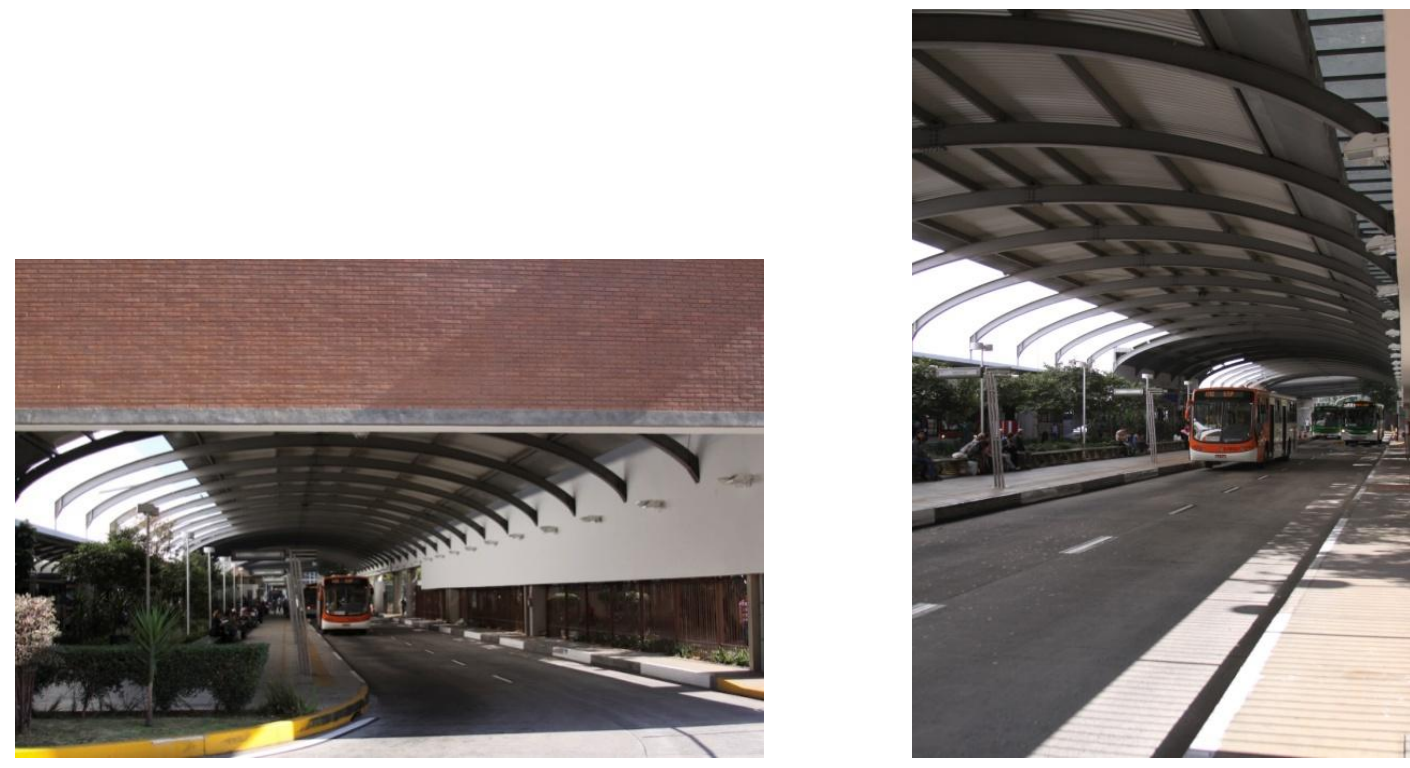

Fig.71 - Terminal da Lapa Fonte: acervo pessoal da autora

Para proteger as plataformas das intempéries e assegurar a incidência de luz, de forma indireta e difusa, foi proposta a cobertura em arco, que não toca as vigas longitudinais de concreto, fazendo surgir a abertura com vedação em vidro ao longo dos cento e dez metros de extensão do terminal.

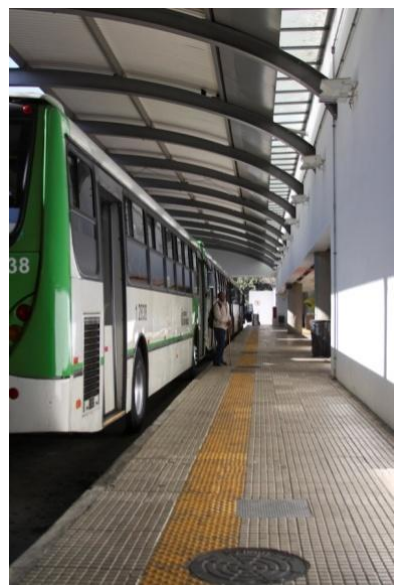

Fig.72 - Terminal da Lapa Fonte: acervo pessoal da autora 
No encontro entre as vigas longitudinais e a estrutura metálica foram criadas abas horizontais que têm a função de corrigir a incidência do sol e, consequentemente, do calor excessivo, protegendo assim o usuário durante o seu período de permanência no local.

Na parte central dos arcos, acontece uma interrupção linear da cobertura metálica a fim de permitir, não apenas a exaustão de gases como também a entrada da luz do dia sobre as áreas de circulação dos ônibus.
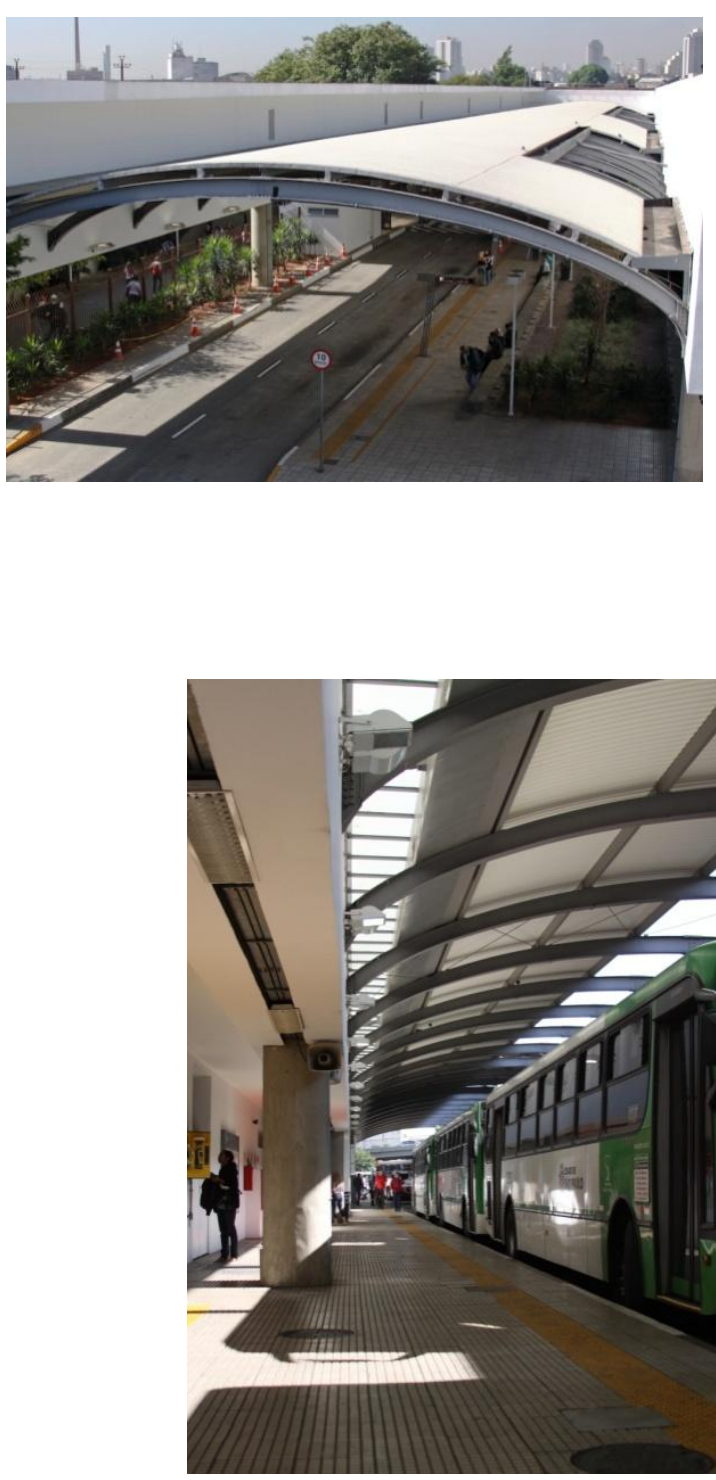

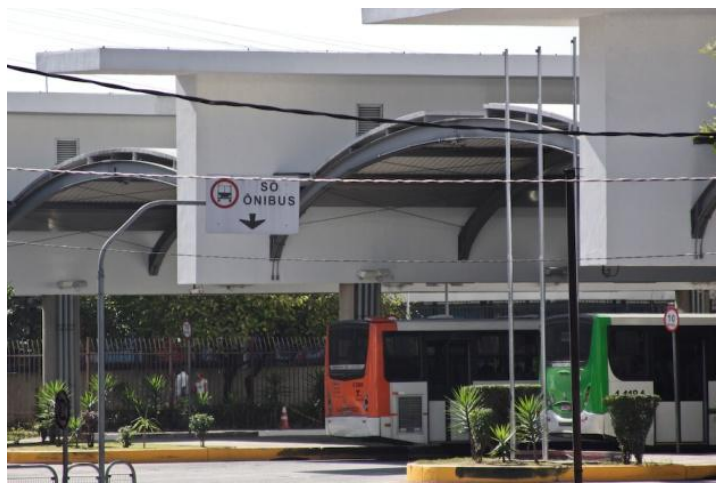

Fig.73 - Terminal da Lapa Fonte: acervo pessoal da autora

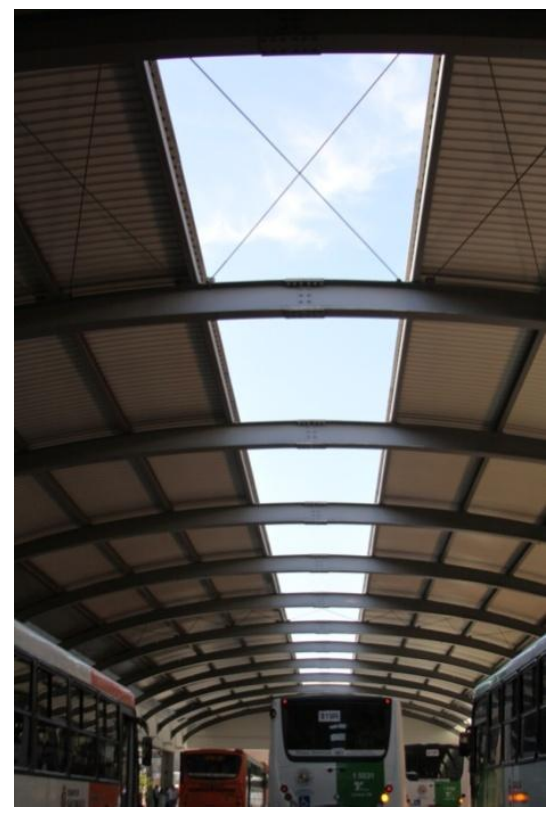

Fig.74 - Terminal da Lapa Fonte: acervo pessoal da autora

A ênfase do edifício está na trajetória da luz do dia em seu interior. Luz e matéria, luz e espaço são fatores dialéticos de uma constante troca no edifício. 
"Arquitetura é escultura habitada".

Constantin Brancusi

CAPÍTULO IV

A VISÃO DA LUZ DO DIA PARA OS ARQUITETOS DO ESCRITÓRIO PAULISTANO

ANDRADE MORETTIN

O escritório Andrade Morettin é composto pelos arquitetos Marcelo Henneberg Morettin e Vinicius Hernandes de Andrade, ambos formados pela FAUUSP, o primeiro em 1991 e o segundo em 1992, respectivamente. A dupla, com escritório estabelecido desde 1997, assina importantes projetos tanto no Brasil como no exterior, além da conquista de premiações nacionais e internacionais. Os arquitetos tiveram diferentes experiências de trabalho: Vinícius Andrade trabalhou nos escritórios de Eduardo de Almeida, VIA Arquitetura e no escritório do arquiteto espanhol J. Emili Donato, enquanto Marcelo Morettin trabalhou nos escritórios de Joaquim Guedes e Marcelo Fragelli. O escritório atua na área de projetos de arquitetura e urbanismo e trabalha com projetos de diversas escalas e de natureza bastante variadas, tanto para o setor público quanto para o setor privado. Além da atuação profissional, ambos exercem a atividade acadêmica como professores na Escola da Cidade.

A arquitetura realizada pelos profissionais provém da sua formação acadêmica na FAUUSP, pois além das atividades curriculares, eles estagiaram nos escritórios particulares de professores da instituição, onde ocorreu a reafirmação dos preceitos apreendidos na escola.

Apesar da influência exercida pela FAUUSP em sua formação, Vinicius Andrade acredita que os arquitetos da sua geração não elaboram o projeto arquitetônico por síntese, o que se distingue da arquitetura praticada na FAUUSP, que, segundo ele, é uma arquitetura de partido.

“O projeto que tem partido, portanto, tem a síntese. A síntese é aquele momento em que todas as informações principais do projeto se fundem e desse cruzamento sai uma solução única que resolve todos os problemas a uma só vez. Então, nessa hora, as disciplinas todas são tratadas com alguma superficialidade, porque senão não se consegue operar essa síntese. Eu acho que vem da própria forma de projetar 
esse modus operandi. Eu realmente não penso que seja uma coisa de hierarquia de importância, mas sim o momento em que é pertinente a participação de cada especialidade". (ANDRADE, Apêndice digital)

A valorização da multidisciplinaridade é uma postura defendida pelo escritório durante o processo de projeto. Vinicius Andrade afirma que ao se praticar uma arquitetura mais coletiva e mais técnica, ela se torna menos autoral. Para ilustrar o seu argumento, ele traça um paralelo entre o arquiteto da Escola Paulista e o diretor de cinema da Escola Moderna de Cinema, o Cinema Novo, onde a centralização de todas as decisões por parte de um profissional tem como resultado uma expressão autoral.

\footnotetext{
“E não há de ser por acaso que a concepção moderna de autoria, em sua expressão mais individualista, ceda lugar aqui à valorização de trabalhos em equipes, nos quais a ênfase por vezes parece recair menos sobre o objeto arquitetônico em si do que sobre o processo da arquitetura como um todo, da concepção à execução". (MILHEIRO, 2006, p.21)
}

A formação na FAUUSP foi decisiva para a carreira dos arquitetos. Segundo depoimento de Vinicius Andrade, o seu aprendizado da arquitetura teve início pelo próprio edifício da FAUUSP, que ele considera ser uma escola dentro da própria escola de arquitetura. A sua visão sobre a arquitetura decorre das lições apreendidas a partir de densos conteúdos acadêmicos. Apesar de toda essa influência na formação dos arquitetos, a arquitetura praticada por eles distancia-se do brutalismo, sem jamais deixar de ser a arquitetura da escola paulista.

\footnotetext{
"Que o elemento catalisador, aqui, seja a faculdade, apenas vem confirmar o quanto a formulação de um programa pedagógico forte continua sendo crucial para conduzir a uma prática conseqüente, seja onde for"..$^{9}$ (MILHEIRO, 2006, p.18)
}

A natureza dos projetos dos arquitetos prioriza o processo construtivo do edifício e procura incorporar, cada vez mais, a cada projeto, componentes industrializados que

\footnotetext{
${ }^{9}$ A partir do texto Prática em comum, assinado por Ana Luiza Nobre, doutora em história e professora de história da arte e da arquitetura na PUC - Rio.
} 
resultam em rapidez, economia e um rigor construtivo na obra. A definição dos materiais depende do conceito do projeto.

Já durante a formação acadêmica dos arquitetos, a reflexão sobre a utilização da luz do dia se fazia presente. Os conteúdos teóricos expositivos da disciplina de Iluminação Natural despertaram o interesse deles pelo comportamento da luz nos edifícios e deu sustentação à prática de uma arquitetura comprometida com os aspectos naturais que envolvem o edifício.

\footnotetext{
"Nós somos arquitetos que temos paixão pela tua disciplina". (ANDRADE, Apêndice digital)
}

Independente da escala ou da complexidade do projeto, o processo projetual dos arquitetos se desenvolve a partir de uma interpretação inicial do problema, seguido de pesquisas e observações de casos análogos para que se chegue a um conceito de projeto. $\mathrm{O}$ partido arquitetônico é definido após a compreensão desse conceito e, a partir disso, as diretrizes de projeto são estabelecidas. Nessa fase do processo, os arquitetos consideram fundamental a consulta aos profissionais especialistas em cada área.

Ambos acreditam que a luz do dia desempenha um papel fundamental na arquitetura, definindo, inclusive, a qualidade dos espaços. O seu grau de importância varia de acordo com o uso do edifício. Para determinados usos, a luz do dia é desejável enquanto que para outros usos específicos, ela torna-se totalmente indesejável, como no caso de cinemas, laboratórios de revelações químicas, etc.

Vinicius Andrade não considera que a luz do dia seja isoladamente a protagonista de um projeto. Dependendo da natureza do projeto, alguns elementos se sobressaem e têm maior relevância que outros. A luz do dia está diretamente vinculada com a relação espaço interno/externo e com a implantação do edifício; assim como a definição dos materiais depende das suas respostas satisfatórias ao conceito do projeto.

O espaço externo é o responsável por agregar uma série de benefícios e condições ao espaço construído: a luz do dia, a chuva, o vento, a temperatura, a percepção espacial e a visão. A luz do dia faz parte da percepção do espaço, e, desta forma, é a característica mais perceptível da relação interno/externo. 


\begin{abstract}
"A gente começa pensando justamente no desempenho do edifício, na relação do espaço interno/externo. Então nesse sentido, a luz vem a priori. Se a gente considerar que a luz vem carregada junto com esse pensamento do objeto e da relação interno/externo, a primeiríssima coisa é a relação do edifício com a luz". (ANDRADE, Apêndice digital)
\end{abstract}

Por acreditar que os edifícios devam desempenhar as suas funções durante os trezentos e sessenta e cinco dias do ano, os arquitetos entendem a luz do dia como um importante elemento enquanto desempenho. Nos projetos do escritório, a luz do dia é pensada com um elemento que tem um papel a ser exercido no espaço construído; e ela deve, portanto, cumprir as obrigações para as quais foi projetada. A luz é desenhada do ponto de vista do seu desempenho técnico e também é a responsável pela qualidade do ambiente construído. É recorrente, na obra dos arquitetos, a ênfase dada ao contraste entre transparências e opacidades. O pensar na luz do dia não acontece de maneira intuitiva nos projetos dos profissionais; todas as decisões tomadas com relação à iluminação natural em um projeto são previamente analisadas, testadas e experimentadas antes de se concretizarem no objeto construído.

Para a observação do comportamento da luz do dia nos espaços projetados, os arquitetos se servem de algumas ferramentas: inicialmente a visualização mental espacial, os modelos em escala reduzida e, posteriormente, o uso de softwares que permitem a verificação do desempenho da luz e das sombras.

O trabalho do arquiteto Rino Levi se apresenta como uma referência permanente para os arquitetos. A arquitetura praticada pelo escritório, segundo o arquiteto Vinícius, é uma releitura do legado de Rino Levi e, essa influência se formou a partir dos conteúdos da FAUUSP, em particular da disciplina de lluminação Natural. 


\subsection{EDIFÍCIO I}

ESCOLA ESTADUAL - COORDENADAS 22 ${ }^{\circ} 51^{\prime} 49^{\prime \prime} S, 47^{\circ} 08^{\prime} 34^{\prime \prime} O$

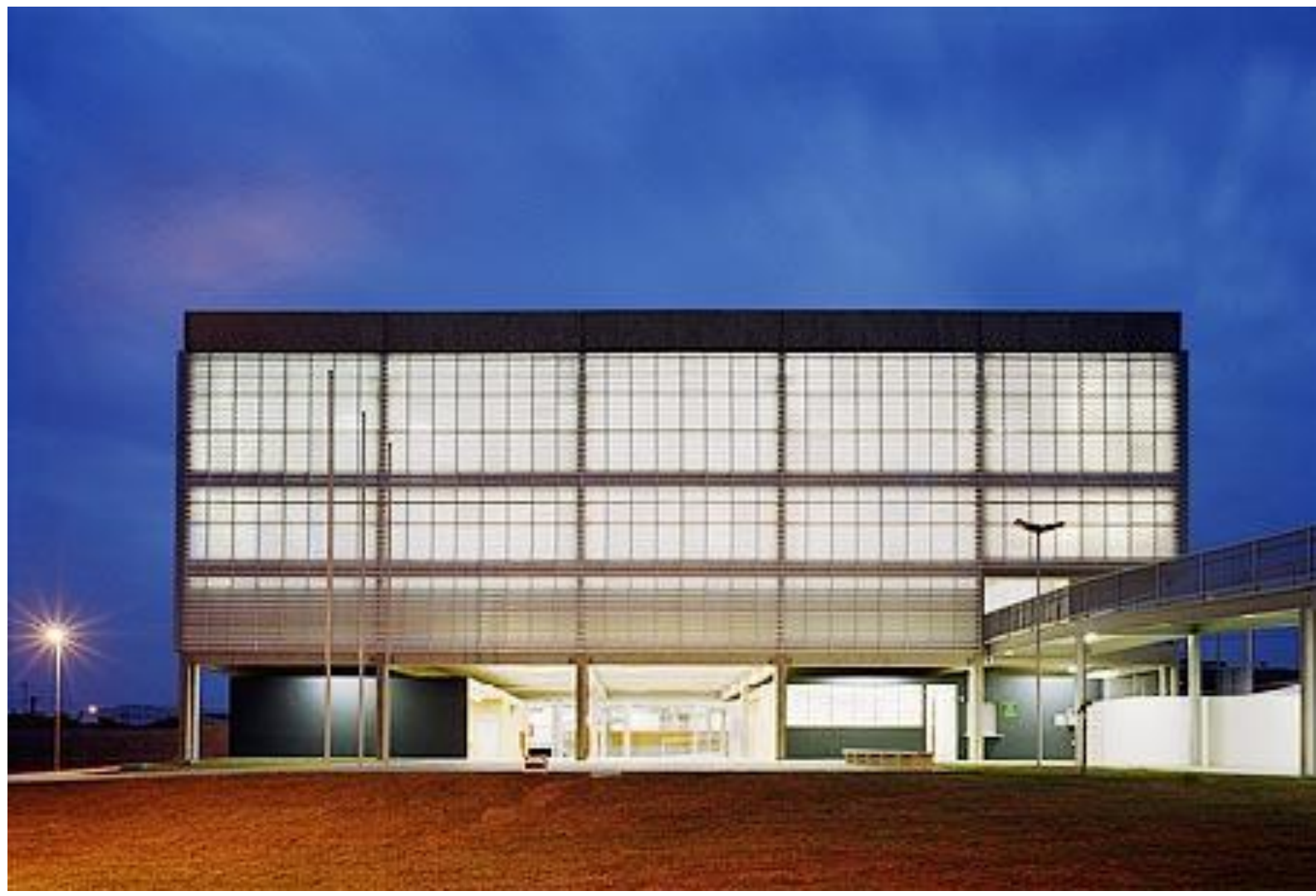

Fig.75 - Escola Estadual Jorn. Roberto Marinho Fonte: http://www2.nelsonkon.com.br

\subsubsection{Localização}

A Escola Estadual Jornalista Roberto Marinho está localizada a noroeste da cidade de Campinas, São Paulo, em uma área residencial de baixa renda, na Vila Renascença. Possui uma área construída de $1.870,00 \mathrm{~m} 2$ em um terreno com área de $3.660,00 \mathrm{~m} 2$. o projeto arquitetônico foi realizado em 2003, e a obra foi concluída no ano de 2004. 


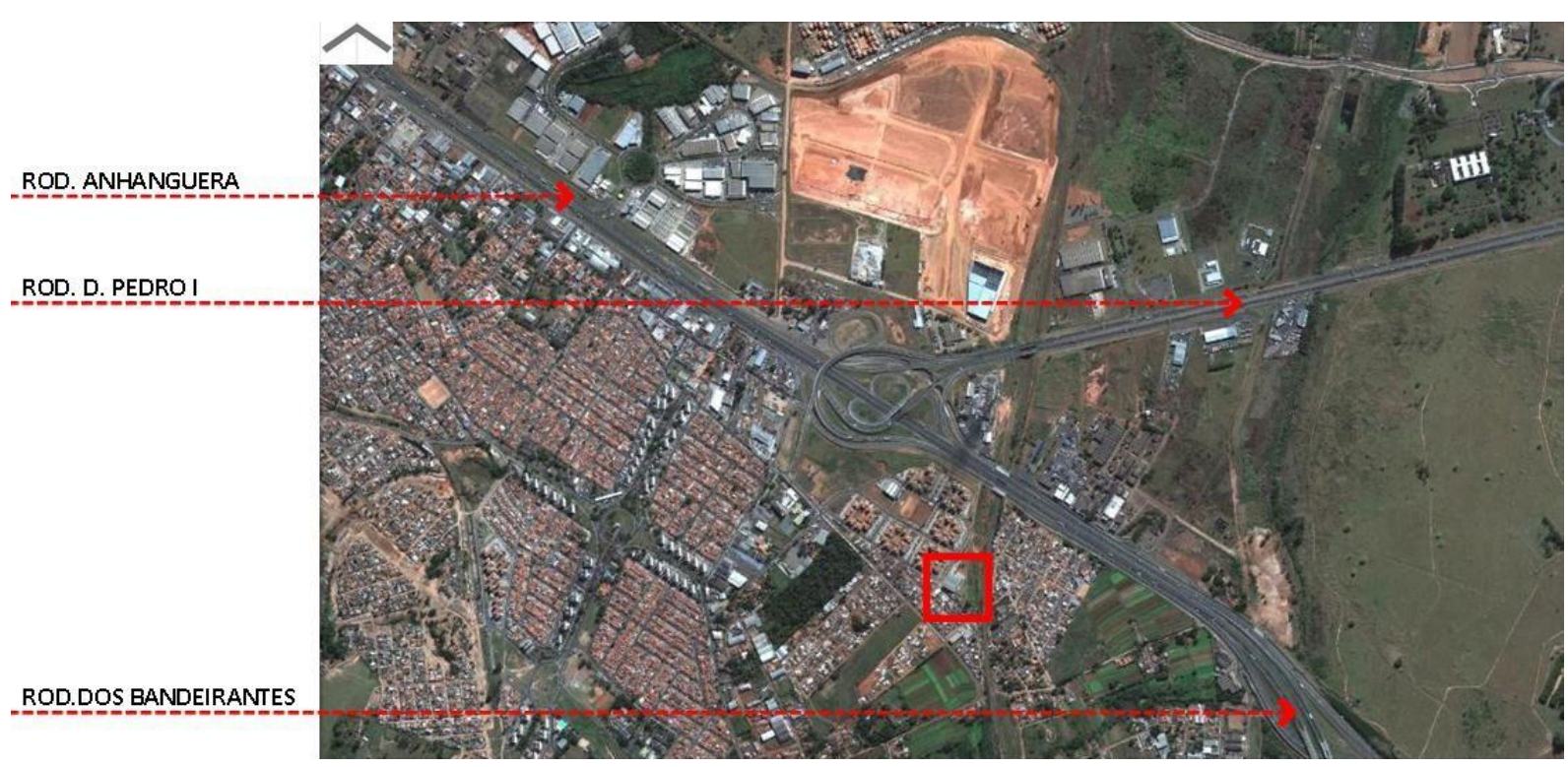

Fig.76 - Situação Escola Estadual Jorn. Roberto Marinho Fonte: Google Earth

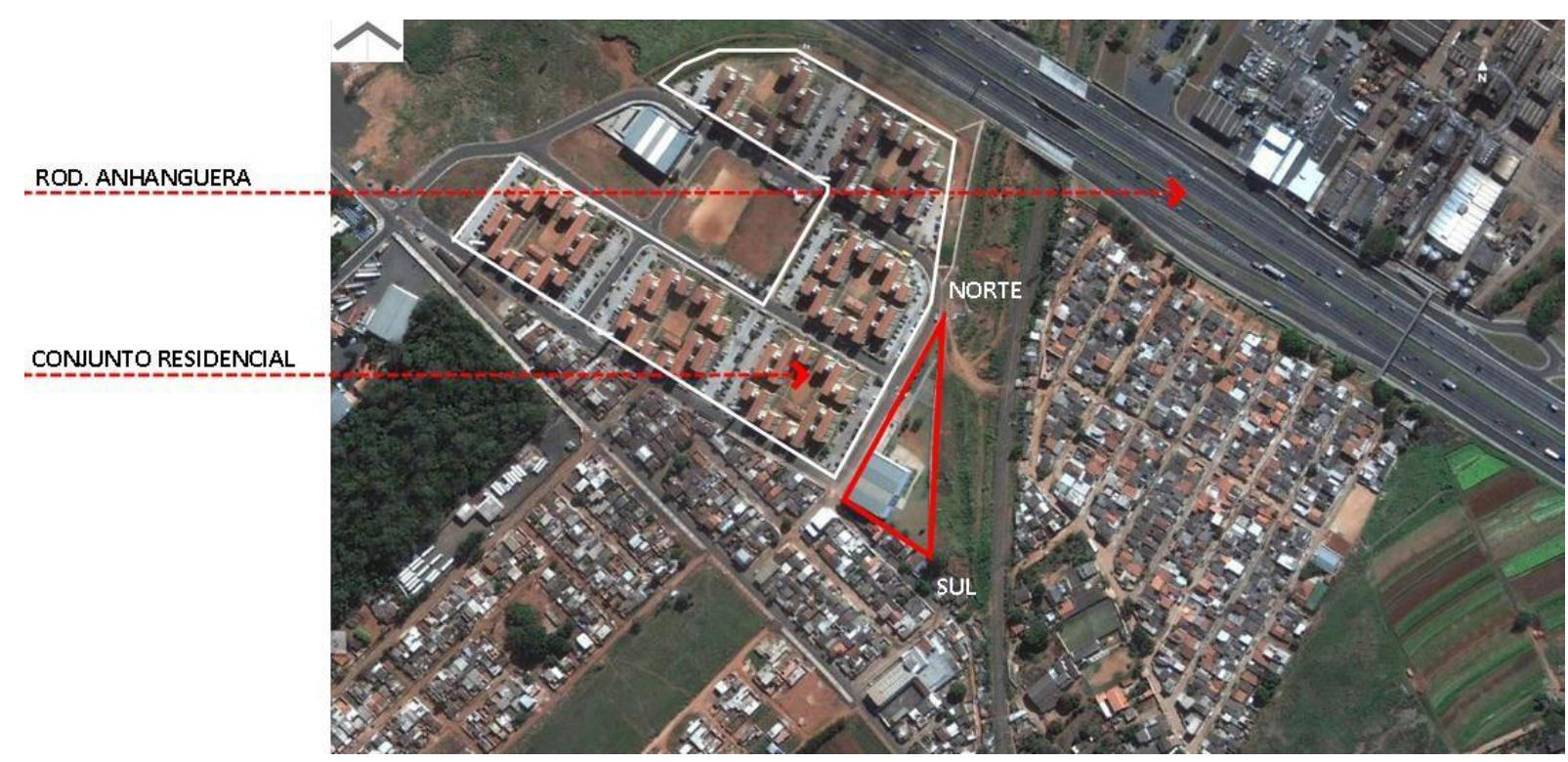

Fig.77 - Situação Escola Estadual Jorn. Roberto Marinho Fonte: Google Earth

\subsubsection{Equipe Técnica}

Projeto de Arquitetura: Vinícius Andrade e Marcelo Morettin

Colaboradores: Thiago Natal Duarte, Renata Azevedo e Marina Mermelstein

Estrutura de Concreto: Ruy Bentes, Ibsem Puleo Uvo e CTC Projetos e Consultorias

Estrutura Metálica: Kurkdjian Fruchtengarten Engenheiros Associados e Haddad \& Cunha Engenharia de Projeto 
Instalações Hidráulicas: Marcos Quinteiro

Instalações Elétricas: Ulisses Pereira Rosa Borges

\subsubsection{Breve histórico}

A FDE - Fundação para o Desenvolvimento da Educação é responsável por viabilizar a execução das políticas educacionais definidas pela Secretaria da Educação do Estado de São Paulo, implantando e gerindo programas, projetos e ações destinadas a garantir o bom funcionamento, o crescimento e o aprimoramento da rede pública estadual de ensino.

A fim de atender às necessidades de algumas comunidades locais e com o intuito de testar um novo padrão para as escolas públicas estaduais, a FDE convidou alguns escritórios de arquitetura da cidade de São Paulo para elaborar o projeto de arquitetura para algumas unidades específicas, a partir da utilização de estruturas pré-fabricadas em concreto. Entre os selecionados está o escritório Andrade Moretti, que desenvolveu o projeto para a Escola Estadual Jornalista Roberto Marinho.

\subsubsection{Estudo analítico do edifício: a implantação}

As metas de projeto definidas pelos profissionais era a de que a escola, além de abrigar em um único espaço as diferentes atividades previstas pelo programa, deveria estabelecer uma relação com o entorno, destacar-se na paisagem local e também agir como um elemento integrador da comunidade.

A partir dessas premissas, os arquitetos propuseram um grande paralelogramo selado com dimensões de $36,00 \mathrm{~m}$ por $43,20 \mathrm{~m}$, com térreo e mais três pavimentos, implantado em uma das extremidades do terreno triangular e de topografia plana. Devido a esta configuração, as faces do edifício estão orientadas para nordeste, noroeste, sudeste e sudoeste.

O acesso de pedestres à edificação ocorre em dois níveis: ao nível do térreo, com acesso direto pela rua e através de uma rampa longitudinal ao terreno que conduz à quadra poliesportiva localizada no primeiro pavimento. $\mathrm{O}$ acesso de veículos acontece junto à torre que abriga a caixa d'água e também serve como um referencial na paisagem. 


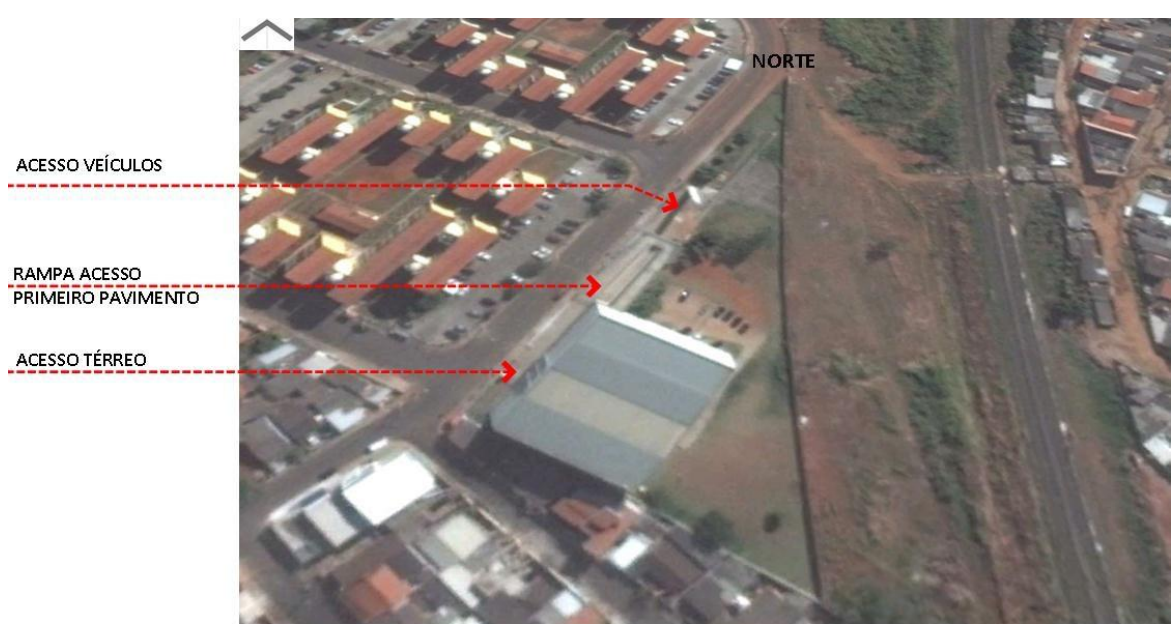

Fig.78 - Implantação Escola Estadual Jorn. Roberto Marinho Fonte: Google Earth

4.1.5. Composição espacial

Dois eixos principais definem os espaços do edifício. Um eixo perpendicular à via de acesso no térreo define um átrio, com pé direito que ocupa toda a altura do edifício, distribuindo os fluxos internamente. Um segundo eixo, perpendicular ao primeiro, estabelece a conexão entre a rua interna, o pátio interno e o pátio descoberto.

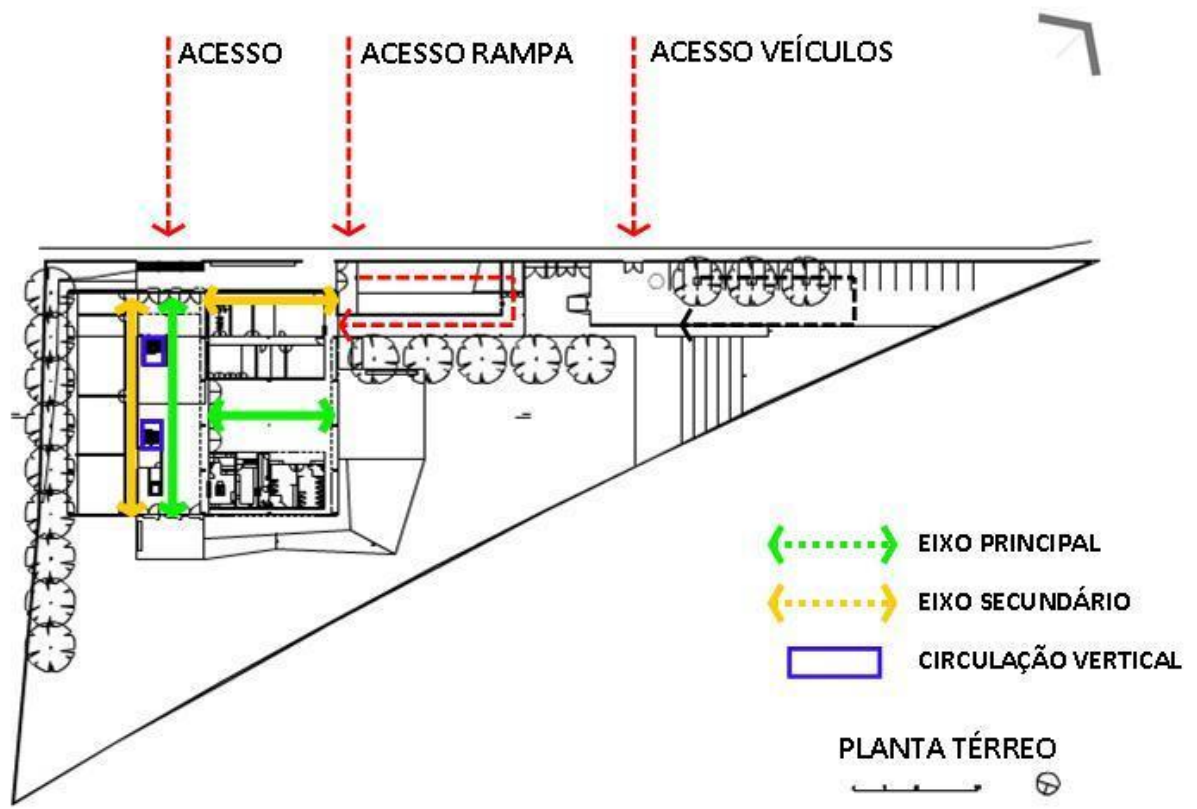

Fig.79 - Planta térreo Escola Estadual Jorn. Roberto Marinho Fonte: http://www.andrademorettin.com.br 
O átrio, que funciona como uma rua interna, divide o edifício em dois blocos, promovendo a integração entre o térreo e os demais pavimentos, além de concentrar toda a circulação vertical - escadas e elevador. O térreo concentra as áreas administrativas, de serviços, vivência em um bloco e, no outro, a área pedagógica. Incorporada ao edifício, no primeiro pavimento, está localizada a quadra poliesportiva e separado pelo grande vazio, o bloco que abriga as quinze salas de aula.

A rampa marca a volumetria externa e permite o acesso exclusivo dos moradores da comunidade à quadra poliesportiva durante os finais de semana. A quadra, no pavimento superior, com pé direito triplo, está posicionada sobre as áreas administrativa e de serviços.

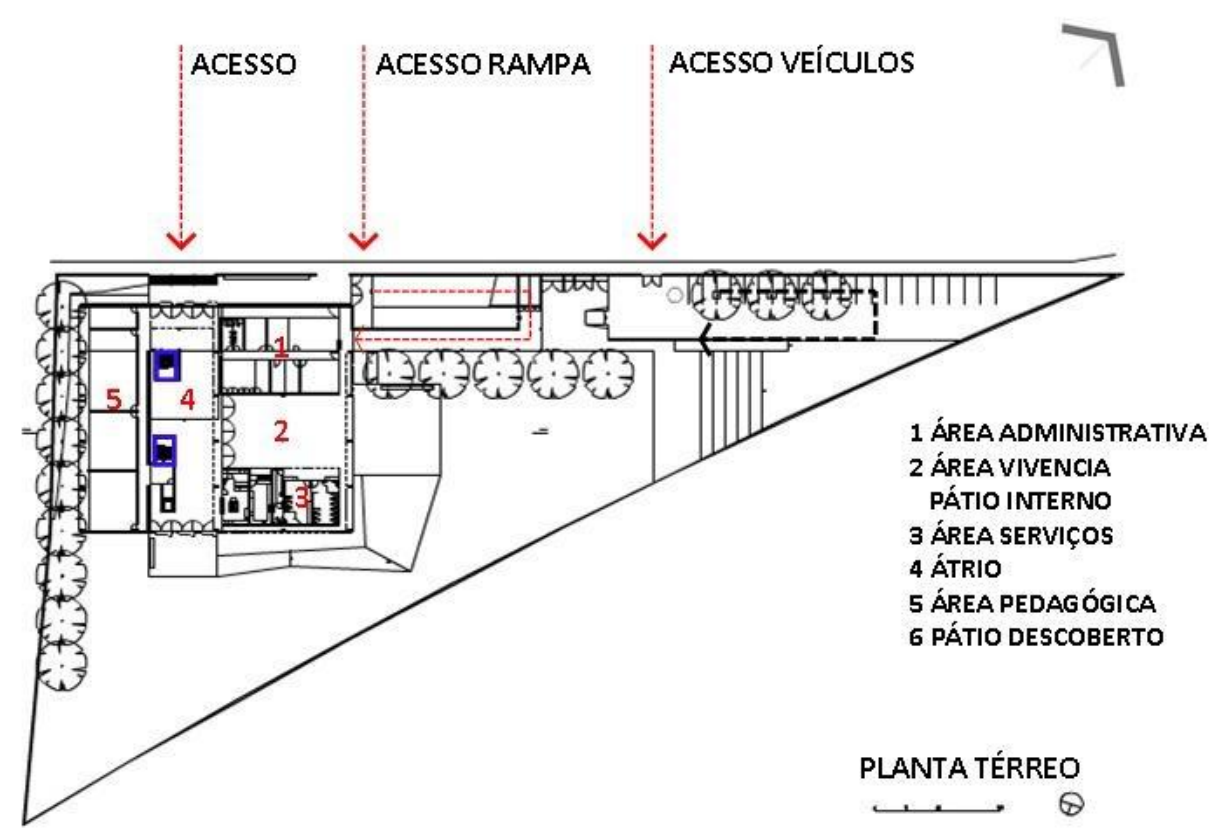

Fig.80 - Planta térreo Escola Estadual Jorn. Roberto Marinho Fonte: http://www.andrademorettin.com.br

Internamente uma rampa metálica estabelece a ligação entre a quadra poliesportiva e o primeiro nível do bloco das salas de aula. 


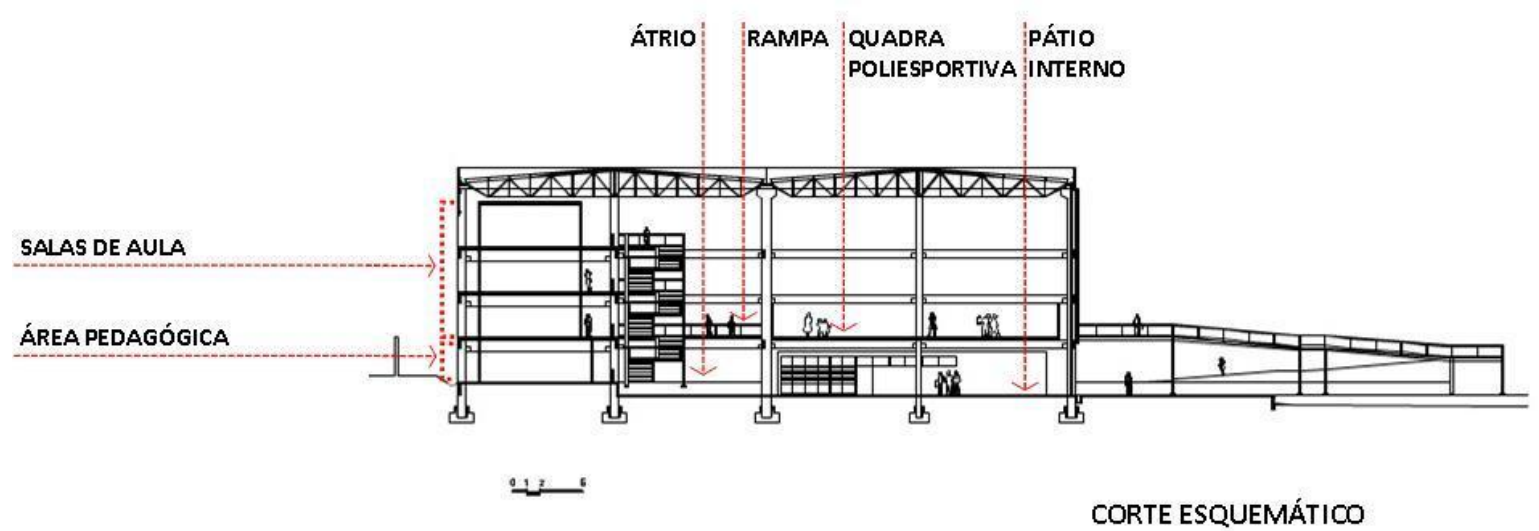

Fig.81 - Corte esquemático Escola Estadual Jorn. Roberto Marinho Fonte: http://www.andrademorettin.com.br

\title{
4.1.6. Materiais e cores
}

\begin{abstract}
“A observação de edifícios industriais nos permitiu reconhecer um repertório compatível com o sistema construtivo proposto e que poderia facilmente ser incorporado ao programa de uma escola, apresentando bom desempenho e baixo custo". (ANDRADE, set.2005) ${ }^{10}$
\end{abstract}

A opção por componentes industriais leves fez com que a estrutura do pavilhão, préfabricada em concreto, tivesse como vedação - nas fachadas noroeste e sudeste - telhas metálicas pré-pintadas, instaladas horizontalmente e, na fachada nordeste, venezianas industriais de PVC, instaladas verticalmente. Na fachada sudoeste, onde estão localizadas as salas de aula, a vedação é em alvenaria de bloco de concreto e esquadrias de ferro, padrão FDE. As esquadrias têm acionamento basculante em suas partes inferiores e fixas na parte superior.

Os espaços destinados às áreas administrativas, de serviços e pedagógicas, no térreo, foram executados em alvenaria de bloco de concreto, recebendo originalmente pintura na cor branca. Devido à padronização na pintura das escolas estaduais, atualmente as cores adotadas são o amarelo, o verde, a cor laranja com pouca saturação e o branco. O padrão atual para as salas de aula prevê pintura com tinta a óleo verde até $1,90 \mathrm{~m}$ do piso e branca na parte superior e no teto.

\footnotetext{
${ }^{10}$ Texto publicado em http://www.vitruvius.com.br/revistas/read/projetos/05.057/2529?page=10, em setembro de 2005 intitulado $7^{\circ}$ Prêmio Jovens Arquitetos 2005.
} 
Uma estrutura metálica com pintura branca suporta a cobertura em telha metálica opaca, com isolamento termo-acústico, sobre o bloco das salas de aula e da quadra poliesportiva. Sobre a rua interna, a cobertura é em telha trapezoidal translúcida de policarbonato.

O revestimento de piso das áreas administrativas, pedagógicas e das salas de aula é cerâmico, enquanto a rua interna, o pátio coberto e a quadra poliesportiva possuem piso cimentício.

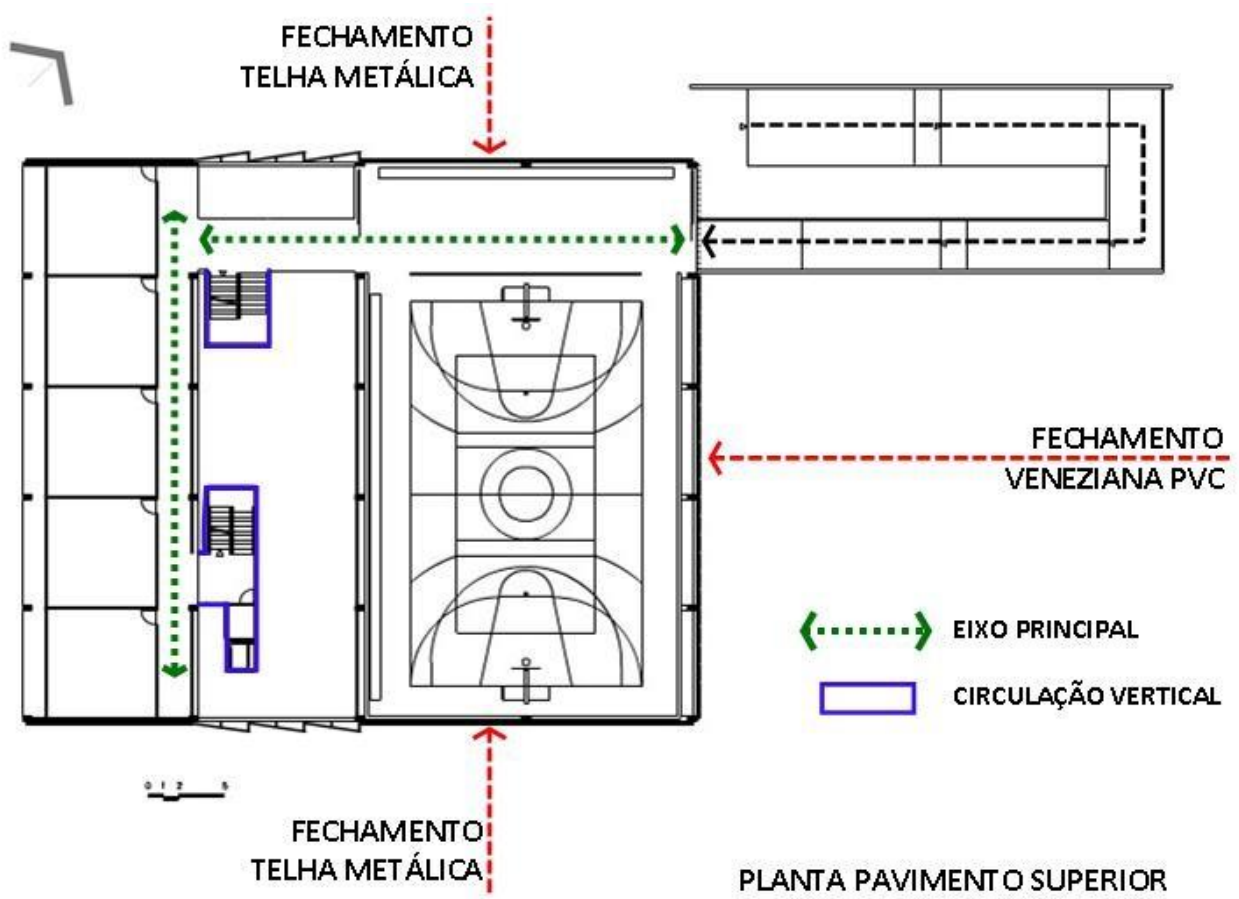

Fig.82 - Planta pavimento superior Escola Estadual Jorn. Roberto Marinho Fonte: http://www.andrademorettin.com.br

\subsubsection{Iluminação natural: aspectos funcionais e subjetivos}

Duas aberturas verticais escamadas, chamadas de guelras pelos autores do projeto, estão localizadas nas fachadas opostas - noroeste e sudeste - alinhadas com a rua interna, favorecendo a ventilação dentro do edifício. 

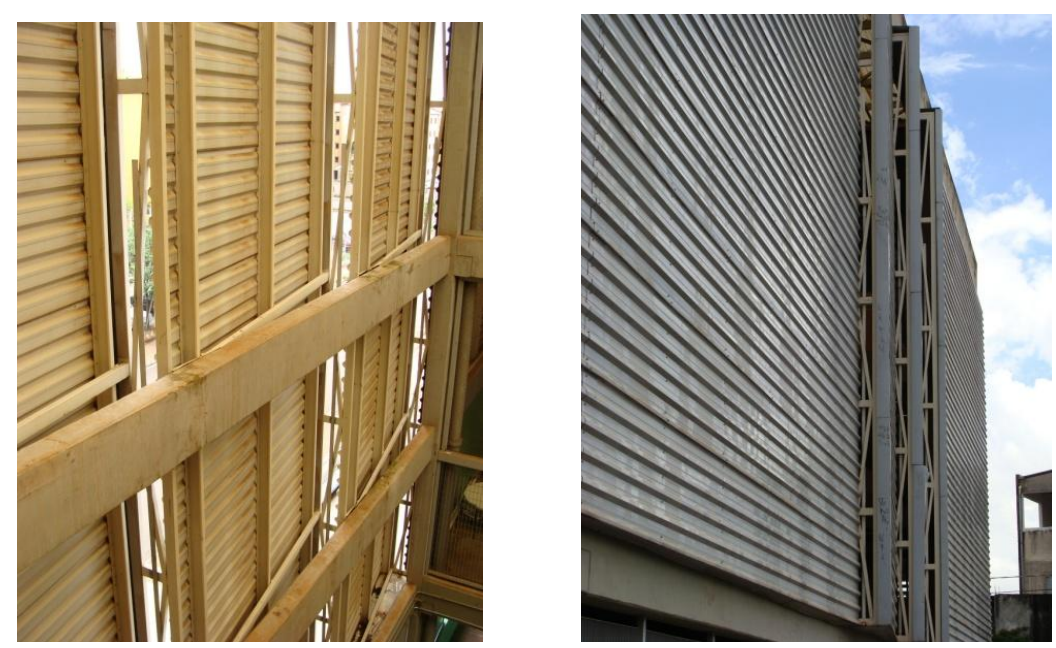

Fig.83 - Escola Estadual Jorn. Roberto Marinho Fonte: acervo pessoal da autora

A fachada sudoeste, a única aberta ao exterior, permite a incidência da luz do dia no bloco que abriga as salas de aula e nas salas pedagógicas localizadas no térreo. As salas de aula possuem os seus fechamentos recuados da estrutura pré-fabricada do edifício. Mesmo estando orientadas para sudoeste, tal gesto projetual, demonstra a preocupação com a incidência direta da luz do dia durante os meses de setembro a fevereiro, nos horários da tarde.

$\mathrm{Na}$ parede que separa as salas de aula da circulação foram propostas aberturas superiores para que a luz difusa incidente através da cobertura translúcida do grande vazio central contribuísse na iluminação. A disposição das aberturas em paredes opostas e posicionadas até a laje do teto faz com que a luz do dia atinja uma maior profundidade no ambiente e favorece a ventilação cruzada.

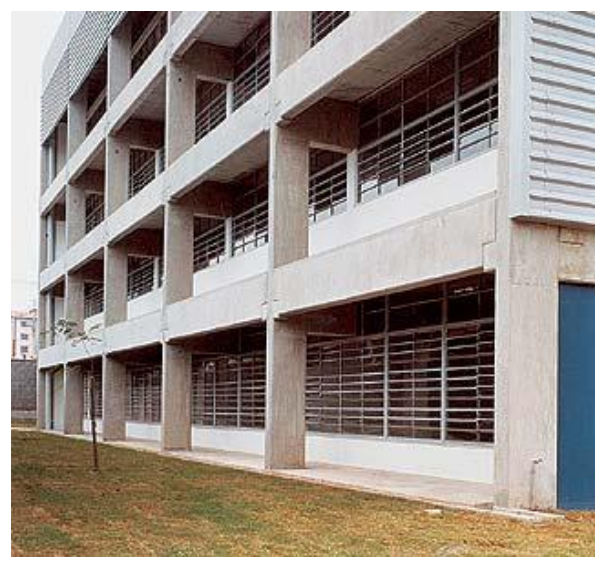

Fig.84 - Escola Estadual Jorn. Roberto Marinho Fonte: http://www.constructalia.com/portugues_br/galeria_de_projetos 

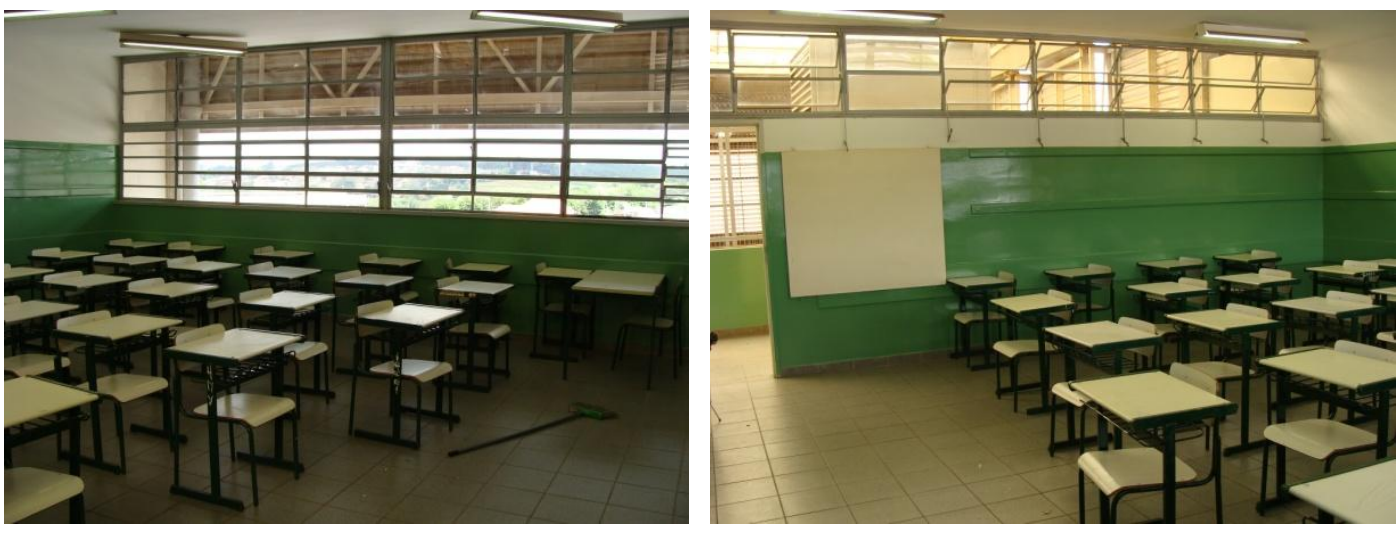

Fig.85 - Escola Estadual Jorn. Roberto Marinho Fonte: acervo pessoal da autora

A entrada da luz do dia na quadra poliesportiva se dá lateralmente através do envoltório translúcido da fachada nordeste. Devido às dimensões da face, percebem-se áreas de reflexão da luz pela superfície do piso.

Fig.86 - Escola Estadual Jorn. Roberto Marinho Fonte: acervo pessoal da autora

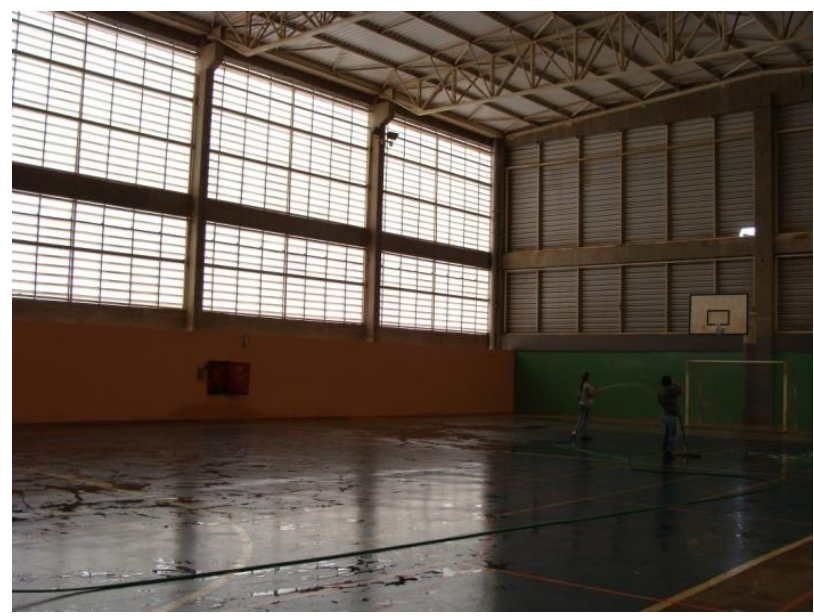

A proposta da iluminação zenital filtrada para o principal eixo de circulação do edifício tornou possível a incidência de luz na circulação entre as salas de aula e também na quadra poliesportiva. 

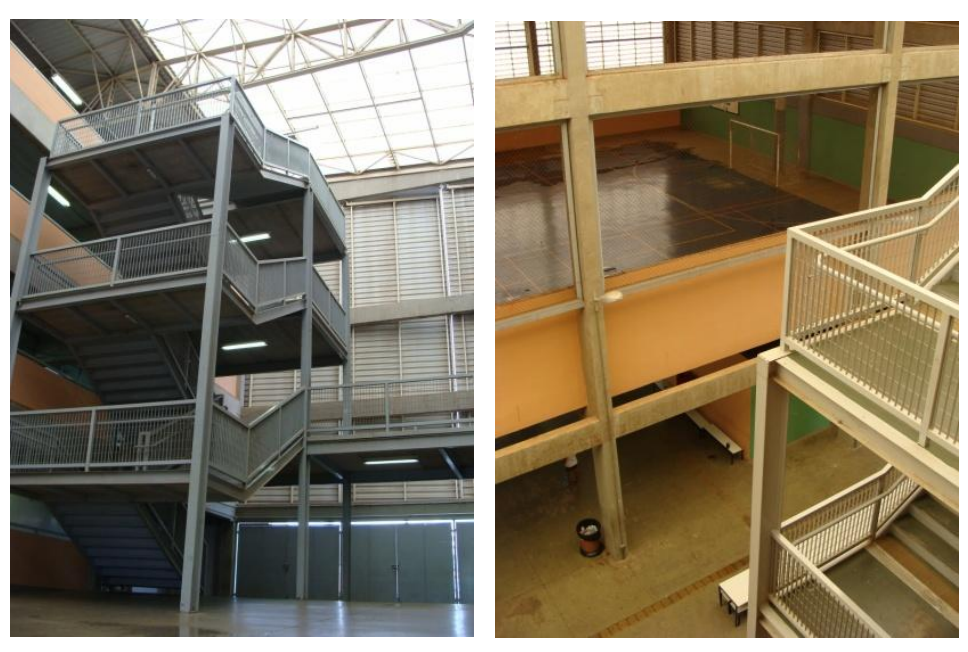

Fig.87 - Escola Estadual Jorn. Roberto Marinho Fonte: acervo pessoal da autora

A permeabilidade visual é percebida com intensidade, no interior do edifício, apesar da aparente solidez transmitida por seu envelopamento.

A conexão do vazio vertical com o pátio horizontal sob pilotis aproxima os espaços diversos, e a luz do dia dá a sua contribuição de maneira significativa para que isso ocorra.

A alternância dos espaços abertos, semiabertos ou fechados promovem uma dinâmica espacial onde os alunos se encontram, trocam experiências ou simplesmente sentam e descansam das atividades escolares.

Fig.88 - Escola Estadual Jorn. Roberto Marinho Fonte: acervo pessoal da autora

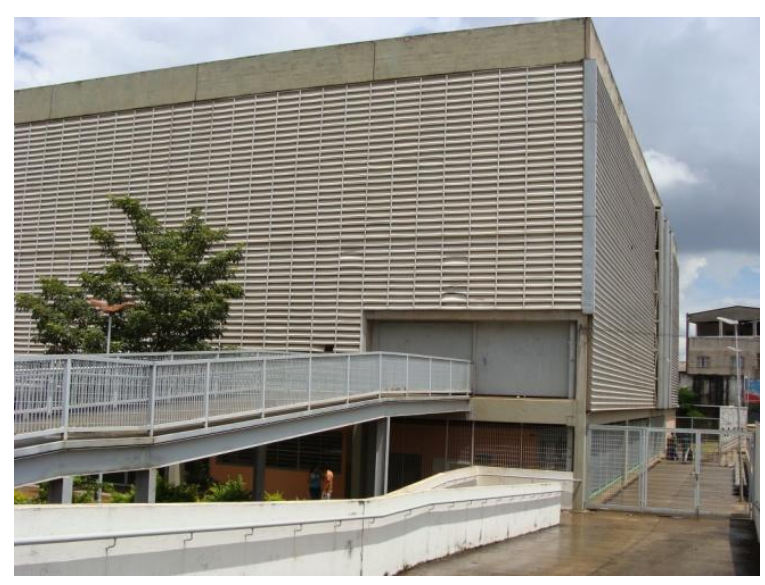




\subsection{EDIFÍCIO II}

RESIDÊNCIA - COORDENADAS $23^{\circ} 26^{\prime} 17^{\prime \prime} \mathrm{S}, 4^{\circ} 00^{\prime} 12^{\prime \prime} 0$

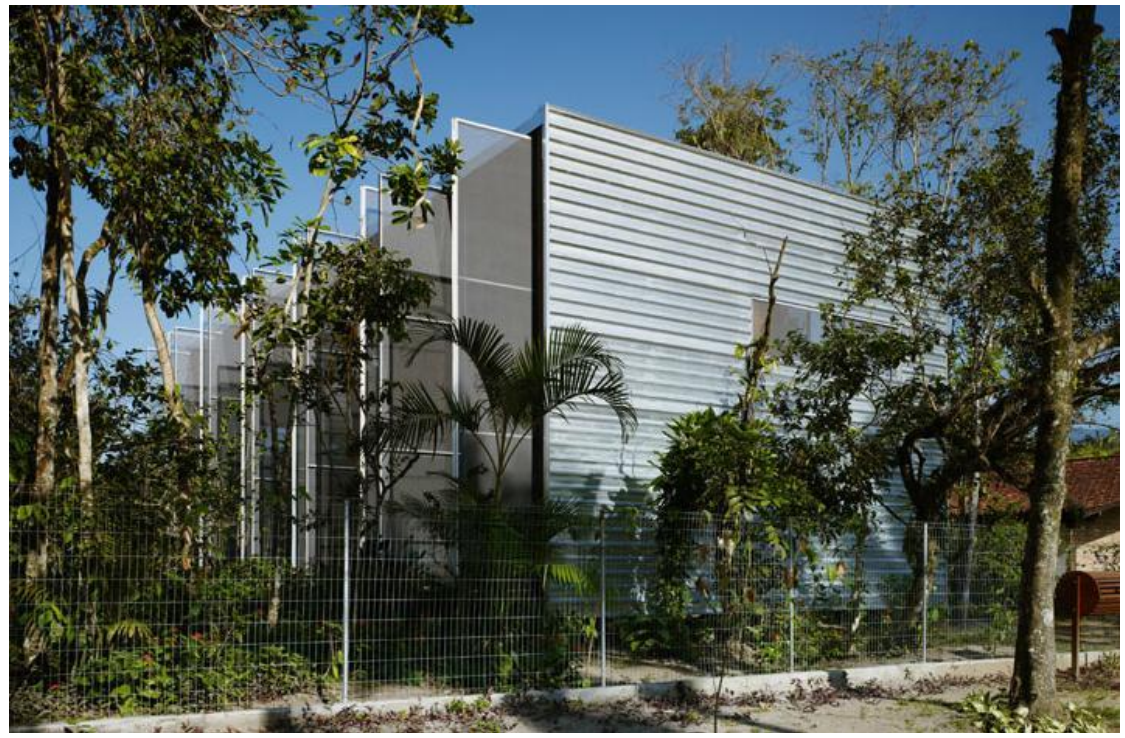

Fig.89 - Residência em Ubatuba, São Paulo Fonte: http://www.andrademorettin.com.br

\subsubsection{Localização}

A residência de veraneio está localizada no litoral norte de São Paulo, em Ubatuba, na Praia de Itamambuca, com área de $220,00 \mathrm{~m} 2$ em um terreno com 500,00m2. O projeto arquitetônico foi realizado em 2006, e a obra concluída em 2007.

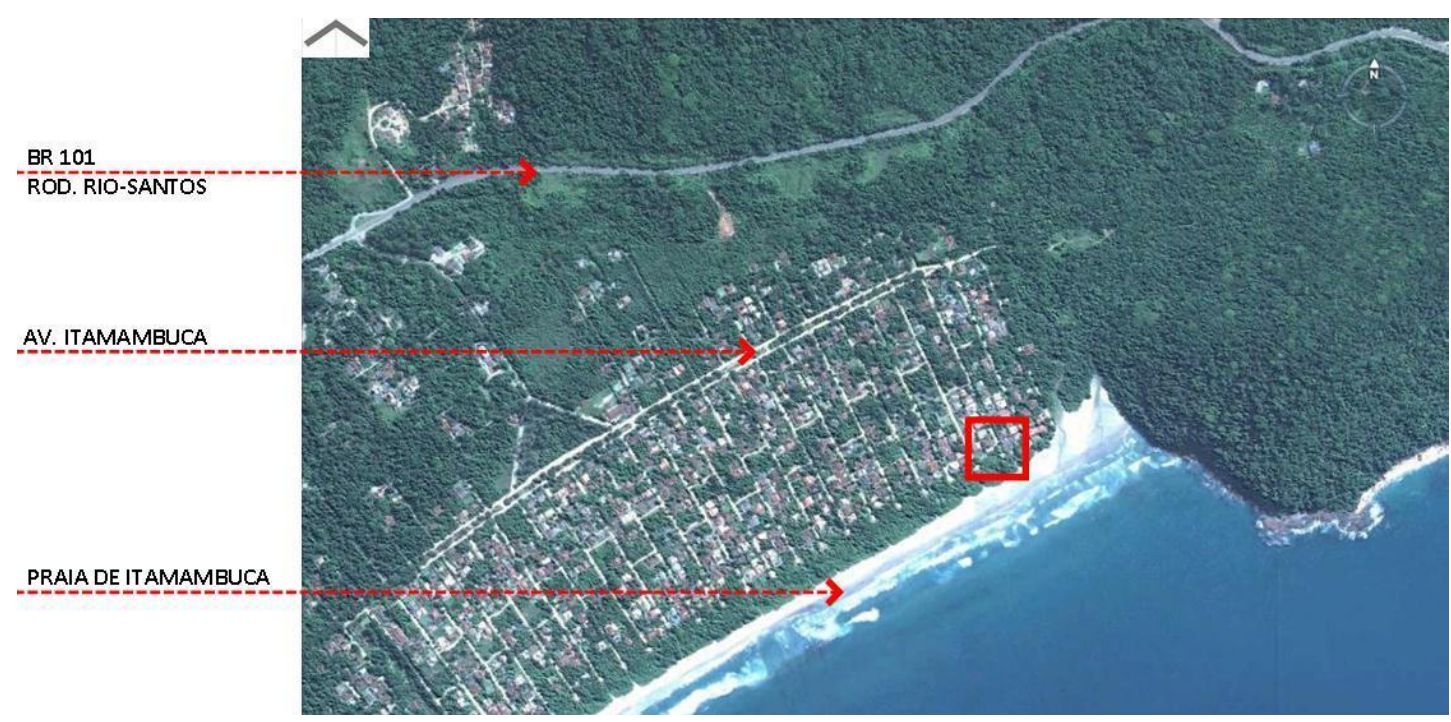

Fig.90 - Situação Residência em Ubatuba, São Paulo 


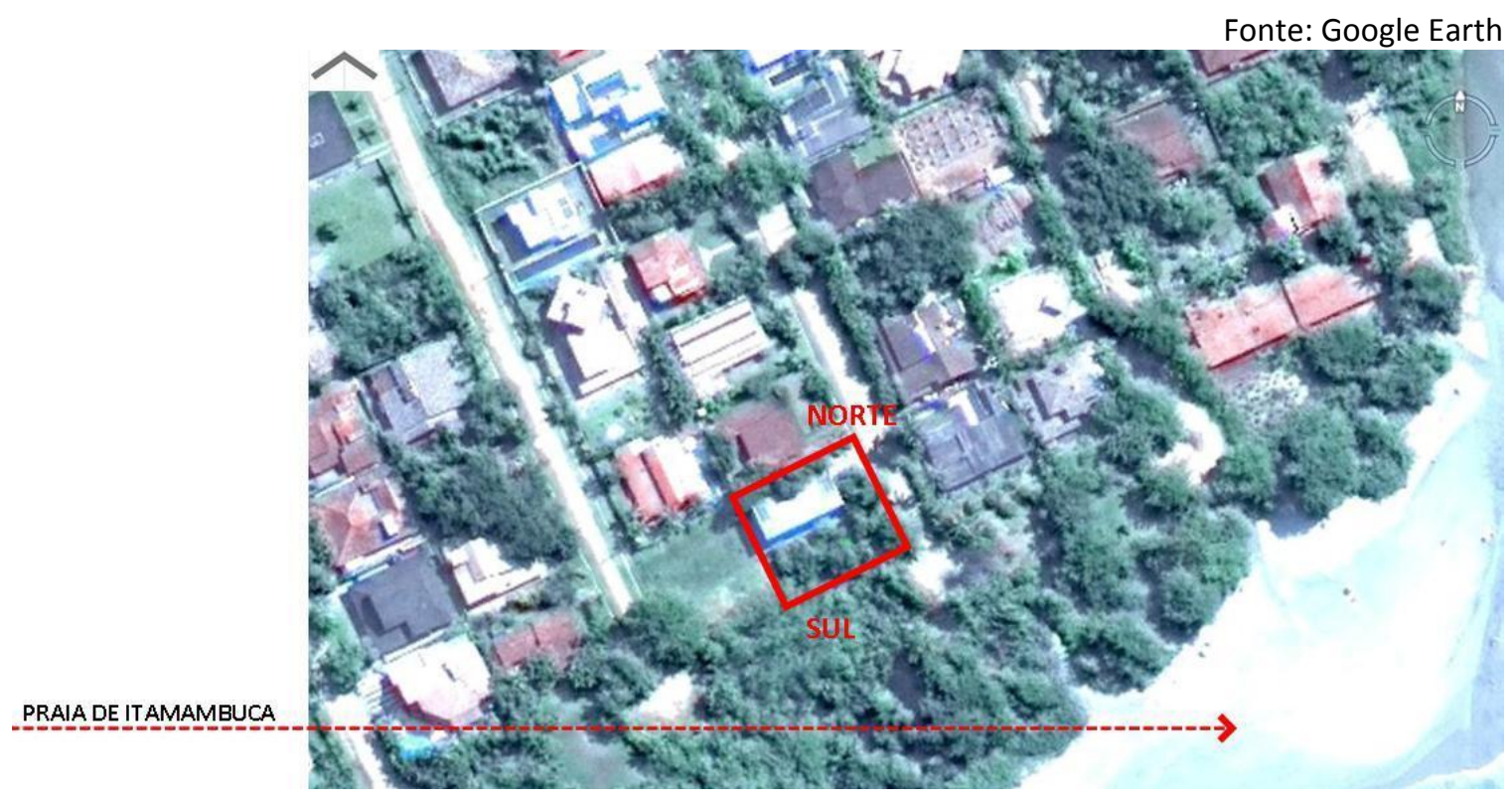

Fig.91 - Situação Residência em Ubatuba, São Paulo Fonte: Google Earth

\subsubsection{Equipe Técnica}

Projeto de Arquitetura: Vinícius Andrade e Marcelo Morettin

Coordenador: Merten Nefs

Colaboradores: Marcio Tanaka, Marcelo Maia Rosa, Marina Mermelstein e Renata Andrulis

Estrutura de Madeira: Hélio Olga

Construção: Vicente Ganzelevich

Elétrica: Nilton José Maziero

Fundação: Pedro Negri

\subsubsection{Breve histórico}

O projeto urbanístico para a Praia de Itamambuca, elaborado pelo arquiteto Sidonio Porto, na década de 1970, previu uma faixa de preservação ambiental entre os terrenos e a praia, conservando o seu aspecto original. 
... “A principal característica da urbanização é que deixamos livre uma faixa de 70 metros entre a linha da água e os primeiros terrenos. A vegetação cresceu de tal forma que da praia não se veem as casas, dá a sensação de uma praia deserta." (PORTO, maio 2010) ${ }^{11}$

\subsubsection{Estudo analítico do edifício: a implantação}

Ao considerar o clima quente e úmido da região, onde a incidência de chuvas é frequente, o projeto teve como proposta a não derrubada de árvores do lote. Os arquitetos definiram a implantação da edificação em uma clareira no terreno, paralelamente ao mar, a fim de coincidir a maior fachada com a vista mais privilegiada e também possibilitar que a brisa do mar fosse uma constante no edifício.

A edificação com dois pavimentos encontra-se a quase oitenta centímetros elevada do solo, apoiada sobre pilotis e tem acesso único.

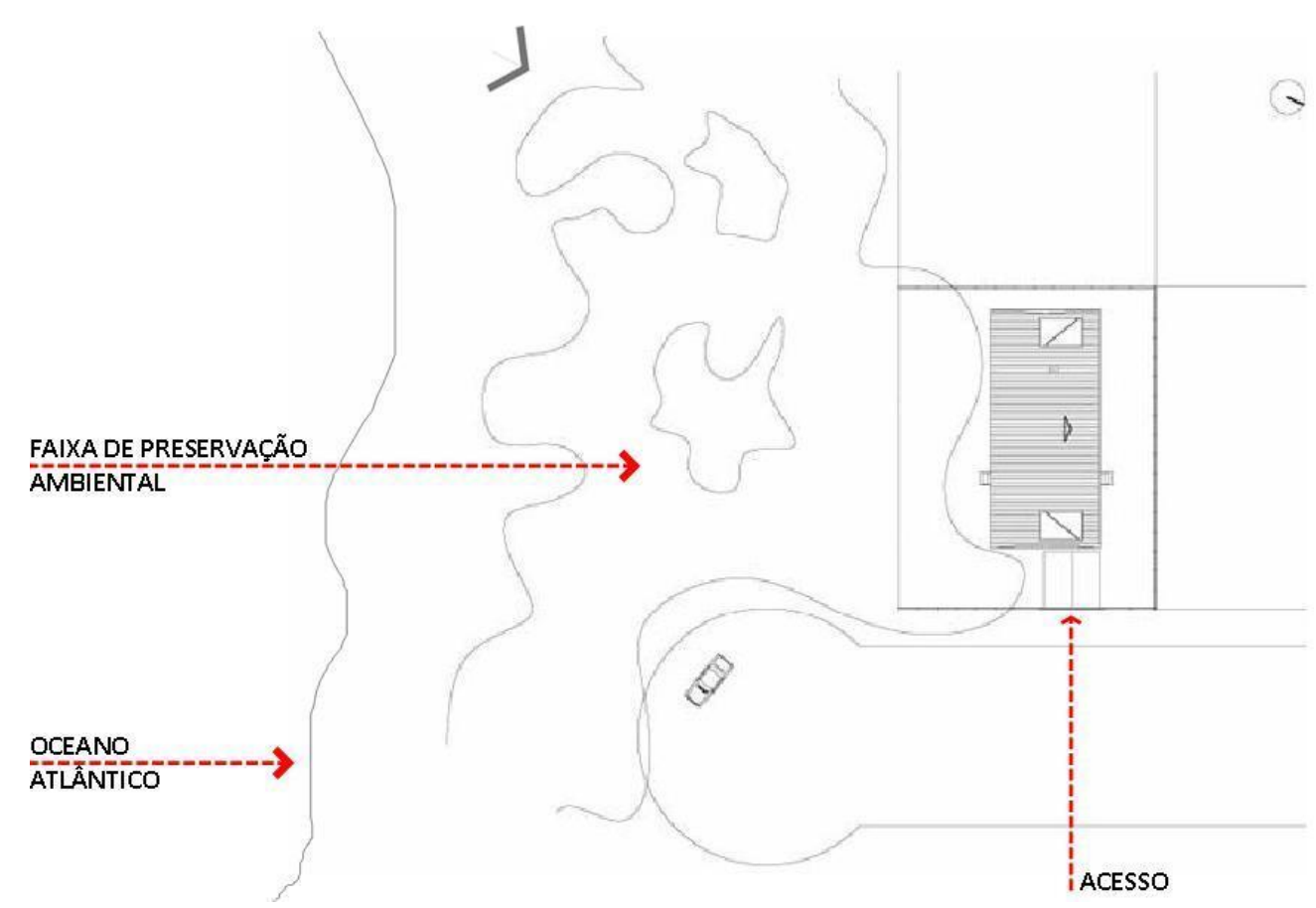

Fig.92 - Implantação Residência em Ubatuba, São Paulo Fonte: http://www.andrademorettin.com.br

\footnotetext{
${ }^{11} \mathrm{O}$ arquiteto conta toda a sua trajetória profissional desde a obra do prédio da CBPO na década de sessenta, entrevista com o arquiteto Sidonio Porto, publicada em 07 de maio de 2010 em http://www.arcoweb.com.br/entrevista/sidonio-porto-o-arquiteto-07-05-2010.html.
} 
Um paralelogramo contido em outro paralelogramo; um volume que abriga e protege outro volume. Os arquitetos propuseram um paralelogramo com 18,00m de comprimento por $8,50 \mathrm{~m}$ de largura, com altura de 7,50m, que abrigasse em seu interior outro paralelogramo com dimensões menores. A diferença de tamanho entre os dois pavilhões possibilitou a existência de um vazio que ocupa toda a altura da edificação, tanto na face sul, que é voltada para o mar, quanto na face oposta, ao norte.

O pavilhão menor abriga a sala, cozinha, um quarto e serviços no térreo, e no pavimento superior, dois quartos, um banheiro e duas varandas. A escada de acesso ao pavimento superior localiza-se no vazio entre os volumes.

OCEANO ATLÂNTICO

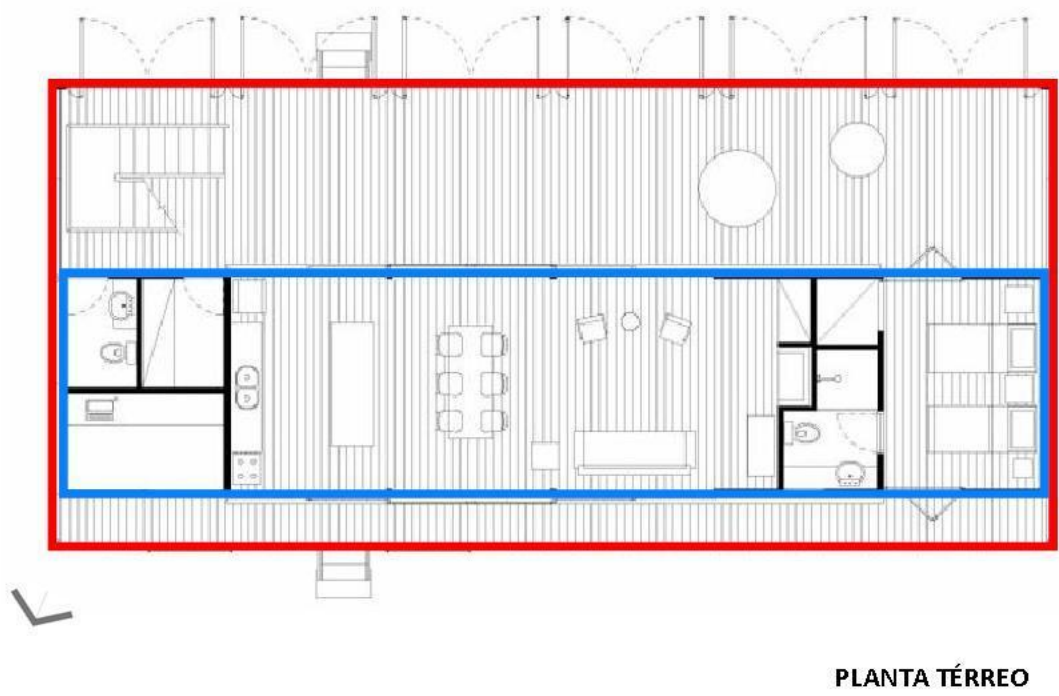

Fig.93 - Planta térreo Residência em Ubatuba, São Paulo Fonte: http://www.andrademorettin.com.br 


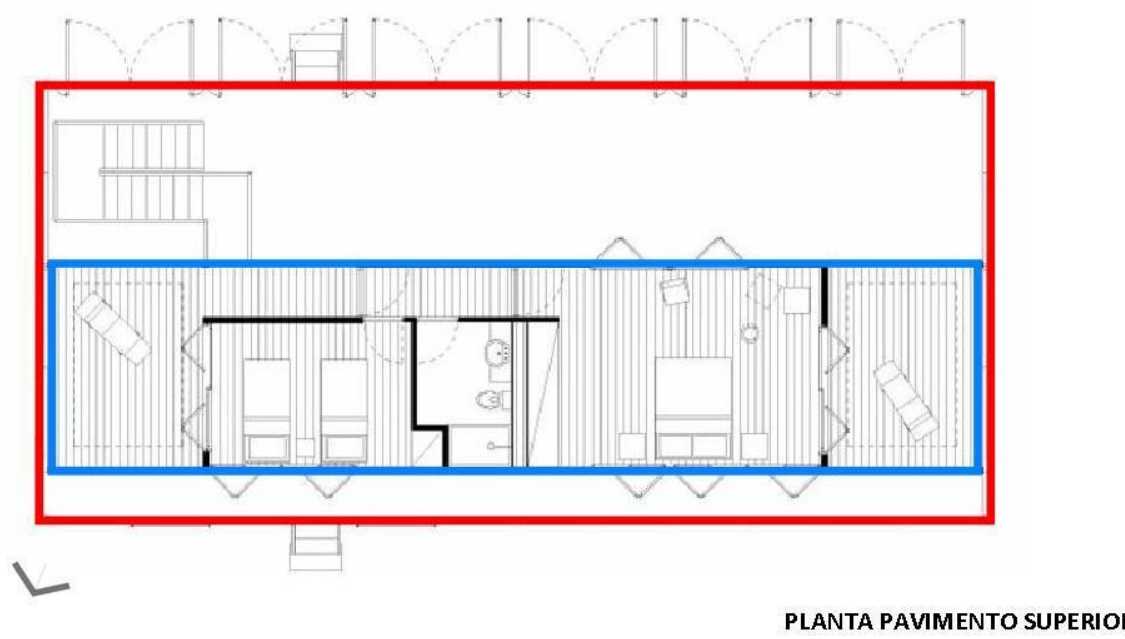

Fig.94 - Planta térreo Residência em Ubatuba, São Paulo Fonte: http://www.andrademorettin.com.br

O fechamento de teto do pavimento superior ocorre abaixo da cobertura do pavilhão externo, possibilitando a existência do pleno entre a cobertura e o forro do segundo pavimento.

As faces menores do pavilhão externo foram executadas com a mesma telha metálica da cobertura. Tal gesto formalizou a existência de um pórtico que abriga, em seu interior, o volume da habitação. As faces voltadas para o norte e para o sul são totalmente permeáveis à luz do dia e ao fluxo de ar, possibilitando que a integração entre espaço interno/externo ocorra em todos os momentos da edificação.

\subsubsection{Materiais e cores}

O sistema construtivo adotado, além de permitir uma montagem rápida e precisa, garantiu uma obra limpa e com pouca geração de resíduos.

Toda a estrutura da casa é em madeira. As faces menores do volume externo, assim como a cobertura, são em telha trapezoidal termo-acústica em aço na cor natural. No fechamento das faces maiores do volume externo foram utilizados painéis com tela mosquiteira de fibra de vidro com PVC em estrutura metálica. Esquadrias de madeira deslizantes com vidro fazem o fechamento translúcido do pavilhão interno no térreo, e placas de OSB ou de gesso acartonado fazem os fechamentos opacos nesse mesmo piso. No 
pavimento superior, os fechamentos internos são em placas de gesso acartonado e os externos, em placas de OSB na cor natural.

Todo o piso da edificação é em madeira: configuração de tábuas internamente e de deck no vazio entre os volumes.
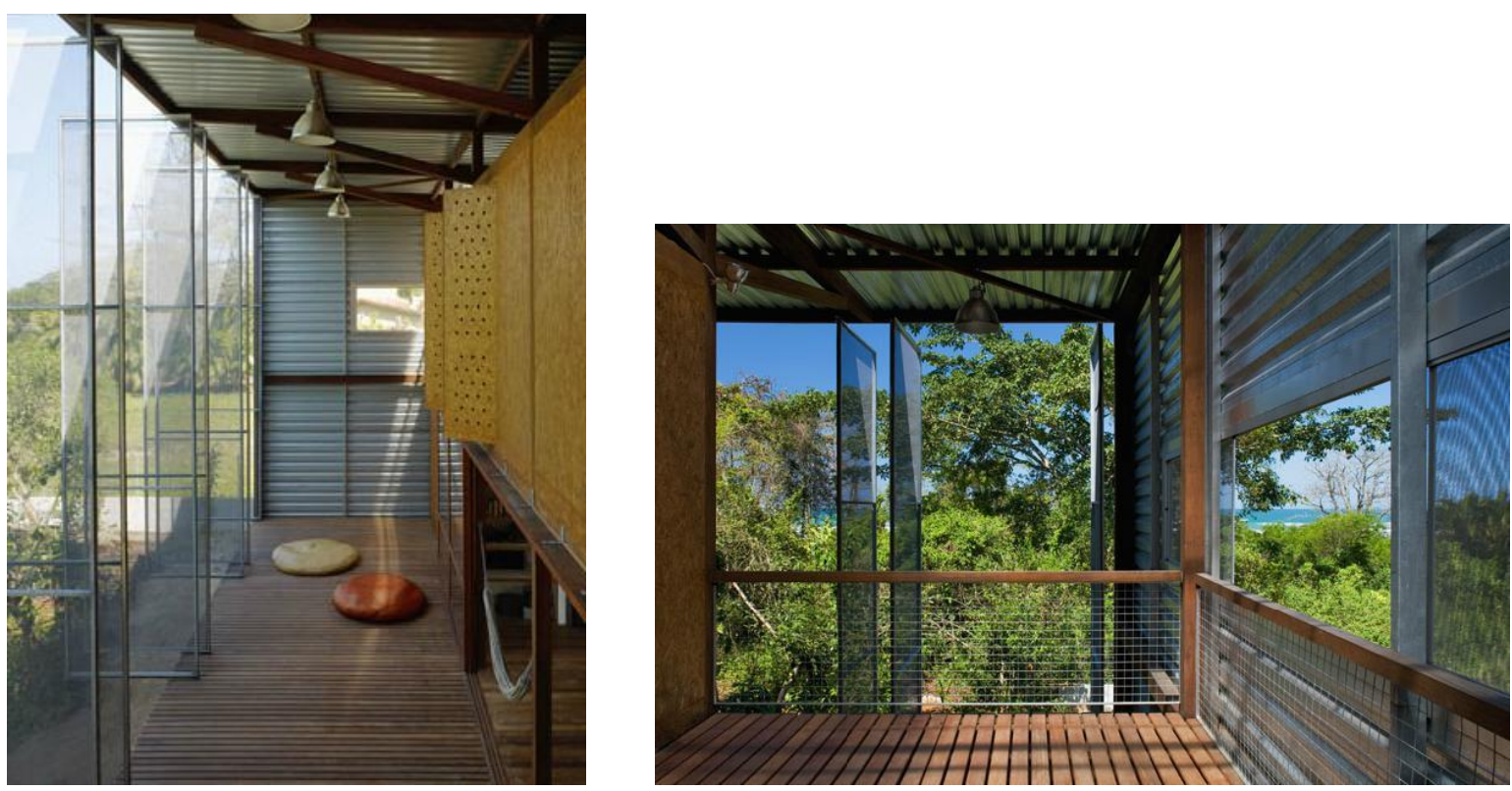

Fig.95 - Residência em Ubatuba, São Paulo Fonte: http://www.andrademorettin.com.br

\subsubsection{Iluminação natural: aspectos funcionais e subjetivos}

A edificação é totalmente permissiva à entrada da luz.

Os painéis translúcidos que fazem o fechamento do volume externo são pivotantes na face sul e deslizantes na face norte do edifício. No volume interno, esquadrias de madeira com vidro translúcido deslizantes permitem a entrada da luz do dia e protegem o interior da edificação. Painéis opacos em placas OSB com orifícios e abertura do tipo camarão fazem a vedação externa dos espaços do piso superior e, internamente foi utilizada a mesma tipologia de esquadria do térreo.

Duas aberturas em faces opostas, nas empenas metálicas, garantem a visão da rua e dos fundos do terreno. 
Característico da produção dos arquitetos, os sucessivos fechamentos criam espaços intersticiais que contribuem para o condicionamento térmico do edifício e favorecem que a entrada da luz do dia ocorra de maneira mais difusa na edificação.

Apesar da profusão da luz do dia, não são percebidos ofuscamentos ou reflexões causadas por superfícies que conformam os espaços.

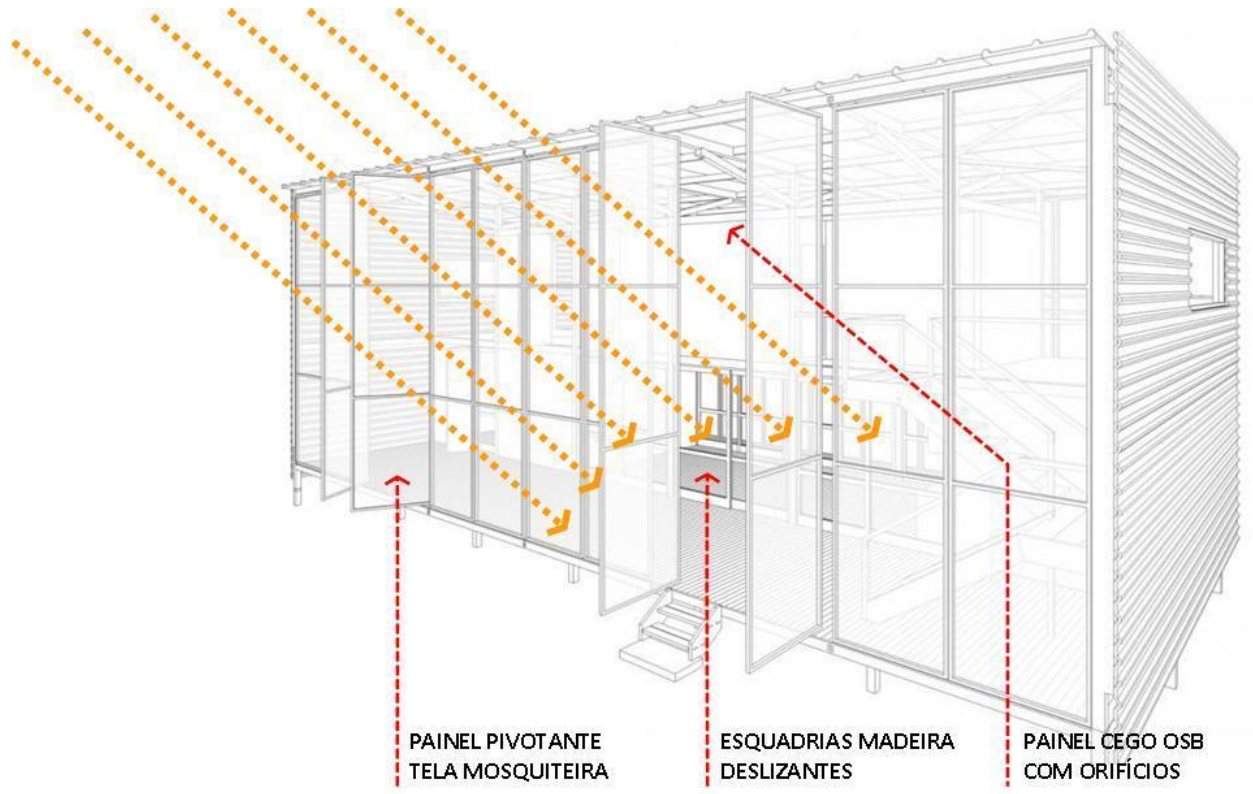

Fig.96 - Residência em Ubatuba, São Paulo Fonte: http://www.archdaily.com.br/15140/residencia-rr-andrade-morettin-arquitetosassociados/andrademorettin_rr_montagem_09-copy/

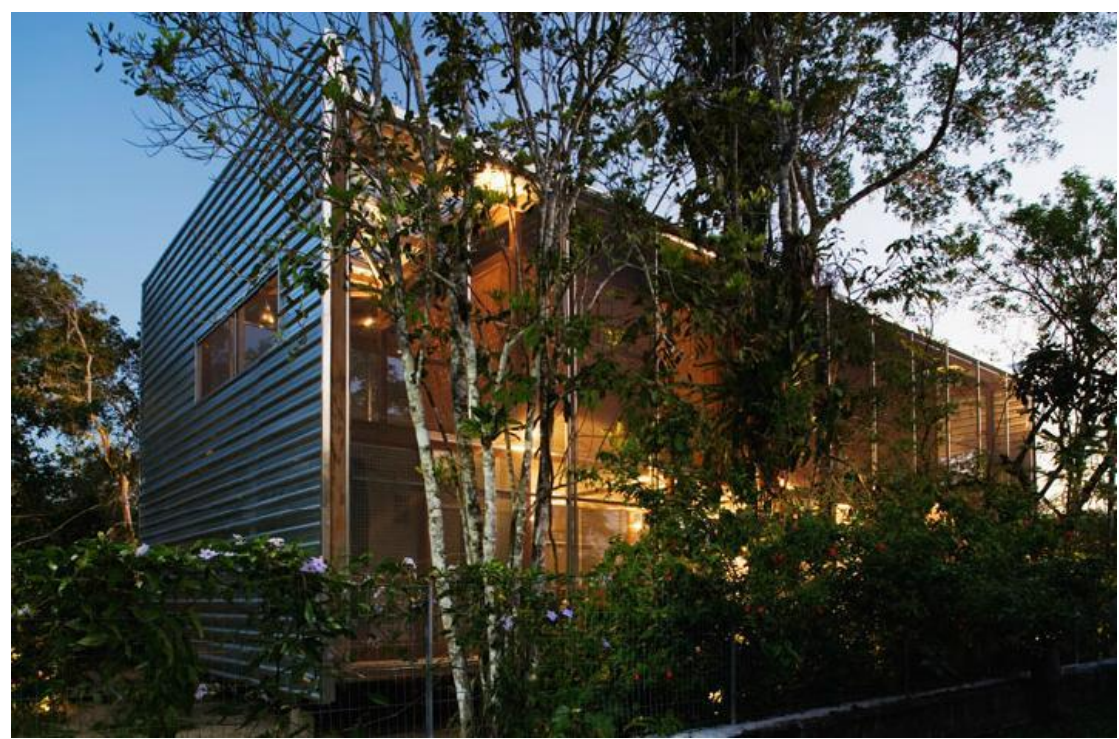

Fig.97 - Residência em Ubatuba, São Paulo Fonte: http://www.andrademorettin.com.br 
As alternâncias entre faces iluminadas e fachadas cegas e a construção de transparências são gestos recorrentes no trabalho dos arquitetos.

O edifício revela o seu interior sutilmente através de uma sequência de filtros que permite o olhar externo sem perder a sua privacidade.

A pele exterior funciona como um regulador climático que permite a entrada da luz do dia de forma filtrada e, ao mesmo tempo, suaviza o impacto visual do edifício no contexto exuberante onde está inserido.

A adoção de sistemas construtivos pré-fabricados ou industrializados reflete a preocupação dos profissionais com a forma de construir, na busca por processos limpos e racionais para a produção do ambiente construído.

“No domínio formal das técnicas industriais de construção, a arquitetura de Andrade e Morettin encontra um meio. Na tensão entre afirmação da ordem e a aleatoriedade da vida, encontra um sentido. Na tênue transparência dos seus volumes construídos, encontra uma poética". (ANELLI, 2011, p.37) ${ }^{12}$

\footnotetext{
${ }^{12}$ Tênue transparência, texto de Renato Anelli para a Revista Monolito.
} 


\section{CAPÍTULO V}

\section{A VISÃO DA LUZ DO DIA PARA O ARQUITETO CAIO FAGGIN}

Caio Luis Mattei Faggin, arquiteto formado pela Faculdade de Arquitetura e Urbanismo da Universidade de São Paulo - FAUUSP, em 1999, com Doutorado em andamento pela Universitat Politècnica de Catalunya - UPC sobre a produção de Vilanova Artigas, teve, ao longo de sua experiência profissional, contato com escritórios de arquitetura de grande porte na Inglaterra e na Espanha, onde trabalhou no escritório Foster and Partners, na Idom UK Ltd/ACXT e no escritório dos arquitetos Joan Noguè, Txema Onzain e Jordi Roig em Barcelona. Participou e recebeu premiações em concursos de arquitetura, tanto no Brasil quanto no exterior. Atualmente participa do escritório Brasil Habitat Arquitetura, em São Paulo.

Uma inquietude que transparecia desde o período acadêmico fez com que o arquiteto, um ano após se formar, fosse para a Europa e por lá permanecesse por seis anos e meio, em contato constante com a produção arquitetônica europeia. Tal oportunidade Ihe proporcionou a experiência de vivenciar a arquitetura e os edifícios icônicos de maneira diferente e o induziu a reflexões acerca da necessidade de se estar em processo de constante busca e transformação.

Caio Faggin acredita que a arquitetura possa ser uma atividade mais rica quando proposta em constantes grupos de discussão. Para ele, o aporte de ideias de várias pessoas, simultaneamente, pode gerar um projeto arquitetônico mais valioso e mais bem elaborado. Essa convicção sobre o trabalho em equipe tem origem em sua formação acadêmica em que, durante as aulas de Projeto, principalmente com os Professores Paulo Mendes da Rocha e Eduardo Almeida, ocorriam debates coletivos acerca dos trabalhos apresentados pelos alunos, e essa rica experiência contribuiu significativamente para a sua formação.

O aprendizado da iluminação natural em sua formação acadêmica aconteceu de acordo com as ofertas das disciplinas específicas na FAUUSP. Segundo Faggin, houve uma mobilização por parte dos alunos para que as disciplinas de Projeto se servissem das disciplinas da Tecnologia como subsídio para o desenvolvimento dos exercícios propostos nos ateliers. O resultado dessa mobilização foi pontual e contribuiu para uma melhor comunicação temporária entre os Departamentos. 
Durante a sua formação e ainda hoje em sua atividade profissional, os modelos físicos são utilizados para a observação do comportamento da luz do dia no edifício. Em seu cotidiano, as maquetes são executadas para o estudo volumétrico e permitem também a visualização do comportamento da luz do dia no edifício, nas diferentes horas do dia. Além desse recurso, também são utilizadas, como ferramentas auxiliares, as modelagens em 3D para a observação da iluminação natural.

Em seu processo projetual, Caio Faggin revive a sequência de preocupações com a luz do dia, inquietação constante desde a sua formação. Ele entende a luz inicialmente como um plano vertical que irá passar através de uma abertura e, depois, os desdobramentos dessa luz dentro do edifício: como ela será controlada, como será filtrada e quais sensações se pretende gerar no espaço. No desenvolvimento de seus projetos revela uma motivação em aprimorar a compreensão e o domínio em trabalhar a luz do dia enquanto elemento de composição e isso faz com que cada projeto elaborado apresente uma riqueza maior na relação do trato com a luz do dia.

"... a luz te ajuda a revelar a arquitetura e a vivência de um edifício".

(FAGGIN, Apêndice digital)

Para Faggin, o trabalho de Mies Van der Rohe se apresenta como um referencial ao se trabalhar com a luz do dia enquanto elemento de composição do espaço. A Nova Galeria Nacional em Berlim, espaço que abriga uma coleção de esculturas e pinturas europeias do século XX, representa a síntese desse pensamento. Além da obra de Mies Van der Rohe, Norman Foster, Renzo Piano e Peter Zumthor também são citados como arquitetos que primam pelo desenho da luz do dia em seus projetos. 
5.1. EDIFÍCIO I:

CENTRO DE SAÚDE - COORDENADAS 39²8'29”N, 0309'11"L

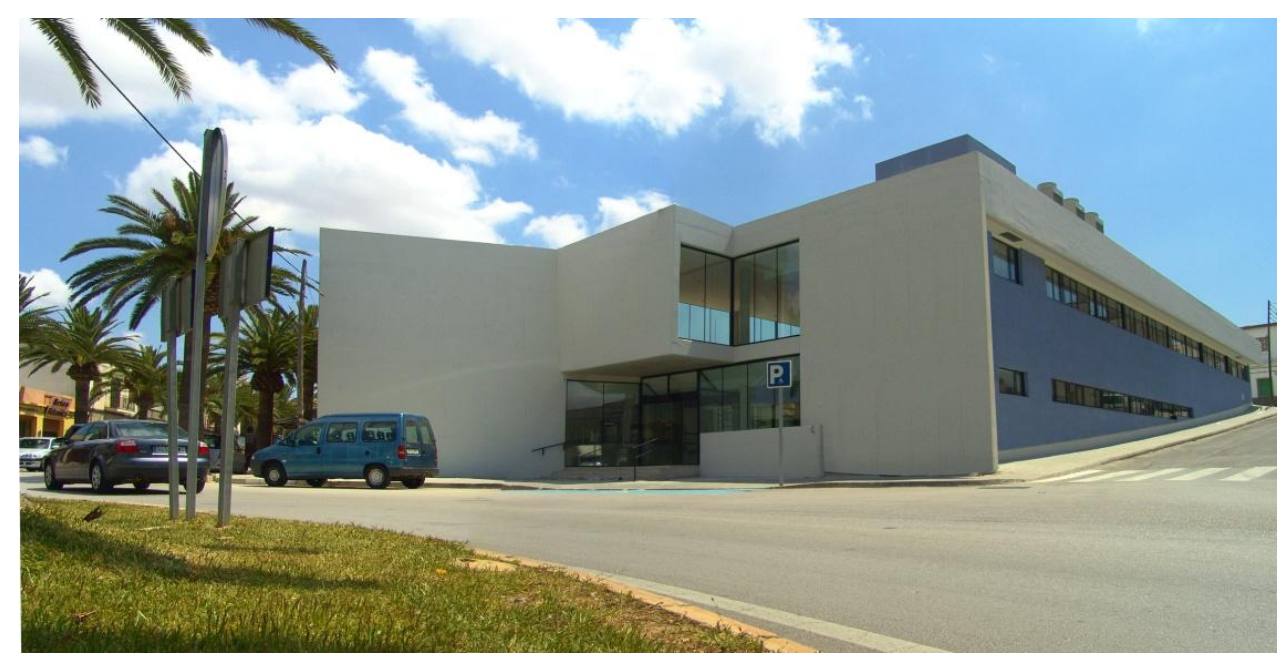

Fig.98 - Centro de Saúde em Felanitx Fonte: acervo pessoal do arquiteto Caio Faggin

\subsubsection{Localização}

O centro de saúde localiza-se na cidade de Felanitx, em Mallorca, na Espanha, com área construída de $3.000,00 \mathrm{~m} 2$ em um terreno com área de $2.425,00 \mathrm{~m} 2$. O projeto arquitetônico foi elaborado em 2005.

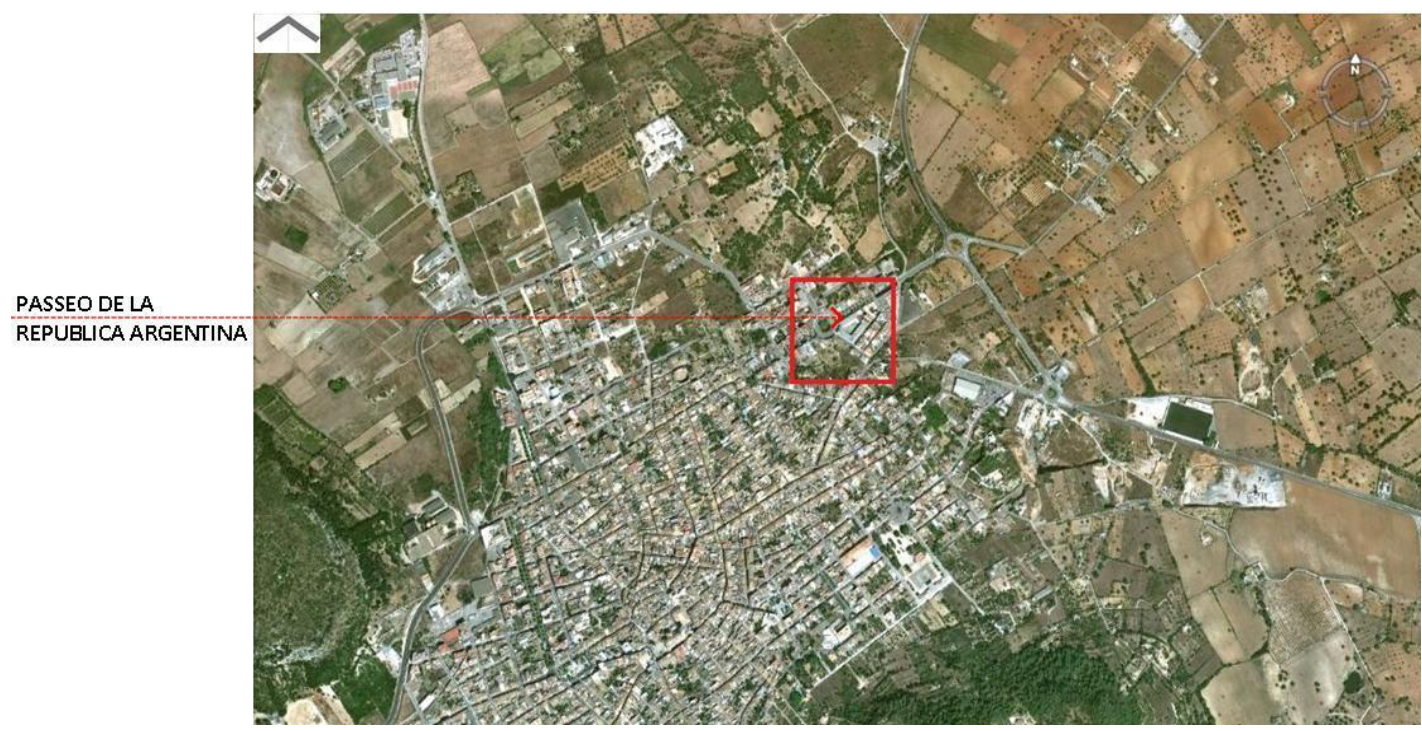

Fig.99 - Situação Centro de Saúde Fonte: Google Earth 


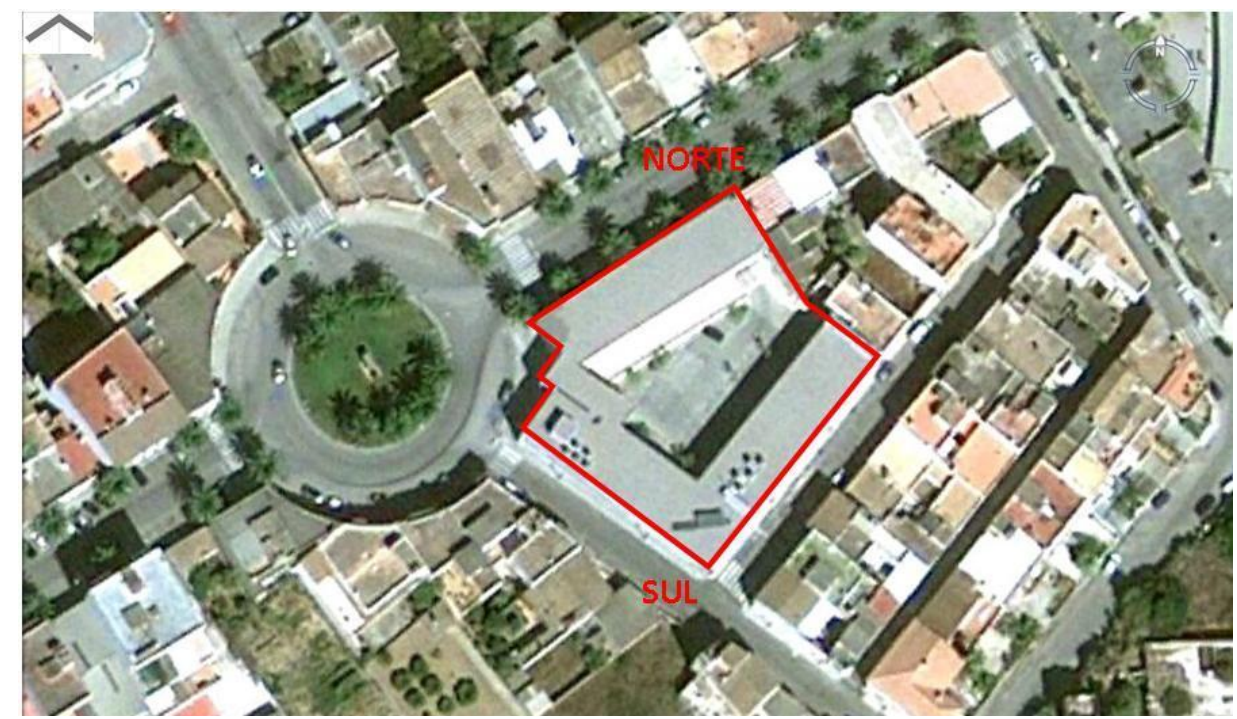

Fig.100 - Situação Centro de Saúde Fonte: Google Earth

\subsubsection{Equipe Técnica}

Projeto de Arquitetura: Caio Mattei Faggin

Coordenador: José Antonio Fernández Usón

Colaboradores: Elena Romero Castillo, Maria Antonia Freyre, Sara Baldasano, Francisco Jose Gonzalez, Hugo Palmero Abraham Muley

\subsubsection{Breve histórico}

O terreno possui frente para três ruas e, obrigatoriamente pelas normas urbanísticas municipais, deveria estar alinhado nas três faces. A profundidade edificável, que é um termo urbanístico usado na Espanha, determinava como 14,00 metros, a partir do alinhamento predial e sem recuo, a possibilidade de se edificar. Obrigatoriamente a conformação do edifício seria a de uma ferradura, com as faces paralelas às três ruas, possibilitando, dessa forma, a existência de um pátio na parte interna do lote.

\subsubsection{Estudo analítico do edifício: a implantação}

A solução formal adotada pelo arquiteto estabeleceu uma relação direta e transparente do espaço interno com o átrio. Todas as salas de espera dos consultórios assim 
como a área administrativa no pavimento térreo estão voltadas para o átrio. $\mathrm{O}$ arquiteto considerou não ser interessante privilegiar as visuais com o entorno, que apresentava casas de pequeno porte na rua aos fundos, um galpão no Passeo de la Republica Argentina e um canteiro central arborizado,nas áreas de longa permanência.

O acesso de pedestres ao edifício se dá pela esquina enquanto o de veículos para o estacionamento localizado no átrio acontece pela rua lateral.

A configuração do edifício fez com que ele tivesse suas faces voltadas para diferentes orientações.

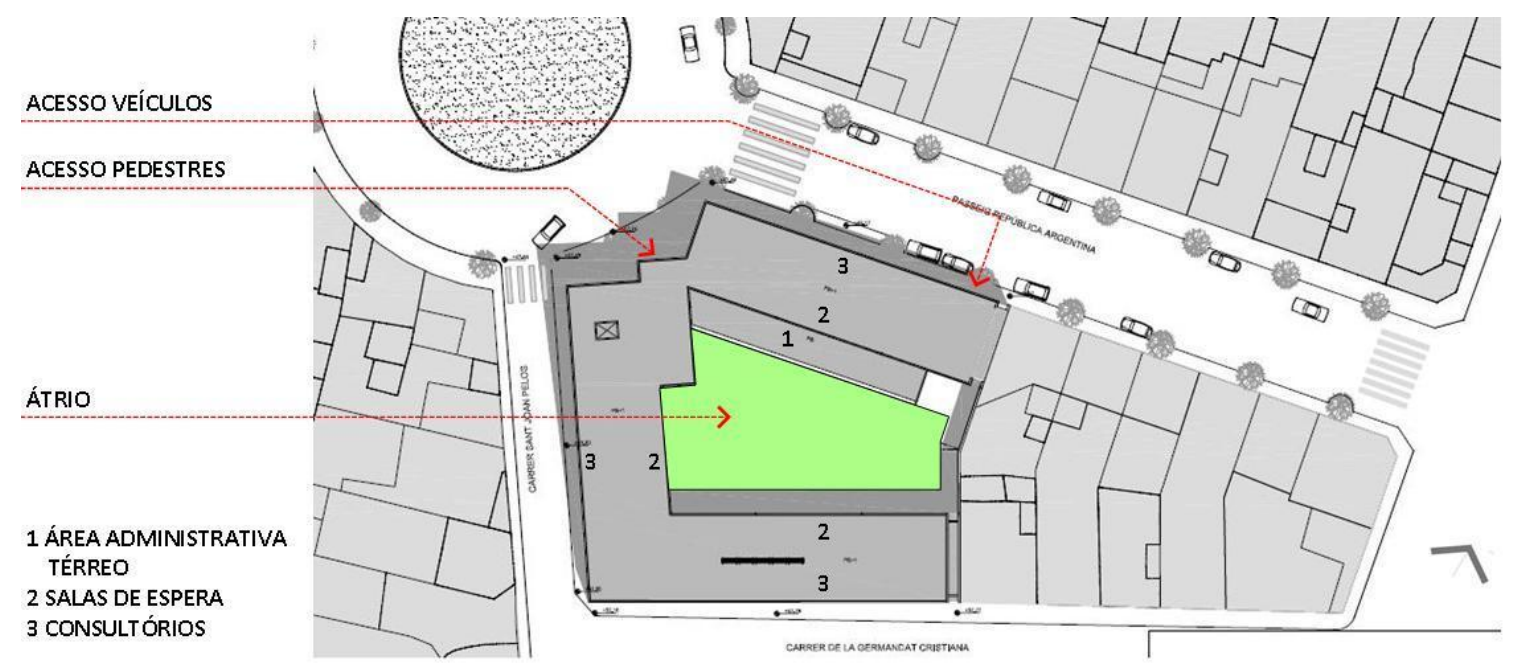

Fig.101 - Implantação Centro de Saúde Fonte: acervo pessoal do arquiteto Caio Faggin

\subsubsection{Composição espacial}

O terreno é circundado por três paralelogramos que formam o átrio. No térreo do volume com face para o Passeo de la Republica Argentina estão localizadas as áreas de emergências médicas e a área administrativa, enquanto que no pavimento superior estão os consultórios pediátricos e a área de espera. No volume com face para o Carrer Sant Joan Pelos, consultórios e áreas de espera estão localizados tanto no térreo quanto no pavimento superior. A área técnica-operacional do Centro de Saúde e as vagas de estacionamento destinadas aos portadores de necessidades especiais estão localizadas no térreo do volume 
com face para o Carrer de la Germandat Cristiana e sobre estas, no pavimento superior, localizam-se consultórios e áreas de espera.

A circulação interna entre os paralelogramos, tanto no térreo quanto no pavimento superior, acontecem em torno do pátio. Junto à esquina, no encontro de dois volumes está a circulação vertical, concentrada e definida por sua volumetria.

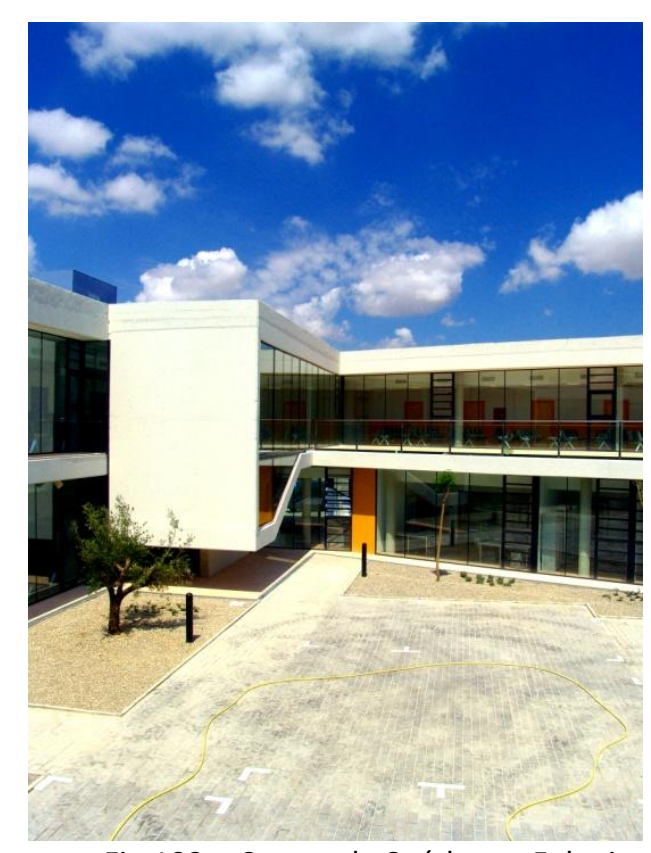

Fig.102 - Centro de Saúde em Felanitx Fonte: acervo pessoal do arquiteto Caio Faggin

Dois eixos paralelos de circulação: um privativo e outro para a circulação do público delimitam a área administrativa e operacional no térreo. Os espaços privativos destinados aos consultórios, enfermarias, sanitários, etc., estão localizados na periferia do edifício. A circulação pelo edifício acontece através das áreas de espera. 


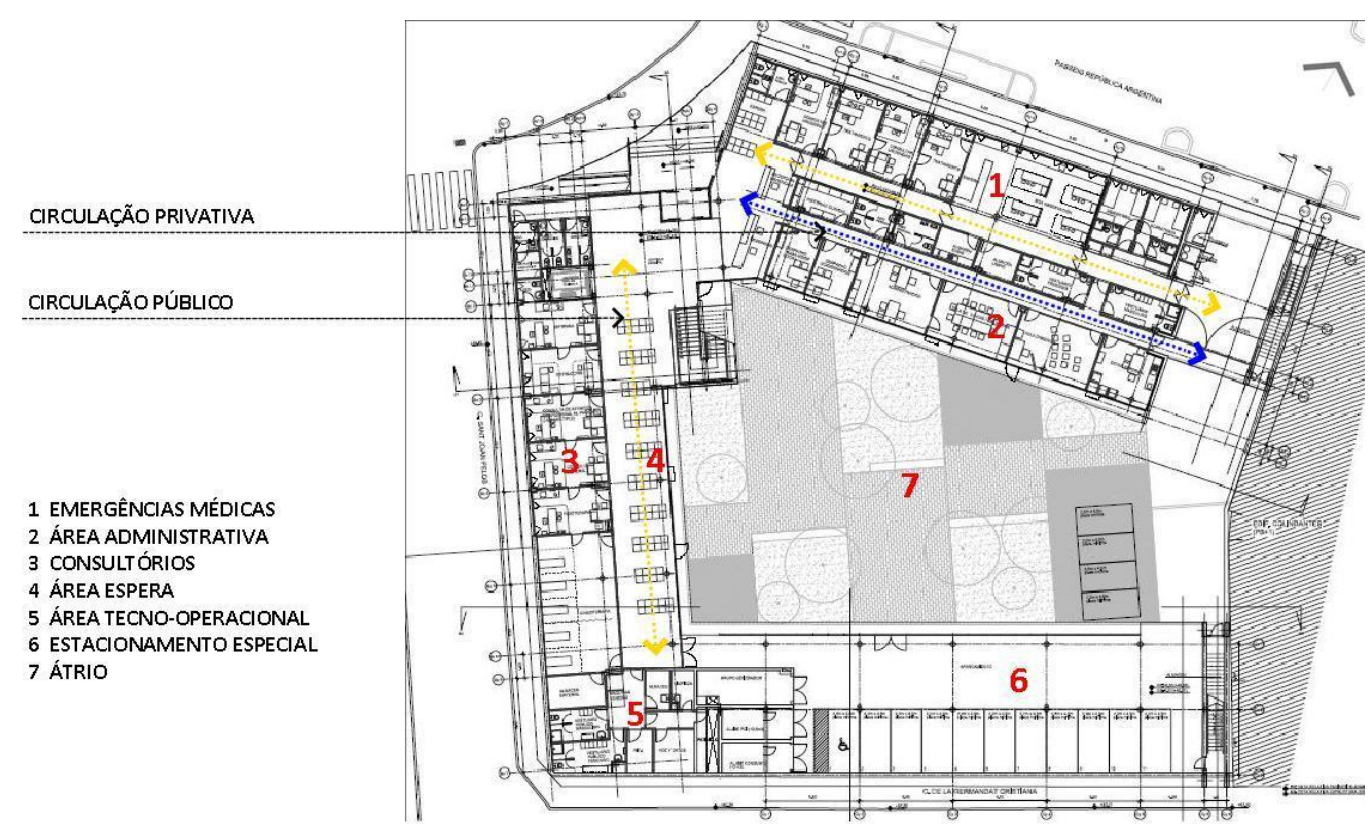

PLANTA TÉRREO

Fig.103 - Planta térreo Centro de Saúde Fonte: acervo pessoal do arquiteto Caio Faggin

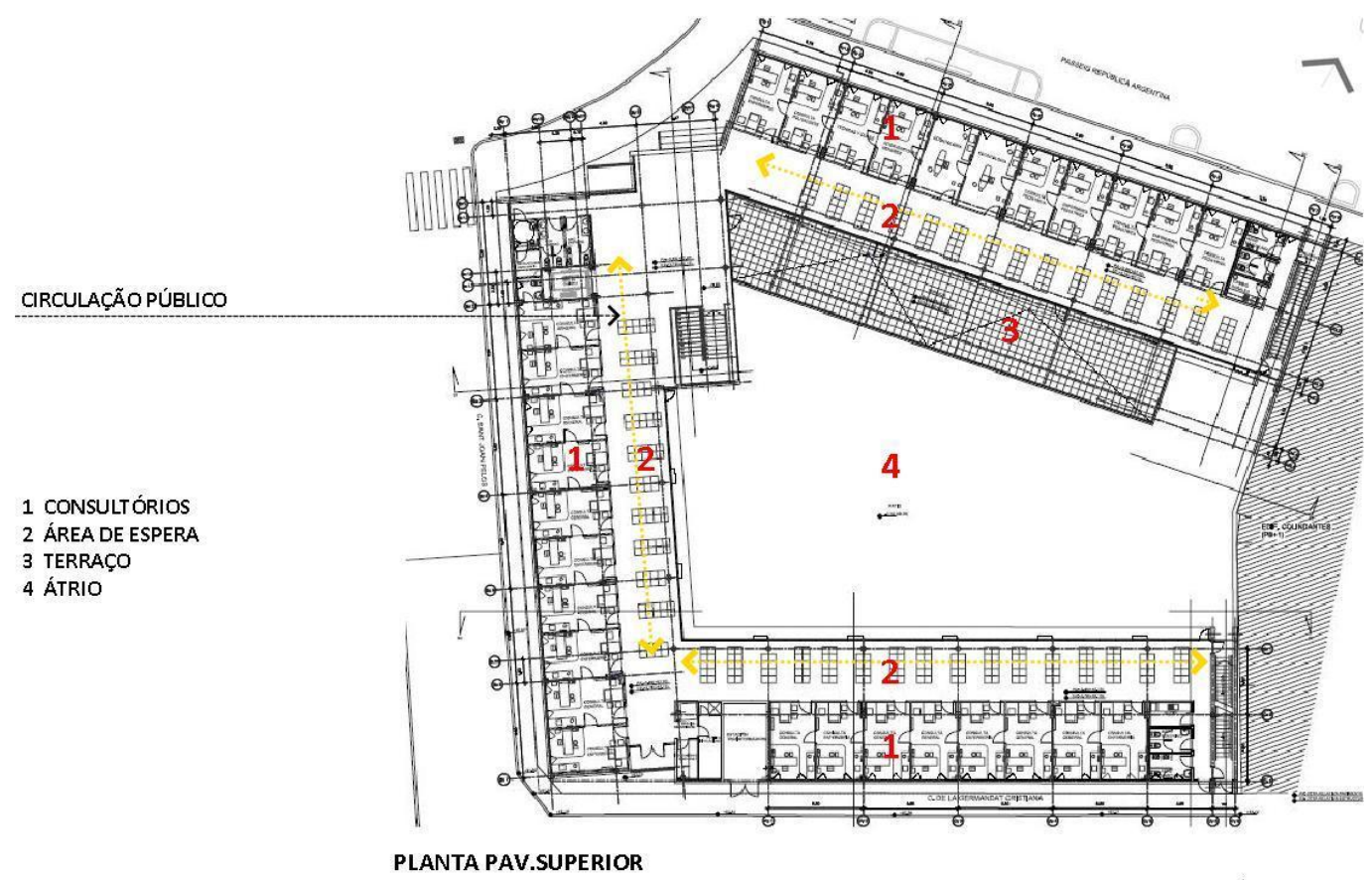

Fig.104 - Planta pavimento superior Centro de Saúde Fonte: acervo pessoal do arquiteto Caio Faggin

\subsubsection{Materiais e cores}

A estrutura do edifício é em concreto, com fechamento externo em blocos de concreto, e os fechamentos internos são todos em painéis de gesso acartonado hidrófugos 
com miolo em lã de rocha a fim de garantir isolamento térmico e acústico aos ambientes. As paredes internas que dividem as áreas de espera e os consultórios são revestidas até a altura de um metro e vinte centímetros, com chapa melamínica nas cores amarelo e azul.

As cores foram utilizadas internamente nas chapas melamínicas, portas, caixilhos e mobiliário para marcar a setorização do espaço: o amarelo, na área de emergências médicas no térreo e pediatria no pavimento superior; e a cor azul nas áreas de consultórios e de espera nos dois pavimentos. Essas mesmas cores se repetem nas fachadas externas, fazendo com que o usuário possa, a partir da rua, identificar as áreas internas do edifício. Além do amarelo e azul, o arquiteto utilizou a cor branca nos demais elementos do edifício.

A cobertura é em laje de concreto impermeabilizada.

O piso que reveste toda a edificação é à base de resina poliéster, o que contribui para a sua fácil manutenção.

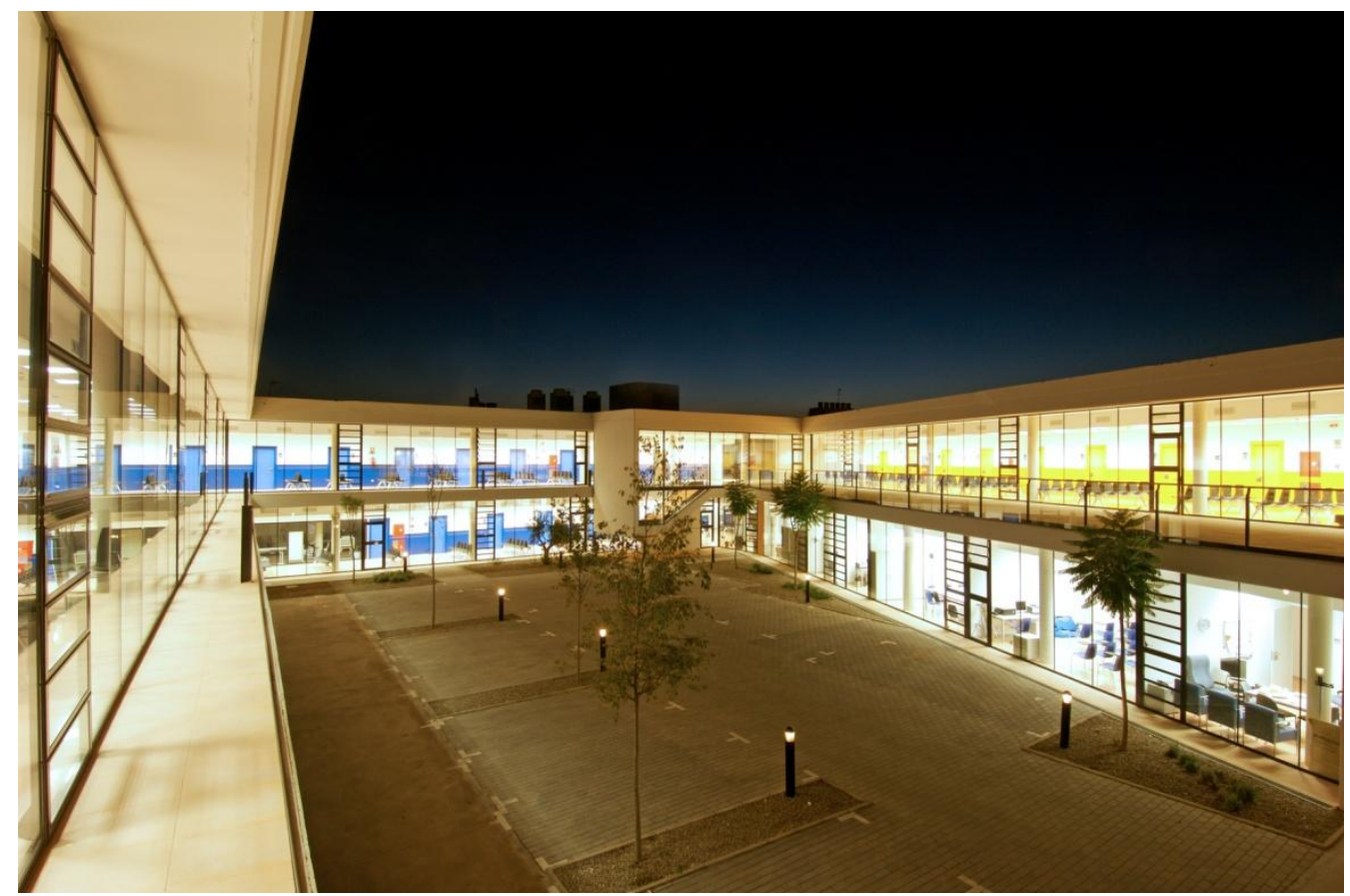

Fig.105 - Centro de Saúde em Felanitx Fonte: acervo pessoal do arquiteto Caio Faggin

\subsubsection{Iluminação natural: aspectos funcionais e subjetivos}

Por entender que as áreas de espera são de permanência mais longa e subjetiva, onde o paciente vivencia o espaço por um tempo maior, diferentemente das áreas dos 
consultórios, onde a permanência do paciente é de curta duração e mais funcional, o arquiteto propôs que as faces voltadas para o átrio fossem totalmente translúcidas e que ocupassem todo o pé direito, tanto no térreo quanto no pavimento superior. Nos consultórios, as aberturas foram propostas a partir de um metro e meio do piso a fim de garantir maior privacidade ao espaço, permitindo, ao mesmo tempo, a integração com o exterior e privilegiando tanto a iluminação quanto a ventilação natural.

A proposta do fechamento translúcido das áreas de espera acontece de maneira recuada às fachadas, nos dois pavimentos. Tal gesto projetual possibilitou a existência de uma marquise que, em determinados horários do dia, acaba produzindo uma área de sombra junto às faces do edifício e também no átrio.

$\mathrm{Na}$ área dos consultórios, as esquadrias em alumínio propostas têm duplo acionamento pivotante: tanto vertical quanto horizontal. Os painéis translúcidos de fechamento das áreas de espera são fixos e obedecem a uma modulação que é interrompida em determinados intervalos por painéis basculantes.

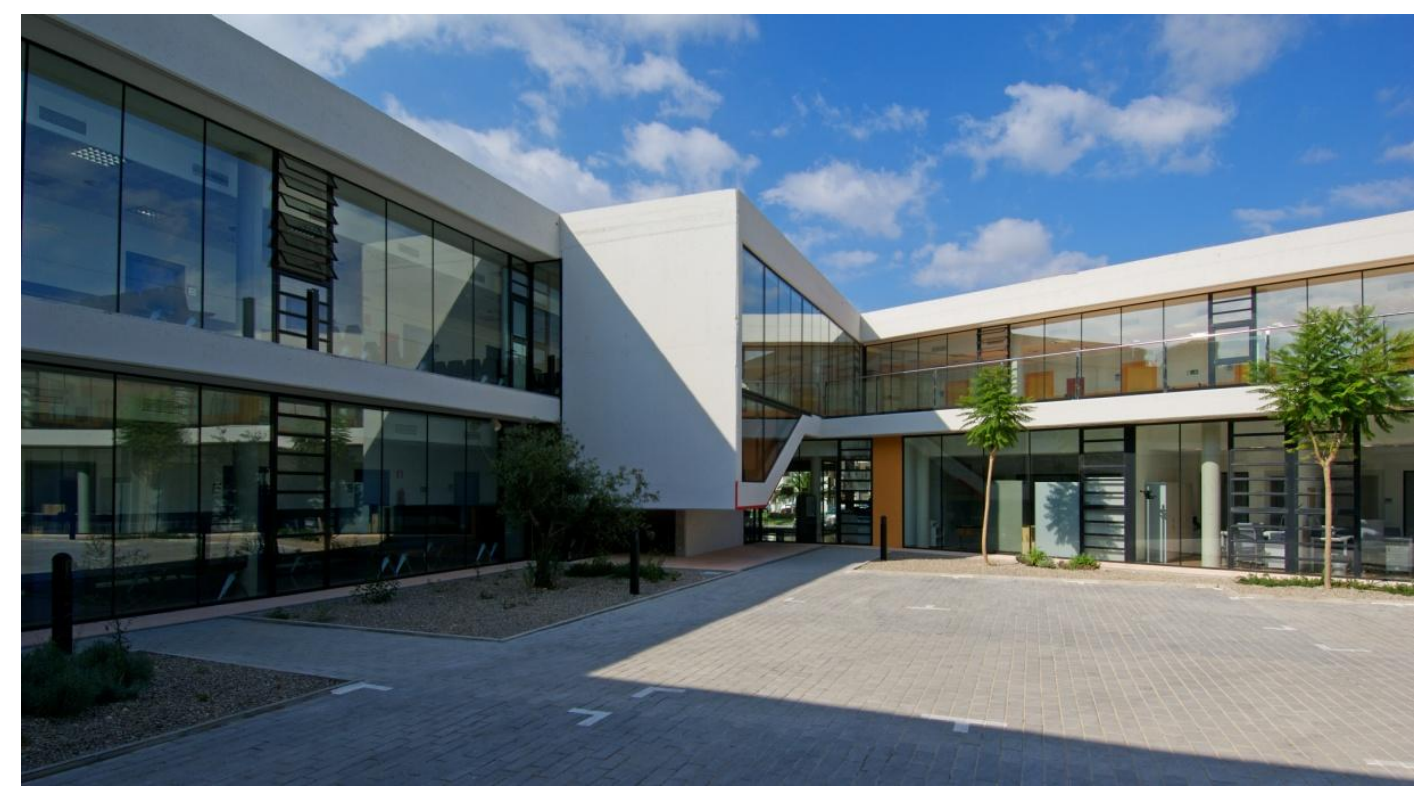

Fig. 106 - Centro de Saúde em Felanitx Fonte: acervo pessoal do arquiteto Caio Faggin

\footnotetext{
“A essência do pátio interno não é simplesmente o contato com a natureza, pois isso já ocorreria através das aberturas do edifício ou mesmo no seu exterior, mas um espaço seguro relacionando-se com a natureza. O pátio interno é a construção de um
} 
lugar protegido e relacional. Este conceito remete à imagem da mãe ao conter o seu filho no aconchego de seus braços, junto ao calor de seu corpo". (REIS-ALVES, 2005) 13

Por ser o elemento condutor de luz para o interior do edifício, o pátio ganha significado e valor neste projeto. $\mathrm{O}$ arquiteto buscou através dele priorizar o bem-estar psicológico dos pacientes, permitindo a integração com o espaço externo, mesmo que a abundância de luz do dia pudesse comprometer aspectos relacionados ao conforto térmico ou luminoso - ofuscamentos e reflexos.

O piso polido dos pavimentos tornou-se uma grande superfície reflexiva da luz do dia que atravessa todo o espaço. Os painéis em vidro se comportam também como espelho, refletindo não apenas a luz como também os volumes que conformam o pátio interno.

A opção pela transparência das áreas de espera permite ver e ser visto. O contato visual direto entre essas áreas possibilita, de alguma maneira, que os usuários compartilhem suas experiências: sejam elas de dor ou de contentamento.

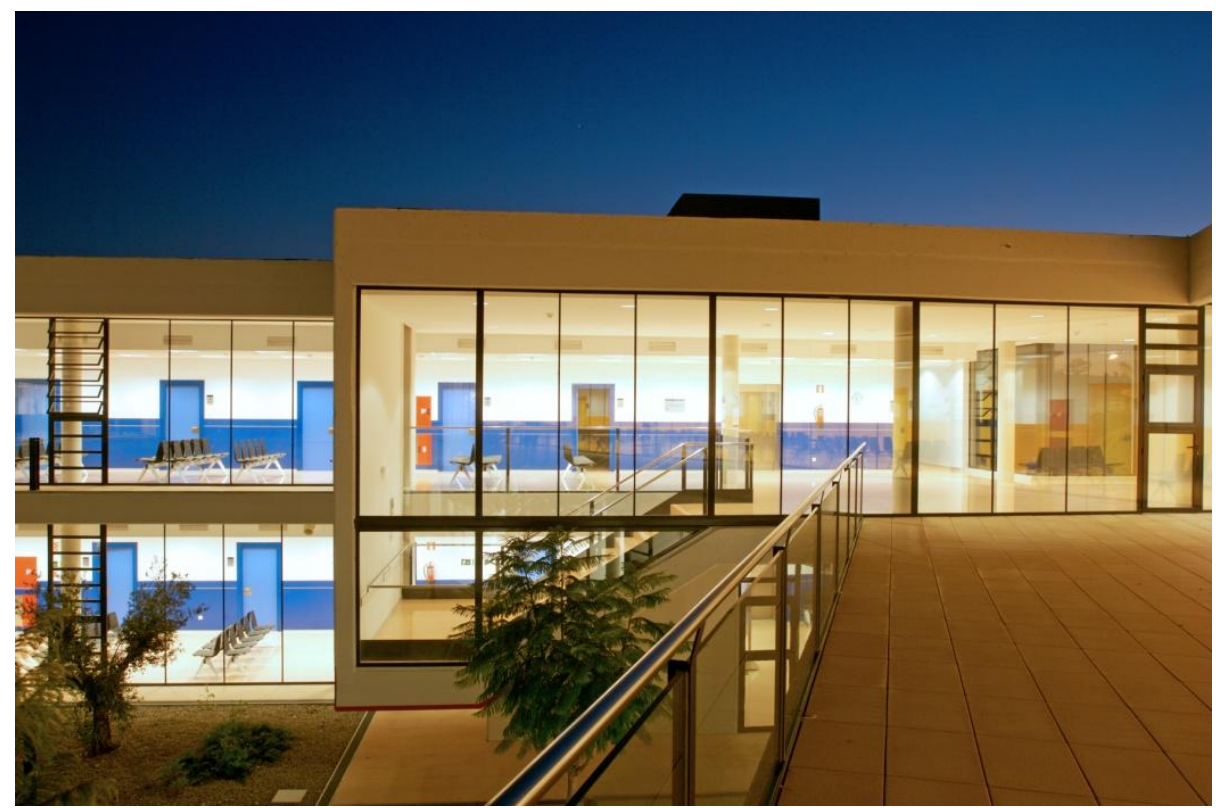

Fig.107 - Centro de Saúde em Felanitx Fonte: acervo pessoal do arquiteto Caio Faggin

\footnotetext{
${ }^{13}$ REIS-ALVES, Luiz Augusto dos, arquiteto e urbanista, mestrado em arquitetura na área de Conforto Ambiental (PROARQ/FAU/UFRJ), doutorando em arquitetura (PROARQ/FAU/UFRJ) e pesquisador da École d'Architecture de Toulouse/Groupe de Recherche Environnement Conception, França.
} 


\subsection{EDIFÍCIO II:}

LOJA E CAFETERIA - COORDENADAS $22^{\circ} 44^{\prime} 11^{\prime \prime} \mathrm{S}, 45^{\circ} 36^{\prime} 38^{\prime \prime} \mathrm{O}$

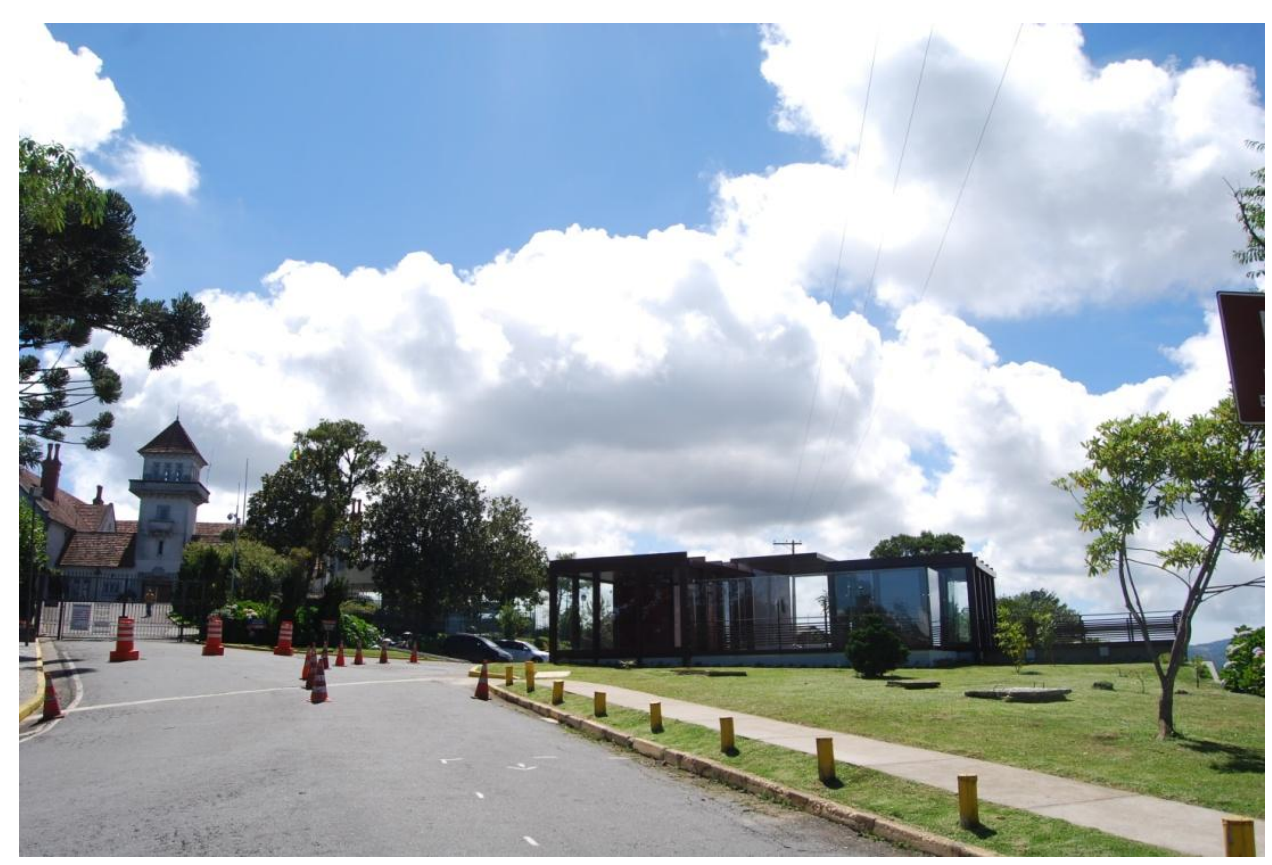

Fig.108 - Loja e Cafeteria em Campos do Jordão Fonte: acervo pessoal do arquiteto Caio Faggin

\subsubsection{Localização}

A loja e cafeteria estão localizadas no Alto da Boa Vista, na cidade de Campos do Jordão, em São Paulo, junto ao Palácio do Governo - Palácio da Boa Vista, com área construída de 145,00m2. O projeto arquitetônico foi elaborado em 2010.

\subsubsection{Breve histórico}

O Palácio da Boa Vista, com projeto arquitetônico do arquiteto polonês Georg Przyrembel, teve a sua construção iniciada em 1938 e a conclusão ocorreu apenas em 1964, tendo a obra ficado parada ao longo desses anos. Inicialmente o edifício seria usado como residência de veraneio do governador do estado de São Paulo. Na década de setenta, o edifício foi transformado em monumento público e centro cultural devido ao seu restrito uso residencial e, desde então, abriga coleções de arte. Em 1989 foi inaugurada a Capela de São Pedro Apóstolo, em anexo ao Palácio, cujo projeto é do arquiteto Paulo Mendes da Rocha. O 
arquiteto recebeu a incumbência de elaborar o projeto do novo edifício de maneira que este não interferisse negativamente na paisagem local. A capela foi construída em concreto armado e fechamentos em vidro e é circundada por espelhos d'água, reunindo obras sacras do período colonial assim como criações contemporâneas.

O Palácio situa-se no alto de uma colina a sua localização permite uma visão panorâmica da região e faz com que ele seja avistado de diversos pontos da cidade.

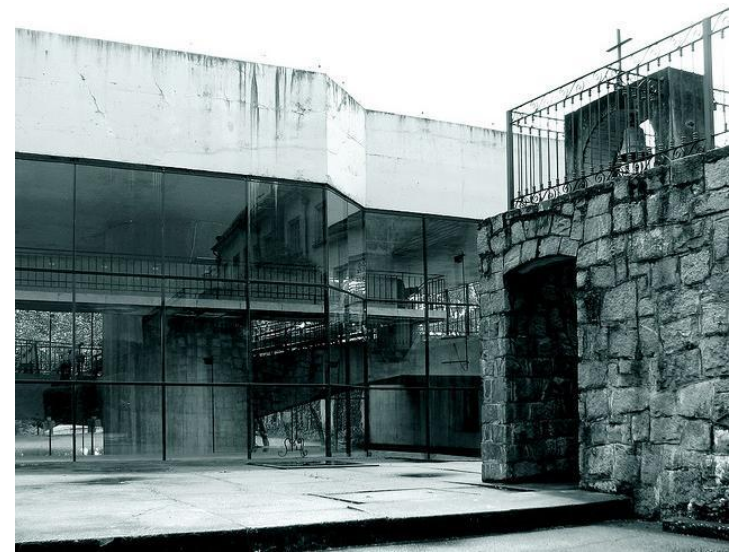

Fig.109 - Capela de São Pedro Apóstolo em Campos do Jordão Fonte: http://www.flickr.com/photos/gaf/3226359240/in/photostream/

\subsubsection{Estudo analítico do edifício: a implantação}

O edifício foi implantado em um platô na encosta que dá acesso ao Palácio da Boa Vista. Uma rampa e uma circulação entre o bloco dos sanitários e a livraria dão acesso ao átrio que é o elemento distribuidor dos fluxos no espaço. Os espaços da loja, da cafeteria e da área externa de estar que integra as duas áreas comerciais são acessados a partir do átrio. 


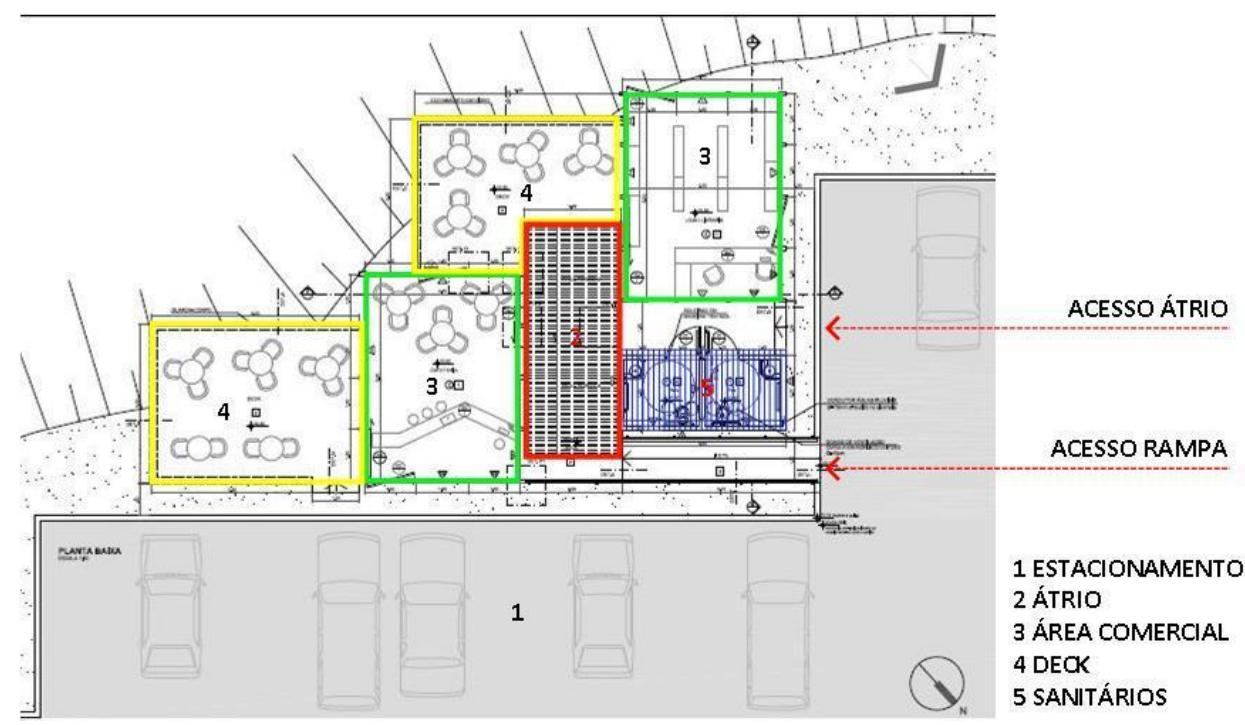

Fig.110 - Implantação Loja e Cafeteria em Campos do Jordão Fonte: acervo pessoal do arquiteto Caio Faggin

A solução formal adotada e a escolha dos materias estabeleceram uma relação direta e transparente do espaço interno com o entorno. Devido à altitude de sua localização, todas as visuais puderam ser preservadas em todos os espaços do conjunto. A configuração do espaço permitiu que o edifício tivesse diferentes orientações, predominantemente nordeste nas faces da cafeteria e da loja e, sudeste e sudoeste nas áreas externas de estar.

\subsubsection{Composição espacial}

O conjunto é formado por três volumes - dois translúcidos que abrigam a área da cafeteria e da loja e outro opaco que abriga os sanitários. Entre os volumes, o arquiteto propôs uma pérgula, apoiada sobre estes, configurando o átrio que distribui os fluxos, interligando e relacionando os volumes.

A preservação das vistas contribuiu para a definição do partido arquitetônico. A preocupação com a transparência do objeto construído foi determinante para o arquiteto, que não queria que o usuário da loja ou da cafeteria deixasse de vislumbrar as vistas ou que os volumes pudessem bloquear a visão da paisagem de quem estivesse fora do edifício. 


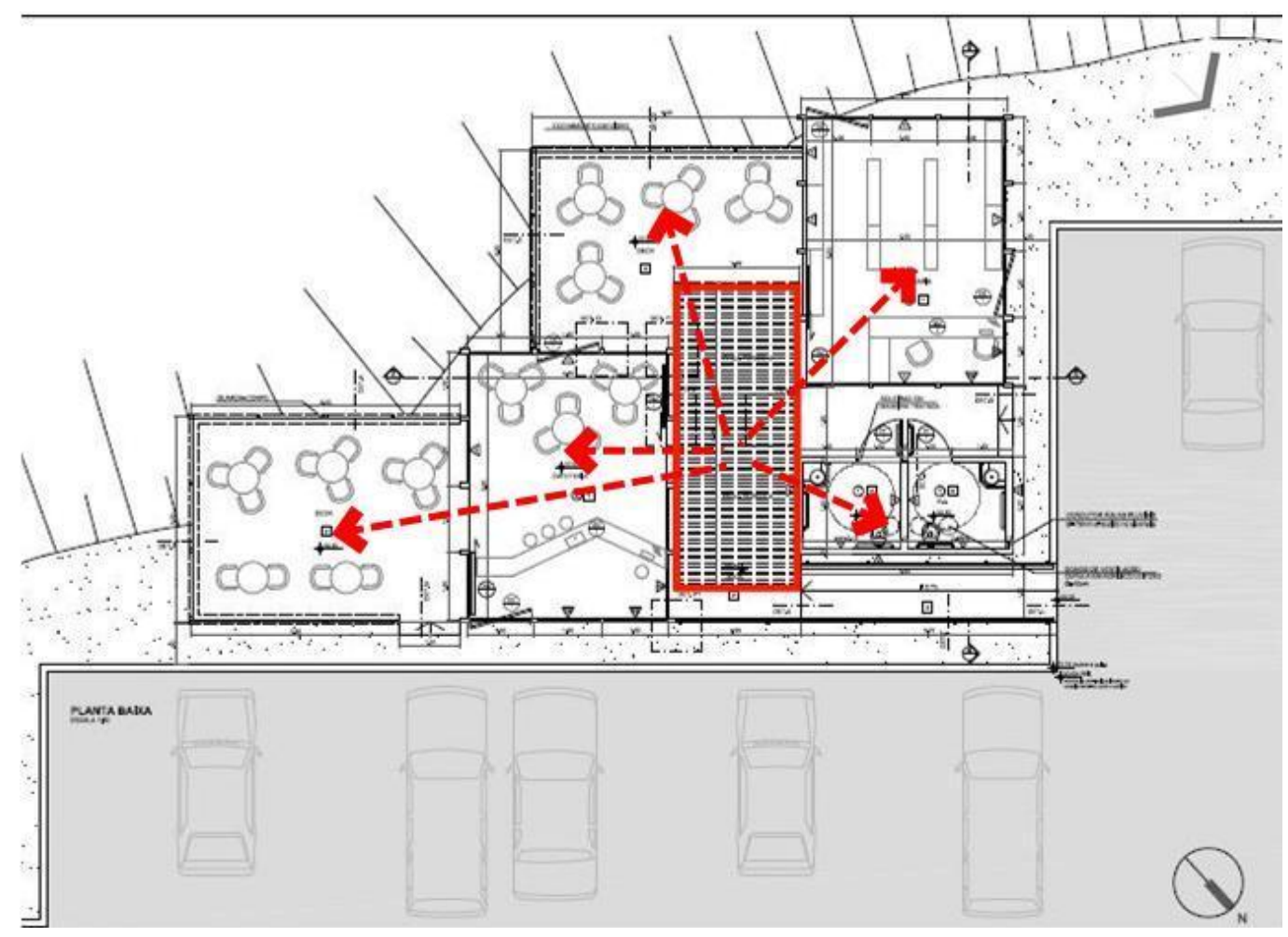

Fig.111 - Distribuição dos fluxos Loja e Cafeteria em Campos do Jordão Fonte: acervo pessoal do arquiteto Caio Faggin

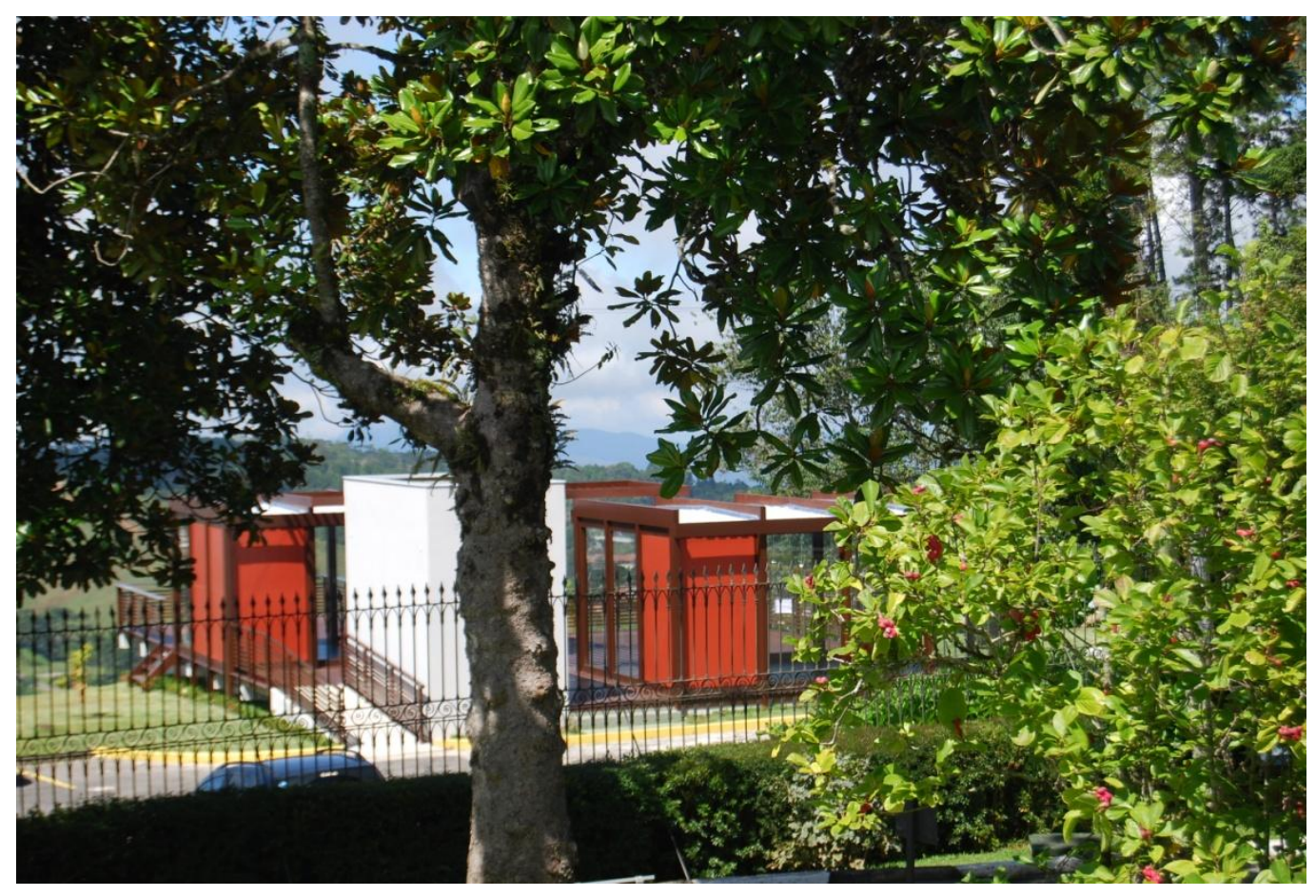

Fig.112 - Loja e Cafeteria em Campos do Jordão Fonte: acervo pessoal do arquiteto Caio Faggin 


\subsubsection{Materiais e cores}

O edifício está assentado sobre vigas de baldrame em concreto que suportam vigas de madeira que compõem o piso do conjunto. Toda a estrutura é em madeira tratada - ipê amarelo com os fechamentos externos em vidro laminado e painéis sanduíche melamínicos na cor cerâmica.

O volume dos sanitários foi executado em blocos de concreto e recebeu pintura na cor branca. A cobertura proposta foi uma laje impermeabilizada.

A estrutura da cobertura dos volumes translúcidos é em madeira e foram utilizadas telhas metálicas sanduíche com forro interno em madeira, contribuindo para o conforto térmico no interior da edificação.

Com exceção dos sanitários onde o revestimento de piso proposto foi o cerâmico, nos demais espaços do edifício foram utilizadas tábuas de madeira como revestimento do piso.

Tanto a cor da madeira da estrutura quanto a dos painéis melamínicos estabelecem um diálogo com a vegetação do entorno e com os telhados da cidade vislumbrados do alto da encosta.

Guarda-corpo em madeira ripada protege a área externa de estar junto à cafeteria e na área externa de estar junto à loja, o guarda-corpo possui, externamente à madeira, painéis de vidro translúcido laminado.

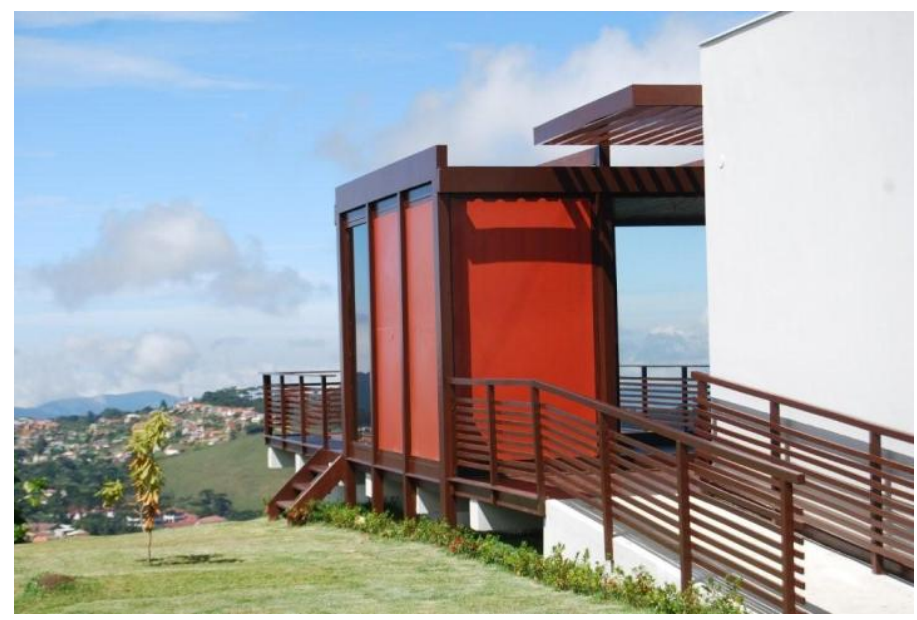

Fig. 113 - Loja e Cafeteria em Campos do Jordão Fonte: acervo pessoal do arquiteto Caio Faggin 

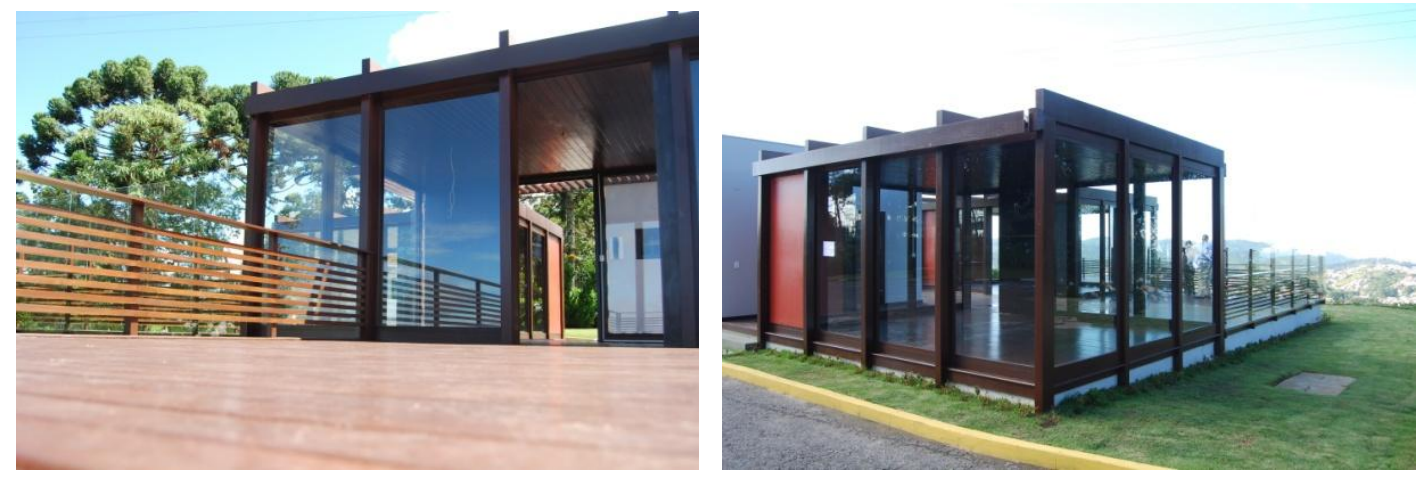

Fig. 114 - Loja e Cafeteria em Campos do Jordão Fonte: acervo pessoal do arquiteto Caio Faggin

\subsubsection{Iluminação natural: aspectos funcionais e subjetivos}

A cidade de Campos do Jordão está localizada na Serra da Mantiqueira, a uma altitude de 1.630 metros acima do nível do mar, e sua temperatura média anual é de $16^{\circ} \mathrm{C}$, segundo o banco de dados do Instituto Nacional de Meteorologia - INMET.

Ao pensar o edifício como uma caixa translúcida, o arquiteto não apenas considerou a preservação das visuais, mas também o clima do local, tentando apropriar a luz do dia e o calor para a edificação. Essa preocupação refere-se também às condições da ventilação natural do edifício.

“É um edifício excessivamente envidraçado. Agora vamos saber, na experiência prática, como vai se comportar, pois é um edifício em Campos do Jordão e tem a questão da temperatura amena. Em princípio, por questões de custos, ele não tem ar condicionado; nos preocupamos em ter uma ventilação natural adequada, mas não sei se pecamos pelo excesso, pois não se tem o controle da iluminação. Ele é uma caixa envidraçada". (FAGGIN, Apêndice digital)

A modulação proposta à estrutura permitiu a existência de uma modulação nos fechamentos dos volumes que comportam a loja e a cafeteria. Esquadrias fixas de madeira com vidro laminado, esquadrias pivotantes de madeira com vidro laminado, portas de correr com quadro em madeira e vidro laminado e painéis sanduíche melamínicos com miolo em lã de rocha fixos fazem o fechamento dos espaços. 

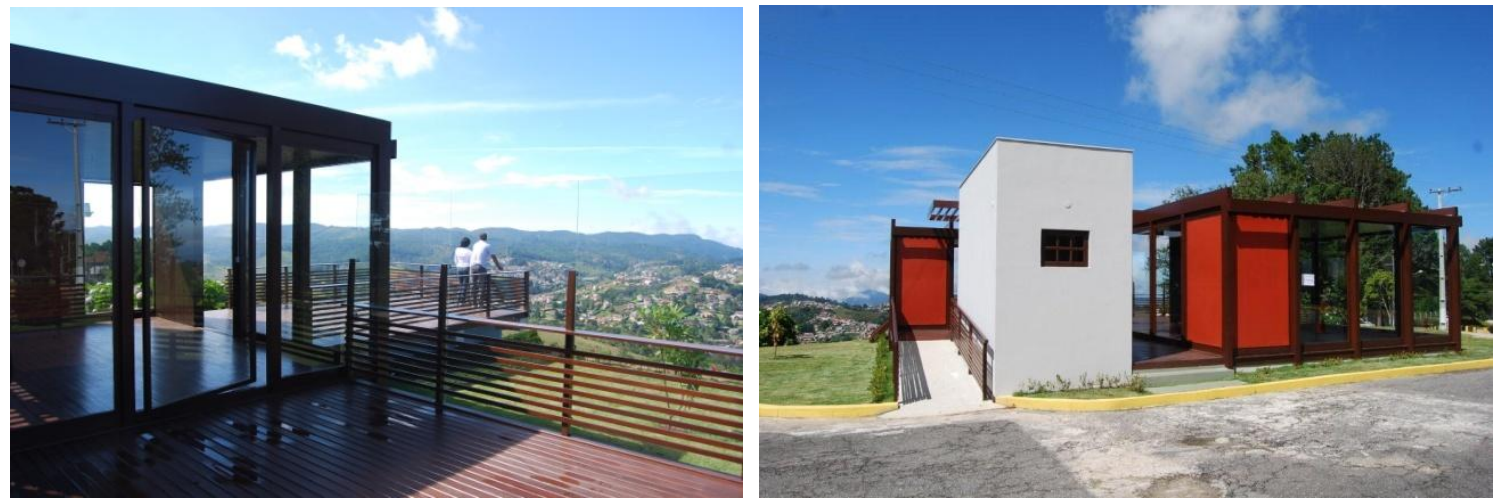

Fig. 115 - Loja e Cafeteria em Campos do Jordão Fonte: acervo pessoal do arquiteto Caio Faggin

Cada sanitário apresenta uma esquadria de madeira maxim’ar com vidro translúcido que não consta em projeto, e essa modificação aconteceu ao longo da obra. Inicialmente a iluminação e ventilação dos sanitários seriam feitas através de dois domus em acrílico leitoso sobre a laje de cobertura.

O piso em madeira permite a reflexão da luz que incide através dos painéis em vidro, podendo gerar ofuscamento em determinados momentos do dia.

As sombras projetadas pelo pergolado e pelos guarda-corpos sobre o piso ripado em madeira estabelecem verdadeiros padrões de desenho que variam ao longo das horas do dia.

Nesse edifício, os espaços opostos, interno e externo, refletem-se na membrana que os envolve, permitindo que estes dois espaços se sobreponham ou se interpenetrem, fazendo com que desapareça qualquer separação entre o interior e o exterior.

Debruçado sobre a paisagem e permeável à entrada da luz do dia, o gesto do arquiteto estabeleceu um diálogo entre o objeto construído e seu entorno, através da transparência de seu invólucro e pelo fato do entorno estar refletido neste invólucro. 
CAPÍTULO VI

\section{A VISÃO DA LUZ DO DIA PARA OS ARQUITETOS DO ESCRITÓRIO PAULISTANO FGMF}

Lourenço Urbano Gimenes, Rodrigo Marcondes Ferraz Silva e Fernando Jaffe de Lima Forte são arquitetos formados pela Faculdade de Arquitetura e Urbanismo da Universidade de São Paulo - FAUUSP, em 2001, 2002 e 2003, respectivamente. Lourenço Gimenes, com Mestrado em 2001, é doutorando por esta mesma instituição. Rodrigo Marcondes Ferraz é mestrando pela FAUUSP e Fernando Forte possui especialização em Sistemas Estruturais. Os dois últimos exercem também atividades acadêmicas, sendo professores de Projeto na Universidade Paulista, UNIP, já Lourenço Gimenes foi professor de Projeto na UNIP, no Istituto Europeo di Design e assistente PAE junto à FAUUSP.

Lourenço Gimenes trabalhou no Architectures Jean Nouvel e Cabinet Alliaume em Paris, com o arquiteto Índio da Costa no Rio de Janeiro e também no escritório BP\&S em Curitiba. Antes mesmo de estarem formados, os três arquitetos fundaram, em 1999, o escritório de arquitetura FGMF. A produção arquitetônica da equipe recebeu relevantes prêmios de arquitetura, tanto nacionais quanto internacionais.

Lourenço Gimenes acredita que a FAU tenha exercido importante papel na formação dos profissionais do escritório ao admitir que ela seja um catalisador das descobertas efetuadas pelos alunos durante o tempo de permanência para a formação. $O$ seu espaço físico, a forma como ela foi concebida, o princípio de sua estrutura, a relação do professor com o aluno, desprovida de hierarquia e a verticalização são os elementos responsáveis por essa percepção da instituição.

\footnotetext{
“É nessa descoberta dessa possibilidade de você usar essa estrutura que está o seu real aprendizado. É cruzando com os alunos, e os professores na rampa é que está o aprendizado". (GIMENES, Apêndice digital)
}

Para explicar o significado da arquitetura, Lourenço Gimenes traça uma analogia entre arquitetura e os idiomas, expondo que cada idioma tem a sua própria forma de construção do pensamento e que não existe uma única maneira de se chegar a uma determinada forma de comunicação. Dependendo da lógica construída por cada profissional 
ao longo da vida, acumulando um repertório de comunicação, têm-se formas diferentes de abordar um problema, resultando em uma multiplicidade de respostas.

\begin{abstract}
“Consideremos que a arquitetura é a materialização no edifício, das aspirações e necessidades de um indivíduo ou coletividade, visando a determinada finalidade, executada dentro das técnicas dominadas por seus executores, com um determinado padrão estético; que a semiologia do espaço, da arquitetura e do espaço arquitetural analisa a "dimensão verbal" do conteúdo da arquitetura, através da identificação de seus análogos verbais, estabelecendo "gramáticas" do espaço urbano ou da arquitetura, analisa as relações entre o espaço mental e o espaço físico, estuda sobre modificação de sentido, semantização e dessemantização do espaço arquitetural localizado, e que analisa o discurso sobre a arquitetura, e não da arquitetura". $(\text { DIAS, 2004) })^{14}$
\end{abstract}

O professor Eduardo de Almeida contribuiu na formação do arquiteto e o ajudou na compreensão de que a construção inexiste. O existente é o efeito da construção que o arquiteto busca.

O aprendizado da iluminação natural em sua formação acadêmica aconteceu de acordo com as ofertas das disciplinas e dentro dos padrões da estrutura curricular do curso: Iluminação Natural, lluminação Artificial e Conforto Térmico. A interface entre a disciplina de Projeto e as disciplinas de Tecnologia e História inexistia durante a sua formação. Na visão do arquiteto, a correlação entre a disciplina de Projeto e as disciplinas teóricas poderia beneficiar os alunos no estúdio. Para ele, na maioria das escolas de arquitetura do país, percebe-se a falta de comunicação entre os departamentos, o que reflete um vício de estrutura e na forma de pensar a transmissão do conhecimento.

O pensamento dos arquitetos sobre a luz do dia na arquitetura parte do princípio de que as aberturas são vistas como possibilidades de fluxo, de visão, de iluminação ou de ventilação. Os vãos assumem outros significados, além da pura necessidade de romper uma parede. Em seus projetos, as características do sítio, do terreno, da iluminação do lugar, da insolação, do entorno, da massa verde existente, da relação dos edifícios, etc. são avaliadas juntamente para a definição do partido. A revisão do programa e a revisão das

\footnotetext{
${ }^{14}$ Artigo apresentado por Solange Irene Smolarek Dias. Bakhtin: signos, polifonia e interpretação do discurso. Semiótica e arquitetura. II ENTEX - Encontro de pesquisa e extensão - UNIOESTE. Cascavel: 2004.
} 
condicionantes fundamentais dão início ao processo projetual. A partir dessa leitura, as hierarquizações de projeto são definidas, diagramas são elaborados e a posterior concepção conjunta.

A preocupação com a abordagem da luz do dia acontece naturalmente durante o processo, assim como a preocupação com os demais elementos que definem o projeto do edifício. Ocorre, conforme cada caso, uma hierarquização dos elementos conformadores do projeto. A luz do dia não é pensada isoladamente e sim como mais um componente do processo. Os seus projetos são muito discursivos no sentido em que a cada solução precede uma intenção, justificada por uma explicação.

Lourenço Gimenes acredita ser necessário um olhar crítico sobre o processo de projeto; que os próprios parâmetros devam ser questionados e criticados a fim de validar ou não um partido arquitetônico.

Para o estudo do comportamento da luz no edifício, nas diferentes horas do dia, os arquitetos utilizam as modelagens em 3D. As maquetes físicas são utilizadas apenas para a compreensão da volumetria do edifício.

As referências de trabalhos desenvolvidos por outros profissionais servem como referências objetivas e não de partido. O trabalho do arquiteto Peter Zumthor é citado pelo profissional como um referencial no exercício da luz do dia enquanto elemento de composição em projeto.

“O cheio é um pedágio para se ter um vazio. O que importa para a gente é o vazio. $\mathrm{E}$ o vazio é luz. O que está no vazio é luz. É o que ressalta num determinado sentido". (GIMENES, Apêndice digital) 


\subsection{EDIFÍCIO I:}

RESIDÊNCIA - COORDENADAS $23^{\circ} 34^{\prime} 47^{\prime \prime} S, 46^{\circ} 40^{\prime} 44^{\prime \prime} O$

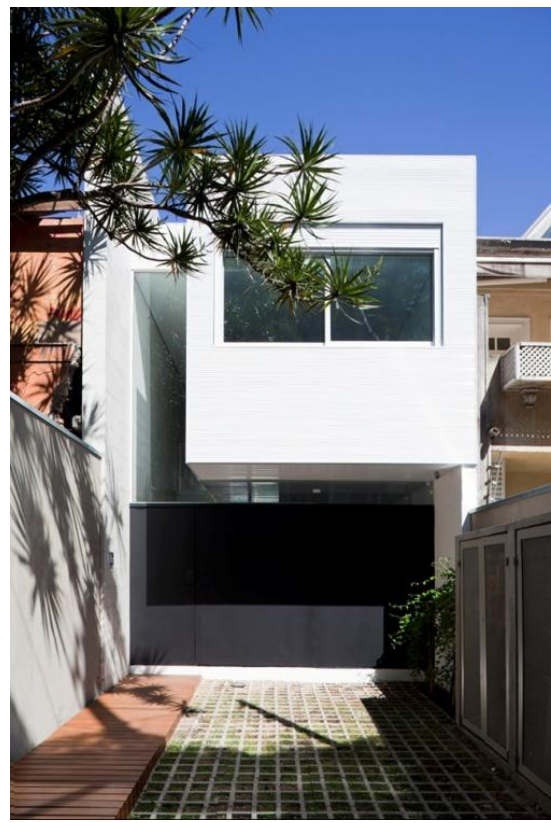

Fig.116 - Residência no Jardim América, São Paulo Fonte: acervo pessoal do arquiteto

\subsubsection{Localização}

A residência está localizada no bairro Jardim América, em São Paulo, em um terreno com área de 120,00m2, com área construída de 150,00m2. O projeto arquitetônico foi realizado em 2008, e a obra concluída no ano de 2011.

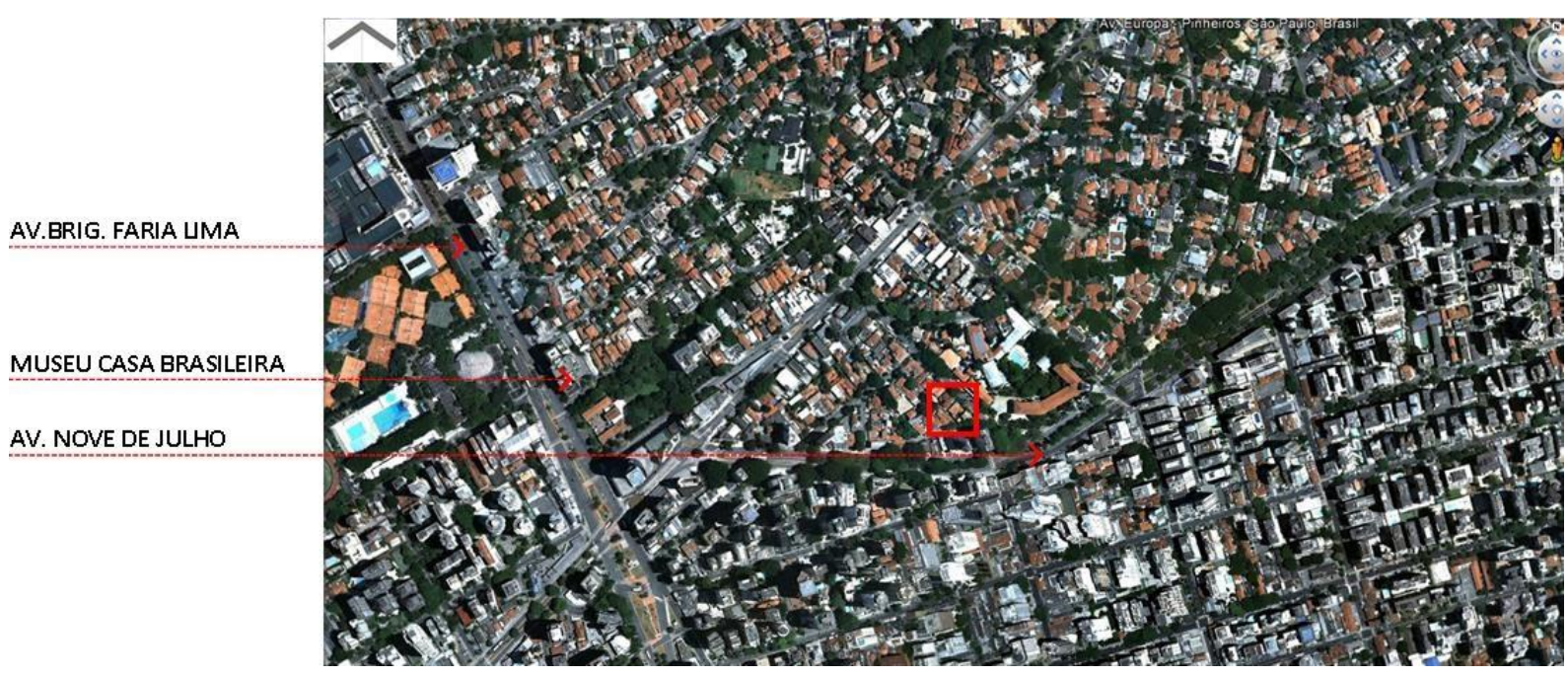

Fig.117 - Situação Residência no Jardim América, São Paulo Fonte: Google Earth 


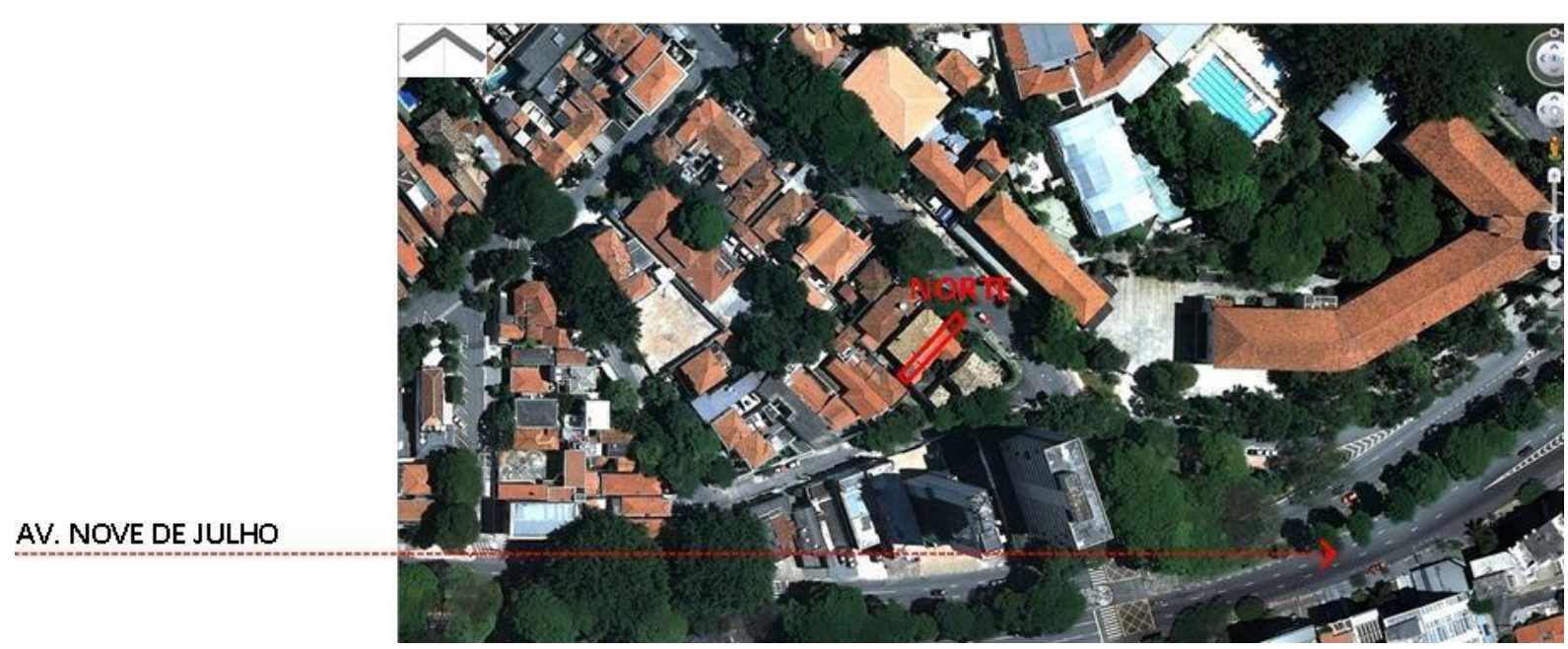

Fig.118 - Situação Residência no Jardim América, São Paulo Fonte: Google Earth

\subsubsection{Equipe técnica}

Projeto de Arquitetura: Clara Reynaldo e Lourenço Gimenes

Colaboradores: Fernando Forte, Rodrigo Marcondes Ferraz, Bruno Araújo, Marcela Aleotti, Marília Caetano, Mirela Caetano, Rafaela Arantes e Wilson Barcellone

Estrutura: INNER Engenharia

Instalações: Ramoska \& Castellani

Paisagismo: Stúdio llex

Painel artístico: Fabio Flaks

\subsubsection{Breve histórico}

Os proprietários, ambos arquitetos, que antes moravam em um apartamento no bairro de Higienópolis, foram assaltados e optaram por procurar outro lugar para morar. $\mathrm{Na}$ busca pelo novo imóvel, encontraram uma pequena casa em estado precário de conservação. Para a aprovação do projeto na Prefeitura de São Paulo, o perímetro existente da residência deveria ser mantido, pelo tombamento do bairro. 


\subsubsection{Estudo analítico do edifício: a implantação}

Devido à exígua testada do lote de apenas quatro metros e às exigências legais, a edificação foi implantada no perímetro existente da anterior residência, encostada nas divisas laterais.

A solução formal adotada pelos arquitetos estabeleceu um jardim interno que integra os dois volumes da edificação, estabelecendo uma relação direta e transparente entre espaço externo do jardim com o espaço interno.

O acesso à edificação ocorre junto à cozinha, posicionada na entrada da edificação.

A edificação está orientada no sentido nordeste/sudoeste permitindo, apesar da exiguidade de sua testada, que todos os seus cômodos recebam a incidência direta da luz solar.
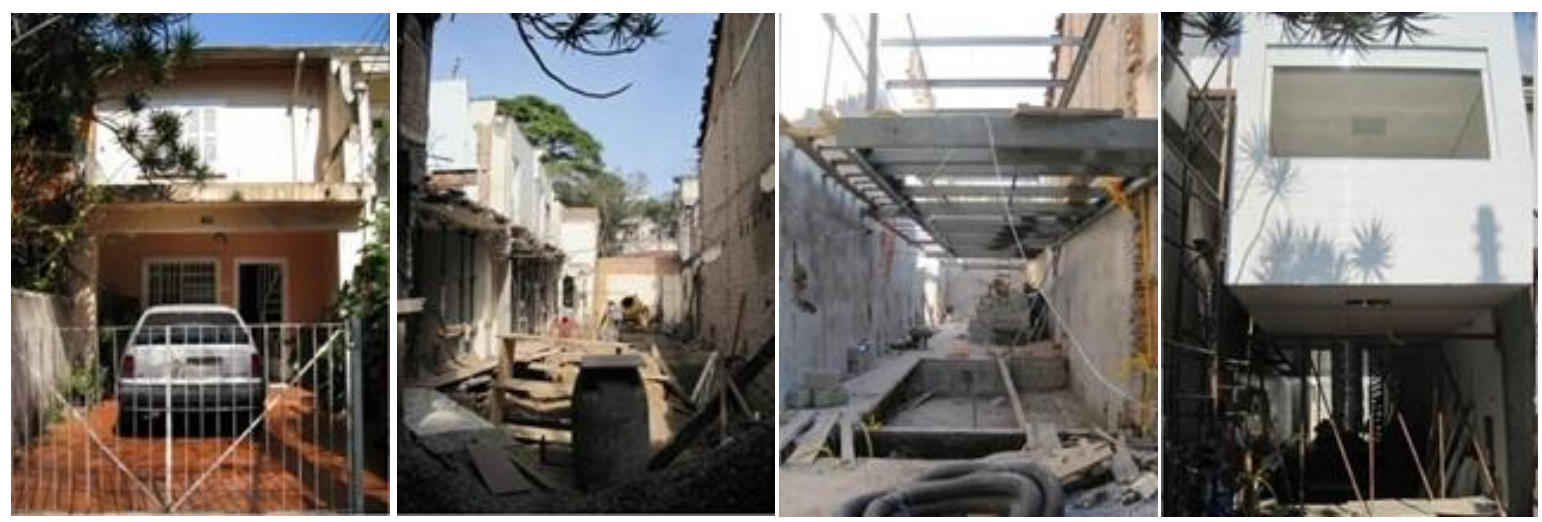

Fig.119 - Residência no Jardim América, São Paulo Fonte: acervo pessoal do arquiteto

\subsubsection{Composição espacial}

Dois planos paralelos e longitudinais ao terreno conformam o paralelogramo que abriga um programa sintético. O edifício é composto por dois volumes interligados por um jardim. O volume frontal abriga o espaço comum da cozinha, refeições e da sala no térreo; e os quartos e banheiros privativos no pavimento superior. No pavimento superior, o volume foi deslocado para marcar o acesso e romper com a unidade da fachada. O volume aos fundos do lote abriga a circulação vertical e a área de serviços no térreo, um escritório no pavimento superior e uma sala na cobertura. 
A empena na face sudeste estabelece toda a circulação horizontal da residência. Uma plataforma metálica conecta o escritório com a área dos quartos no pavimento superior.

A cozinha e refeições localizadas junto ao acesso ao edifício encontram-se a setenta e cinco centímetros abaixo do nível do térreo, fazendo com que o piso no nível da sala abrigue os armários da cozinha sob ele.

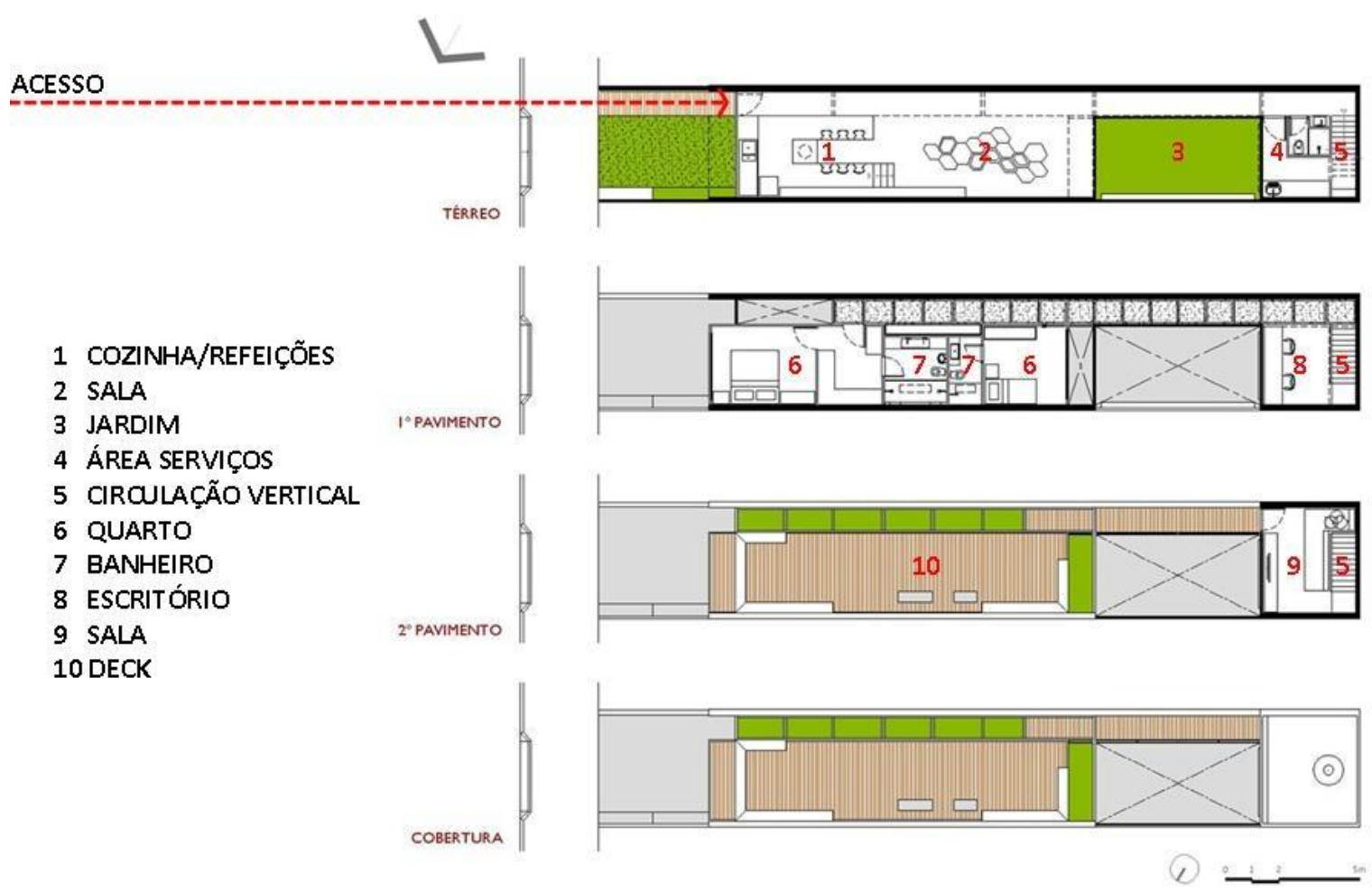

Fig.120 - Plantas Residência no Jardim América, São Paulo Fonte: acervo pessoal do arquiteto 


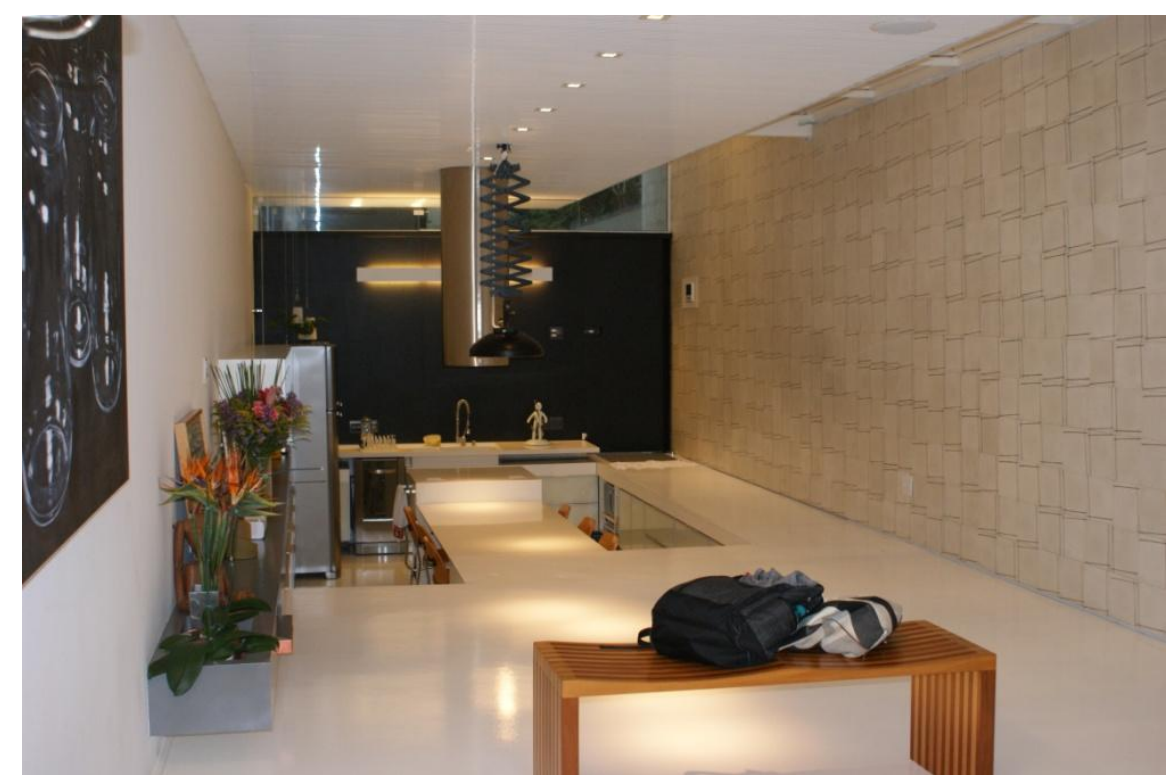

Fig.121 - Residência no Jardim América, São Paulo Fonte: acervo pessoal da autora

\subsubsection{Materiais e cores}

A edificação foi toda concebida e executada por sistemas construtivos leves. A estrutura é metálica, a laje em painel wall e as paredes em gesso acartonado.

O painel que compõe a fachada frontal da edificação é em madeira compensada naval com pintura na cor preto. A área de serviços no térreo tem seu fechamento em vidro para o jardim e, internamente, as paredes são em gesso acartonado.

A fachada sudeste foi revestida internamente com um painel de ladrilhos desenhado pelo artista plástico Fábio Flaks. O prolongamento desse painel para fora da edificação faz com que a obra de arte faça parte da cidade.

O volume que abriga os quartos está atirantado à estrutura metálica. Neste pavimento, o fechamento dos quartos é em painel wall com revestimento externo em lambril de alumínio na cor branca e nos espaços internos o painel recebeu pintura na cor branca. A interligação entre o volume dos quartos com o escritório e a circulação vertical é feita através de passarela metálica em malha expandida.

A cobertura inclinada é metálica, atirantada na estrutura metálica do edifício. $O$ deck flutuante existente está posicionado sobre uma tela metálica sanduíche, atirantada na estrutura metálica. O deck é responsável pelo sombreamento da cobertura, colaborando para o isolamento acústico interno. 
O jardim interno abriga uma parede verde composta por blocos cerâmicos impermeabilizados.

A cor predominante no revestimento das paredes, piso e teto da edificação é o branco.

\subsubsection{Iluminação natural: aspectos funcionais e subjetivos}

O jardim interno funciona como fonte de luz, como paisagem, como polo focal e estratégia térmica para o edifício. A intenção dos arquitetos em estabelecer uma conexão direta das áreas de maior permanência com o jardim possibilitou que os espaços, com exceção do quarto do casal que está voltado para a rua, recebessem iluminação natural.

Os espaços destinados à área de serviços, escritório e sala na cobertura, por estarem orientados a nordeste, receberam um brise metálico em tela expandida, que além de proteger contra a incidência direta da luz do dia também funciona como um guarda-corpo.

A passarela metálica que une os volumes, por sua malha expandida, permite a passagem da luz do dia e a visão do jardim. Os painéis deslizantes de fechamento do jardim, tanto no térreo quanto no pavimento superior são em vidro laminado translúcido.

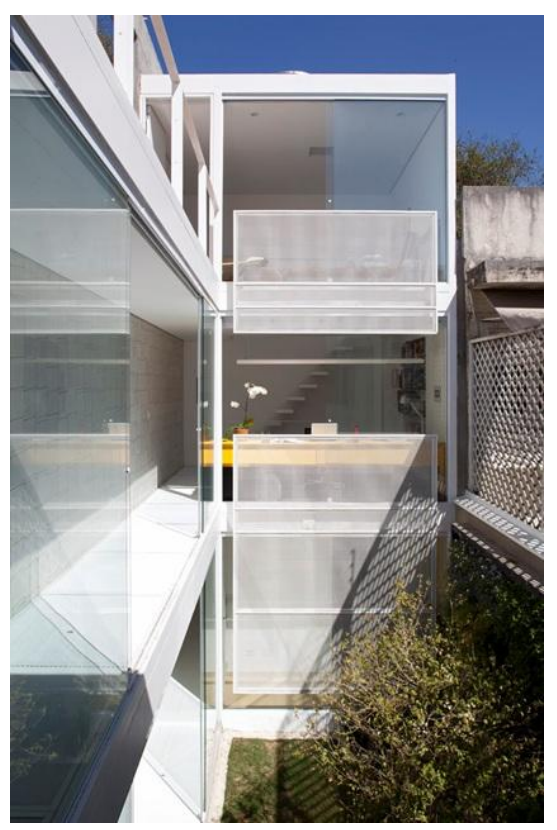

Fig.122 - Residência no Jardim América, São Paulo Paulo

Fonte: acervo pessoal do arquiteto

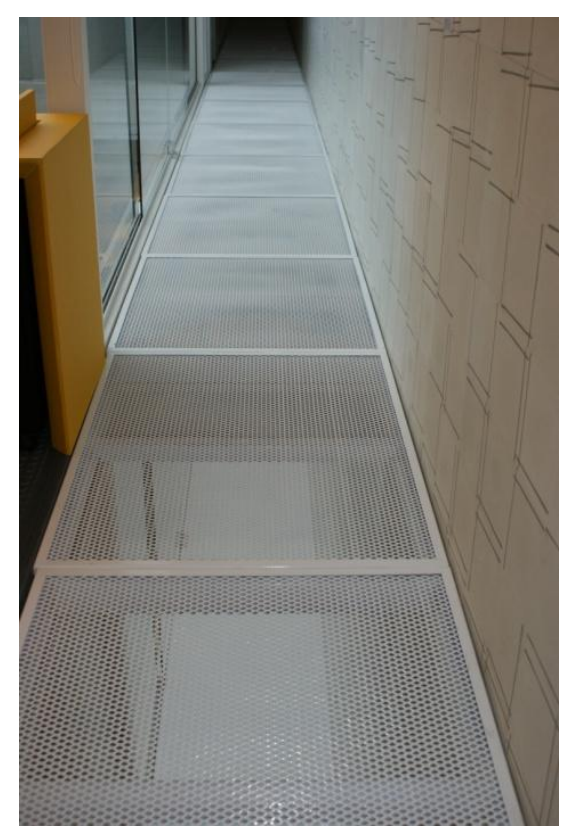

Fig123 - Residência no Jardim América, São

Fonte: acervo pessoal da autora 
Uma tela de proteção solar acionada manualmente protege o quarto voltado para o jardim, da incidência direta da luz do dia durante os meses de verão.

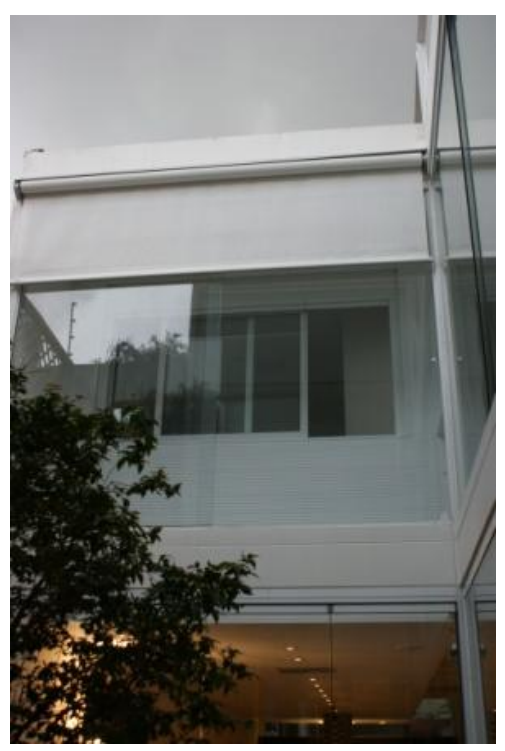

Fig.124 - Residência no Jardim América, São Paulo Fonte: acervo pessoal da autora

Os banheiros são iluminados através de aberturas zenitais em vidro laminado translúcido.

Pelo fato de ter poucas fachadas, a estratégia da escolha dos materiais, por possuírem alto índice de reflexão, possibilitou que a luz do dia ao atingir uma superfície fosse refletida por ela em outra superfície e assim sucessivamente. Reflexões múltiplas.

Quem olha da rua o imóvel tão estreito, não imagina que a luz do dia possa estar presente e de maneira tão abundante na residência. É surpreendente quando se entra no edifício e se percebe que o gesto dos arquitetos permitiu que a luz do dia fosse uma constante do espaço interno.

A casa, essencialmente branca, rende-se à luz do dia, permitindo seu livre acesso através de poucos elementos e de desejáveis reflexões. Apesar de referências estrangeiras das pequenas casas japonesas, os arquitetos utilizaram uma linguagem própria que tirou proveito do clima da cidade e privilegiou a iluminação natural. 


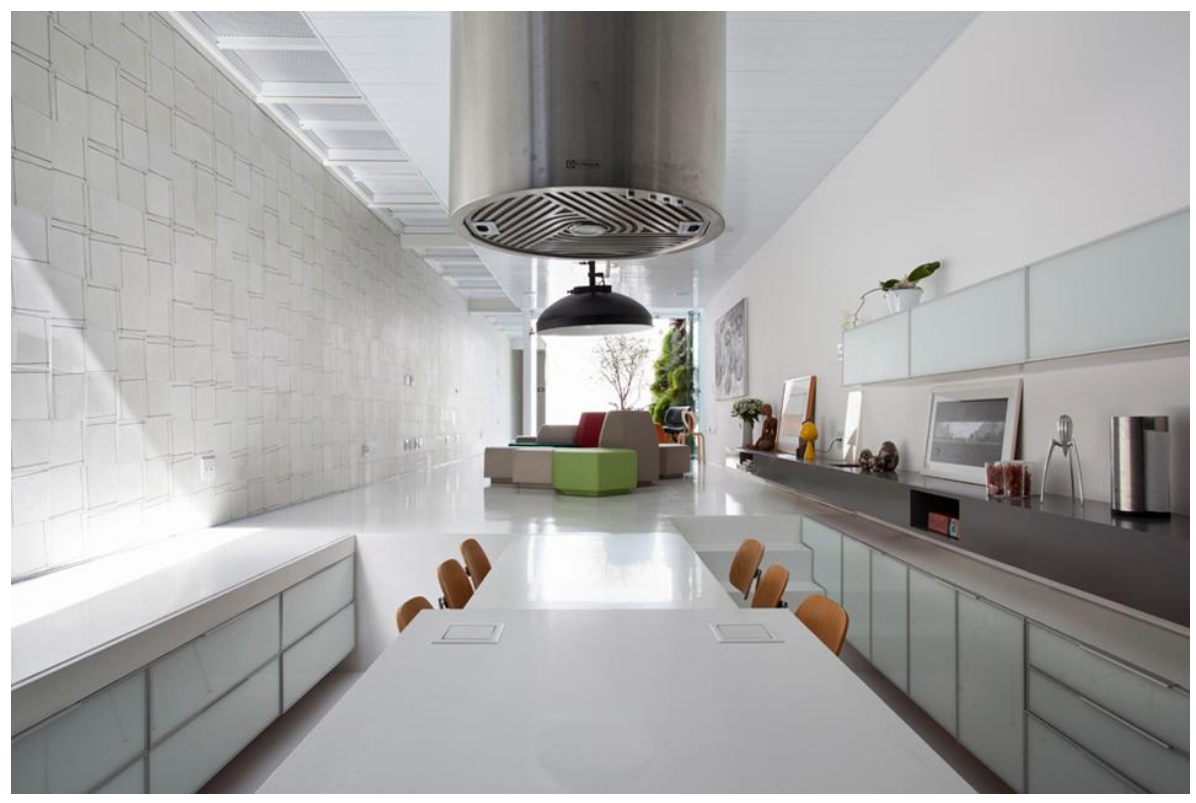

Fig.125 - Residência no Jardim América, São Paulo Fonte: acervo pessoal do arquiteto 


\subsection{EDIFÍCIO II:}

EDIFÍCIO COMERCIAL - COORDENADAS $23^{\circ} 33^{\prime} 49^{\prime \prime}$, 46 46 $38^{\prime} 54^{\prime \prime} \mathrm{O}$

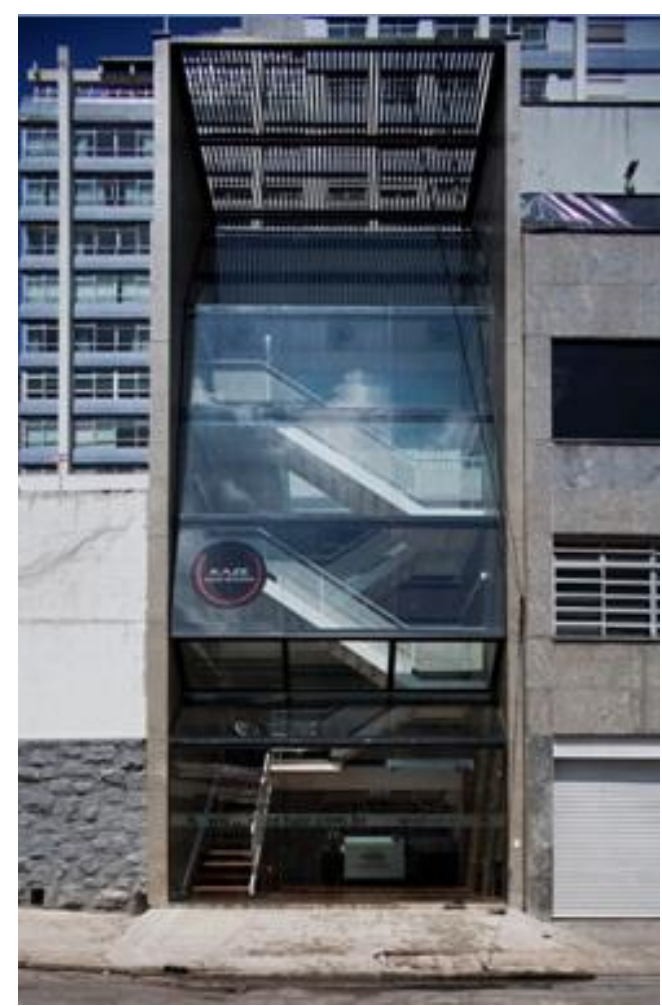

Fig.126 - Edifício Comercial, São Paulo Fonte: acervo pessoal do arquiteto

6.2.1. Localização

O edifício comercial ocupado por um salão de cabeleireiros está localizado no bairro Belo Vista, em São Paulo, em um terreno com área de 120,00m2, com área construída de 335,00m2. O projeto arquitetônico foi realizado em 2008, e a conclusão da obra em 2009. 


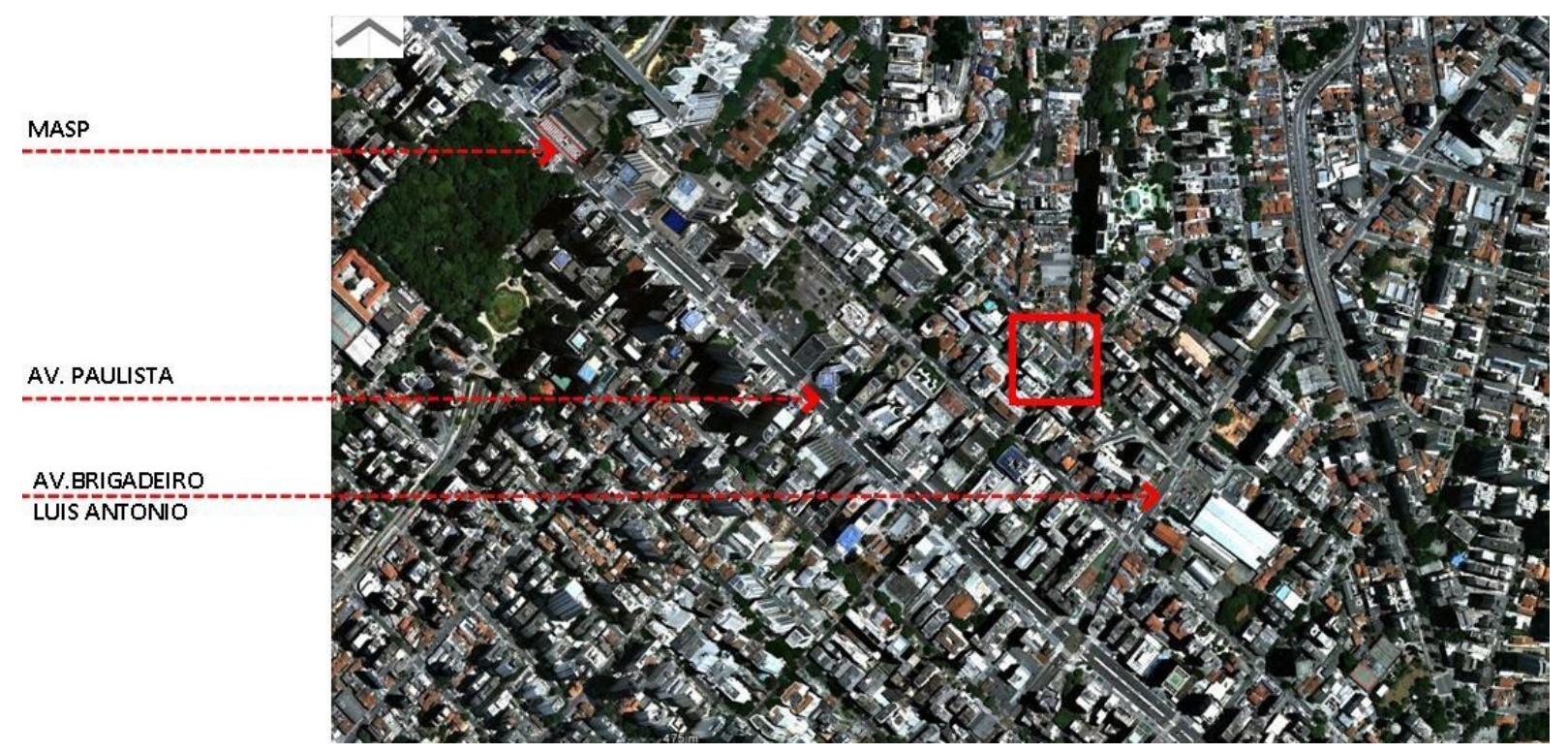

Fig.127 - Situação Edifício Comercial, São Paulo Fonte: Google Earth

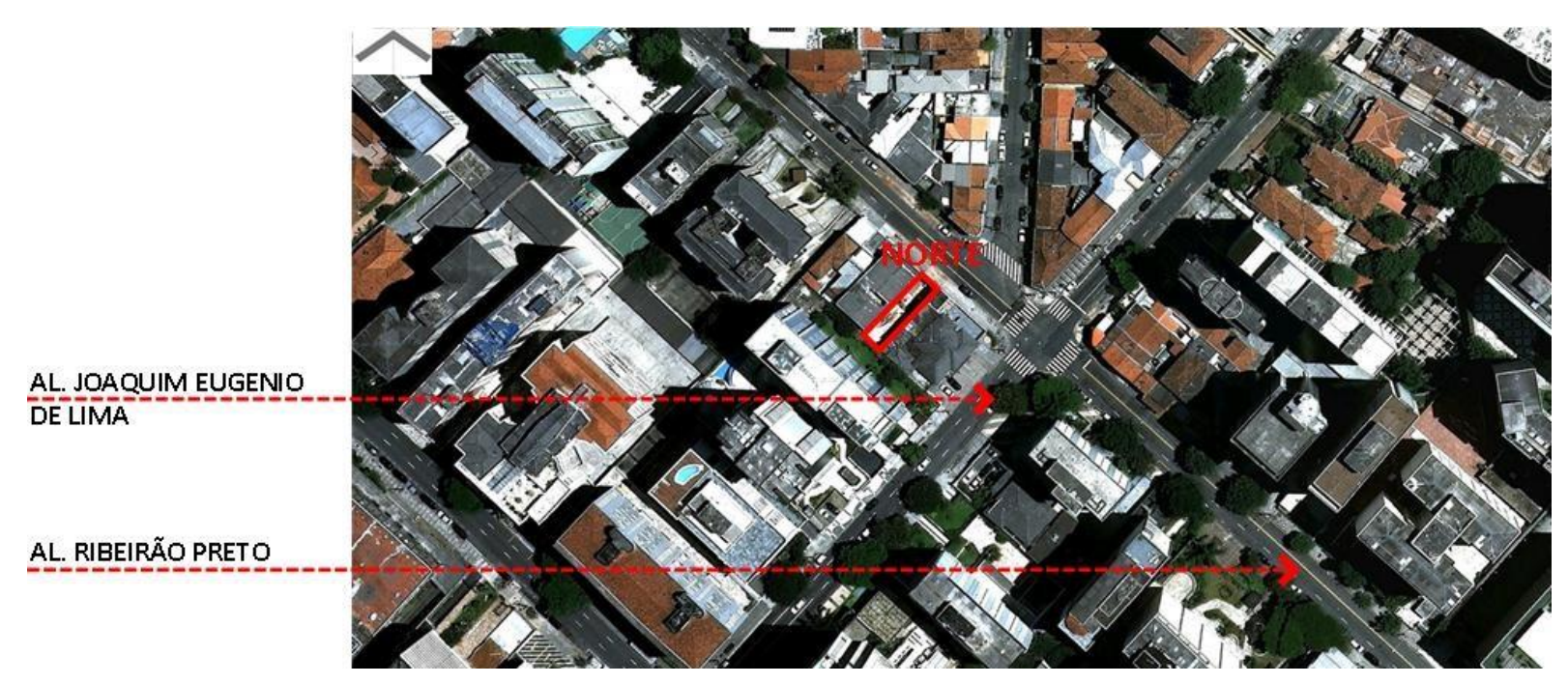

Fig.128 - Situação Edifício Comercial, São Paulo Fonte: Google Earth

\subsubsection{Equipe técnica}

Projeto de Arquitetura: Fernando Forte, Lourenço Gimenes e Rodrigo Marcondes Ferraz

Coordenadores: Dante Furlan e Renata Davi

Arquiteta: Mônica Harumi Yosioka

Estrutura: Oppea

Instalações: Ramoska \& Castellani

Construção: Sema

Painel artístico: Fabio Flaks 


\subsubsection{Breve histórico}

O proprietário do salão de cabeleireiros possuía uma rede de salões de cabeleireiros cujas unidades estavam instaladas dentro de shopping centers. Em 2004 o proprietário decidiu criar unidades físicas na rua, quando contratou o escritório FGMF para elaborar o projeto arquitetônico da unidade piloto, que foi construída no bairro da Mooca. Em 2008 surgiu uma nova solicitação ao escritório, para o desenvolvimento de uma unidade no bairro Bela Vista em São Paulo. O forte argumento do proprietário para a instalação de unidades de rua era a necessidade da iluminação natural nos espaços, fator estratégico para a escolha das tinturas de cabelo.

No terreno onde foi implantado o salão havia uma obra abandonada e os arquitetos solicitaram à Prefeitura de São Paulo a liberação para um projeto modificativo a fim de manter os recuos existentes, estabelecidos há muitos anos.

\subsubsection{Estudo analítico do edifício: a implantação}

Devido à pequena testada do lote e a pré-existência das empenas laterais, a implantação do edifício acompanha as proporções do lote, caracterizado pelo aclive natural que foi incorporado ao projeto através do uso restrito do pavimento térreo.

Os espaços estão organizados em quatro pavimentos e o acesso ao edifício ocorre junto ao átrio frontal, com pé direito quádruplo, onde está localizada a circulação vertical.

O edifício orientado a nordeste recebe em sua fachada assimétrica a incidência direta da luz do dia ao longo de todos os meses do ano.

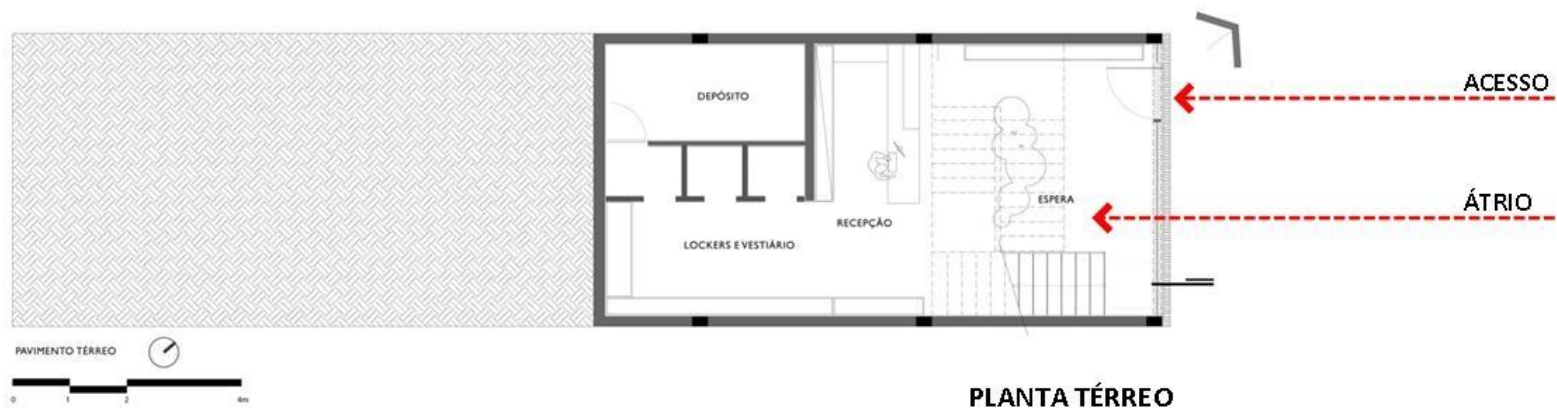

Fig.129 - Planta térreo Edifício Comercial, São Paulo Fonte: acervo pessoal do arquiteto 
Dois planos paralelos e longitudinais ao terreno conformam o paralelogramo que abrigam os diversos espaços, articulados por uma escada metálica localizada no átrio que define o principal eixo do edifício

No térreo estão localizadas a área de recepção e trocadores. No primeiro e segundo pavimentos estão dispostas as áreas de corte, lavagem, tinturas, banheiros e copa e no terceiro pavimento a área administrativa e o terraço.

Um jardim interno foi criado a partir do primeiro pavimento, a fim de cumprir a principal solicitação do cliente: a máxima apropriação da luz do dia ao edifício. Este jardim interno abriga um painel vertical produzido pelo artista plástico Fábio Flaks.

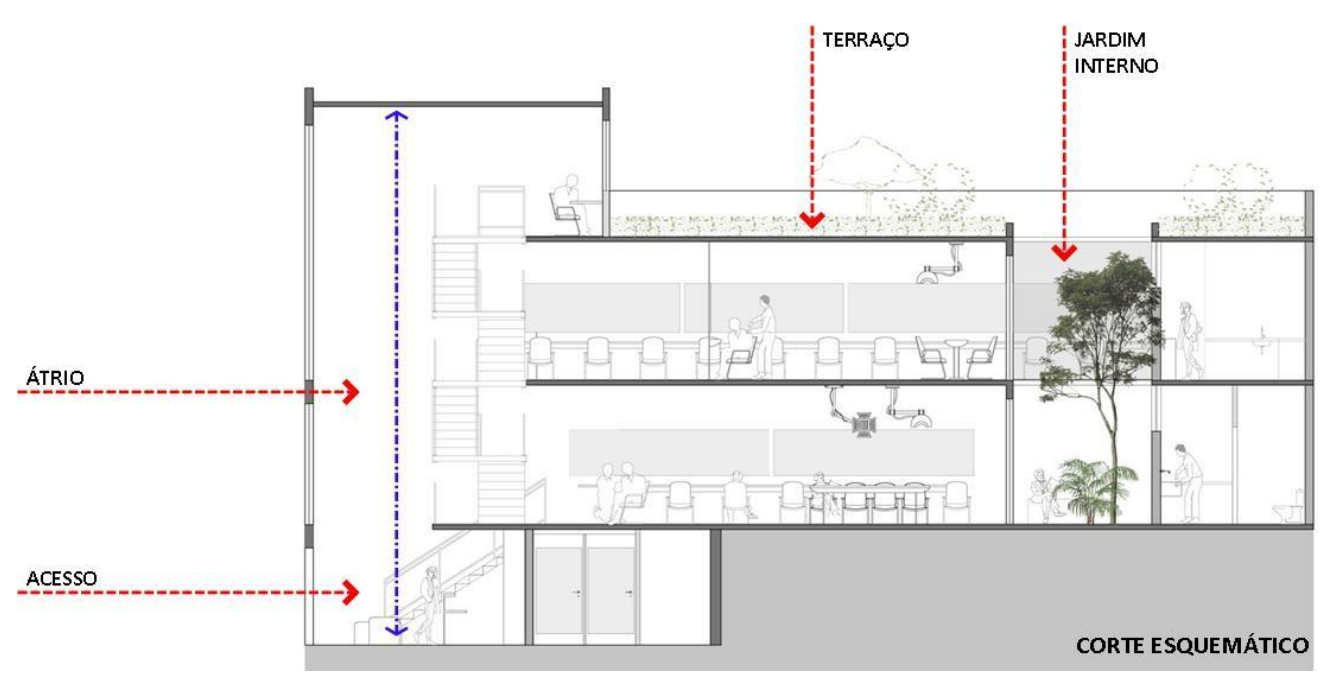

Fig.130 - Corte esquemático Edifício Comercial, São Paulo Fonte: acervo pessoal do arquiteto
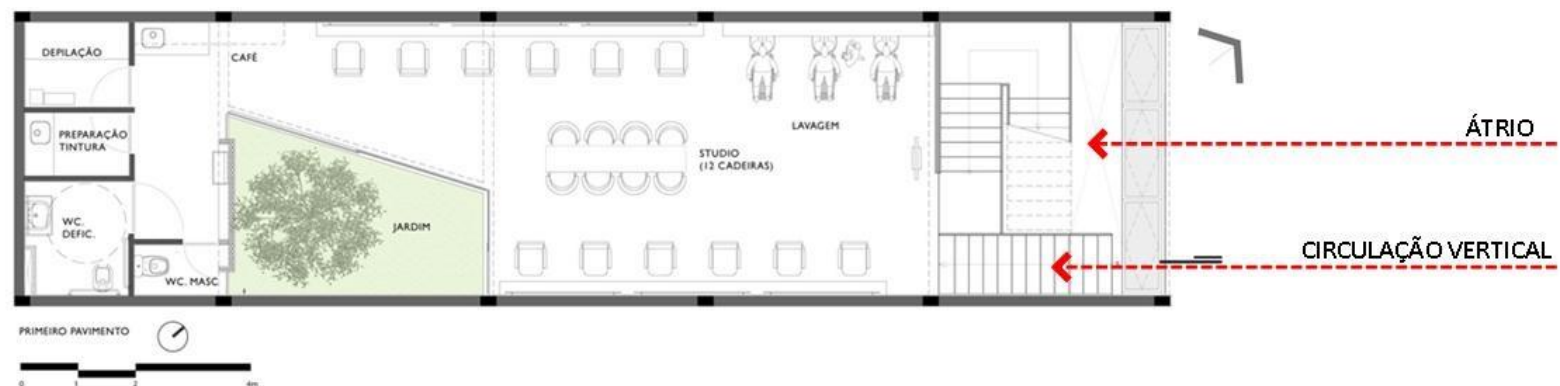

PLANTA PRIMEIRO PAVIMENTO

Fig.131 - Planta primeiro pavimento Edifício Comercial, São Paulo Fonte: acervo pessoal do arquiteto 


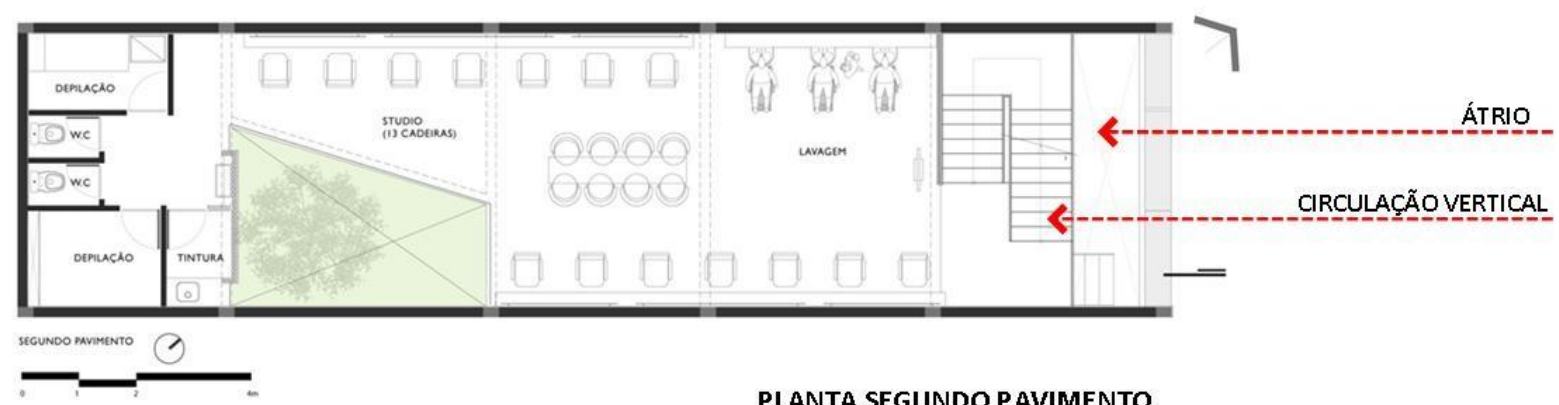

Fig.132 - Planta segundo pavimento Edifício Comercial, São Paulo Fonte: acervo pessoal do arquiteto

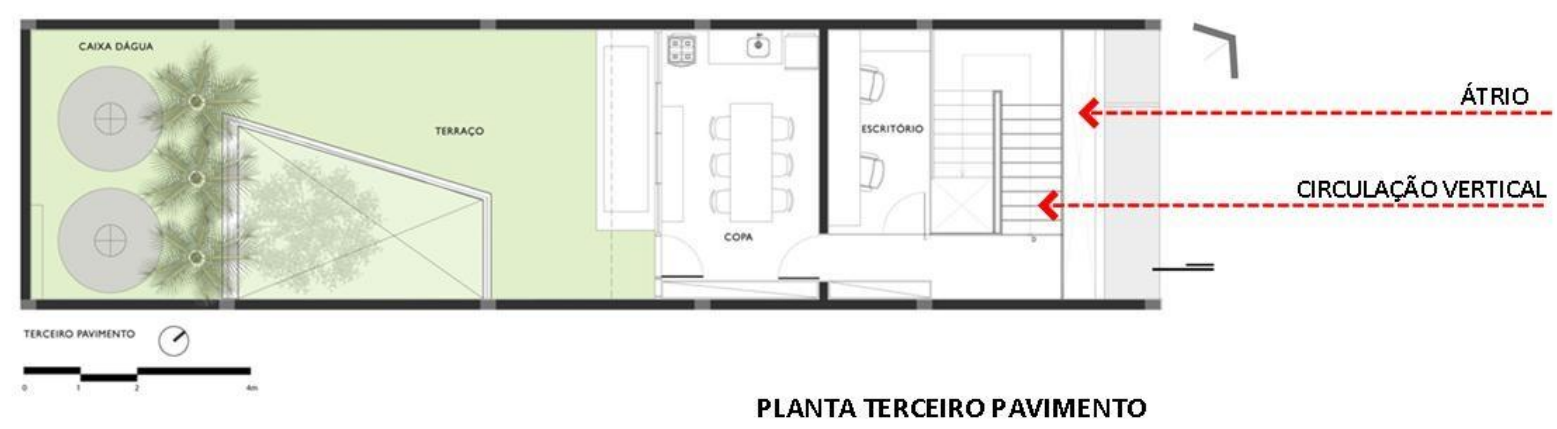

Fig.133 - Planta terceiro pavimento Edifício Comercial, São Paulo Fonte: acervo pessoal do arquiteto

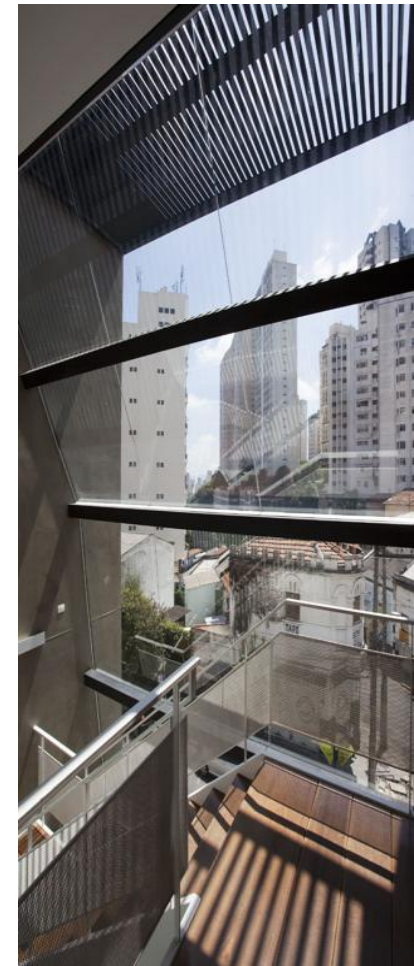

Fig.134 - Edifício Comercial, São Paulo Fonte: acervo pessoal do arquiteto

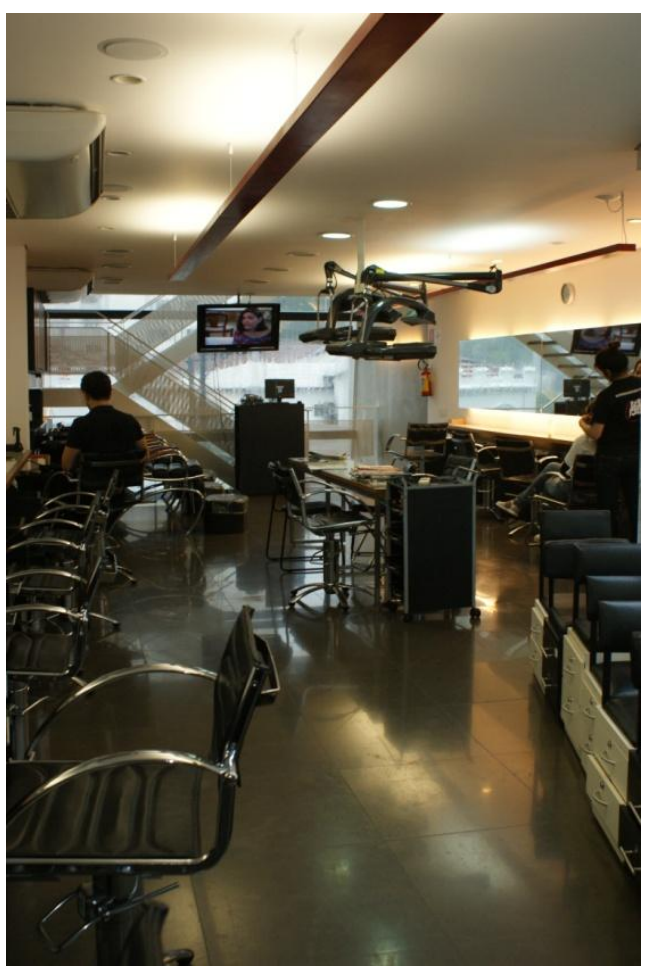

Fig.135 - Edifício Comercial, São Paulo Fonte: acervo pessoal da autora 


\subsubsection{Iluminação natural: aspectos funcionais e subjetivos}

A proposta dos arquitetos prevê que a pele assimétrica de vidro translúcido que compõe a fachada permita a incidência direta da luz do dia e também a entrada de ar. A fachada de vidro deixou de representar um problema quanto à insolação e aquecimento excessivo com a utilização do átrio como uma grande chaminé térmica.

A pele de vidro que faz o fechamento da fachada foi facetada com diferentes inclinações a fim de que a incidência da luz não ocorresse de maneira tão direta. As trocas de ar frio e quente no interior do edifício acontecem através de aberturas inclinadas da fachada, posicionadas no primeiro pavimento e através de três exaustores mecânicos posicionados na cobertura. Uma grelha metálica na cobertura, apoiada nas empenas laterais, proposta como um brise horizontal filtra os raios solares incidentes no verão. 0 jardim interno fechado com portas de vidro deslizantes contribui para a entrada da luz do dia como também favorece a circulação do ar.

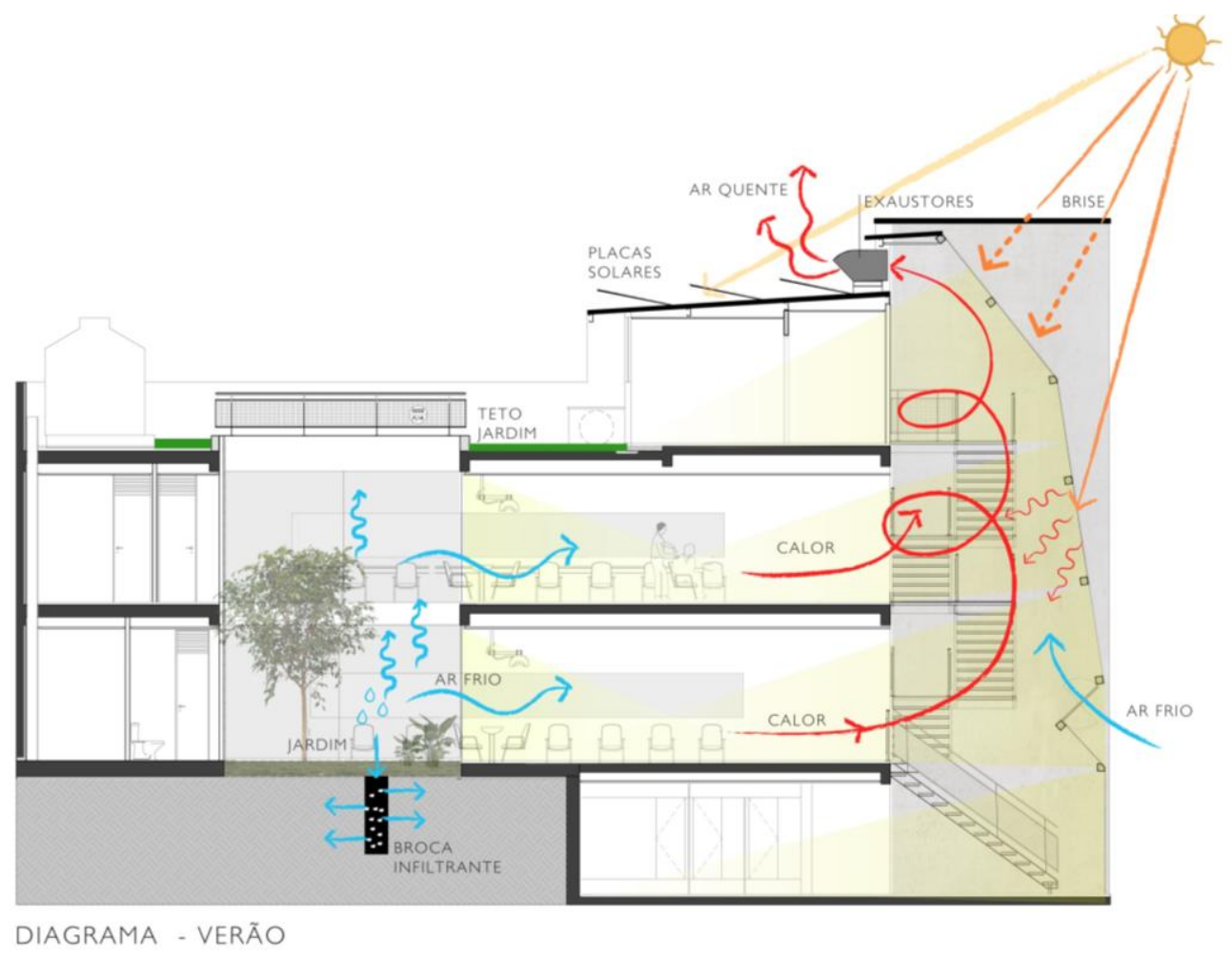

Fig.136 - Diagrama verão Edifício Comercial, São Paulo Fonte: acervo pessoal do arquiteto 


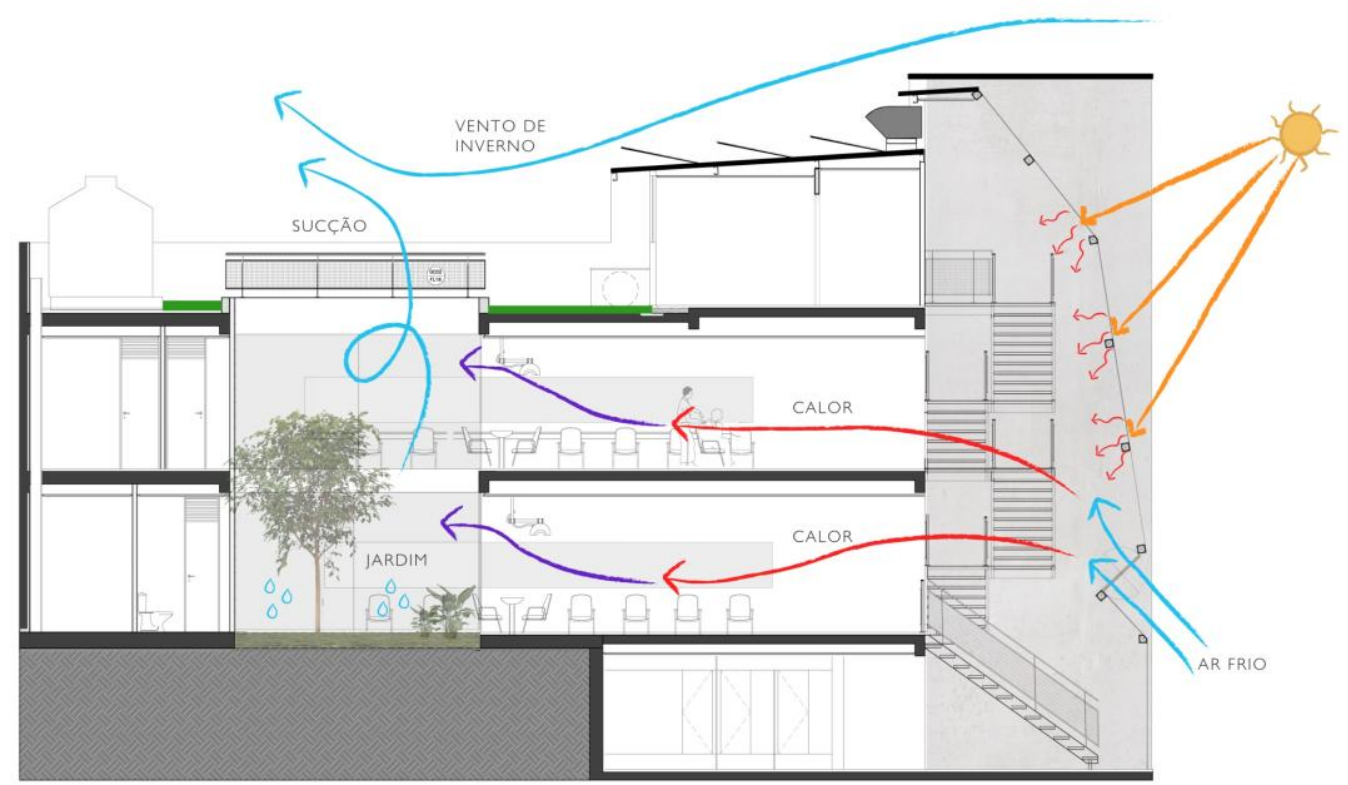

DIAGRAMA - INVERNO

Fig.137 - Diagrama inverno Edifício Comercial, São Paulo Fonte: acervo pessoal do arquiteto

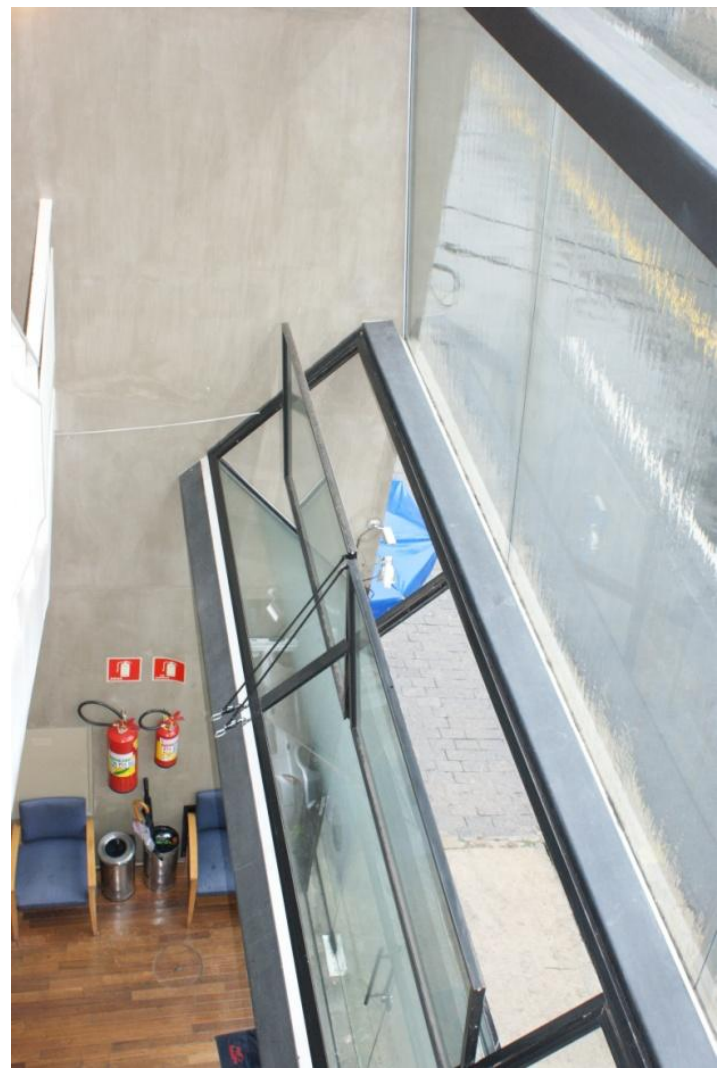

Fig.138-Edifício Comercial, São Paulo Fonte: acervo pessoal da autora 
“Mas como recebemos a comoção arquitetônica? Pelo efeito das relações que percebemos. O que propicia tais relações? As coisas, as superfícies que vemos. Nós as vemos porque são iluminadas e, ainda mais, a luz do sol age sobre o animal humano com uma eficácia enraizada no próprio âmago da espécie”.

(LE CORBUSIER, 2004, p.83)

\section{CONSIDERAÇÕES FINAIS}

Os arquitetos aqui analisados pertencem a uma geração que valoriza a continuidade na arquitetura mas com um olhar crítico sobre a tradição do moderno. Em seus discursos percebe-se a herança do modernismo. A defesa do meio ambiente e do patrimônio histórico e cultural e a recuperação das áreas de degradação das cidades revelam-se como preocupações e responsabilidades a serem assumidas em seus cotidianos profissionais.

Percebe-se, que os arquitetos, focos do trabalho, não apenas assumiram a herança do Modernismo, como também, de maneira muito contundente, o legado dos conteúdos acadêmicos. A matriz principal da arquitetura produzida por esses jovens arquitetos é o Modernismo, mas com a percepção e posterior incorporação das críticas e reflexões feitas ao movimento.

Cavalcanti (2005, p.19) refere-se aos arquitetos contemporâneos brasileiros, dizendo:

"A nova geração de arquitetos apresenta uma clara influência e inspiração nos projetos modernistas "históricos" brasileiros dos anos 1940 e 1950 - período mais profícuo e de maior reconhecimento internacional. Uma vez descartadas as ilusões do papel de transformação social do país através da arquitetura, o moderno é tomado como linguagem e não mais como ideologia. Sob certo aspecto, os profissionais de hoje citam elementos da gramática modernista assim como os pósmodernistas citavam elementos de estilos pretéritos, gótico, românico ou neoclássico. Não se trata, contudo, de ironia, retomada decorativa ou de uma postura nostálgica. Após duas décadas extremamente difíceis na economia do país, a arquitetura brasileira parece retomar o seu impulso e rumo inovador. Construída hoje sem a iniciativa maciça do Estado, os projetos mais interessantes são feitos em pequena escala para clientes particulares. O moderno serve de referência para que se possa voltar a avançar na linguagem arquitetônica e estrutural. É perceptível na produção atual a filiação a posturas e linhagens que tiveram suas matrizes e prédios paradigmáticos lançados pela primeira geração de modernistas brasileiros. 
Como se os arquitetos contemporâneos utilizassem o precioso legado modernista para voltar a atingir uma expressão inconfundivelmente brasileira, cosmopolita e internacional".

Segre $(2005$, p.26) compartilha da mesma opinião que Cavalcanti com relação aos arquitetos contemporâneos:

\footnotetext{
"Sintetizando algumas características dos arquitetos jovens, cabe assinalar que essa geração se libertou da influência direta dos mestres consagrados, não acreditam mais na teoria das escolas regionais e não se ofuscam com as modas internacionais do "star system". Em uma produção essencialmente caracterizada por temas de pequeno porte inseridos no contexto urbano, a temática "regionalista" e a expressão formalista da "brasilidade" assumem uma importância menor. Essa nova geração assume com seriedade a herança do Modernismo heróico dos anos 30 nos seus conteúdos éticos, construtivos e funcionais, na adaptação ao clima e uso livre de materiais tradicionais ou de alta tecnologia. Busca uma resposta aos modos de viver e à cultura local, esquecendo o discurso utópico sobre um futuro desconhecido e inacessível. Surge, assim, uma arquitetura "realista", quase neutra, composta de elementos formais e espaciais elementares, mas articulados nas novas geometrias e nos princípios dinâmicos e interativos que caracterizam a contemporaneidade".
}

Os profissionais mostram em sua atividade profissional, cada um à sua maneira, o quanto a luz do dia pode ser utilizada como elemento de composição em arquitetura e como ela pode ser definidora do partido arquitetônico. A visão individual de cada arquiteto da luz do dia enquanto elemento de composição na arquitetura é concretizada e materializada em seus edifícios.

As obras analisadas revelam algumas similaridades quanto às soluções adotadas pelos arquitetos na captação da luz do dia para o interior do edifício. O pátio interno como condutor de luz para os ambientes internos é o elemento arquitetônico recorrente no Edifício Sede do SEBRAE, na Escola Estadual Jornalista Roberto Marinho, no Centro de Saúde, na Residência no Jardim América e também para o Edifício Comercial em São Paulo. Com exceção do Terminal da Lapa, onde a iluminação natural se deu principalmente através de aberturas zenitais, nas demais obras, a penetração da luz do dia nos edifícios ocorre através de aberturas laterais com a utilização constante de proteções externas - brise-soleil. 
Álvaro Puntoni utiliza a luz do dia enquanto elemento de composição na arquitetura de maneira pragmática. O seu trabalho enfatiza a aplicação das ideias relativas à utilização da luz do dia no espaço construído e como resultado, as consequências práticas desses conceitos. Em seus edifícios percebe-se que o sentido do aproveitamento da luz do dia está relacionado ao efeito prático dessa luz decorrente no espaço construído. Suas obras caracterizam-se por espaços intensamente iluminados, permitindo ao observador a percepção do todo e de seus componentes. A luz do dia revela aspectos importantes da qualidade do espaço e das intenções de projeto, pré-definidas pelo arquiteto.

O arquiteto Luciano Margotto Soares tem uma visão poética da luz do dia. Para ele, a luz do dia é um elemento inspirador em seu processo de projeto, representando, ao mesmo tempo um dos materiais componentes da arquitetura e também um vetor de percepção do espaço. Percebe-se que, em seus edifícios, a luz do dia estabelece o ambiente arquitetônico, atraindo a atenção do observador para alguns componentes do espaço, deixando outros elementos sob a sombra. Luz e sombra articulando espaços.

Para os arquitetos do escritório Andrade Morettin a luz do dia deve ser concebida em projeto e executada, objetivando uma maior eficácia nas funções que lhes são próprias e atendendo às necessidades para as quais foi projetada. A luz do dia assume um papel funcional. O seu desempenho deve corresponder às premissas do projeto e contribuir para a qualidade do espaço construído.

A postura inquisitiva do arquiteto Caio Faggin em sua prática projetual, leva a uma constante busca por melhores resultados na utilização da luz do dia. Em seus edifícios ela tem como função primordial revelar a arquitetura e a vivência do edifício.

Os arquitetos do escritório FGMF também apresentam uma visão pragmática da luz do dia. Assim como outros elementos conformadores do espaço, em suas obras ela recebe um tratamento prático, não dogmático.

No processo projetual dos arquitetos foco deste trabalho, a luz do dia é incorporada seja através de gestos precisos que afirmam ou negam a sua existência em planos, superfícies e no vazio; através de reflexões que a transformam em verdadeira poesia nos edifícios e através de seu desempenho e contribuição à qualidade do espaço construído. 
APÊNDICE 


\section{ROTEIRO DE ENTREVISTA DOS ARQUITETOS}

1 - Nome e Formação?

2 - Como foi a sua formação acadêmica na FAUUSP?

3 - Como aconteciam as aulas de Projeto no atelier?

4 - Qual a sua opinião sobre a relação luz natural e arquitetura?

5 - Qual a importância da luz natural enquanto elemento de composição da arquitetura?

6 - Retornando à sua formação acadêmica, como foi o aprendizado da luz natural na escola?

7 - Havia algum tipo de integração/intercambio de informações/atividades entre os professores de projeto e os professores de conforto, mais especificamente de iluminação, nas aulas de atelier?

8 - Nas aulas de projeto os alunos eram cobrados quanto ao lançamento de um partido estrutural ou até mesmo quanto à definição de um material. Existia algum tipo de cobrança por parte dos professores, com relação à iluminação natural do edifício projetado?

9 - Qual a sua opinião sobre colocar o ensino teórico da arquitetura - história e tecnologia a serviço do atelier de projetos?

10 - Profissionalmente, como é feita a abordagem da luz natural em seus trabalhos?

11 - Em seus projetos, podemos dizer que a luz natural pode ser um dos elementos a definir o partido arquitetônico? 
12 - Em sua opinião, qual dos seus projetos é o mais significativo quanto à utilização da luz natural enquanto protagonista do partido arquitetônico? E por quê?

13 - Quais os recursos que são utilizados em seus projetos para a análise da luz natural? Modelo em escala reduzida, simulador?

14 - Quais arquitetos, em sua opinião, trabalham e/ou trabalharam a luz natural como matéria prima de composição? 
BRANDSTON, Howard M. Learning to see. A matter of light. USA: Illuminating Society of North America, 2008.

CHEVALIER, Jean; GHEERBRANT, Alain. Dicionário de símbolos. Mitos, sonhos, costumes, gestos, formas, figuras, cores, números. 5a ed. Rio de Janeiro: José Olympio Editora, 1991.

ELIADE, Mircea. O sagrado e o profano. 1a ed. São Paulo: Martins Fontes, 1992.

GUZOWSKI, Mary. Daylighting for sustainable design. New York: McGraw-Hill, 1999.

KAHN, Louis; BROWNLEE, David B.; DE LONG, David. Louis Kahn: in the realm of architecture. London: Thames and Hudson, 1997.

LE CORBUSIER. Precisões sobre um estado presente da arquitetura e do urbanismo. São Paulo: Cosac \& Naify, 2004.

LURKER, Manfred. Dicionário de Simbologia. 2a ed. São Paulo: Martins Fontes, 2003.

MAJOR, Mark; SPEIRS, Jonathan; TISCHHAUSER, Anthony. Made of light. The art of light and architecture. Germany: Birkhauser, 2005.

MICHEL, Lou. Light: the shape of space. New York: John Wiley \& Sons, Inc., 1996.

MILHEIRO, Ana Vaz; NOBRE, Ana Luiza; WISNIK, Guilherme. Coletivo. 36 projetos de arquitetura paulista contemporânea. São Paulo: Cosac Naify, 2006.

MILLET, Marietta S. Light revealing architecture. New Jersey: John Wiley \& Sons, Inc., 1996.

MOORE, Fuller. Concepts and practice of architectural daylighting. New York: Van Nostrand Reinhold Company Inc., 1985.

PALLASMAA, Juhani. The eyes of the skin. Architecture and the senses. England: John Wiley \& Sons Ltd., 2005.

PLUMMER, Henry. Poetics of Light. Extra edition. Tokyo: a+u Publishing Co.Ltd., 1987.

PLUMMER, Henry. Light in Japanese Architecture. Extra edition. Tokyo: a+u Publishing Co.Ltd., 1995.

PLUMMER, Henry. : La arquitectura de la luz natural. Barcelona: Blume, 2009.

QUINTANA, Mário. Da preguiça como método de trabalho. 2a ed. Rio de Janeiro: Globo, 1987. 
REITER, Sigrid; HERDE André de. L' éclairage naturel des bâtiments. Louvain-la-Neuve, Belgique: Presses universitaires de Louvain, 2004.

ROBBINS, Claude L. Daylighting: design and analysis. New York: Van Nostrand Reinhold Company Inc., 1996.

SCHMID, Aloísio Leoni. A idéia de conforto: reflexões sobre o ambiente construído. Curitiba: Pacto Ambiental, 2005.

SOARES, Luciano Margotto. A arquitetura de Álvaro Siza: três estudos de caso. 2001. Dissertação de Mestrado - Programa de Pós-Graduação em Arquitetura e Urbanismo da FAUUSP, São Paulo.

SZABO, Ladislao Pedro. Visões de luz. O pensamento de arquitetos modernistas sobre o uso da luz na arquitetura. 1995. Dissertação de Mestrado - Programa de Pós-Graduação em Arquitetura e Urbanismo da Universidade Mackenzie, São Paulo.

URSINI, Marcelo Luiz. Entre o público e o privado: os espaços francos na Avenida Paulista. 2004. Dissertação de Mestrado - Programa de Pós-Graduação em Arquitetura e Urbanismo da FAUUSP, São Paulo.

VENTURI, Robert. Complexidade e contradição em arquitetura. 2a Edição. Martins Fontes: São Paulo, 2004.

DIAS, Solange Irene Smolarek. Bakhtin: signos, polifonia e interpretação do discurso. Semiótica e arquitetura. II ENTEX - Encontro de pesquisa e extensão - UNIOESTE. Cascavel: 2004.

Disponível em:

http://www.fag.edu.br/professores/solange/PRODUCAO\%20CIENTIFICA/II\%20ENTEX\%20\%20UNIOSTE\%20-\%20CVEL/ARTIGO\%20-\%20II\%20ENTEX\%20-\%20UNIOESTE.pdf Acesso em: 20 fev. 2012.

DAVIES, Jonathan. Arquitetos do Futuro. aU, São Paulo, ano 25, n.197, p.49, agosto 2010. Entrevista concedida a Bianca Antunes e Murício Horta.

PUNTONI, Álvaro. Rigor, austeridade, criatividade. aU, São Paulo, ano 24, n.183, p.60-63, junho 2009. Entrevista concedida a Éride Moura.

PUNTONI, Álvaro. Desconstruindo muros imaginários. aU, São Paulo, ano 23, n.172, julho 2008.

SEGRE, Roberto. O eterno vazio e realidade na arquitetura brasileira. aU, São Paulo, n.137, p. 24, ago. 2005. 
O regionalismo está com os dias contados? aU, São Paulo, ano 24, n. 178, janeiro 2009.

Lighting design: principles, implementation, case studies. Detail Practice. Munich, 2006.

ZANETTINI, Siegbert. Arquitetura deve ser holística e sistêmica. Finestra, São Paulo, ed.47, dez. 2006.

ANELLI, Renato. Tênue transparência. Revista Monolito, São Paulo, ed. 2, abril/maio 2011.

CAVALCANTI, L.; LAGO, A.C. Ainda moderno? Arquitetura brasileira contemporânea. Vitruvius, nov. 2005.

Disponível em <http://www.vitruvius.com.br/arquitextos/arq066/arq066_00.asp>.

Acesso em: 27 jul. 2009.

GRINBERG, Sara Topelson de. Arquiteto Abraham Zabludovsky (1924-2003). Vitruvius, maio 2003.

Disponível em: http://vitruvius.com.br/revistas/read/arquitextos/03.036/686/pt

Acesso em: 05 mai. 2011.

REIS-ALVES, Luiz Augusto. O que é o pátio interno? parte 2. Vitruvius, setembro 2005.

Disponível em: www.vitruvius.com.br/revistas/read/arquitextos/06.064/425

Acesso em: 12 nov. 2011.

http://www.andrademorettin.com.br

Acesso em: 03 jan. 2012.

http://www.archdaily.com.br/15140/residencia-rr-andrade-morettin-arquitetosassociados/andrademorettin_rr_montagem_09-copy/

Acesso em: 03 jan. 2012.

http://www.arcoweb.com.br/artiart/fernando-serapiao-rino-levi-02-01-2002.html Acesso em: 03 jan. 2012.

http://www.arcoweb.com.br/entrevista/sidonio-porto-o-arquiteto-07-05-2010.html Acesso em: 03 jan. 2012.

http://www.constructalia.com/portugues_br/galeria_de_projetos

Acesso em: 03 jan. 2012.

http://www.editoramonolito.com.br/edicoes/02/

Acesso em: 03 jan. 2012.

http://www.vitruvius.com.br/revistas/read/projetos/05.057/2529?page=10

Acesso em: 03 jan. 2012. 
http:www.googleearth.com.br Acesso em 22 jun. 2011.

http:www2.nelsonkon.com.br acesso em 22 jun. 2011. 